National Water-Quality Assessment Program

\title{
Trends in Streamflow and Nutrient and Suspended-Sediment Concentrations and Loads in the Upper Mississippi, Ohio, Red, and Great Lakes River Basins, 1975-2004
}

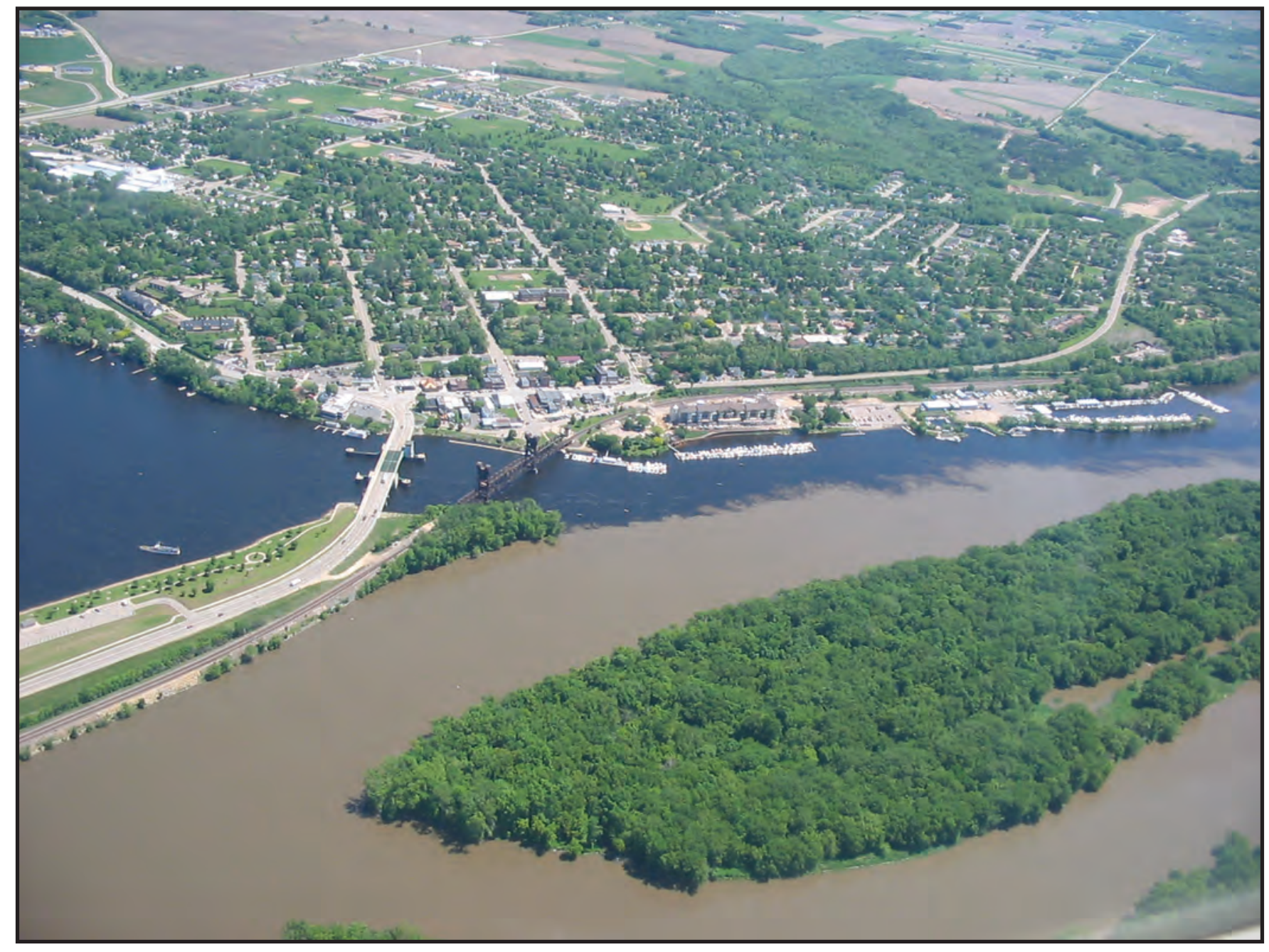

Scientific Investigations Report 2008-5213 
Cover: Contrast in sediment loads in the Mississippi and St. Croix Rivers at their confluence. (Photograph by David Morrison, Minnesota Pollution Control Agency.) 


\section{Trends in Streamflow and Nutrient and Suspended-Sediment Concentrations and Loads in the Upper Mississippi, Ohio, Red, and Great Lakes River Basins, 1975-2004}

By David L. Lorenz, Dale M. Robertson, David W. Hall, and David A. Saad

National Water-Quality Assessment Program

Scientific Investigations Report 2008-5213

U.S. Department of the Interior

U.S. Geological Survey 


\section{U.S. Department of the Interior \\ KEN SALAZAR, Secretary \\ U.S. Geological Survey \\ Suzette M. Kimball, Acting Director}

U.S. Geological Survey, Reston, Virginia: 2009

For more information on the USGS—-the Federal source for science about the Earth, its natural and living resources,
natural hazards, and the environment, visit http://www.usgs.gov or call 1-888-ASK-USGS
For an overview of USGS information products, including maps, imagery, and publications,
visit http://www.usgs.gov/pubprod
To order this and other USGS information products, visit http://store.usgs.gov

Any use of trade, product, or firm names is for descriptive purposes only and does not imply endorsement by the U.S. Government.

Although this report is in the public domain, permission must be secured from the individual copyright owners to reproduce any copyrighted materials contained within this report.

Suggested citation:

Lorenz, D.L., Robertson, D.M., Hall, D.W., and Saad, D.A., 2009, Trends in streamflow and nutrient and suspendedsediment concentrations and loads in the Upper Mississippi, Ohio, Red, and Great Lakes River Basins, 1975-2004: U.S. Geological Survey Scientific Investigations Report 2008-5213, 81 p. 


\section{Foreword}

The U.S. Geological Survey (USGS) is committed to providing the Nation with credible scientific information that helps to enhance and protect the overall quality of life and that facilitates effective management of water, biological, energy, and mineral resources (http://www.usgs.gov/). Information on the Nation's water resources is critical to ensuring long-term availability of water that is safe for drinking and recreation and is suitable for industry, irrigation, and fish and wildlife. Population growth and increasing demands for water make the availability of that water, now measured in terms of quantity and quality, even more essential to the longterm sustainability of our communities and ecosystems.

The USGS implemented the National Water-Quality Assessment (NAWQA) Program in 1991 to support national, regional, State, and local information needs and decisions related to water-quality management and policy (http://water.usgs.gov/nawqa). The NAWQA Program is designed to answer: What is the condition of our Nation's streams and groundwater? How are conditions changing over time? How do natural features and human activities affect the quality of streams and groundwater, and where are those effects most pronounced? By combining information on water chemistry, physical characteristics, stream habitat, and aquatic life, the NAWQA Program aims to provide science-based insights for current and emerging water issues and priorities. From 1991-2001, the NAWQA Program completed interdisciplinary assessments and established a baseline understanding of water-quality conditions in 51 of the Nation's river basins and aquifers, referred to as Study Units (http://water.usgs.gov/nawqa/studyu.html).

In the second decade of the Program (2001-2012), a major focus is on regional assessments of waterquality conditions and trends. These regional assessments are based on major river basins and principal aquifers, which encompass larger regions of the country than the Study Units. Regional assessments extend the findings in the Study Units by filling critical gaps in characterizing the quality of surface water and groundwater, and by determining status and trends at sites that have been consistently monitored for more than a decade. In addition, the regional assessments continue to build an understanding of how natural features and human activities affect water quality. Many of the regional assessments employ modeling and other scientific tools, developed on the basis of data collected at individual sites, to help extend knowledge of water quality to unmonitored, yet comparable areas within the regions. The models thereby enhance the value of our existing data and our understanding of the hydrologic system. In addition, the models are useful in evaluating various resource-management scenarios and in predicting how our actions, such as reducing or managing nonpoint and point sources of contamination, land conversion, and altering flow and (or) pumping regimes, are likely to affect water conditions within a region.

Other activities planned during the second decade include continuing national syntheses of information on pesticides, volatile organic compounds (VOCs), nutrients, selected trace elements, and aquatic ecology; and continuing national topical studies on the fate of agricultural chemicals, effects of urbanization on stream ecosystems, bioaccumulation of mercury in stream ecosystems, effects of nutrient enrichment on stream ecosystems, and transport of contaminants to public-supply wells.

The USGS aims to disseminate credible, timely, and relevant science information to address practical and effective water-resource management and strategies that protect and restore water quality. We hope this NAWQA publication will provide you with insights and information to meet your needs, and will foster increased citizen awareness and involvement in the protection and restoration of our Nation's waters.

The USGS recognizes that a national assessment by a single program cannot address all water-resource issues of interest. External coordination at all levels is critical for cost-effective management, regulation, and conservation of our Nation's water resources. The NAWQA Program, therefore, depends on advice and information from other agencies - Federal, State, regional, interstate, Tribal, and local-as well as nongovernmental organizations, industry, academia, and other stakeholder groups. Your assistance and suggestions are greatly appreciated.

Matthew C. Larsen

Associate Director for Water 


\section{Contents}

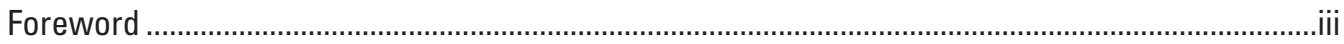

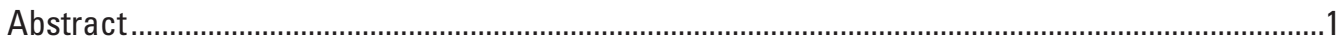

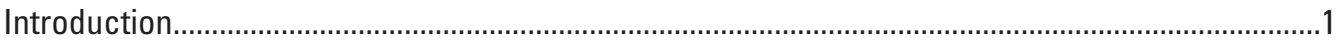

Study Area and Environmental Setting ……...............................................................................

Factors Affecting Nutrient and Suspended-Sediment Concentrations and Loads ...................3

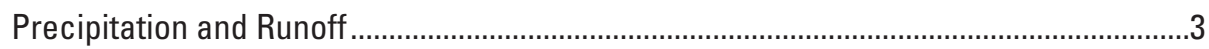

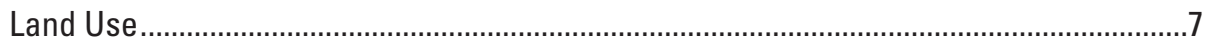

Fertilizers and Manure …………………………….............................................

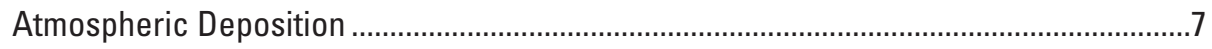

Total Nonpoint Sources of Nutrients ...........................................................................13

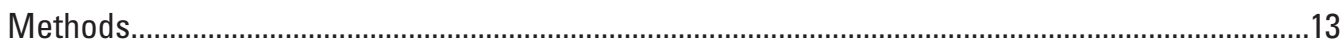

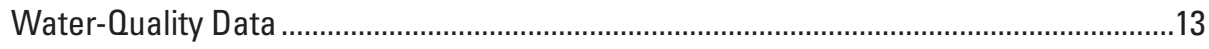

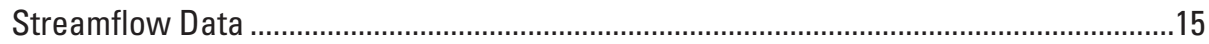

Final Site and Sample Selection...................................................................................

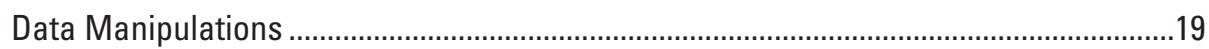

Basin Boundaries and Land-Use Classification ............................................................20

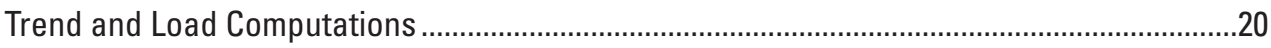

Computation of Loads for General Spatial Patterns .......................................................21

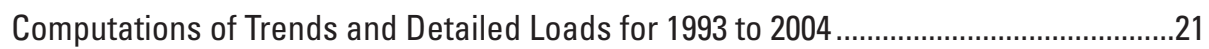

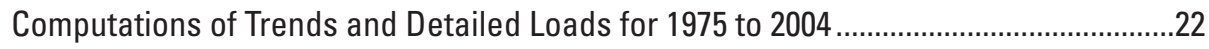

Explanation of Observed Trends....................................................................................23

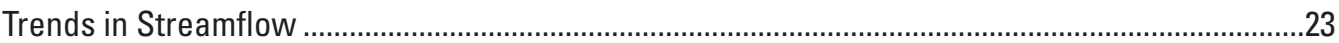

Trends in Nutrient and Suspended-Sediment Concentrations and Loads.....................................26

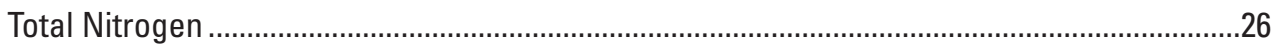

General Patterns in Total Nitrogen Concentrations and Yields ......................................26

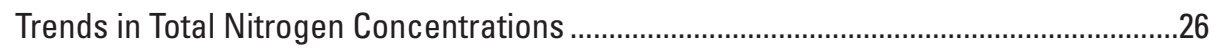

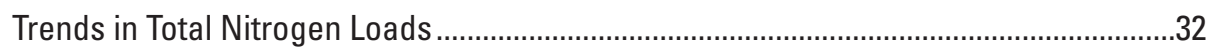

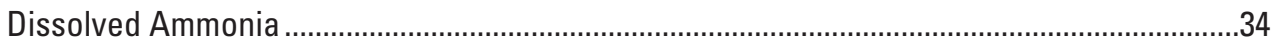

General Patterns in Dissolved Ammonia Concentrations and Yields ...............................34

Trends in Dissolved Ammonia Concentrations .................................................................34

Trends in Dissolved Ammonia Loads..............................................................................34

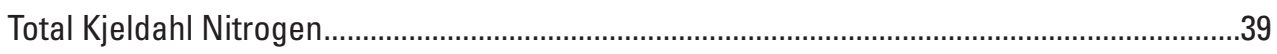

General Patterns in Total Kjeldahl Nitrogen Concentrations and Yields.........................39

Trends in Total Kjeldahl Nitrogen Concentrations.........................................................39

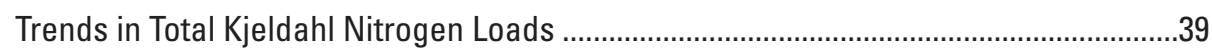

Dissolved Nitrite plus Nitrate Nitrogen .................................................................................39

General Patterns in Dissolved Nitrite plus Nitrate Nitrogen Concentrations

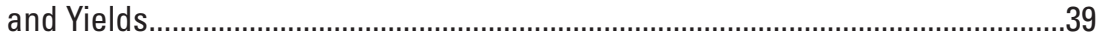

Trends in Dissolved Nitrite plus Nitrate Nitrogen Concentrations .................................39

Trends in Dissolved Nitrite plus Nitrate Loads............................................................ 


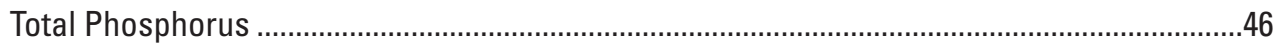

General Patterns in Total Phosphorus Concentrations and Yields.................................46

Trends in Total Phosphorus Concentrations ...............................................................

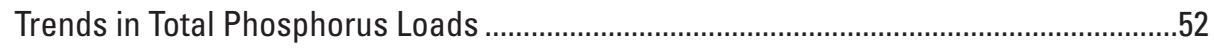

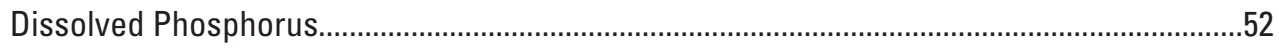

General Patterns in Dissolved Phosphorus Concentrations and Yields.........................52

Trends in Dissolved Phosphorus Concentrations...........................................................56

Trends in Dissolved Phosphorus Loads ...................................................................56

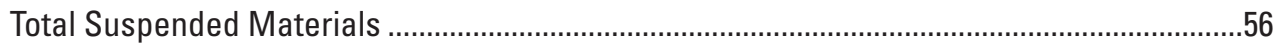

General Patterns in Concentrations and Yields of Total Suspended Materials ..............56

Trends in Total Suspended-Material Concentrations ....................................................56

Trends in Total Suspended-Material Loads.................................................................62

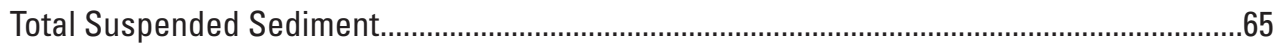

Trends in Total Suspended-Sediment Concentrations ....................................................65

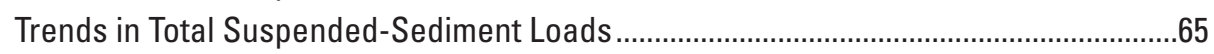

Understanding Water-Quality Trends in the Context of Human Activity ..........................................65

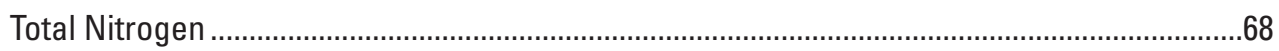

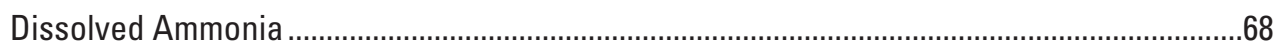

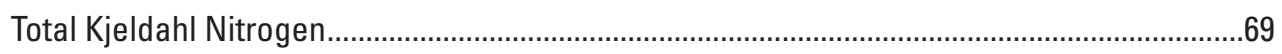

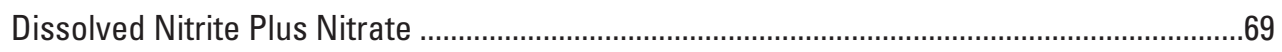

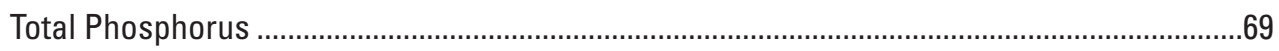

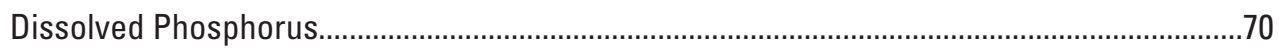

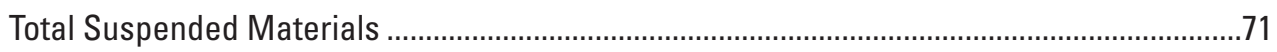

Changes in Loads from 1993 to 2004 in a Longer Term Context .......................................................71

Understanding Trends in Loads in the Context of Climatic Variability .............................................72

Comparison between Nutrient Loads from This Study and Loads Contributing to the

Gulf of Mexico Hypoxic Zone ........................................................................................

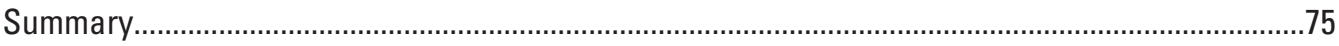

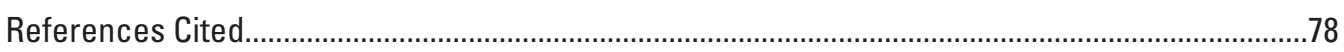

\section{Figures}

1-3. Maps showing:

1. Study area, major river basins, and sites .................................................................

2. Average annual precipitation across the study area, 1971 to $2000 \ldots \ldots \ldots \ldots \ldots \ldots \ldots \ldots \ldots \ldots . . .5$

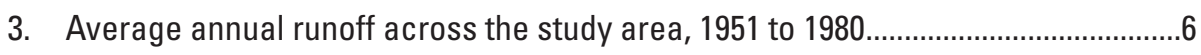

4. Graph showing annual precipitation from 1975 to 2005 at five sites in the study area.....6

5-12. Maps showing:

5. Land use and land cover across the study area, with the 10 largest metropolitan areas identified...

6. Study area population by county in 2000 and county-level change from 1990 to 2000 ...

7. Fertilizer nitrogen application by county in 1997 and changes in application rates from 1993 to 2004 for nitrogen and phosphorus 
8. Manure nitrogen application rates by county in 1997 and changes in application rates from 1992 to 2002 for nitrogen and phosphorus ..

9. Rates of atmospheric deposition of nitrogen by county in 1997 and changes in atmospheric deposition rates from 1993 to 2004

10. Total annual input rates of nitrogen from nonpoint sources (fertilizers, manure, and atmospheric deposition) by county in 1997 and changes in the total input rates from 1993 to 2004 for nitrogen and phosphorus; atmospheric deposition of phosphorus was assumed to be negligible.

11. Sites used in the study

12. Trends in streamflow from 1993 to 2004 throughout the study area

13. Graphs showing long-term trends in streamflow from 1975 to 2003 at six selected sites in the study area.

14. Maps showing spatial patterns from 1970 to 2004 in median total nitrogen concentrations and median annual total nitrogen yields throughout the study area .

15. Maps showing trends in total nitrogen from 1993 to 2004 for flow-adjusted concentrations, overall concentrations, and annual loads throughout the study area .

16. Graphs showing long-term flow-adjusted trends in total nitrogen concentrations from 1975 to 2004 at six selected sites in the study area....

17. Graphs showing long-term trends in total nitrogen loads from 1975 to 2003 at six selected sites in the study area

18-22. Maps showing:

18. Trends in dissolved ammonia from 1993 to 2004 for flow-adjusted concentrations, overall concentrations, and annual loads throughout the study area.

19. Trends in total Kjeldahl nitrogen from 1993 to 2004 for flow-adjusted concentrations, overall concentrations, and annual loads throughout the study area.

20. Trends in dissolved nitrite plus nitrate from 1993 to 2004 for flow-adjusted concentrations, overall concentrations, and annual loads throughout the study area.

21. Spatial patterns from 1970 to 2004 in median total phosphorus concentrations and median annual total phosphorus yields throughout the study area.

22. Trends in total phosphorus from 1993 to 2004 for flow-adjusted concentrations, overall concentrations, and annual loads throughout the study area.

23. Graphs showing long-term flow-adjusted trends in total phosphorus concentrations from 1975 to 2004 at six selected sites in the study area.

24. Graphs showing long-term trends in total phosphorus loads from 1975 to 2003 at six selected sites in the study area......

25-27. Maps showing:

25. Trends in dissolved phosphorus from 1993 to 2004 for flow-adjusted concentrations, overall concentrations, and annual loads throughout the study area.

26. Spatial patterns from 1970 to 2004 in median total suspended-material concentrations and median annual total suspended-material yields throughout the study area.. 
27. Trends in total suspended materials from 1993 to 2004 for flow-adjusted concentrations, overall concentrations, and annual loads throughout the study area.

28-32. Graphs showing:

28. Long-term flow-adjusted trends in total suspended-material concentrations from 1975 to 2004 at six selected long-term sites

29. Long-term trends in total suspended-material loads from 1975 to 2003 at six sites in the study area.

30. Trends in total suspended sediment from 1993 to 2004 for flow-adjusted concentrations, overall concentrations, and annual loads throughout the study area

31. Relation between trends in flow-adjusted dissolved phosphorus concentrations and trends in phosphorus inputs from farm fertilizers for sites with varying types of land use in the basin, 1993 to 2004

32. Total annual nitrogen and phosphorus loads at the Mississippi River at Clinton, lowa (site with the largest drainage area in this study) and from the entire Mississippi/Atchafalaya River (MAR) Basin from 1975 to 2005 as estimated in this study and by Aulenbach and others (2007).

\section{Tables}

1. Description of sites used in trend analyses.

2. Adjustments applied to censored data values retrieved from the National Water Quality Laboratory.

3. Nine predefined regression models for estimating loads

4. Summary of results for analyses of trends in streamflow at selected sites in the study area, 1993 to 2004

5. Summary of results for analyses of flow-adjusted trends, overall trends, and trends in loads for total nitrogen (TN, USGS parameter code 00600), 1993 to 2004

6. Summary of flow-adjusted trends in total nitrogen concentrations (TN, USGS parameter code 00600) estimated by OWTREND for long-term evaluation sites, 1975 to 2004

7. Summary of results for analyses of flow-adjusted trends, overall trends, and trends in loads for dissolved ammonia (NH4, USGS parameter code 00608), 1933 to 2004

8. Summary of results for analyses of flow-adjusted trends, overall trends, and trends in loads for total Kjeldahl nitrogen (KJN, USGS parameter code 00625), 1993 to 2004

9. Summary of results for analyses of flow-adjusted trends, overall trends, and trends in loads for dissolved nitrite plus nitrate nitrogen (NO3, USGS parameter code 00631), 1993 to 2004 ...

10. Summary of results for analyses of flow-adjusted trends, overall trends, and trends in loads for total phosphorus (TP, USGS parameter code 00665), 1993 to 2004

11. Summary of flow-adjusted trends in total phosphorus concentrations (TP, USGS parameter code 00665) estimated by QWTREND for long-term evaluation sites, 1975 to 2004 
12. Summary of results for analyses of flow-adjusted trends, overall trends, and trends in loads for dissolved phosphorus (DP, USGS parameter code 00666), 1993 to 2004

13. Summary of results for analyses of flow-adjusted trends, overall trends, and trends in loads for total suspended material (SMAT, USGS parameter codes 80154 and 00530 combined), 1993 to 2004.

14. Summary of flow-adjusted trends in total suspended-material concentrations estimated by QWTREND for long-term evaluation sites, 1975 to 2004 ...

15. Summary of results for analyses of flow-adjusted trends, overall trends, and trends in loads for total suspended sediment (SS, USGS parameter code 80154$), 1993$ to 2004

\section{Conversion Factors and Datum}

\begin{tabular}{lcl}
\hline \multicolumn{1}{c}{ Multiply } & \multicolumn{1}{c}{ By } & \multicolumn{1}{c}{ To obtain } \\
\hline & Length & \\
\hline centimeter $(\mathrm{cm})$ & 0.3937 & inch (in.) \\
meter $(\mathrm{m})$ & 3.281 & foot $(\mathrm{ft})$ \\
meter $(\mathrm{m})$ & 1.094 & yard $(\mathrm{yd})$ \\
kilometer $(\mathrm{km})$ & 0.6214 & mile $(\mathrm{mi})$ \\
kilometer $(\mathrm{km})$ & 0.5400 & mile, nautical $(\mathrm{nmi})$ \\
\hline & Area & \\
\hline square kilometer $\left(\mathrm{km}^{2}\right)$ & 247.1 & acre \\
square kilometer $\left(\mathrm{km}^{2}\right)$ & 0.3861 & square mile $\left(\mathrm{mi}^{2}\right)$ \\
\hline & Volume & \\
\hline cubic meter $\left(\mathrm{m}^{3}\right)$ & 35.31 & cubic foot $\left(\mathrm{ft}^{3}\right)$ \\
cubic meter $\left(\mathrm{m}^{3}\right)$ & 1.308 & cubic yard $\left(\mathrm{yd} \mathrm{d}^{3}\right)$ \\
\hline & Flow rate & \\
\hline cubic meter per second $\left(\mathrm{m}^{3} / \mathrm{s}\right)$ & 22.83 & million gallons per day $(\mathrm{Mgal} / \mathrm{d})$ \\
cubic meter per second $\left(\mathrm{m}^{3} / \mathrm{s}\right)$ & 70.07 & acre-foot per day $(\mathrm{acre}-\mathrm{ft} / \mathrm{d})$ \\
cubic meter per second $\left(\mathrm{m}^{3} / \mathrm{s}\right)$ & 35.31 & cubic foot per second $\left(\mathrm{ft}^{3} / \mathrm{s}\right)$ \\
\hline & Mass & \\
\hline kilogram $(\mathrm{kg})$ & 2.205 & pound avoirdupois $(\mathrm{lb})$ \\
kilogram per year $(\mathrm{kg} / \mathrm{yr})$ & 2.205 & pound per year $(\mathrm{lb} / \mathrm{yr})$ \\
\hline & Application rate & \\
\hline kilograms per square kilometer $\left(\mathrm{kg} / \mathrm{km}^{2}\right)$ & 0.8514 & pounds per square mile $\left(\mathrm{lb} / \mathrm{mi}^{2}\right)$ \\
\hline
\end{tabular}

Horizontal coordinate information is referenced to the North American Datum of 1983 (NAD83).

Concentrations of chemical constituents in water are given either in milligrams per liter ( $\mathrm{mg} / \mathrm{L})$ or micrograms per liter $(\mu \mathrm{g} / \mathrm{L})$.

Water year is the 12-month period, 0 ctober 1 through September 30, and is designated by the calendar year in which it ends. Thus, the water year ending September 30, 2003 is called "water year 2003." 


\section{Abbreviations used in report}

\begin{tabular}{|c|c|}
\hline Abbreviation & Description \\
\hline \multicolumn{2}{|r|}{ River basins } \\
\hline GL & Great Lakes \\
\hline MAR & Mississippi-Atchafalaya River \\
\hline $\mathrm{OH}$ & Ohio River, exclusive of the Tennessee River \\
\hline RR & Red River including the Red, Rainy, and Souris Rivers \\
\hline $\mathrm{UM}$ & $\begin{array}{l}\text { Mississippi River upstream from confluence with the Ohio River, } \\
\text { exclusive of the Missouri River }\end{array}$ \\
\hline \multicolumn{2}{|r|}{ Constituents } \\
\hline DP & Dissolved phosphorus \\
\hline KJN & Total (whole water) organic plus ammonia nitrogen (Kjeldahl) \\
\hline NH4 & Dissolved ammonia \\
\hline $\mathrm{NO} 2 \mathrm{NO} 3$ & Dissolved nitrite plus nitrate \\
\hline SMAT & Total suspended material \\
\hline SS & Total suspended sediment \\
\hline $\mathrm{TN}$ & Total (whole water) nitrogen \\
\hline $\mathrm{TP}$ & Total (whole water) phosphorus \\
\hline \multicolumn{2}{|r|}{ Equation symbols } \\
\hline$\beta$ & estimated coefficient \\
\hline$C$ & log concentration \\
\hline$e$ & base of natural logarithms \\
\hline F & unit conversion factor \\
\hline FAC & $\log$ of the flow-adjusted concentration \\
\hline$H F V$ & high-frequency variability component \\
\hline$L$ & daily load \\
\hline$Q$ & log streamflow \\
\hline$Q^{a}$ & center value for streamflow \\
\hline$Q^{*}$ & centered log of streamflow \\
\hline$T^{m}$ & midpoint of the period of record \\
\hline$T^{a}$ & centering value of time \\
\hline$\% \triangle F A C / y r$ & percent change in flow-adjusted trend per year \\
\hline
\end{tabular}




\section{Abbreviations used in report—continued}

\begin{tabular}{ll}
\hline Abbreviation & \multicolumn{1}{c}{ Description } \\
\hline$<$ & \multicolumn{1}{c}{ Other abbreviations } \\
$\leq$ & less than \\
$>$ & less than or equal to \\
$\geq$ & greater than \\
AIC & greater than or equal to \\
CAFO & Akaike information criterion \\
FAC & confined animal feeding operations \\
FA trend & flow-adjusted concentration \\
MDL & flow-adjusted trend \\
NAWQA & method detection limit \\
NWIS & National Water-Quality Assessment \\
NWQL & National Water Information System \\
OA trend & National Water Quality Laboratory \\
QL & overall trend in concentration \\
USEPA & quantitation limit \\
USGS & U.S. Environmental Protection Agency \\
\hline
\end{tabular}




\title{
Trends in Streamflow and Nutrient and Suspended- Sediment Concentrations and Loads in the Upper Mississippi, Ohio, Red, and Great Lakes River Basins, 1975-2004
}

\author{
By David L. Lorenz, Dale M. Robertson, David W. Hall, and David A. Saad
}

\section{Abstract}

Many actions have been taken to reduce nutrient and suspended-sediment concentrations and the amount of nutrients and sediment transported in streams as a result of the Clean Water Act and subsequent regulations. This report assesses how nutrient and suspended-sediment concentrations and loads in selected streams have changed during recent years to determine if these actions have been successful.

Flow-adjusted and overall trends in concentrations and trends in loads from 1993 to 2004 were computed for total nitrogen, dissolved ammonia, total organic nitrogen plus ammonia, dissolved nitrite plus nitrate, total phosphorus, dissolved phosphorus, total suspended material (total suspended solids or suspended sediment), and total suspended sediment for 49 sites in the Upper Mississippi, Ohio, Red, and Great Lakes Basins. Changes in total nitrogen, total phosphorus, and total suspended-material loads were examined from 1975 to 2003 at six sites to provide a longer term context for the data examined from 1993 to 2004.

Flow-adjusted trends in total nitrogen concentrations at 19 of 24 sites showed tendency toward increasing concentrations, and overall trends in total nitrogen concentrations at 16 of the 24 sites showed a general tendency toward increasing concentrations. The trends in these flow-adjusted total nitrogen concentrations are related to the changes in fertilizer nitrogen applications. Flow-adjusted trends in dissolved ammonia concentrations from 1993 to 2004 showed a widespread tendency toward decreasing concentrations. The widespread, downward trends in dissolved ammonia concentrations indicate that some of the ammonia reduction goals of the Clean Water Act are being met. Flow-adjusted and overall trends in total organic plus ammonia nitrogen concentrations from 1993 to $2004 \mathrm{did}$ not show a distinct spatial pattern. Flow-adjusted and overall trends in dissolved nitrite plus nitrate concentrations from 1993 to 2004 also did not show a distinct spatial pattern.

Flow-adjusted trends in total phosphorus concentrations were upward at 24 of 40 sites. Overall trends in total phosphorus concentrations were mixed and showed no spatial pattern.
Flow-adjusted and overall trends in dissolved phosphorus concentrations were consistently downward at all of the sites in the eastern part of the basins studied. The reduction in phosphorus fertilizer use and manure production east of the Mississippi River could explain most of the observed trends in dissolved phosphorus.

Flow-adjusted trends in total suspended-material concentrations showed distinct spatial patterns of increasing tendencies throughout the western part of the basins studied and in Illinois and decreasing concentrations throughout most of Wisconsin, Iowa, and in the eastern part of the basins studied. Flow-adjusted trends in total phosphorus were strongly related to the flow-adjusted trends in suspended materials. The trends in the flow-adjusted suspended-sediment concentrations from 1993 to 2004 resembled those for suspended materials.

The long-term, nonmonotonic trends in total nitrogen, total phosphorus, and suspended-material loads for 1975 to 2003 were described by local regression, LOESS, smoothing for six sites. The statistical significance of those trends cannot be determined; however, the long-term changes found for annual streamflow and load data indicate that the monotonic trends from 1993 to 2004 should not be extrapolated backward in time.

\section{Introduction}

Elevated nutrient and suspended-sediment concentrations are the two of the most common contaminant stressors affecting streams throughout the United States (U.S. Environmental Protection Agency, 1996). Excessive nutrients in rivers and streams can result in the overgrowth of benthic algae in shallow areas and areas with fast current and in an overabundance of phytoplankton and macrophytes in deep areas with slow current. High algal and macrophyte biomass, in turn, can cause severe diurnal fluctuations in dissolved oxygen and $\mathrm{pH}$ because of biotic production and respiration. Very low dissolved oxygen concentrations often occur when part of the algal or macrophyte population dies and decomposes, which 
in turn can generate harmful organic materials (Welch and others, 1992). Therefore, high nutrient concentration conditions can lead to an increase in the availability of toxic substances, a decrease in available aquatic habitat, modifications to the composition of the biotic communities, and a decrease in the overall usefulness of the stream (Miltner and Rankin, 1998; Dodds and Welch, 2000). Excessive transport of nutrients has also been linked to eutrophication of downstream lakes and impoundments, outbreaks of Pfiesteria in bays and estuaries in various Gulf and Mid-Atlantic States, and hypoxia in the Gulf of Mexico (U.S. Environmental Protection Agency, 2000). Suspended sediment reduces clarity in streams and affects sight-feeding fish. Suspended sediment also interferes with water-treatment processes and recreational uses of streams. Excessive siltation can bury and suffocate fish eggs and bottom-dwelling organisms. In addition to in-stream effects, excessive sediment loading causes sedimentation problems in many downstream lakes and harbors and water-clarity problems in nearshore areas.

Many actions have been taken to reduce nutrient and suspended-sediment concentrations and the amount or load of nutrients and sediment transported in streams. In 1972, the Federal Water Pollution Control Act Amendments, commonly known as the Clean Water Act, were passed, and they established the basic structure for regulating discharges of pollutants into the waters of the United States (U.S. Environmental Protection Agency, 2006a). As result of the Clean Water Act, governmental efforts in the 1970s and 1980s primarily focused on regulating discharges from traditional "point source" facilities, such as municipal sewage plants and industrial facilities. In the 1980s and 1990s, the focus expanded to address nonpoint runoff, in other words, losses from agricultural areas, such as feedlots and fields, and losses from urban areas, such as construction sites and urban storm sewers. Under recommendations of the Clean Water Action Plan released in 1998, the U.S. Environmental Protection Agency (USEPA) developed a national strategy to develop waterbody-specific nutrient criteria for lakes and reservoirs, rivers and streams, wetlands, and estuaries (U.S. Environmental Protection Agency, 1998). The intent of this strategy is to require all States and tribes to establish nutrient standards that, if enforced, will continue to reduce nutrient concentrations and improve the beneficial ecological uses of surface waters. To determine if these actions have been successful, it is important to assess how nutrient and suspended-sediment concentrations and loads in streams have changed during recent years.

Changes in the concentrations of nutrients and suspended sediment in streams are the result of anthropogenic changes in the watershed, such as changes in the levels of sewage treatment or implementation of best management practices, and the result of changes in natural factors, such as streamflow or climatic change. To better detect changes as the result of anthropogenic factors, it is best to remove or factor out the variability associated with the natural factors. One of the most dominant natural factors affecting nutrient and suspended sediment in streams is streamflow. Concentrations of many water-quality constituents increase with increasing streamflow, especially those associated with particulates, whereas concentrations of others can decrease with increasing streamflow because of dilution. Therefore, when data are analyzed for trends, it is important to compensate for variability in streamflow.

Identification and analysis of trends in streamflow is of great interest to water-resource managers, scientists, and the public for a variety of important reasons. Long-term trends in streamflow potentially affect water levels in lakes and reservoirs; the availability of habitat for aquatic organisms; the availability of water for anthropogenic uses including recreation, irrigation, water supply, and waste disposal; aspects of bridge and dam construction; and flooding of low lying land. Trends in streamflow caused by climate may magnify the effects of land-use changes associated with anthropogenic activities, such as when increased precipitation causes flooding that is exacerbated by the increased amount of impervious areas associated with increased urbanization. Therefore, it is important to identify the trends in streamflow in addition to the trends in water quality.

Although many actions have been taken to reduce the concentrations and loads of nutrients and suspended sediments in streams across the country, most studies that have tried to evaluate whether or not these actions have been successful have examined the water quality of only a few streams from a specific area (such as Corsi and others, 2005) or within a specific State (such as Ruppel, 2006, for Wisconsin or Zipper and others, 1998, for Virginia). Only a few studies have examined trends over large geographical areas. For example, Stoddard and others (2003) examined water quality in streams from selected regions of the eastern and midwestern areas of the United States to assess changes in water quality as the result of recent reductions in nitrogen emissions.

To quantify how streamflow and nutrient and suspendedsediment concentrations and loads in streams across the country have changed as result of changes in land use and management practices, and the many actions taken to improve water quality, regional studies were initiated by the National WaterQuality Assessment (NAWQA) Program of the U.S. Geological Survey (USGS). The objectives of the regional studies are to describe changes or trends in streamflow and the associated trends in nutrient and suspended-sediment concentrations and loads that have occurred during a 1993-2004 base period and to try to understand what may have caused any of the substantial changes in water quality. Changes in total nitrogen, total phosphorus, and total suspended-material loads were examined from 1975 to 2003 at six sites to provide a longer term context for the data examined from 1993 to 2004.

The purpose of this report is to describe trends in streamflow and concentrations and loads of selected nutrients including total nitrogen, dissolved ammonia, dissolved nitrite plus nitrate, total organic plus ammonia nitrogen (Kjeldahl), total phosphorus, and dissolved phosphorus; total suspended materials; and total suspended sediment from 1993 to 2004 in streams at 49 selected sites within the north-central part of the 
United States. The report describes what may have caused the changes in water quality by examining changes in the major sources of nutrients in this area. Changes in concentrations and loads from 1975 to 2003 for six of these sites, which are distributed throughout the basins studied, are examined to place the trends observed for the 1993-2004 base period into a longer term context.

\section{Study Area and Environmental Setting}

The study area comprises four major river basins: the Upper Mississippi, Ohio, Red, and Great Lakes Basins (fig. 1). The Upper Mississippi River (UM) Basin is defined as the Mississippi River and its tributaries upstream from the confluence with the Ohio River, excluding the Missouri River. The Ohio River begins in eastern Pennsylvania at the confluence of the Allegheny and Monongahela Rivers and flows westward until it joins the Mississippi at Cairo, Ill. The Ohio River (OH) Basin includes the Ohio River and its tributaries, excluding the Tennessee River. The Red River (RR) Basin includes all rivers in the United States that drain northward to the southern basin of Lake Winnipeg, including the Red River of the North, the Souris River, and the Rainy River. The Great Lakes (GL) Basin includes all streams in the United States draining into the Great Lakes upstream from Montreal, Canada. Lake Michigan was joined with the Illinois River (UM Basin) through construction of the Chicago Sanitary and Ship Canal in 1900, a project engineered to reverse the flow of the Chicago River in order to divert Chicago wastewaters into the Upper Illinois River and away from the historic receiving water of Lake Michigan.

\section{Factors Affecting Nutrient and Suspended- Sediment Concentrations and Loads}

Various factors may cause changes in water-quality concentrations and yields such as climatic factors (precipitation and resulting runoff), land-use practices, and changes in the inputs of nutrients to the basin. To determine how these factors may have affected water quality, the distribution of each of these factors throughout the study area and how they have changed from 1993 to 2004 are described in the following sections.

\section{Precipitation and Runoff}

Precipitation and resulting runoff are the major factors that influence transport of nutrients from the land surface to streams. Precipitation ranges from about $38 \mathrm{~cm} / \mathrm{yr}$ in the western part of the study area to about $150 \mathrm{~cm} / \mathrm{yr}$ in the eastern part (fig. 2). The largest relative differences in precipitation are in the western part of the study area, and the smallest differences are in the eastern part. In the western part of the area, average precipitation ranges from about 38 to $80 \mathrm{~cm} / \mathrm{yr}$ over about $400 \mathrm{~km}$ (Winterstein and Lorenz, 2007). Evaporation ranges from about 97 to $102 \mathrm{~cm} / \mathrm{yr}$ in the southwestern part of the study area to about $71 \mathrm{~cm} / \mathrm{yr}$ in the north-central and southeastern parts of the study area (Farnsworth and others, 1982). These geographical differences in precipitation and evaporation result in a wide range in runoff from less than $2.5 \mathrm{~cm} / \mathrm{yr}$ in the northwest to about $75 \mathrm{~cm} / \mathrm{yr}$ in the southeastern part of the study area (fig. 3). This wide range in runoff results in a large variability in average streamflow volume and in loads of various water-quality constituents.

The regional precipitation map (fig. 2) can be used to divide the study area into three different geographic/climatic parts: the western, central, and eastern parts. The western part of the study area includes parts of North Dakota, South Dakota, and northwestern Minnesota. The climate is subhumid continental with warm summers and cold winters, and annual precipitation ranges from approximately 36 to $50 \mathrm{~cm}$. The central part of the study area includes most of the UM Basin in addition to areas draining to the Great Lakes, including parts of Minnesota, Wisconsin, Iowa, Illinois, and Indiana. The central part has a predominantly humid continental climate with annual rainfall ranging from approximately $50 \mathrm{~cm}$ in Minnesota to $115 \mathrm{~cm}$ in southern Indiana. The eastern part of the study area includes the Upper Ohio River Basin in addition to other drainages to the east and includes Ohio and parts of Pennsylvania and New York. This area also is humid continental and has annual precipitation ranging from approximately $85 \mathrm{~cm}$ in Ohio to $115 \mathrm{~cm}$ in Pennsylvania and New York. The northern regions of the central and eastern parts of the study area have warm summers and cold winters. The southern regions of the central and eastern parts of the study area have hot summers and cool winters.

Precipitation and associated streamflow generally has increased during the 20th century in the central part of the study area bordering the Great Lakes and UM Basin (Lins, 2005; Hodgkins and others, 2007). Many studies have predicted greater climatic variability in the future that could have far-reaching effects on hydrology, such as earlier and smaller annual snowmelt and increased evapotranspiration; on fish, aquatic vegetation, and agriculture; and, in the event of lower lake levels, disruptions of shipping and commerce (Sousounis and Bisanz, 2000).

Annual precipitation from 1975 to 2005 is shown for five sites in the study area (one site in the western part, two sites in the central part, and two sites in the eastern part) in figure 4, in which the period from 1993 to 2004 is identified. Precipitation in the western part increased during the period from 1993 to 2004 as shown by the data from Grand Forks, N. Dak. During 1993 to 2004, precipitation was variable in the central and eastern parts of the study area, except for a slight decrease in the precipitation at LaCrosse, Wis. The changes from 1993 to 2004 in the western part of the study area appear to be part of a long-term increase in precipitation; whereas, no consistent long-term change in precipitation is apparent in any other part of the study area. 


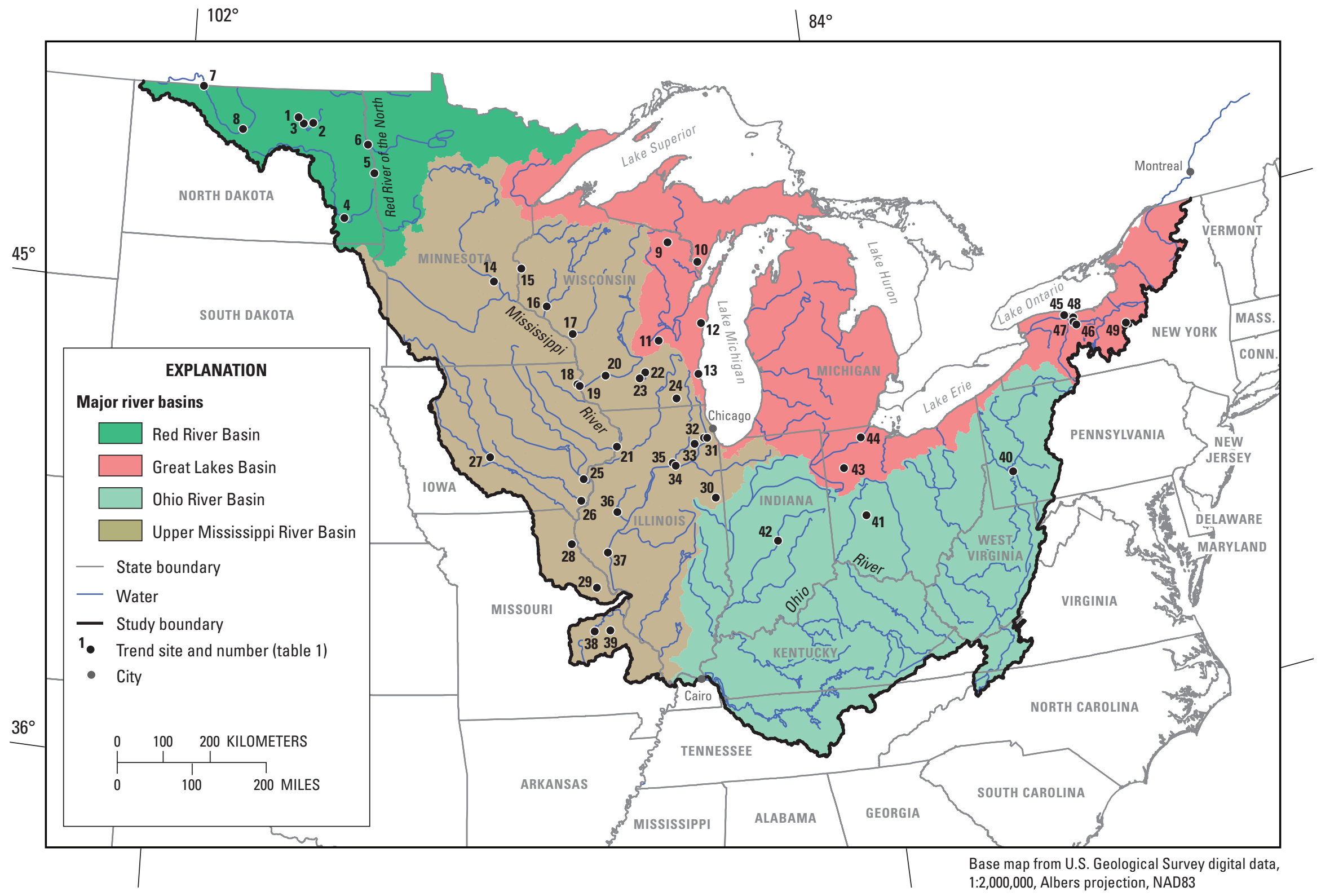

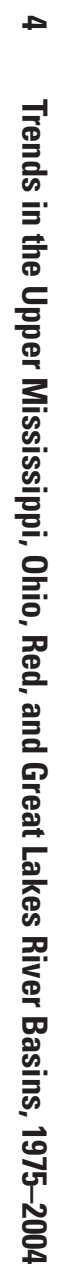

Figure 1. Study area, major river basins, and sites. Sites are described in detail in table 1. 


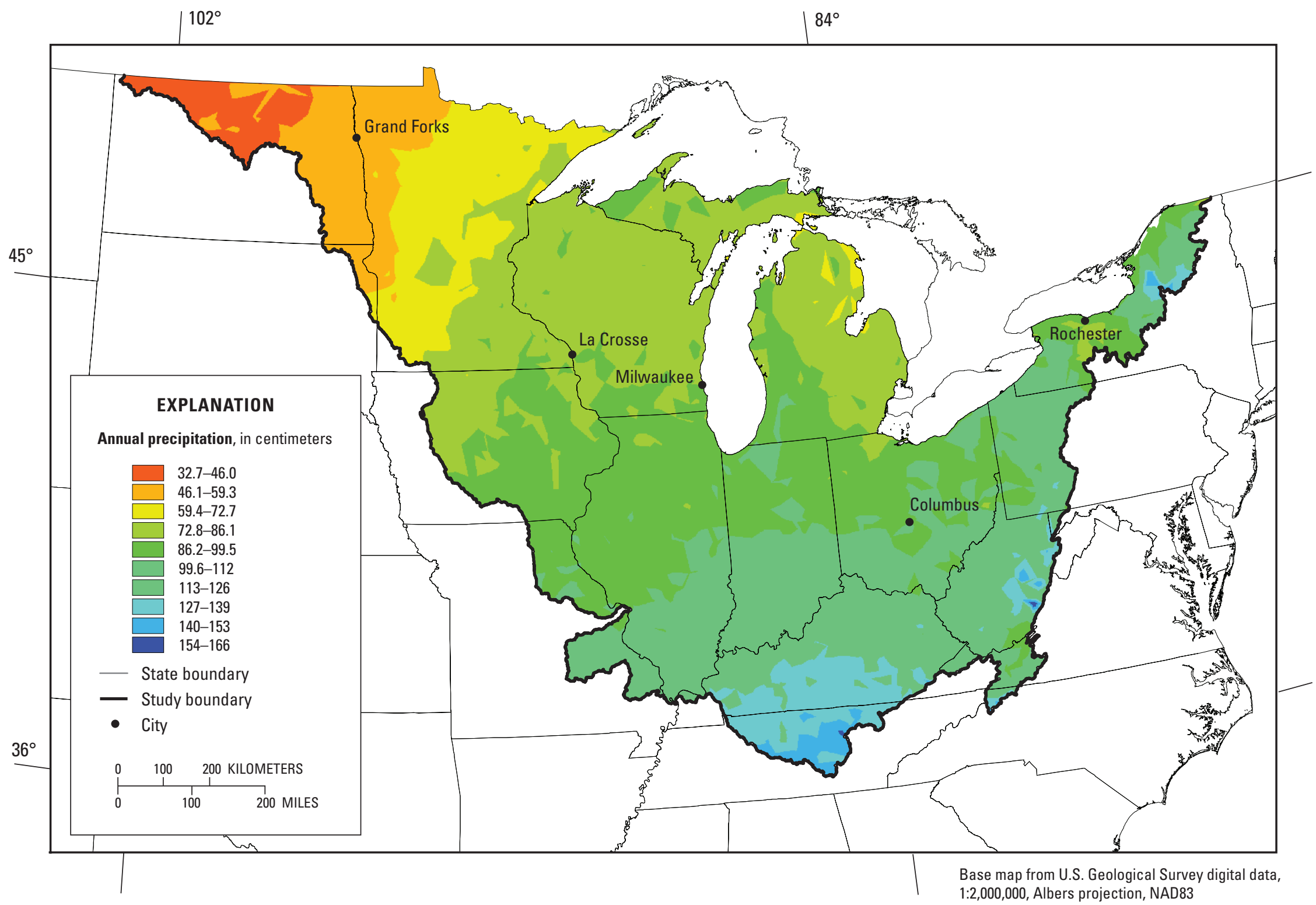

Figure 2. Average annual precipitation across the study area, 1971 to 2000 (National Climatic Data Center, 2002). 


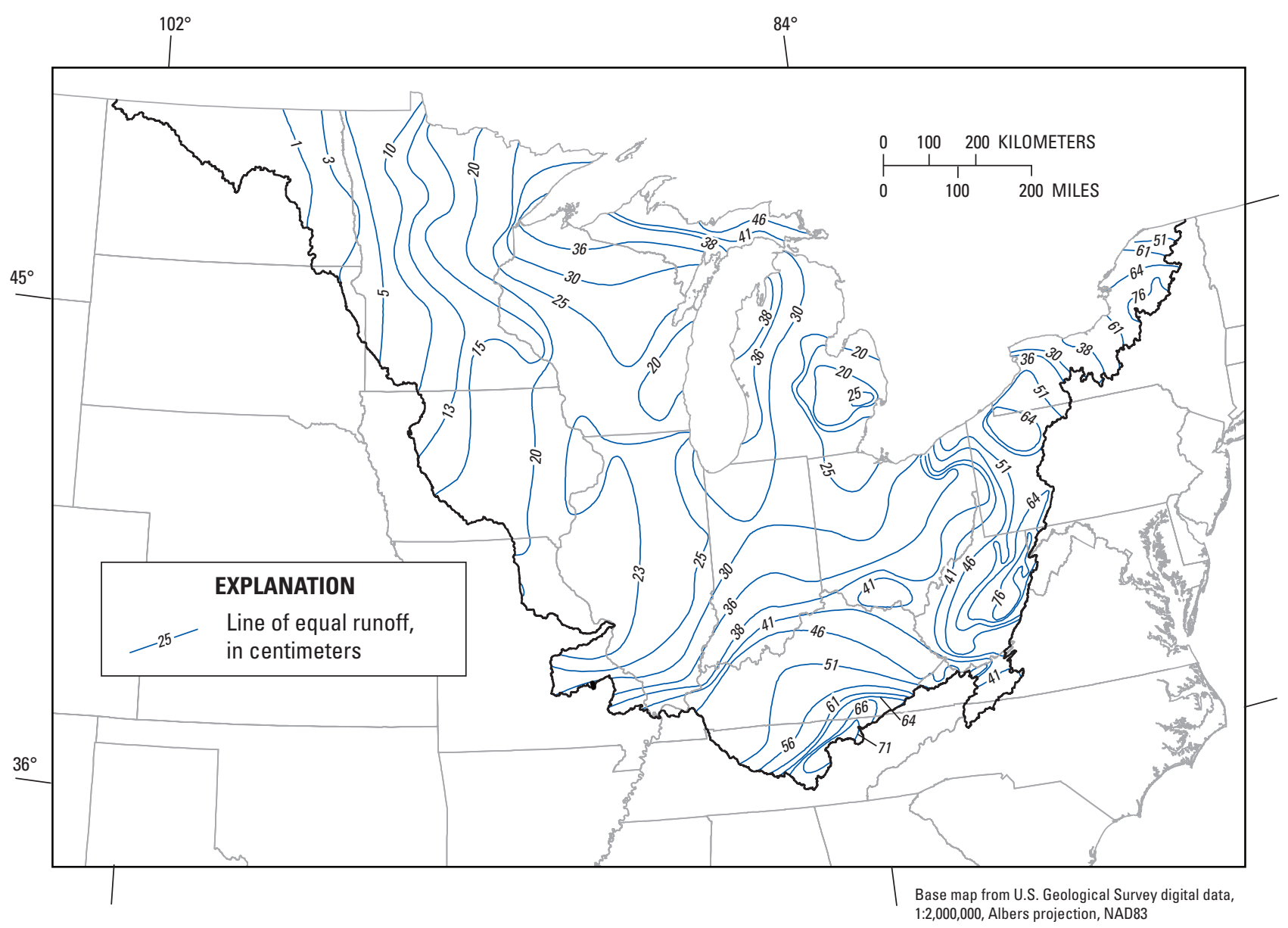

Figure 3. Average annual runoff across the study area, 1951 to 1980 (modified from Gebert and others, 1987).

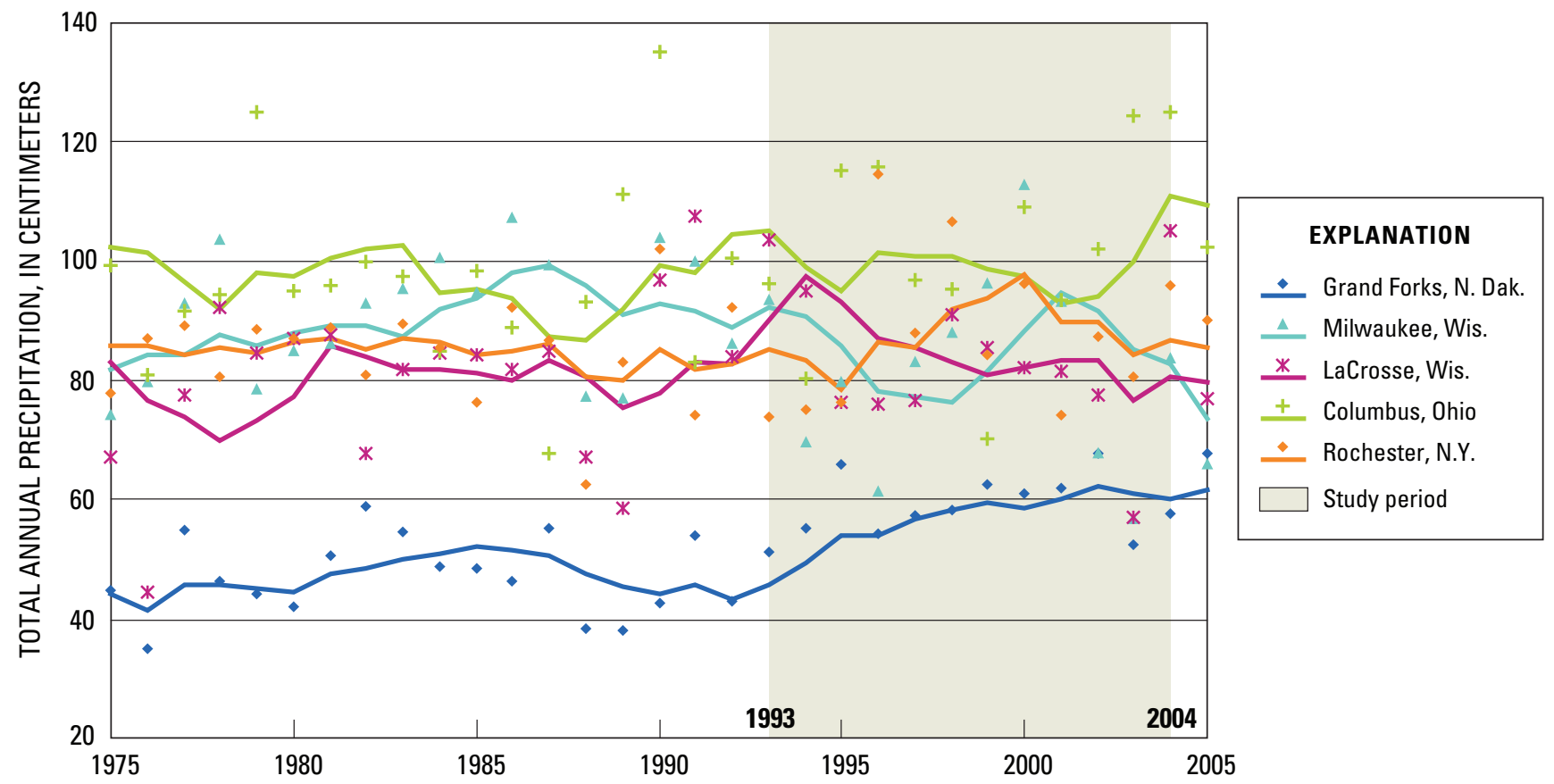

Figure 4. Annual precipitation from 1975 to 2005 at five sites in the study area. 


\section{Land Use}

Land use across the study area ranges from almost completely forested areas that are relatively unaffected by human activities in the north-central and southeastern parts, to extensively agricultural areas in the central part, to intensely urbanized areas around Chicago, Ill.; Milwaukee, Wis.; Minneapolis, Minn.; Detroit, Mich.; Cleveland, Columbus, and Cincinnati, Ohio; Pittsburgh, Penn.; Indianapolis, Ind.; and St. Louis, Mo. (fig. 5; U.S. Geological Survey, 2000). Population density by county is shown in fig. $6 \mathbf{A}$ (Geolytics, 2006). The extensive row-crop agricultural area (fig. 5) is known as the "corn belt," where the major crops are corn and soybeans. Small grains, primarily wheat and barley, are important crops in the western parts of the study area. These differences in land use result in differences in the amount of nutrients applied to the land surface and, potentially, the amount of nutrients that may reach and be transported down a stream and the amount of sediment eroded from the land.

The largest populations are found throughout the center of the study area, especially near the larger cities. Human population censuses, a surrogate for nutrients in wastewater effluent, were available for only 1990 and 2000. From 1990 to 2000 , the largest increases in population have occurred in the counties surrounding the largest cities in the central parts of Minnesota, Wisconsin, in the northern part of Lower Michigan, and the southeastern part of the study area, whereas populations have decreased in the far northwestern part of the study area (fig. 6 B). Changes in population may have caused changes in the magnitude of point-source discharges of nutrients from these areas; however, improvements in wastewater facilities may have offset some water-quality effects attributable to the increased population.

\section{Fertilizers and Manure}

Farmers apply fertilizers and manure to increase crop production. When those sources exceed crop needs or have not been incorporated into the soil before rain, nutrients can drain into streams (U.S. Environmental Protection Agency, 2005). Rates of total fertilizer nitrogen application are shown in fig. 7A by county for 1997, which was the middle of the study period (Ruddy and others, 2006). The distribution in nitrogen fertilizer use closely resembles the intensity of agriculture across the study area (fig. 5). The highest fertilizer application rates were in the central and western parts of the study area and encompass nearly all of Indiana, Illinois, and Iowa. The distribution of the rates of total fertilizer phosphorus application (not shown) closely resembles that for nitrogen. Changes in the annual fertilizer application were quite variable; therefore, the changes in fertilizer inputs were obtained by computing the change in the average inputs from 1993-95 to 2002-04. From about 1993 to 2004, rates of nitrogen fertilizer use generally have increased in northwestern North Dakota, and northeastern Minnesota, and most of Wisconsin, whereas rates of nitrogen use generally have decreased in the eastern part of the study area and in the eastern part of North Dakota (fig. 7B). From 1993 to 2004, rates of fertilizer phosphorus use generally have increased west of the Mississippi River, except in eastern part of North Dakota, and generally decreased east of the Mississippi River (fig. 7C).

The rates of total manure nitrogen application are shown for 1997 by county in figure 8 A (Ruddy and others, 2006). The highest application rates were in Iowa, southern Minnesota, southern Wisconsin and central Kentucky. The distribution of the rates of total manure phosphorus application closely resembles that for nitrogen (not shown). Manure data were available for only 1992, 1997, and 2002. From 1992 to 2002, the rates of manure nitrogen application have decreased by more than 15 percent throughout almost all of the study area except near the Iowa-Minnesota border, where the rates of application increased more than 25 percent (fig. 8 B). From 1992 to 2002, the rates of manure phosphorus application decreased by more than 15 percent throughout almost all of the study area except near the Iowa-Minnesota border, where the rates of application have increased more than 25 percent (fig. 8C).

\section{Atmospheric Deposition}

Atmospheric deposition can be an important source of nutrients to the land surface and to streams, especially in forested areas where there are few anthropogenic sources (U.S. Environmental Protection Agency, 2002). Atmospheric deposition of nitrogen can be elevated downwind of some types of agricultural animal production (Langland, 1992) and downwind of areas with fossil fuel combustion (Mason and others, 2002), such as cities. The annual rate of nitrogen input from atmospheric deposition in 1997 ranged from less than $350 \mathrm{~kg} / \mathrm{km}^{2}$ in the northwestern part of the study area to more than $600 \mathrm{~kg} / \mathrm{km}^{2}$ in southern Michigan, northwestern and southern Illinois, northern and southern Indiana, northern and southern Ohio, northeastern and western Kentucky, and the northeastern part of the study area (fig. 9A; Ruddy and others, 2006). Because the rates of atmospheric deposition are fairly consistent from year to year, the change from 1993 to 2004 is based on the values for those two years. From 1993 to 2004, the rates of deposition have decreased or changed very little throughout the southern two thirds of the study area and increased in the far northwestern part of the study area (fig. 9B). 


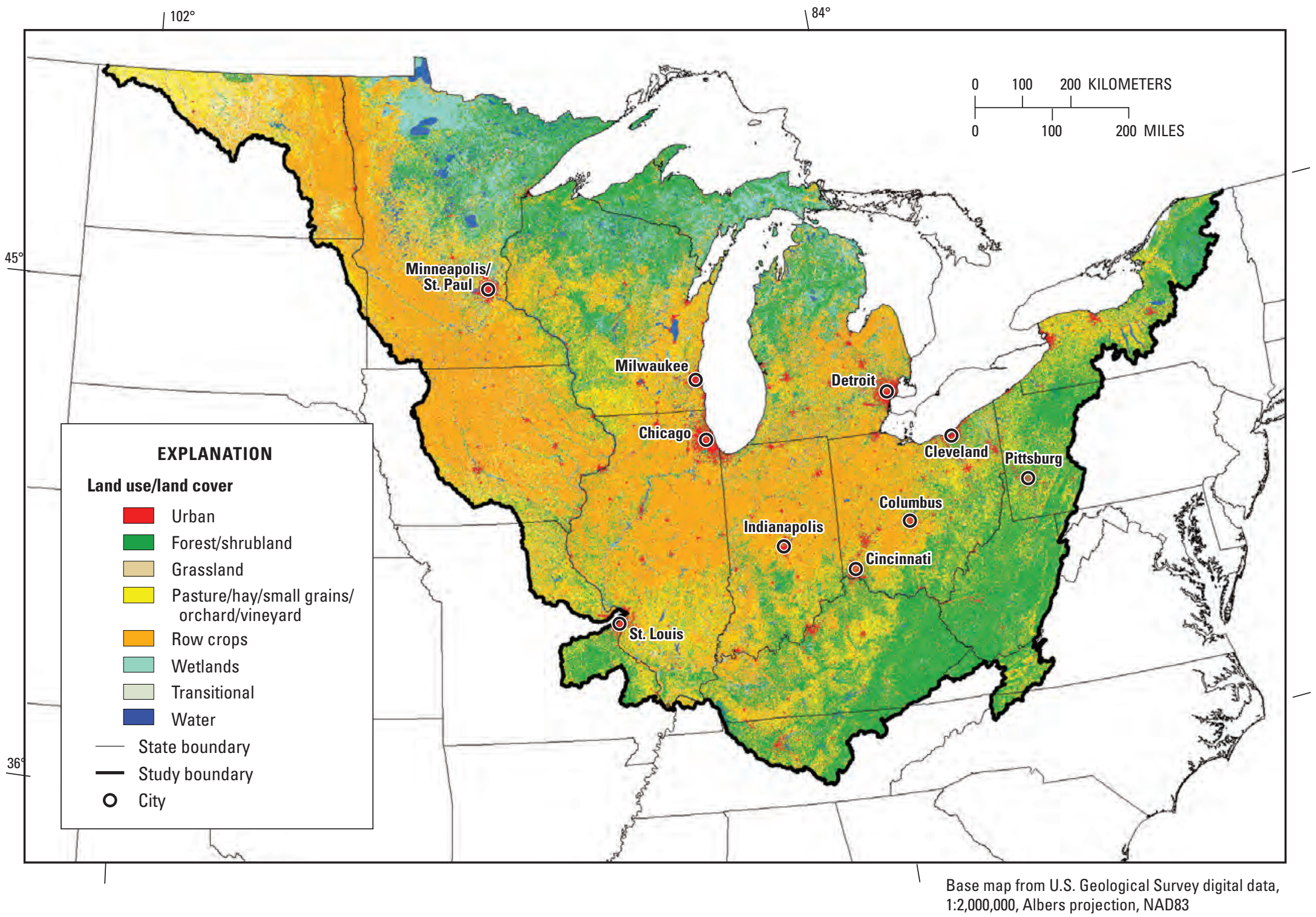

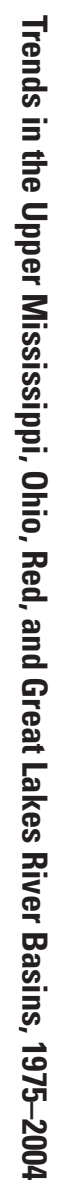

Figure 5. Land use and land cover across the study area (U.S. Geological Survey, 2000), with the 10 largest metropolitan areas identified. 


\section{A. Population, 2000}

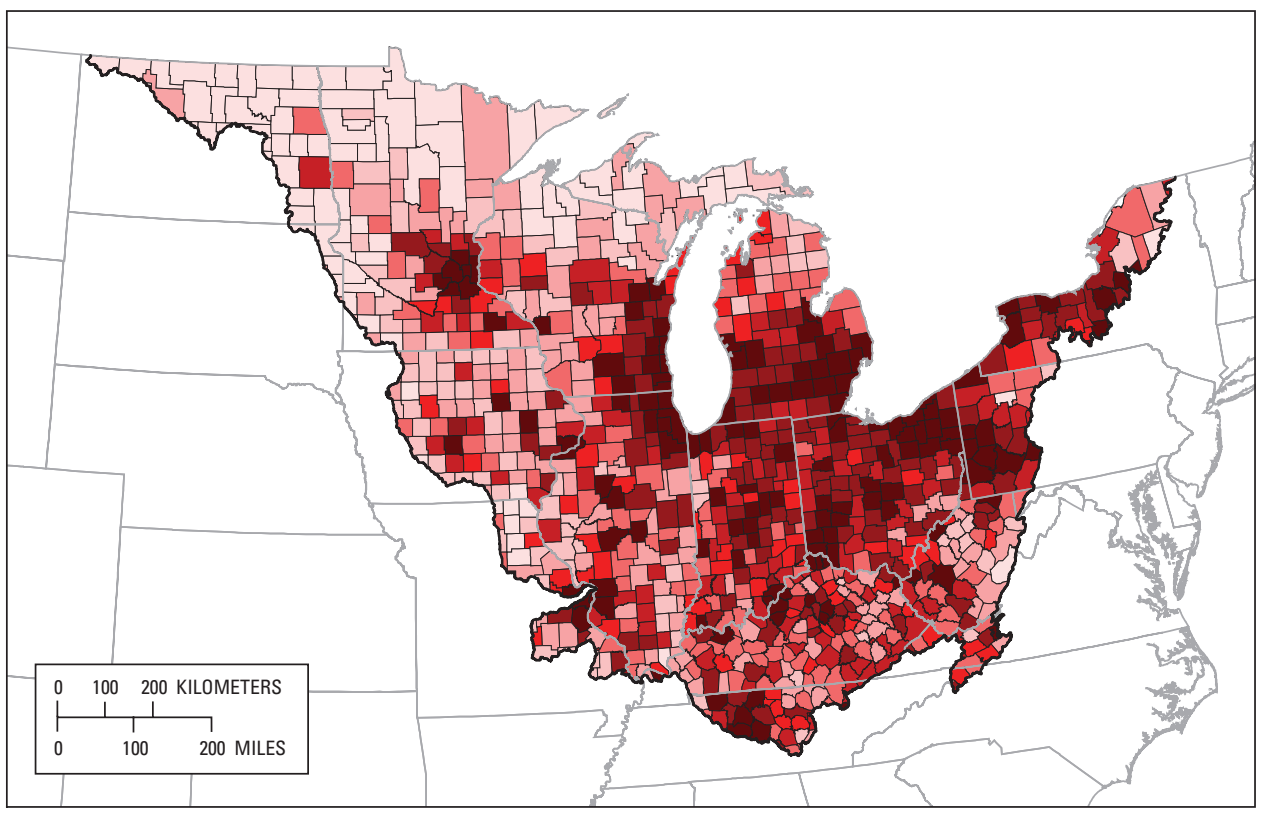

\section{B. Change in population, $1990-2000$}

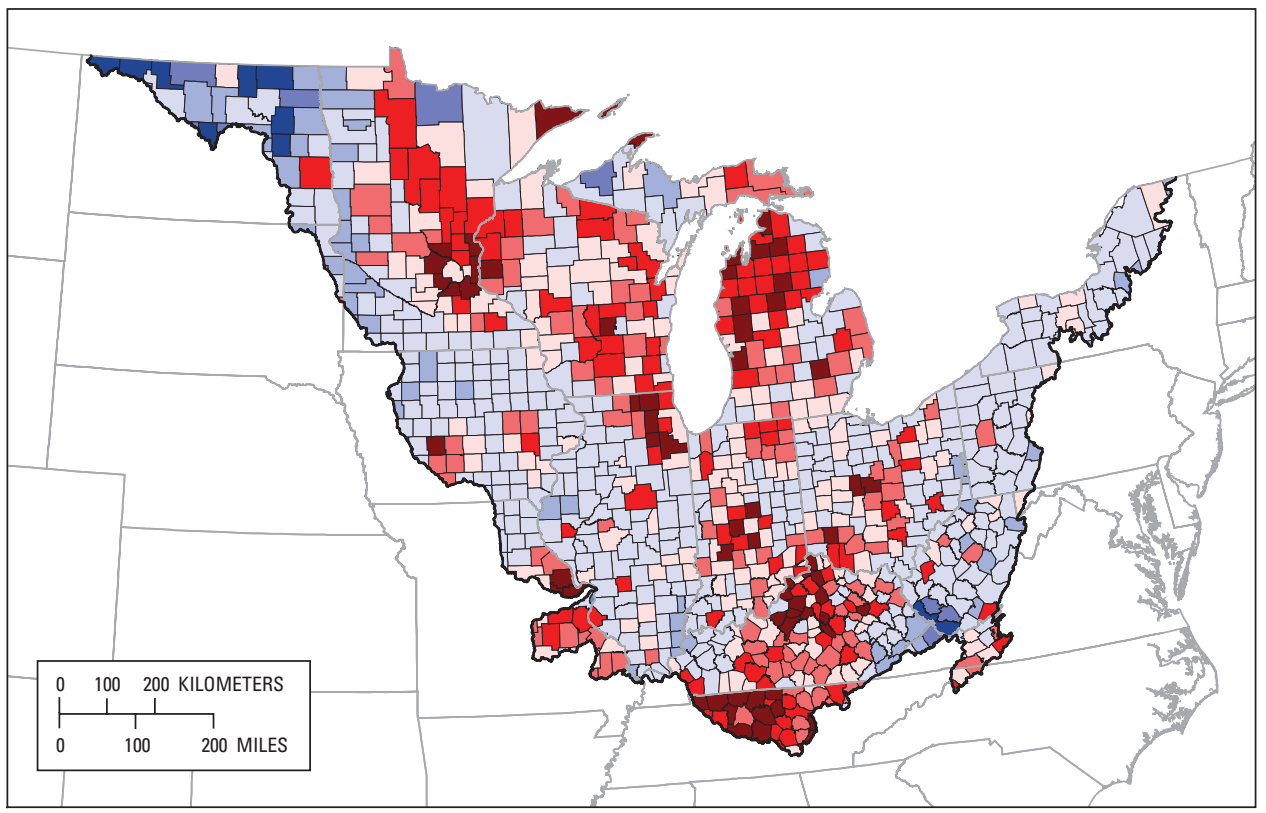

\section{EXPLANATION}

Population, in persons per square kilometer

$\square 0.66-6.15$
$\square .16-9.68$
$\square$
$9.69-14.3$
$14.4-20.3$
$20.4-25.6$
$25.7-34.9$
$35.0-71.9$
$72.0-2,170$

$-\quad$ Study area
- State boundary
- County boundary

\section{EXPLANATION}

Change in population, in percent

$\square<-15$

$-15--10$

$\square-10--5$

$\square-5-5$

$\square 5-10$

$\square 10-15$

$15-25$

$>25$

- Study area

- State boundary

- County boundary

Figure 6. Study area population by $\boldsymbol{A}$, county in 2000 and $\boldsymbol{B}$, county-level change from 1990 to 2000 (Geolytics, 2006). 
A. Fertilizer nitrogen application rate, 1997

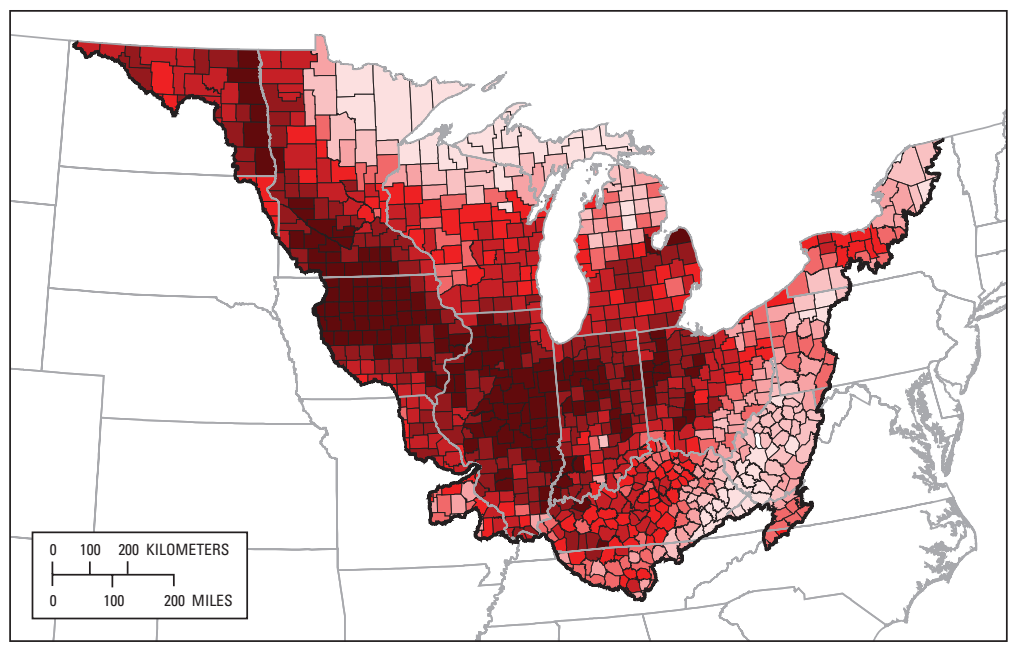

B. Change in fertilizer nitrogen application rate, 1993-1995 to 2002-2004

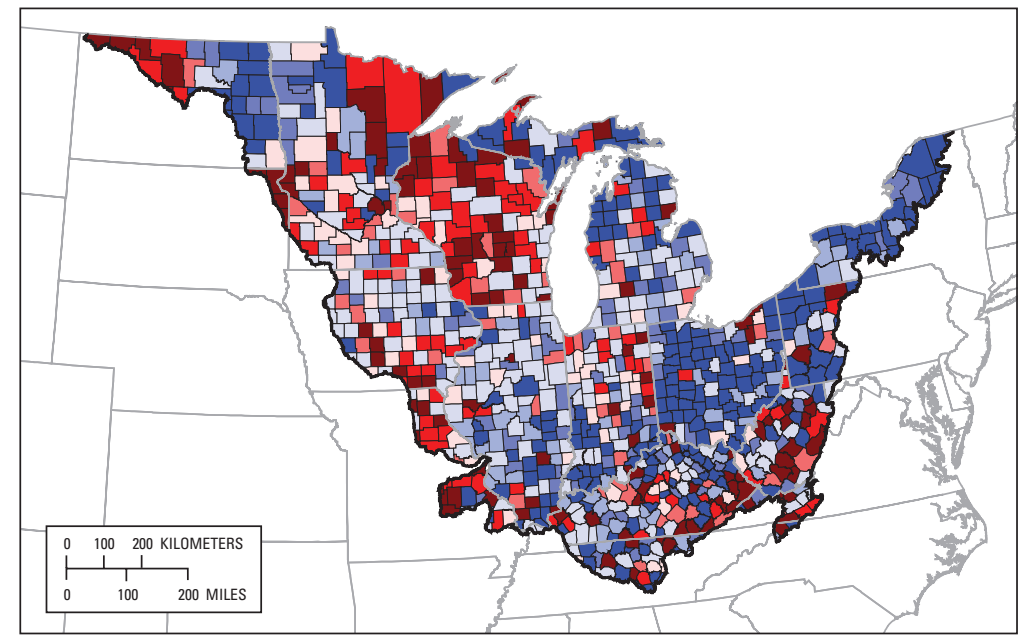

C. Change in fertilizer phosphorus application rate, 1993-1995 to 2002-2004

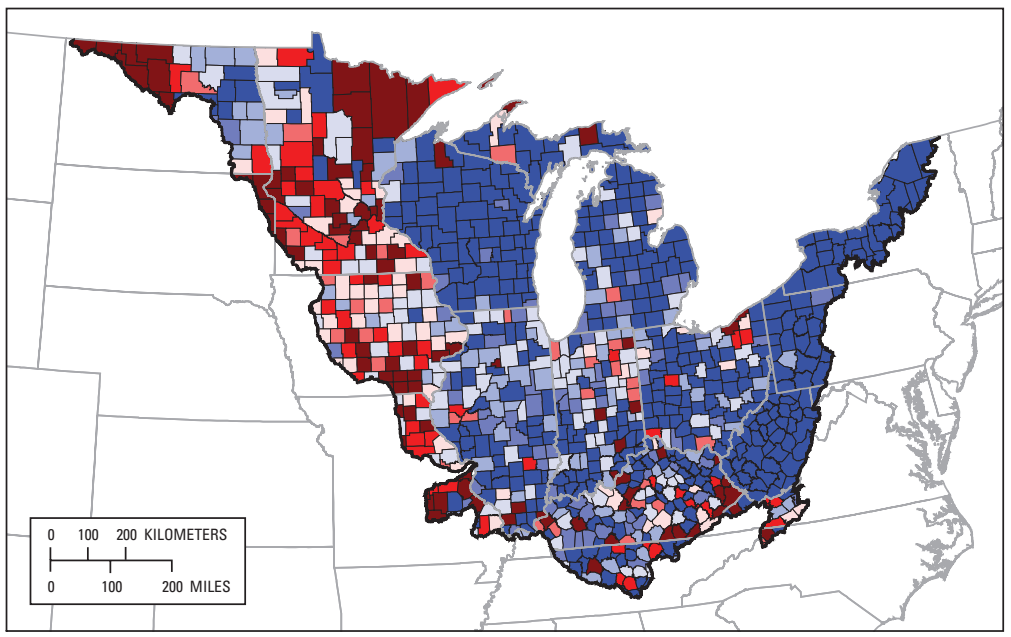

\section{EXPLANATION}

Application rate, in kilograms per square kilometer

$$
\begin{aligned}
& \square \text { 1-58 } \\
& \square \text { 59-224 } \\
& \square \\
& 225-597 \\
& 598-1,240 \\
& \square, 241-2,110 \\
& 2,111-3,840 \\
& 3,841-6,160 \\
& 6,161-9,300 \\
& -\quad \text { Study area } \\
& - \text { State boundary } \\
& - \text { County boundary }
\end{aligned}
$$

\section{EXPLANATION}

Change in application rate, in percent

$$
\begin{aligned}
& \square<-15 \\
& \square-15--10 \\
& \square-10--5 \\
& \square-5-5 \\
& \square-10 \\
& \square-10-15 \\
& \square-25 \\
& 15-25 \\
& >\text { Study area } \\
& - \text { State boundary } \\
& - \text { County boundary }
\end{aligned}
$$

\section{EXPLANATION}

Change in application rate, in percent

$$
\begin{aligned}
& \square<-15 \\
& \square-15--10 \\
& \square-10--5 \\
& \square-5-5 \\
& \square-10 \\
& 5-10 \\
& 15-25 \\
& 15-25 \\
& >25 \\
& - \text { Study area } \\
& - \text { State boundary } \\
& - \text { County boundary }
\end{aligned}
$$

Figure 7. Fertilizer nitrogen application by $\boldsymbol{A}$, county in 1997 and changes in application rates from 1993 to 2004 for $\boldsymbol{B}$, nitrogen and $\boldsymbol{C}$, phosphorus. (Data from Ruddy and others, 2006.) 
A. Manure nitrogen application rate, 1997

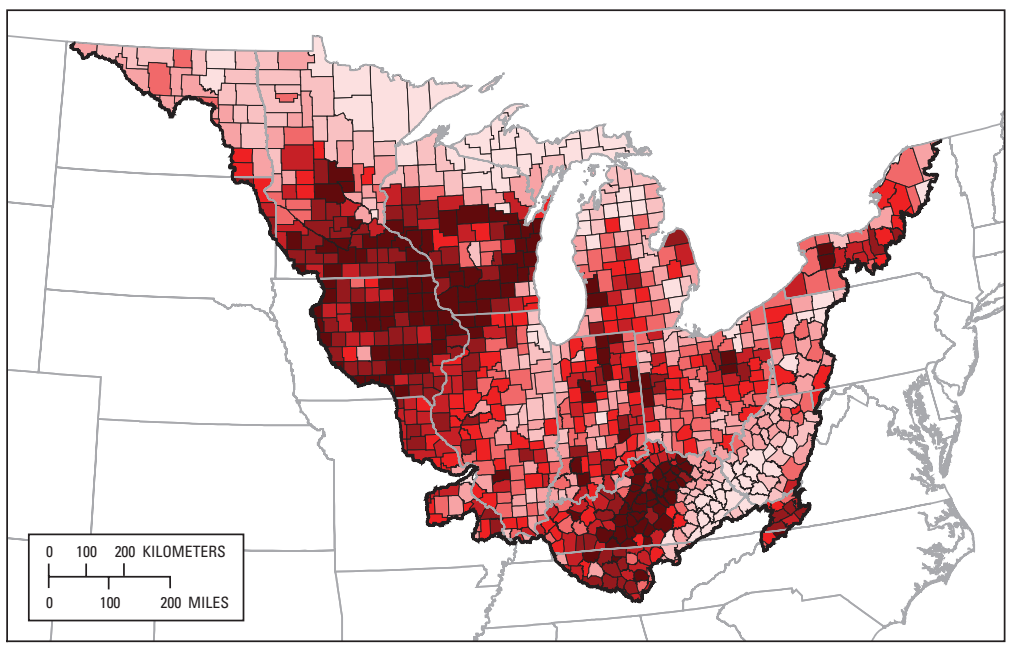

B. Change in manure nitrogen application rate, 1992-2002

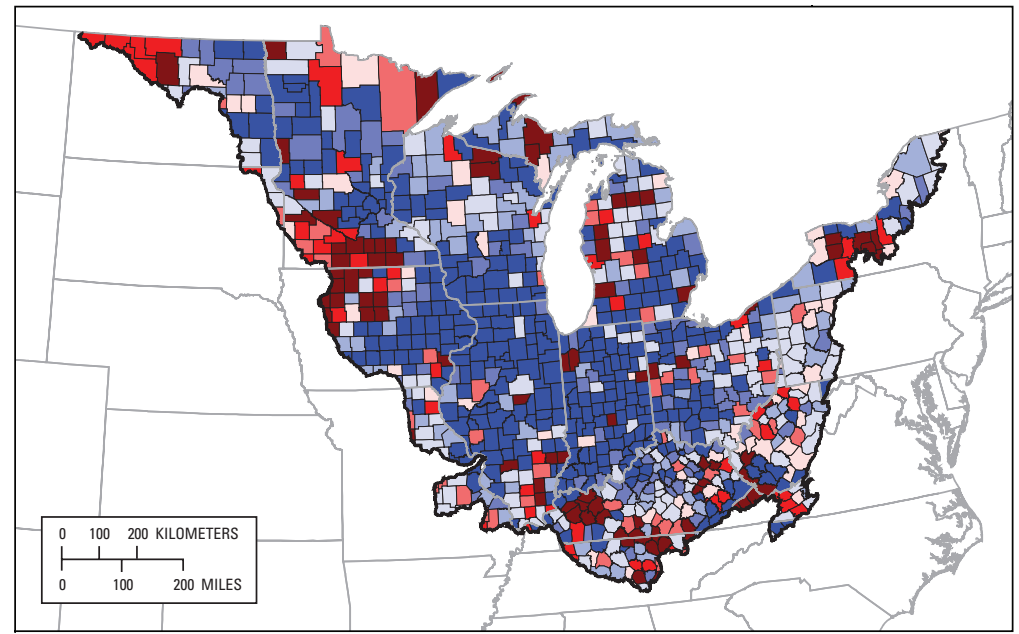

C. Change in manure phosphorus application rate, 1992-2002

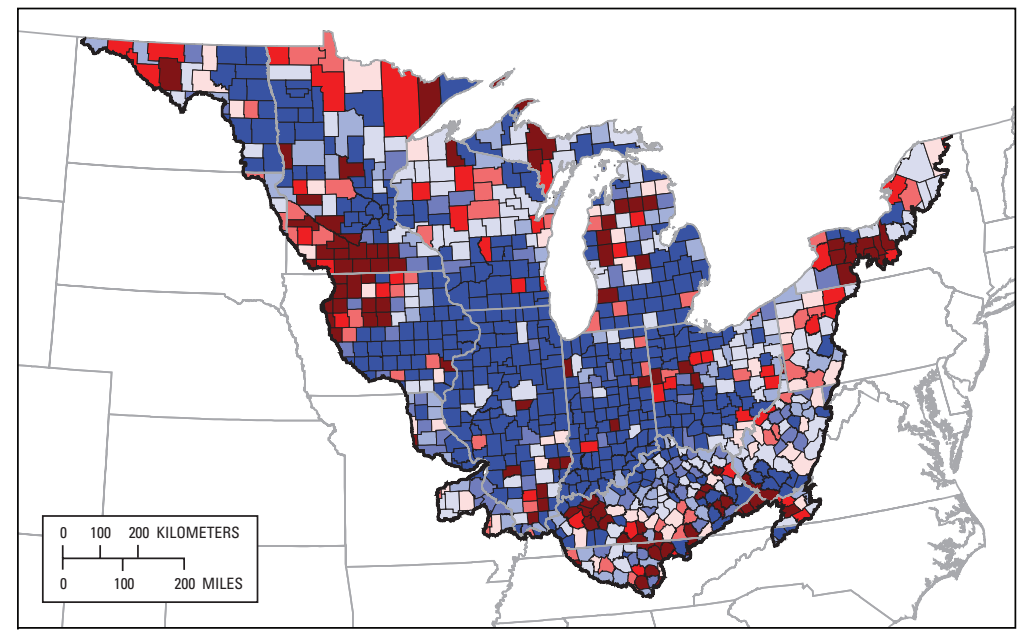

\section{EXPLANATION}

Application rate, in kilograms per square kilometer

$\square 0-111$
$\square \quad 112-295$
$\square$
$296-520$
$521-726$
$727-1,030$
$1031-1,360$
$1,361-1,810$
$1,811-7,090$
- Study area
- State boundary
- County boundary

\section{EXPLANATION}

Change in application rate, in percent

$$
\begin{aligned}
& \square<-15 \\
& \square-15--10 \\
& \square-10--5 \\
& \square-5-5 \\
& \square-10 \\
& 510-15 \\
& 15-25 \\
& >25 \\
& - \text { Study area } \\
& - \text { State boundary } \\
& - \text { County boundary }
\end{aligned}
$$

\section{EXPLANATION}

Change in application rate, in percent

$\square<-15$
$\square-15--10$
$\square-10--5$
$\square-5-5$
$\square-10$
$\square-10-15$
$15-25$
$>25$
- Study area
- State boundary
- County boundary

Figure 8. Manure nitrogen application rates by $\boldsymbol{A}$, county in 1997 and changes in application rates from 1992 to 2002 for $\boldsymbol{B}$, nitrogen and $\boldsymbol{C}$, phosphorus. (Data from Ruddy and others, 2006.) 


\section{A. Atmospheric nitrogen deposition rate, 1997}

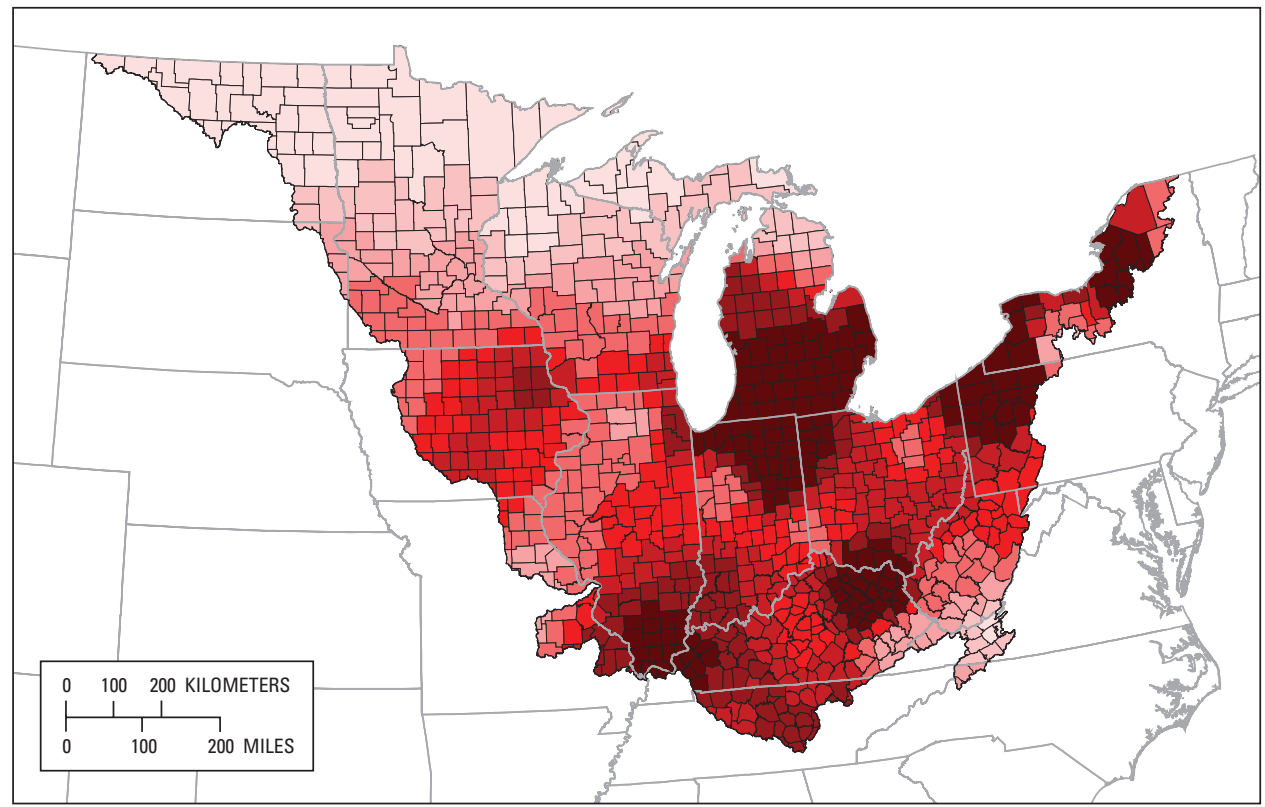

\section{EXPLANATION}

Deposition rate, in kilograms per square kilometer

$\square 74-348$
$\square \quad 349-419$
$\square$
$420-475$
$476-533$
$534-565$
$566-589$
$590-629$
$630-921$

$-\quad$ Study area
- State boundary
- County boundary

\section{B. Change in atmospheric deposition rate, 1993-2004}

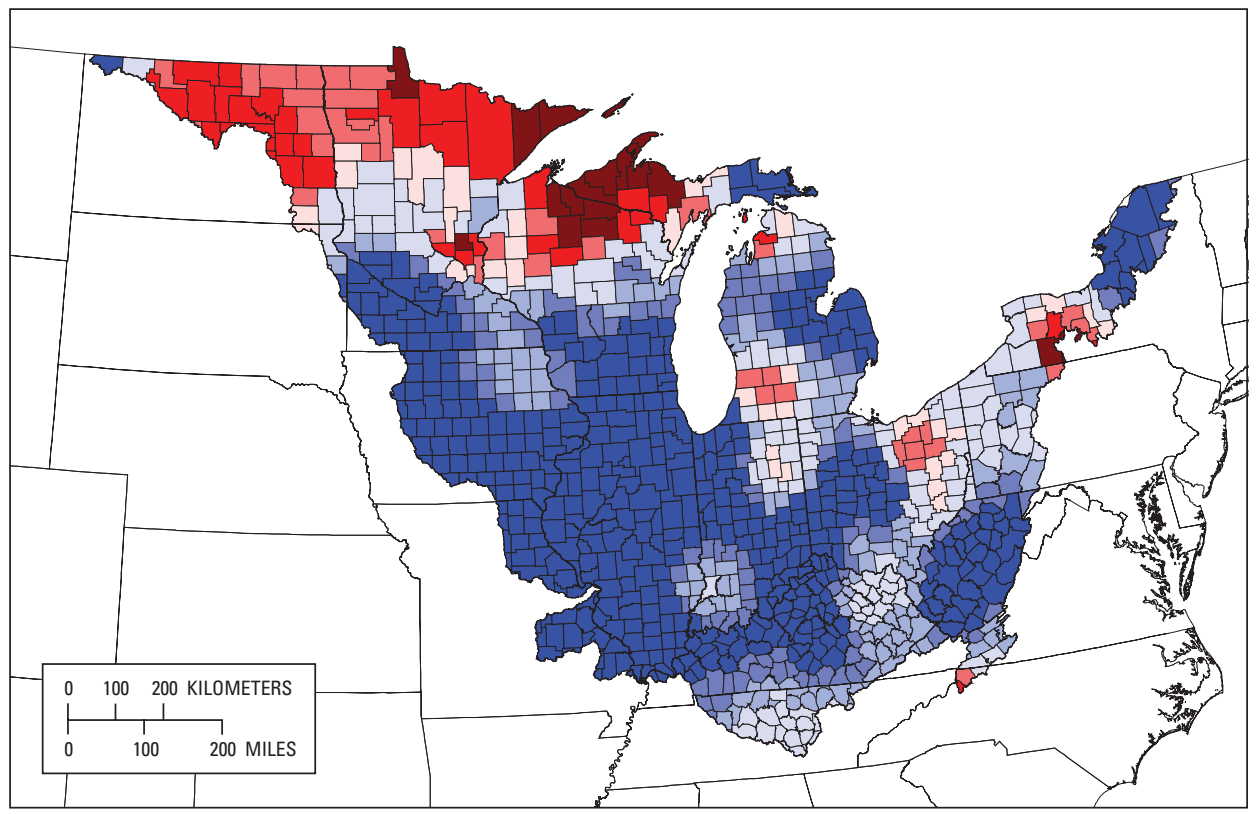

\section{EXPLANATION}

Change in deposition rate, in percent

$\square<-15$

$\square-15--10$

$\square-10--5$

$\square-5-5$

$\square 5-10$

$\square 10-15$

$\square 15-25$

$>25$

- Study area

- State boundary

- County boundary

Figure 9. Rates of atmospheric deposition of nitrogen by $\boldsymbol{A}$, county in 1997 and $\boldsymbol{B}$, changes in atmospheric deposition rates from 1993 to 2004. (Data from Ruddy and others, 2006.) 


\section{Total Nonpoint Sources of Nutrients}

The nonpoint sources of nitrogen to streams include fertilizers from agricultural, urban, and suburban areas; manure spread on cropland or from livestock pastures; and atmospheric deposition of nitrogen from fossil fuel combustion and other sources. The pattern of total nitrogen input from nonpoint sources by county for 1997 (fig. 10A) closely resembles the amount of row crop agriculture (fig. 5) in the area and application of fertilizer (fig. 7A) with highest inputs in the central and western parts of the study area. In general, the input from fertilizers is the dominant source of nitrogen, except in forested areas where the input from atmospheric deposition predominates. The change in the total nonpoint nitrogen input rate from 1993 to 2004 was computed by use of the 1992 and 2002 rates for manure, 3-year average rates around 1993 and 2004 for fertilizers, and rates for 1993 and 2004 for atmospheric deposition. From about 1993 to 2004, the total nonpoint input of nitrogen has increased in western Iowa, southern and northeastern Minnesota, northern Wisconsin, and the western one-half of the Upper Peninsula of Michigan, and decreased in the central and eastern parts of the study area (fig. 10B). The changes are not as consistent or widespread as the changes in the individual sources. Most of the total nonpoint-source changes were the result of the changes in fertilizer and manure inputs. In places where these changes were similar - such as increases in western North Dakota, eastern Minnesota, and northern Iowa, and decreases in Ohio - overall changes in nonpoint-source inputs were large. In places where the changes differed in sign, such as in Wisconsin and Illinois, overall changes in nonpoint-source inputs were small.

The distribution in the total input of phosphorus from fertilizers and manure closely resembles that for nitrogen; the input from atmospheric deposition has not been estimated, but is expected to be small compared to other sources of phosphorus. From 1993 to 2004, the total input rates of phosphorus decreased east of the Mississippi River, near the Mississippi River in Missouri and Iowa, and in eastern North Dakota, whereas the input rates increased throughout most of Minnesota, western North Dakota and Iowa, and in and near Tennessee (fig. 10C). In most places, the types of the changes in the phosphorus inputs were similar for fertilizers and manure.

The trends in the section "Trends in Nutrients and Suspended-Sediment Concentrations and Loads" are described with respect to patterns shown in figures 5-10 to determine if the changes in the input of nitrogen and phosphorus has affected the water quality, indicated by concentrations and loads, in the streams throughout the study area.

\section{Methods}

For this report, a trend is defined as a general change in concentrations or loads over time. Because of the complicating effects of natural and anthropogenic influences on water-quality conditions, it is important to consider three types of trends: (1) flow-adjusted trends in concentrations (FA trend)- - the trends in concentrations that would have occurred in the absence of natural variability in streamflow and seasonal effects; (2) total or overall trends in concentrations (OA trend) - the trends that represent changes in the overall effects on the stream ecosystem and include the effects of streamflow and seasonal variability and the effects of anthropogenic activities; and (3) trends in the load of a constituent- trends that directly include the changes in streamflow and the overall changes in concentrations. Changes in constituent loads are most important to downstream water bodies, such as the Gulf of Mexico or Lake Michigan. The following sections describe data, site selection, and trend and load computations.

\section{Water-Quality Data}

Water-quality data for trend analyses were limited to the nutrients total nitrogen, dissolved ammonia, total Kjeldahl nitrogen, dissolved nitrite plus nitrate, and total and dissolved phosphorus; and total suspended-material and suspendedsediment data measured in streams in the study area for which sufficient data were available between 1970 and 2004. For the purpose of analysis, suspended sediment was examined as suspended sediment (USGS parameter code 80154) alone and combined with total suspended solids (USGS parameter code 00530) into one constituent, total suspended material (SMAT). All data were compiled from data collected by the USGS and the major sampling agency(s) in each State. USGS data were retrieved from the National Water Information System (NWIS) and the NAWQA Program's Data Warehouse (http:// water.usgs.gov/nawqa/data). All of the State-agency data were obtained from USEPA legacy and modernized STOrage and RETrieval databases, known as STORET (http://www.epa.gov/ storet/), except for data from Illinois, which were collected by the Illinois Environmental Protection Agency and contained in NWIS; Indiana, which were collected by the Indiana Department of Environmental Management (C. Bell, Indiana Department of Environmental Management written commun., 2004) and Wisconsin, which was collected by the Wisconsin Department of Natural Resources (J. Ruppel, Wisconsin Department of Natural Resources written commun., 2004). 
A. Total nonpoint nitrogen input rate, 1997

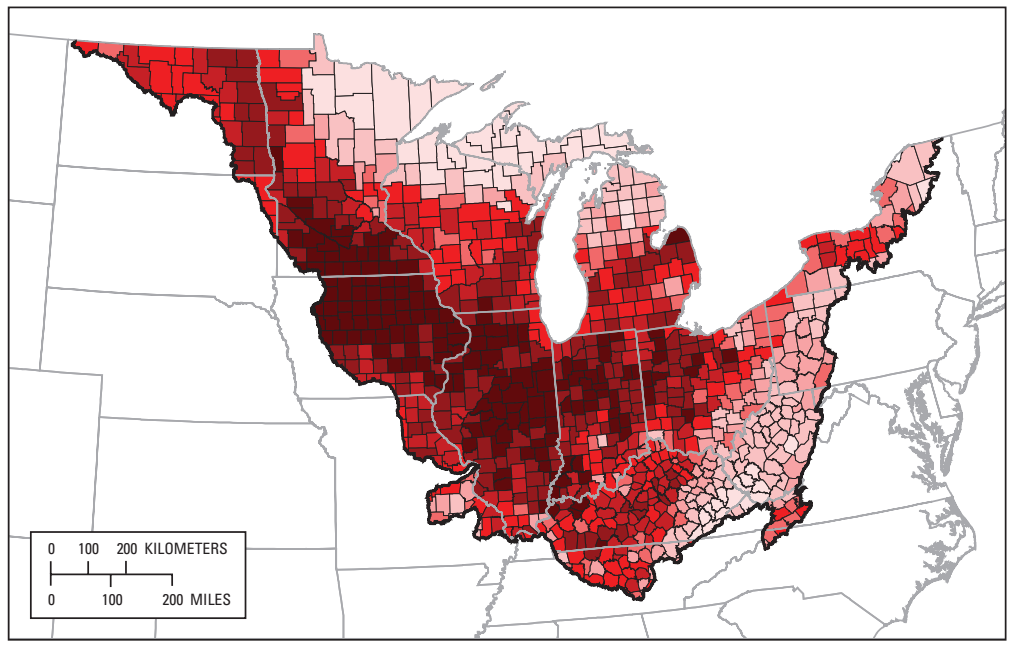

EXPLANATION

Input rate, in kilograms per square kilometer

$\begin{array}{ll}\square & 221-582 \\ \square & 583-1,430 \\ \square & 1,431-2,040 \\ \square & 2,041-2,730 \\ & 2,731-4,130 \\ & 4,131-5,640 \\ 5,641-7,860 \\ 7,861-14,700 \\ -\quad \text { Study area } \\ - \text { State boundary } \\ - \text { County boundary }\end{array}$

\section{B. Change in total nonpoint nitrogen input rate, 1993-2004}

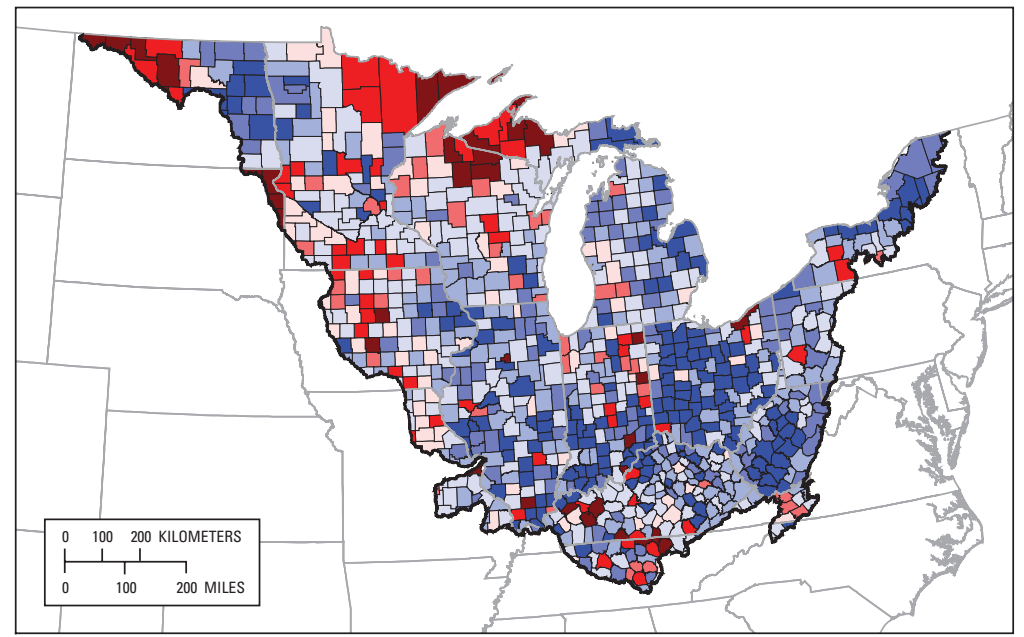

\section{EXPLANATION}

Change in input rate, in percent

$\square-15$
$\square-15--10$
$\square-10--5$
$\square-5-5$
$\square-10$
$50-15$
$15-25$
$>25$
- Study area
- State boundary
- County boundary

C. Change in total nonpoint phosphorus input rate, 1993-2004

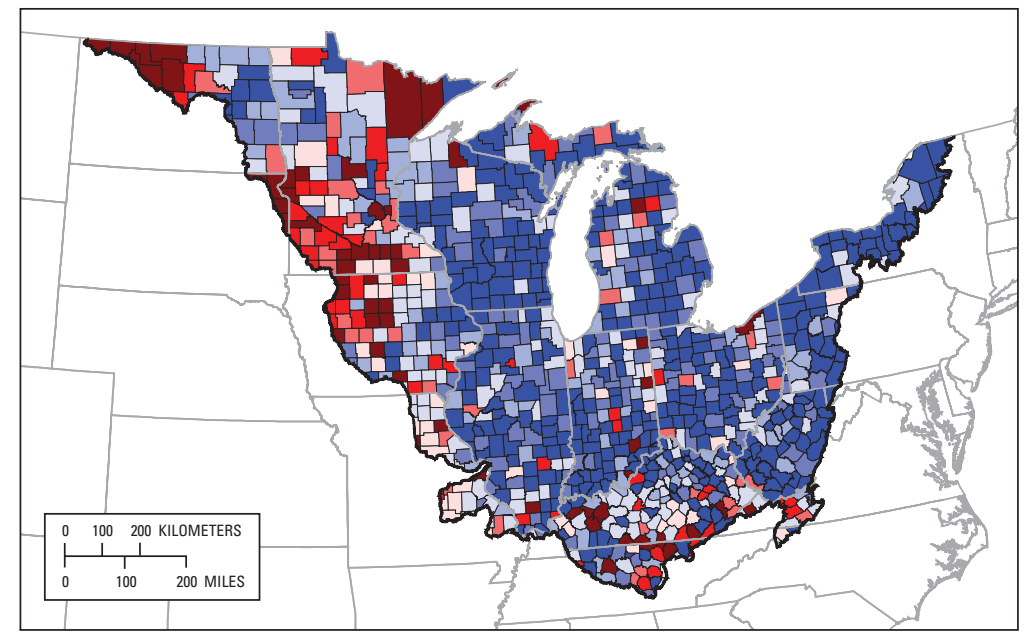

\section{EXPLANATION}

Change in input rate, in percent

$\square-15$
$\square-15--10$
$\square-10--5$
$\square-5-5$
$\square$
$5-10$
$10-15$
$15-25$
$>25$
$-\quad$ Study area
$\square$ State boundary
- County boundary

Figure 10. Total annual input rates of nitrogen from nonpoint sources (fertilizers, manure, and atmospheric deposition) by $\boldsymbol{A}$, county in 1997 and changes in the total input rates from 1993 to 2004 for $\boldsymbol{B}$, nitrogen and $\boldsymbol{C}$, phosphorus; atmospheric deposition of phosphorus was assumed to be negligible. 


\section{Streamflow Data}

For each water-quality site, a nearby streamflow gage was identified. A nearby gage was defined as a gage within the same stream system with a drainage-area ratio, which is the drainage area of the water-quality station divided by the drainage area of the streamflow gage, between about 0.3 and 2.0. A nearby gage with a long record was chosen over a nearby gage with a very short record. At each streamflow gage, all of the available daily streamflow data from 1970 to 2004 were obtained from USGS's Automated Data-Processing System (ADAPS) within NWIS (U.S. Geological Survey, 1998).

\section{Final Site and Sample Selection}

After the water-quality data were retrieved and matched to streamflow stations, the water-quality data were reviewed for completeness, quality-assurance samples were removed, and multiple daily samples were reduced to a single sample per day. For all of the multiple daily samples, the value of the constituent reported closest to noon was retained and all others deleted. Final site and sample selection involved three levels of screening. In the first level of screening, only sites with at least 15 samples for at least one constituent from a period of at least 2 years were retained, which resulted in approximately 1,700 sites. Data from the first level of screening were used to describe general patterns in median total nitrogen, total phosphorus, and suspended-material concentrations in streams throughout the entire study area.

A second level of screening was used to identify sites to describe general patterns in median annual yields or loads per unit area. Yields were computed to remove the effects caused by large differences in the size of the streams. Selection requirements for a site to be used to compute median annual yields were that it included at least 25 samples over a period of at least 2 years and at least 5 years of complete daily streamflow records; therefore, a site needed at least 5 years of complete estimated loads to compute a median annual yield. An annual yield was computed only if there were no missing daily flows for that year. The requirement of having 5 years of estimated load data to compute median values was used to reduce the potentially large effects of natural climatic variability. Approximately 700 sites were retained from the second level of screening. Data from the second level of screening were used to describe general patterns in median total nitrogen, total phosphorus, and suspended-material yields throughout the entire study area.

A third level of screening was used to select sites for the trend analyses. In this level, only sites that had at least 10 years of data for at least one constituent between 1993 and 2004, had at least 60 samples, and had a gage or a nearby gage with a drainage-area ratio ranging from 0.9 to 1.1 and streamflow record from 1993 to 2004 . A base period of 1993 to 2004 was selected because it is relevant to current conditions and represents the period since the beginning of the USGS NAWQA Program. For the final trend analyses in the base period, 49 sites met the criteria. The sites selected are listed in table 1 and shown on figure 1 . In table 1, the sites are divided among the western, central, and eastern parts of the study area. Eight of the sites were in the western part, 31 sites were in the central part, and 10 sites were in the eastern part of the study area.

A fourth level of screening was applied to each of the 49 selected sites for each constituent analyzed. At this level, 10 years of data and at least 60 samples were required for the constituent to be analyzed at the site. For total nitrogen, 24 sites were analyzed; for dissolved ammonia, 36 sites were analyzed; for total Kjeldahl nitrogen, 36 sites were analyzed; for dissolved nitrite plus nitrate, 29 sites were analyzed; for total phosphorus, 41 sites were analyzed; for dissolved phosphorus, 35 sites were analyzed; for SMAT, 42 sites were analyzed; and for total suspended sediment, 22 sites were analyzed.

To put the trends found for 1993 to 2004 into a longer term context, data from a subset of the final 49 sites were analyzed for long-term trends in flow-adjusted concentrations from 1975 to 2004. The trends in the flow-adjusted concentrations at six of these sites, which are distributed throughout the study area (table 1 and fig. 11), are shown graphically for each constituent. One site was in the western part, four sites were in the central part, and one site was in the eastern part of the study area. Of the four sites in the central part, three sites represented relatively small basins, and one site, Mississippi River at Clinton, Iowa, represented a large basin that integrates most of this area. Long-term trends in loads also were examined and shown graphically for these six sites. A description of the drainage basin for each of these six sites follows. Trends for the six long-term sites are presented, in order, on the basis of west to east.

The long-term western site drains the Souris River Basin, which occupies approximately $7,900 \mathrm{~km}^{2}$ in southeastern Saskatchewan and southwestern Manitoba in Canada and north-central North Dakota in the United States. The Souris River starts in southeastern Saskatchewan, enters the United States and flows southward before looping back into Canada. Most of the drainage basin of the Souris River near Sherwood, N. Dak., is in Canada and contains substantial forested, prairie, and agricultural (mostly grain crops) areas. Three large dams are upstream from the monitoring site: the Rafferty Alameda Dams, built in the 1990s and the Boundary Dam, built in 1957 (The Encyclopedia of Saskatchewan, 2008). The presence of these dams indicates that the flow at this site is intensively managed. A list of publications relating to water quality, land use, and basin characteristics in the Souris River Basin was assembled by the U.S. Geological Survey (2006b). 
Table 1. Description of sites used in trend analyses.

[USGS, U.S. Geological Survey; $\mathrm{km}^{2}$, square kilometer; agr, agriculture; for, forest; mix, mixed urban, agriculture, and forest; sites in bold indicate long-term evaluation sites]

\begin{tabular}{|c|c|c|c|c|c|c|c|c|c|}
\hline \multirow[b]{2}{*}{$\begin{array}{c}\text { USGS } \\
\text { site number }\end{array}$} & \multirow[b]{2}{*}{ Site name } & \multirow[b]{2}{*}{ State } & \multirow{2}{*}{$\begin{array}{c}\text { Map } \\
\text { number } \\
\text { (figure 1) }\end{array}$} & \multirow{2}{*}{$\begin{array}{c}\text { Drainage } \\
\text { area } \\
\left(\mathbf{k m}^{2}\right)\end{array}$} & \multirow[b]{2}{*}{ Major river basin } & \multicolumn{4}{|c|}{ Land use / land cover } \\
\hline & & & & & & $\begin{array}{c}\text { Percent } \\
\text { urban }\end{array}$ & $\begin{array}{c}\text { Percent } \\
\text { agriculture }\end{array}$ & $\begin{array}{c}\text { Percent } \\
\text { forest }\end{array}$ & $\begin{array}{c}\text { Dominant } \\
\text { type }\end{array}$ \\
\hline \multicolumn{10}{|c|}{ Western part } \\
\hline 05056100 & Mauvais near Cando & ND & 1 & 977 & Red River & 0.59 & 56.52 & 2.46 & Agr \\
\hline 05056200 & Edmore Coulee near Edmore & ND & 2 & 731 & Red River & .34 & 92.72 & 1.23 & Agr \\
\hline 05056239 & Starkweather Coulee near Webster & ND & 3 & 544 & Red River & .24 & 84.33 & .60 & Agr \\
\hline 05058700 & Sheyenne River at Lisbon & ND & 4 & 11,370 & Red River & .38 & 76.77 & 1.46 & Agr \\
\hline 05064500 & Red River of the North at Halstad & $\mathrm{MN}$ & 5 & 46,620 & Red River & .63 & 78.65 & 5.97 & Agr \\
\hline 05082500 & Red River of the North at Grand Forks & ND & 6 & 68,117 & Red River & .65 & 72.22 & 7.39 & Agr \\
\hline 05114000 & Souris River near Sherwood ${ }^{1}$ & ND & 7 & 7,876 & Red River & .02 & 7.45 & .00 & Agr \\
\hline 05120000 & Souris River near Verendrye ${ }^{1}$ & ND & 8 & 11,399 & Red River & .26 & 17.54 & .09 & Agr \\
\hline \multicolumn{10}{|c|}{ Central part } \\
\hline 04063700 & Popple River near Fence & WI & 9 & 360 & Great Lakes & 0.03 & 3.36 & 57.45 & For \\
\hline 04067500 & Menominee River near McAllister & WI & 10 & 10,181 & Great Lakes & .41 & 6.22 & 64.07 & For \\
\hline 04073468 & Green Lake Inlet near Green Lake & WI & 11 & 139 & Great Lakes & 3.88 & 78.96 & 6.54 & Agr \\
\hline 04085427 & Manitowoc River at Manitowoc & WI & 12 & 1,363 & Great Lakes & 1.41 & 78.53 & 9.16 & Agr \\
\hline 04087000 & Milwaukee River at Milwaukee & WI & 13 & 1,803 & Great Lakes & 8.30 & 65.11 & 16.45 & Agr \\
\hline 05287890 & Elm Creek near Champlin & $\mathrm{MN}$ & 14 & 223 & Upper Mississippi River & 8.13 & 55.32 & 11.79 & Agr \\
\hline 05340500 & St. Croix River at St. Croix Falls & WI & 15 & 16,166 & Upper Mississippi River & .57 & 23.25 & 52.13 & For \\
\hline 05369500 & Chippewa River at Durand & WI & 16 & 23,342 & Upper Mississippi River & .62 & 33.13 & 48.89 & For \\
\hline 05382000 & Black River near Galesville & WI & 17 & 5,389 & Upper Mississippi River & .61 & 39.95 & 52.60 & For \\
\hline 05389400 & Bloody Run Creek near Marquette & IA & 18 & 88 & Upper Mississippi River & 1.02 & 69.03 & 27.92 & Agr \\
\hline 05389500 & Mississippi River at McGregor & IA & 19 & 174,870 & Upper Mississippi River & 1.74 & 53.57 & 26.94 & Agr \\
\hline 05407000 & Wisconsin River at Muscoda & WI & 20 & 26,943 & Upper Mississippi River & 1.15 & 37.84 & 45.31 & For \\
\hline 05420500 & Mississippi River at Clinton & IA & 21 & 221,762 & Upper Mississippi River & 1.68 & 52.96 & 28.93 & Agr \\
\hline 05427718 & Yahara River at Windsor & WI & 22 & 191 & Upper Mississippi River & 2.37 & 91.71 & 3.63 & Agr \\
\hline 05427948 & Pheasant Branch at Middleton & WI & 23 & 44 & Upper Mississippi River & 6.10 & 85.81 & 4.30 & Agr \\
\hline 054310157 & Jackson Creek Tributary near Elkhorn & WI & 24 & 11 & Upper Mississippi River & 19.43 & 72.77 & 1.86 & Mix \\
\hline 05465500 & Iowa River at Wapello & IA & 25 & 32,383 & Upper Mississippi River & 3.12 & 83.63 & 4.80 & Agr \\
\hline 05474000 & Skunk River at Augusta & IA & 26 & 11,171 & Upper Mississippi River & 2.91 & 81.11 & 7.68 & Agr \\
\hline 05481650 & Des Moines River near Saylorville & IA & 27 & 15,132 & Upper Mississippi River & 2.15 & 88.93 & 2.96 & Agr \\
\hline 05500000 & South Fabius River near Taylor & MO & 28 & 1,606 & Upper Mississippi River & 1.45 & 67.92 & 19.96 & Agr \\
\hline 05514500 & Cuivre River near Troy & MO & 29 & 2,339 & Upper Mississippi River & .52 & 72.68 & 22.16 & Agr \\
\hline 05525500 & Sugar Creek at Milford & IL & 30 & 1,155 & Upper Mississippi River & .57 & 97.25 & .88 & Agr \\
\hline
\end{tabular}


Table 1. Description of sites used in the analyses. - Continued

[USGS, U.S. Geological Survey; $\mathrm{km}^{2}$, square kilometer; agr, agriculture; for, forest; mix, mixed urban, agriculture, and forest; sites in bold indicate long-term evaluation sites]

\begin{tabular}{|c|c|c|c|c|c|c|c|c|c|}
\hline \multirow{2}{*}{$\begin{array}{c}\text { USGS } \\
\text { site number }\end{array}$} & \multirow[b]{2}{*}{ Site name } & \multirow[b]{2}{*}{ State } & \multirow{2}{*}{$\begin{array}{c}\text { Map } \\
\text { number } \\
\text { (figure 1) }\end{array}$} & \multirow{2}{*}{$\begin{array}{c}\text { Drainage } \\
\text { area } \\
\left(\mathbf{k m}^{2}\right)\end{array}$} & \multirow[b]{2}{*}{ Major river basin } & \multicolumn{4}{|c|}{ Land use / land cover } \\
\hline & & & & & & $\begin{array}{c}\text { Percent } \\
\text { urban }\end{array}$ & $\begin{array}{c}\text { Percent } \\
\text { agriculture }\end{array}$ & $\begin{array}{c}\text { Percent } \\
\text { forest }\end{array}$ & $\begin{array}{c}\text { Dominant } \\
\text { type }\end{array}$ \\
\hline \multicolumn{10}{|c|}{ Central part-continued } \\
\hline 05531500 & Salt Creek at Western Springs & IL & 31 & 298 & Upper Mississippi River & 62.87 & 2.20 & 8.01 & Urb \\
\hline 05532500 & Des Plaines River at Riverside & IL & 32 & 1,632 & Upper Mississippi River & 38.85 & 31.98 & 10.72 & Urb \\
\hline 05540275 & Spring Brook at 87 th St. near Naperville & IL & 33 & 26 & Upper Mississippi River & 27.11 & 58.56 & 3.07 & Mix \\
\hline 05543500 & Illinois River at Marseilles & IL & 34 & 21,396 & Upper Mississippi River & 11.97 & 71.74 & 7.80 & Mix \\
\hline 05552500 & Fox River at Dayton & IL & 35 & 6,586 & Upper Mississippi River & 9.19 & 67.81 & 10.68 & Agr \\
\hline 05570000 & Spoon River at Seveille & IL & 36 & 4,238 & Upper Mississippi River & .82 & 84.50 & 11.77 & Agr \\
\hline 05586100 & Illinois River at Valley City & IL & 37 & 69,285 & Upper Mississippi River & 5.68 & 78.49 & 9.44 & Agr \\
\hline 07014500 & Meramec River near Sullivan & MO & 38 & 3,821 & Upper Mississippi River & .54 & 20.75 & 77.12 & For \\
\hline 07018100 & Big River near Richwoods & MO & 39 & 1,904 & Upper Mississippi River & 1.41 & 21.22 & 73.50 & For \\
\hline \multicolumn{10}{|c|}{ Eastern part } \\
\hline 03085000 & Monongahela River at Braddock & PA & 40 & 19,008 & Ohio River & 2.60 & 20.18 & 72.91 & For \\
\hline 03267900 & Mad River at St Paris Pike at Eagle City & $\mathrm{OH}$ & 41 & 803 & Ohio River & 2.40 & 80.20 & 14.50 & Agr \\
\hline 03353637 & Little Buck Creek near Indianapolis & IN & 42 & 44 & Ohio River & 44.72 & 41.69 & 2.99 & Urb \\
\hline 04186500 & Auglaize River near Fort Jennings & $\mathrm{OH}$ & 43 & 860 & Great Lakes & 2.05 & 88.53 & 7.98 & Agr \\
\hline 04193500 & Maumee River at Waterville & OH & 44 & 16,399 & Great Lakes & 2.61 & 87.09 & 7.36 & Agr \\
\hline 0422026250 & Northrup Creek at North Greece & NY & 45 & 26 & Great Lakes & 11.92 & 54.94 & 27.74 & Mix \\
\hline 04232034 & $\begin{array}{l}\text { Irondequoit Creek at Railroad Mills near } \\
\text { Fishers }\end{array}$ & NY & 46 & 102 & Great Lakes & 2.82 & 58.34 & 34.10 & Agr \\
\hline 0423204920 & East Branch Allen Creek at Pittsford & NY & 47 & 18 & Great Lakes & 18.58 & 53.32 & 17.52 & Mix \\
\hline 0423205025 & $\begin{array}{l}\text { Irondequoit Creek at Empire Boulevard in } \\
\text { Rochester }\end{array}$ & NY & 48 & 371 & Great Lakes & 22.62 & 41.35 & 23.75 & Mix \\
\hline 04237946 & $\begin{array}{l}\text { Onondaga Creek Tributary number } 6 \\
\text { downstream of mudboil area at Tully }\end{array}$ & NY & 49 & 1 & Great Lakes & .17 & 33.96 & 65.87 & For \\
\hline
\end{tabular}

${ }^{1}$ Statistics on land use/land cover represent U.S. portion only. 


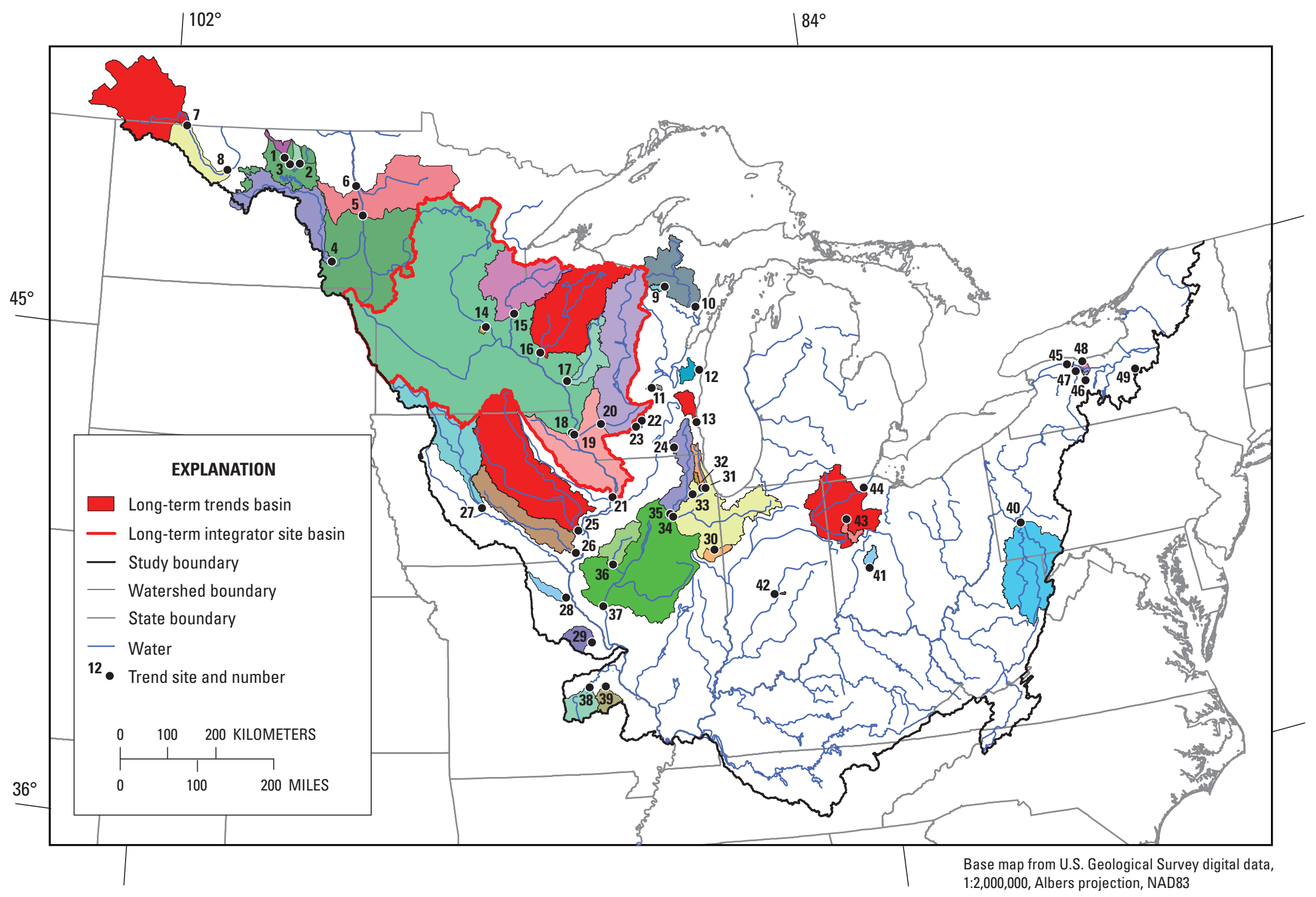

Figure 11. Sites used in the study. Drainage basins of the long-term trend sites are filled in red; the basin of the long-term integrator site on the Mississippi River is outlined in red. Sites are described in detail in table 1. 
The four long-term central sites are the Chippewa River at Durand, Wis., the Iowa River at Wapello, Iowa, the Milwaukee River at Milwaukee, Wis., and the Mississippi River at Clinton, Iowa. The Chippewa River Basin is in northwestern Wisconsin and has an area of about $23,300 \mathrm{~km}^{2}$. The upper part of this basin is largely undeveloped, contains several major parks and many State wildlife areas, and is one of the least-populated parts of the State. Major tributaries to the upper part of the Chippewa River include the Flambeau, Jump, Thornapple, Manitowish, Couderay, and Elk Rivers. The lower part of the basin has areas of agriculture and several moderate sized cities, such as Eau Claire. Major tributaries to the lower part of the Chippewa River include the Red Cedar and Eau Claire Rivers. The lower Chippewa River Basin contains many large areas of undeveloped native prairie and forest with numerous rare and endangered species of plants of animals (Wisconsin Department of Natural Resources, 2006). The site described in this report is located approximately $25 \mathrm{~km}$ upstream from the confluence of the Chippewa River and the Mississippi River. The characteristics of the downstream part of basin are described by Voss and Beaster (2001).

The Iowa River at Wapello, Iowa, is located near the confluence of the Iowa River and the Mississippi River. The drainage area at the monitoring site is approximately $32,400 \mathrm{~km}^{2}$ and extends from east-central Iowa to the Mississippi River. The Cedar River is a major tributary. The population of the basin was approximately 772,000 with 22 percent agricultural land use in 1960 and is expected to reach a population of nearly 2 million with only 4 percent agricultural land use by 2020 as farmland and forest lands are converted to urban, industrial, and residential uses (U.S. Army Corps of Engineers, 2004). Flow at this site is influenced by management of the Coralville Dam and reservoir, substantial irrigation demands, periodic flooding and flood plain management, and construction of agricultural levees. The basin has numerous waterquality problems including habitat degradation throughout the basin and severe problems with sedimentation in the lower parts of this basin (U.S. Army Corps of Engineers, 2004).

The Milwaukee River Basin comprises six basins that collectively cover approximately $1,800 \mathrm{~km}^{2}$. Grasslands, wetlands, forested lands, and agricultural land account for a large percentage of land in the upper Milwaukee River Basin; however, many of these areas are facing pressure from urban development as the greater Milwaukee metropolitan area continually expands to the northwest. The Milwaukee River and Estuary, downstream from the monitoring site, are listed by the USEPA as being an Area of Concern (U.S. Environmental Protection Agency, 2006b), where 11 water-quality impairments exist. Water-quality problems in the intensely urbanized lower Milwaukee River have caused beach closings, restrictions on fish consumption, restrictions on dredging activities, degradation of phytoplankton and zooplankton, restrictions on drinking-water supplies, extensive eutrophication, and disruption of animal reproductive cycles and health. Recently published reports documenting the water quality in the basin include Schneider and others (2004) and Hall (2006).
The Upper Mississippi River drains parts of Minnesota, Wisconsin, Iowa, and Illinois, and represents an integration of most of the central part of the study area. The Upper Mississippi River is one of the most regulated waterways in the world, with numerous dams, irrigation channels, locks, dredged waterways, and artificial channels. The site at Clinton, Iowa, has a drainage area of approximately $222,000 \mathrm{~km}^{2}$. The Upper Mississippi River Basin includes all types of land use, including a diverse array of habitats for birds, terrestrial animals, and aquatic species. A summary of water quality in the Upper Mississippi River was published by Sullivan and others (2002).

The long-term site in the eastern part of the study area is in the Maumee River Basin. The river flows through parts of Indiana, Ohio, and Michigan and has the largest drainage area of any Great Lakes river, with approximately $16,400 \mathrm{~km}^{2}$. Approximately 90 percent of the basin is agricultural, with the remaining area consisting of forest, urban, and industrial land use. The Maumee River Basin is the largest single source of sediment to Lake Erie and is one of the USEPA's "Areas of Concern" because of water-quality problems attributed to agricultural nonpoint-source pollution, contaminated industrial sites, combined sewer overflows, periodic dredging of the shipping channel sediments, and disposal of dredged materials (U.S. Environmental Protection Agency, 2006c).

\section{Data Manipulations}

Beginning in 1999, the USGS National Water Quality Laboratory (NWQL) began reporting the quantitation limit (QL) in addition to the method detection limit (MDL) for reporting censored data. The QL is larger than the MDL to reduce the chance of the actual concentration being greater than the MDL and reporting the data as censored at the MDL. Helsel (2005) reported biased results when using censored values at the QL instead of the MDL and offered three methods for modifying the data to avoid biased results. Method 1, which used the MDL instead of the QL, was used for all trend analyses. Table 2 summarizes the adjustments to censored data retrieved from the NWQL. All of the censored data used to describe the general spatial patterns in concentrations and yields were set to one-half of the detection limit.

Other adjustments to the reported concentrations also were made to data retrieved from the NWQL (David K. Mueller, U.S. Geological Survey, electronic commun., November 9, 2004). For dissolved ammonia, all concentrations reported with a value less than $0.02 \mathrm{mg} / \mathrm{L}$ prior to September 30, 1997, were set to less than $0.02 \mathrm{mg} / \mathrm{L}$. For total and dissolved phosphorus, all concentrations reported as a value less than $0.03 \mathrm{mg} / \mathrm{L}$ prior to September 30, 1998, were set to less than $0.05 \mathrm{mg} / \mathrm{L}$. Total nitrogen concentrations were not always reported in the databases, but individual nitrogen constituents were reported. Therefore, if dissolved nitrite plus nitrate and total Kjeldahl nitrogen concentrations were reported, total nitrogen concentrations were computed from the sum of these two constituents. 
Table 2. Adjustments applied to censored data values retrieved from the National Water Quality Laboratory.

[All values in milligrams per liter; $<$, less than]

\begin{tabular}{lll}
\hline \multicolumn{1}{c}{ Constituent } & \multicolumn{1}{c}{ Time frame } & \multicolumn{1}{c}{ Description of adjustment } \\
\hline Total nitrogen & No adjustments \\
\hline Dissolved ammonia & $\begin{array}{l}\text { Prior to Sept. 30, 1997 } \\
\text { After Sept. 31, 2000 }\end{array}$ & $\begin{array}{l}\text { Multiple censored values less than } 0.02 \text { were set to }<0.02 \\
\text { Censored values }(<0.041) \text { were set to }<0.021\end{array}$ \\
\hline Kjeldahl nitrogen & $\begin{array}{l}\text { Sept. 30, 1998, to Sept. 30, 2000, } \\
\text { and after Sept. 30, 2001 }\end{array}$ & Censored values $(<0.1)$ were set to $<0.05$ \\
& Sept. 31, 2000, to Sept. 30, 2001 & Censored values $(<0.05)$ were set to $<0.04$ \\
\hline Dissolved nitrite plus nitrate & Sept. 30, 2000, to Sept. 30, 2002 & Censored values $(<0.05)$ were set to $<0.023$ \\
& $\begin{array}{l}\text { After Sept. 31, 2002 } \\
\text { Total phosphorus }\end{array}$ & $\begin{array}{l}\text { Prior to Sept. 30, 1998 } \\
\text { Censored values }(<0.05 \text { and }<0.06) \text { were set to }<0.03\end{array}$ \\
& Sept. 30, 1999, to Sept. 30, 2000 & Values less than 0.03 were set to $<0.05$ \\
& After Sept. 30, 2000 & $\begin{array}{l}\text { Censored values }(<0.008) \text { set to }<0.004 \\
\text { Censored values }(<0.0037) \text { set to }<0.0019\end{array}$ \\
\hline Dissolved phosphorus & Prior to Sept. 30, 1998 & Values less than 0.03 were set to $<0.05$ \\
& Sept. 30, 1999, to Sept. 30, 2000 & Censored values $(<0.008)$ set to $<0.004$ \\
& After Sept. 30, 2000 & Censored values $(<0.0037)$ set to $<0.0019$ \\
\hline
\end{tabular}

\section{Basin Boundaries and Land-Use Classification}

Basin boundaries for all of the streams selected in the first level of screening to describe general spatial patterns were delineated and digitized from 1:24,000-scale USGS topographic quadrangle maps or 1:100,000-scale digital coverage of the USGS Hydrologic Unit maps (Seaber and others, 1984) refined with digital RF3 stream coverages (Clifford and others, 1993).

Each of the basins of the final 49 sites was classified into one of four land-use categories: urban, agriculture, forest, or mixed on the basis of the dominant land use from the NLCD land use and land cover data in figure 5 (table 1). If urban land use exceeded 10 percent of the basin, but was not the dominant land use, then the class "mixed" was used for that basin.

\section{Trend and Load Computations}

A generalized least-squares regression (GLS) method was used to model trends in streamflow. The model used all daily streamflow measurements available over the analysis period. It relates the log of daily streamflow to an intercept, a linear trend term that is measured by decimal time, and sine and cosine seasonal factors (also functions of decimal time). The GLS method accounts for long-term serial correlation of the streamflow data. The results are expressed as percent change per year, and the reference flow is the mean flow for the analysis period.

The regression method, which also is referred to as the rating-curve method, was used to quantify loads and evaluate trends in water quality. This method commonly is used for load estimation when infrequent water-quality data are available over long periods of time (Cohn, 2005). Daily loads $(L)$ were computed on the basis of relations between constituent load and two explanatory variables - streamflow and time. The regression models use the log-transform of load and streamflow to improve the linear relation and account for multiplicative errors. Nine different predefined regression models were used to estimate loads (table 3). Streamflow and time are transformed to produce variables that are statistically independent when squared terms are included, a process called centering. Because a log transformation was used in the models, computed daily loads were adjusted to account for a retransformation bias by use of the minimum variance unbiased estimate procedure (Cohn and others, 1989) or the adjusted maximum likelihood method (Cohn, 2005).

Table 3. Nine predefined regression models for estimating loads.

$\left[L\right.$, natural logarithm $(\log )$ of the estimated load; $Q^{*}$, centered log of streamflow; $T^{*}$, centered time (in decimal years); $T$, fraction of the year (expressed in decimal years); $\beta_{i}$, estimated coefficients]

\begin{tabular}{cl}
\hline $\begin{array}{c}\text { Model } \\
\text { number }\end{array}$ & \multicolumn{1}{c}{ Model description } \\
\hline 1 & $L=\beta_{0}+\beta_{1} Q^{*}$ \\
2 & $L=\beta_{0}+\beta_{1} Q^{*}+\beta_{2} Q^{* 2}$ \\
3 & $L=\beta_{0}+\beta_{1} Q^{*}+\beta_{2} T^{*}$ \\
4 & $L=\beta_{0}+\beta_{1} Q^{*}+\beta_{2} \sin (2 \pi T)+\beta_{3} \cos (2 T)$ \\
5 & $L=\beta_{0}+\beta_{1} Q^{*}+\beta_{2} Q^{* 2}+\beta_{3} T^{*}$ \\
6 & $L=\beta_{0}+\beta_{1} Q^{*}+\beta_{2} Q^{* 2}+\beta_{3} \sin (2 \pi T)+\beta_{4} \cos (2 \pi T)$ \\
7 & $L=\beta_{0}+\beta_{1} Q^{*}+\beta_{2} T^{*}+\beta_{3} \sin (2 \pi T)+\beta_{4} \cos (2 \pi T)$ \\
8 & $L=\beta_{0}+\beta_{1} Q^{*}+\beta_{2} Q^{* 2}+\beta_{3} T^{*}+\beta_{4} \sin (2 \pi T)+\beta_{5} \cos (2 \pi T)$ \\
9 & $L=\beta_{0}+\beta_{1} Q^{*}+\beta_{2} Q^{* 2}+\beta_{3} T^{*}+\beta_{4} T^{* 2}+\beta_{5} \sin (2 \pi T)$ \\
& $+\beta_{6} \cos (2 \pi T)$ \\
\hline
\end{tabular}




\section{Computation of Loads for General Spatial Patterns}

To describe the general patterns in yields or loads per unit area, annual loads, which are calculated by summing daily loads, were estimated by use of the Fluxmaster program (Schwarz and others, 2006). To simplify processing for this part of the analysis, model 7 (table 3 ) was used to compute loads for all constituents at all sites rather than calibrating a model for each basin. All of the water-quality data from 1970 to 2004 with available corresponding daily streamflow values were used in the analysis to estimate the regression coefficients. Daily loads were estimated for each site from 1970 to 2004. Total annual loads for general spatial patterns were computed for all water years, defined as the period from October 1 of the previous calendar year through September 30 of the current year, that had no missing daily streamflow values. Median annual loads were then computed for each site that had at least 5 years of data. Yields were then computed by dividing the median annual load by the drainage area of the basin.

The general spatial patterns of concentrations are expressed as median midmonthly concentrations, which are intended to reduce the variability of the random sampling of the constituent. The number of samples collected at each site was quite variable and ranged from quarterly to over a hundred in a year. Therefore, to obtain representative statistical summaries that were not biased by intensively sampled periods, the data were subsampled to monthly intervals. For each site, only one sample per constituent per month per year was used. The value included in the statistical summaries was the one collected closest to the middle of the month (midmonthly value). The midmonthly median is the median of all midmonthly values at a site.

\section{Computations of Trends and Detailed Loads for 1993 to 2004}

A version of LOADEST (Runkel and others, 2004) converted to run in S-PLUS (Insightful, 2005) was used to compute FA trends and loads. For each constituent at each site, the best model (table 3) identified by the Akaike information criterion (AIC) (Akaike, 1974) was selected and validated using all of the data from water year 1993 through water year 2004 (October 1, 1992, through September 30, 2004). The validation included checking the residuals for a linear fit, uniform scatter around the fit, normality of distribution, and linearity with all explanatory variables. If the model failed validation, then regression models were examined individually until a valid model was identified, or if no valid model was found, the analysis was dropped. For the analysis of trends, a time term was added to the model if it was not in the selected model.

The FA trend in concentrations at a site can be estimated from the coefficients in the equation chosen in the regression method. Consider the seven-parameter model shown by model 9 in table 3 . With adjustment to the estimated parameters, this could be a concentration model because
$L=C+Q+F$, where $C$ is the $\log$ concentration, $Q$ is the $\log$ streamflow, and $F$ is a units conversion factor. Only $\beta_{0}$ and $\beta_{1}$ need adjustment, as follows:

$$
\beta_{0}^{\prime}=\beta_{0}-F-Q^{a}
$$

and

$$
\beta_{1}^{\prime}=\beta_{1}-1
$$

where

$$
\begin{array}{cc}
Q^{a} & \text { is the center value for streamflow and } \\
\beta_{2} & \text { in model } 9 \text { is not changed because } Q \text { is } \\
\text { orthogonal (uncorrelated) to } Q^{* 2} .
\end{array}
$$

No other terms need adjustment because there is no streamflow component in them. The linear time terms $\left(\beta_{3}\right.$ and $\left.\beta_{4}\right)$ in model 9 describe the FA trend. This assumes that the "true" model for FA is quadratic in log streamflow and first order Fourier seasonal component.

The FA trend in concentrations expressed as an average percentage change per year is computed from the coefficients from the linear time terms, as follows:

$$
\% \triangle F A C / y r=100\left(e^{\left(2 \beta_{4}\left(T^{m}-T^{a}\right)+\beta_{3}\right)}-1\right),
$$

where

$\% \triangle F A C / y r \quad$ is the percent change in FA trend per year,

$e \quad$ is the base of the natural logarithms,

$\beta_{4}$ is the coefficient for the second-order linear time term in model 9 and zero otherwise,

$T^{m}$ is the midpoint of the period of record,

$T^{a}$ is the centering value of time, and

$\beta_{3}$ is the coefficient for linear time.

OA trends in concentrations and trends in loads are defined as the changes in model-estimated concentrations and loads over the period of the water-quality record, divided by the length of that record. The model-estimated concentrations and loads are determined by fitting separate trend models for streamflow and for the water-quality constituent. The streamflow model used the GLS method. The water-quality model, estimated from all water-quality measurements collected during the analysis period, is one of the models in table 3 that include a linear decimal time term; these model numbers are $3,5,7,8$, or 9 . The OA trend in the log of water-quality concentration is determined by streamflow and time trend components of the water-quality model, where the effect of the trend of streamflow is based on the coefficient for streamflow in the water-quality model. The OA trends in concentrations and loads are obtained by transforming the model-estimated, water-quality trend from log space to real space, computing the percentage of change corresponding to the first and last dates of the water-quality period of record, and normalizing by the length of this period. The significance of the trend was estimated by the $\mathrm{p}$-value of a t-test using standard errors of estimated typical values. A more complete description of the methods used to compute trends is given in Sprague and others (2006), where the OA trend is referred to as nonflow-adjusted trend. 
The results for nutrients and suspended materials are reported in estimates of unit trends - trends expressed in the units of concentration or load; for example, milligrams per liter per year $(\mathrm{mg} / \mathrm{L} / \mathrm{yr})$ or kilograms per year $(\mathrm{kg} / \mathrm{yr})$. The unit trends in concentrations and loads are determined by multiplying the estimated trends in concentrations and loads by the appropriate reference value for concentration or load. For example, if the estimated trend was 10 percent per year and the reference concentration was $3 \mathrm{mg} / \mathrm{L}$, then the unit trend would be $0.10 / \mathrm{yr} * 3 \mathrm{mg} / \mathrm{L}=0.3 \mathrm{mg} / \mathrm{L} / \mathrm{yr}$. The reference concentration is obtained by evaluating the water-quality model at reference conditions consistent with the trend in water quality at the beginning of the water-quality period of record. These conditions include setting the log of streamflow to its smoothed trend value corresponding to the first day of the water-quality period, setting the trend term to the decimal equivalent of the first day of the water-quality period, and setting the sine and cosine seasonal factors to their average values over the full water-quality period. The log value of the reference concentration is transformed to real space and a multiplicative retransformation factor is applied to correct for statistical bias arising from sample error in the water-quality model coefficients. The reference load is computed similarly, except the logarithm of streamflow trend, as determined by the linear streamflow equation evaluated at the starting date of the water-quality period, is added to the log value of the reference concentration prior to transformation to real space; in addition, a multiplicative constant is applied to convert the result to appropriate load units. The same reference concentration is used to derive the FA and OA trends in concentrations; the same reference load is used in the evaluation of trends in loads.

The FA trends in concentrations, being independent of streamflow conditions, are best used to evaluate changes in water quality arising from changes in pollution sources or management activities within a basin. Conversely, the OA trend is indicative of the water-quality changes that riverine habitats have actually experienced. If there is no trend in streamflow over time, then the two estimates of trend are equivalent. Because the water-quality model used to derive these trends includes streamflow as a predictor, the estimates of trend are immune to potential biases arising from preferential water-quality sampling during high-streamflow events. Care should be taken, however, in interpolating or extrapolating these trend estimates within or beyond a site's period of record or in making comparisons of trend across sites that have different periods of record. Due to the possible nonlinearity of trends, such as arising from nonlinear specifications of the water-quality model's streamflow or trend components, trends within the water-quality period, or trends experienced outside this period, could be quite different from the trends reported for this study.

The attained p-values, the probability of obtaining a statistic as likely as the computed statistic when the null hypothesis is true, associated with each observation are based on a two-sided test, which means that either an upward or a downward trend could be identified (Helsel and Hirsch, 2002). The null hypothesis for a two-tailed trend test is that the trend is zero. The alternative hypothesis is that the trend is not zero. For a particular criterion for rejecting the null hypothesis, the critical region of the test statistic is in the tails of the distribution. For example, if the criterion is set to 0.05 , a value in the inner 95 percent of the test statistic would not result in rejecting the null hypothesis, but a value in either the upper or lower 2.5 percent would result in rejecting the null hypothesis and accepting the alternative hypothesis that there is a trend in the data. To characterize regional patterns in trends, a 0.1 criterion was used to reject the null hypothesis.

When making multiple tests of trends, the effects of those multiple tests on accepting or rejecting the null hypothesis must be considered. For example, use of a criterion of 0.05 for rejecting the null hypothesis would result in an incorrect conclusion in 5 percent of the tests. For a single test, that could be an acceptable risk. For the 49 sites that were analyzed in this study, it could be expected at two or three sites where a trend was identified (the null hypothesis of no trend is rejected) that no real trend would exist. The reverse case also is possible: for several sites, there could be a real trend but the null hypothesis was not rejected because the trend was not large enough to detect given the noise of the observed data. The probabilities for the reverse case were not determined for this study.

\section{Computations of Trends and Detailed Loads for 1975 to 2004}

To place trends found for 1993-2004 into a longer term context, all of the sites with sufficient data, defined as sites with a minimum of approximately 200 observations from 1975 to 2004 and that had data that covered most of the extended period with some gaps, were analyzed for long-term changes in flow-adjusted concentrations (FAC). In addition, data from the six long-term site subset described in detail previously in the section "Final Site and Sample Selection" were analyzed for long-term changes in loads from 1975 to 2004. Long-term changes in FAC and loads were assessed using the QWTREND program (Vecchia, 2003a, 2005) and the LOADEST program (Runkel and others, 2004). QWTREND uses a time-series model for estimating trends in FAC. The basic form of the model is

$$
F A C=\text { Intercept }+ \text { Annual }+ \text { Seasonal }+ \text { Trend }+H F V
$$

where

FAC is the log of the flow-adjusted concentration;

Intercept is the intercept term;

Annual is the annual streamflow-related anomaly composed of 5-year and 1-year moving average streamflow anomalies; 


\section{Seasonal is the seasonal streamflow-related anomalies, composed of a 3-month moving average streamflow anomaly and second-order Fourier terms that describe seasonal variation; \\ Trend is the trend component that can include trend terms based on time or ancillary variables that explain the trend; and \\ $H F V$ is the high-frequency variability component that includes the high-frequency component of streamflow, which is the daily fluctuations after the longer term anomalies have been removed, and periodic autoregressive coefficients to remove the non-random fluctuation in the observed concentration data.}

Vecchia (2000) describes the estimation of the time-series parameters, and Vecchia (2003b) describes the computation of the anomalies.

The suggested minimum data requirements for QWTREND (Vecchia, 2000) are (1) minimum water-quality record length of 15 years, (2) average of at least four samples per year, (3) at least 10 samples within each quarter of the year, (4) less than 10 percent censored data, and (5) complete streamflow record for the water-quality record for the period of interest plus the preceding 5 years. These minimum data requirements do not guarantee convergence of the program, therefore, an average of at least 6.5 samples per year were required for this analysis. The long-term analysis covered 30 years; therefore, about 200 samples were required for each site. For some sites, slightly less than 200 samples were used because not all constituents were quantified on any given sampling day.

QWTREND was used to determine when changes in the trend during the 1975-2003 period were statistically significant. Once these changes were identified, the nine different predefined regression models (table 3 ) were examined for each trend period and the best load model identified by AIC was computed using LOADEST. The time variable in the model was then used to identify changes in the FAC. Total annual loads, computed by summing daily loads, were then computed for 1975-2003 by use of the various models specified for FAC and the use of LOADEST. Annual loads were calculated for each calendar year. Because streamflow data were not assembled for the period from October through December 2004, the annual loads for 2004 were not estimated. The LOESS smoothing procedure in S-PLUS (Insightful, 2005) was then used to identify the time-weighted central tendency, or moving average, of the total annual loads.

It should be noted that the methodology used to evaluate long-term trends is insensitive to changes in the variability of streamflow or to changes in the unexplained variability of water quality. Both of these changes potentially result in trends in water quality arising from nonlinearity in the specification of the water-quality model. Accommodation of the effects of these uncertainties awaits future research.

\section{Explanation of Observed Trends}

Implications from the analysis of the influence of human activity on trends in constituents were generally based on broad regional patterns rather than the results of specific analyses. These general tendencies were not analyzed on a statistical basis - no test for regional trend was made.

In addition to comparing patterns in the changes in concentrations and loads with the changes in the inputs, a regression approach was used to relate likely sources of nutrients to the observed trends. Changes in fertilizer inputs (fig. 7) were used as an ancillary variable in the trend analysis of the agricultural sites, and annual inputs from fertilizers and atmospheric deposition (figs. 7 and 9) were used as ancillary variables in the analysis of trends of the forested sites. For these ancillary variables, the data were log-transformed and included in the regression models as a substitute for the time term. The model used for each site was similar to the water-quality model and is shown in tables presented for each constituent in the section "Trends in Nutrient and SuspendedSediment Concentrations and Loads." If the p-value of the ancillary variable was less than 0.10 , then it was deemed significant and a plausible candidate to explain the trend in the context of human activity. Because manure input data were available only at 5 -year intervals, those data could not be used in the regression model approach. To assess the change in concentration with the change in manure input for agricultural sites, the changes in manure input were compared to the changes in concentration at each site, and the significance of the relation was assessed using the p-value from the Spearman rank correlation test (Helsel and Hirsch, 2002).

\section{Trends in Streamflow}

Daily streamflows were obtained for the USGS gaging stations at the 49 sites and were analyzed for upward or downward monotonic trends from 1993 to 2004 . The p-values in table 4 indicate the significance of the trend term and are used in figure 12 to demonstrate the significance of the trend $(\mathrm{p}<0.05,0.05 \leq \mathrm{p}<0.10$, and $\mathrm{p} \geq 0.10)$. The trends in streamflow throughout the study area showed a general pattern: small changes in streamflow in the western part, significant decreases in streamflow throughout most of the central part, and either no change or slight increases in streamflow in the eastern part of the study area (fig. 12 and summarized in table 4). In the western part of the study area, only one of the eight stations, the most western site, had a significant trend. In the central part, 18 of 31 stations had significant decreases in streamflow. Two of the 10 stations in the eastern part of the study area had significant increases in streamflow. The changes in streamflow are consistent with the changes in precipitation that occurred throughout this area during this period (fig. 4). 
Table 4. Summary of results for analyses of trends in streamflow at selected sites in the study area, 1993 to 2004.

[USGS, U.S. Geological Survey; ID, identification; $\mathrm{m}^{3} / \mathrm{s}$, cubic meter per second; $\mathrm{ft}^{3} / \mathrm{s}$, cubic foot per second; $\% / y r$, percent per year; sites in bold indicate long-term evaluation sites]

\begin{tabular}{|c|c|c|c|c|c|}
\hline \multirow{2}{*}{$\begin{array}{l}\text { USGS site } \\
\text { number }\end{array}$} & \multirow{2}{*}{$\begin{array}{l}\text { State- } \\
\text { ID number } \\
\text { (figure 1) }\end{array}$} & \multicolumn{2}{|c|}{ Reference flow } & \multirow{2}{*}{$\begin{array}{l}\text { Trend } \\
(\% / y r)\end{array}$} & \multirow[b]{2}{*}{ p-value } \\
\hline & & $\left(\mathrm{m}^{3} / \mathrm{s}\right)$ & $\left(f t^{3} / s\right)$ & & \\
\hline \multicolumn{6}{|c|}{ Western part } \\
\hline 05056100 & ND-1 & 0.30 & 10.6 & -4.90 & 0.435 \\
\hline 05056200 & ND-2 & .53 & 18.7 & -6.87 & .169 \\
\hline 05056239 & ND-3 & .56 & 19.9 & -6.50 & .169 \\
\hline 05058700 & ND-4 & 7.22 & 255 & -2.47 & .387 \\
\hline 05064500 & MN-5 & 62.8 & 2,220 & -1.70 & .406 \\
\hline 05082500 & ND-6 & 120 & 4,250 & -2.63 & .173 \\
\hline 05114000 & ND-7 & .17 & 5.89 & 45.28 & .085 \\
\hline 05120000 & ND-8 & 1.17 & 41.4 & 5.35 & .496 \\
\hline \multicolumn{6}{|c|}{ Central part } \\
\hline 04063700 & WI-9 & 2.64 & 93.3 & -2.99 & 0.004 \\
\hline 04067500 & WI-10 & 75.2 & 2,660 & -.03 & .977 \\
\hline 04073468 & WI-11 & .85 & 29.9 & -2.29 & .321 \\
\hline 04085427 & WI-12 & 4.19 & 148 & -2.71 & .256 \\
\hline 04087000 & WI-13 & 10.2 & 362 & -1.44 & .386 \\
\hline 05287890 & $\mathrm{MN}-14$ & .71 & 25.2 & -5.44 & .028 \\
\hline 05340500 & WI-15 & 116 & 4,080 & -1.09 & .282 \\
\hline 05369500 & WI-16 & 206 & 7,270 & -1.25 & .285 \\
\hline 05382000 & WI-17 & 45.9 & 1,620 & -3.41 & .002 \\
\hline 05389400 & IA-18 & .79 & 27.8 & -4.36 & .000 \\
\hline 05389500 & IA-19 & 1,320 & 46,600 & -2.97 & .001 \\
\hline 05407000 & WI-20 & 264 & 9,330 & -2.26 & .006 \\
\hline 05420500 & IA-21 & 1,860 & 65,800 & -3.22 & .000 \\
\hline 05427718 & WI-22 & .73 & 25.7 & -2.73 & .001 \\
\hline 05427948 & WI-23 & .09 & 3.18 & -.51 & .677 \\
\hline 054310157 & WI-24 & .04 & 1.38 & .26 & .917 \\
\hline 05465500 & IA-25 & 286 & 10,100 & -4.84 & .005 \\
\hline 05474000 & IA-26 & 63.8 & 2,260 & -5.89 & .012 \\
\hline 05481650 & IA-27 & 99.5 & 3,520 & -6.63 & .000 \\
\hline 05500000 & MO-28 & 4.05 & 143 & -6.27 & .020 \\
\hline 05514500 & MO-29 & 3.53 & 125 & -.51 & .924 \\
\hline 05525500 & IL-30 & 4.56 & 161 & -2.94 & .440 \\
\hline 05531500 & IL-31 & 3.84 & 136 & -.48 & .676 \\
\hline 05532500 & IL-32 & 16.3 & 576 & -1.56 & .261 \\
\hline 05540275 & IL-33 & .18 & 6.40 & -3.43 & .119 \\
\hline 05543500 & IL-34 & 302 & 10,700 & -3.84 & .001 \\
\hline 05552500 & IL-35 & 60.0 & 2,120 & -3.65 & .008 \\
\hline 05570000 & IL-36 & 30.1 & 1,060 & -5.68 & .008 \\
\hline 05586100 & IL-37 & 785 & 27,800 & -4.71 & .001 \\
\hline 07014500 & MO-38 & 35.4 & 1,250 & -4.89 & .000 \\
\hline 07018100 & MO-39 & 14.7 & 521 & -4.61 & .002 \\
\hline
\end{tabular}


Table 4. Summary of results for analyses of trends in streamflow at selected sites in the study area, 1993 to 2004.-Continued

[USGS, U.S. Geological Survey; ID, identification; $\mathrm{km}^{2}$, square kilometer; $\mathrm{m}^{3} / \mathrm{s}$, cubic meter per second; $\mathrm{ft}^{3} / \mathrm{s}$, cubic foot per second; \%/yr, percent per year; sites in bold indicate long-term evaluation sites]

\begin{tabular}{|c|c|c|c|c|c|}
\hline \multirow{2}{*}{$\begin{array}{l}\text { USGS site } \\
\text { number }\end{array}$} & \multirow{2}{*}{$\begin{array}{l}\text { State- } \\
\text { ID number } \\
\text { (figure 1) }\end{array}$} & \multicolumn{2}{|c|}{ Reference flow } & \multirow{2}{*}{$\begin{array}{l}\text { Trend } \\
(\% / y r)\end{array}$} & \multirow[b]{2}{*}{ p-value } \\
\hline & & $\left(\mathrm{m}^{3} / \mathrm{s}\right)$ & $\left(\mathbf{f t} \mathrm{t}^{3} / \mathbf{s}\right)$ & & \\
\hline \multicolumn{6}{|c|}{ Eastern part } \\
\hline 03085000 & PA-40 & 210 & 7,410 & 2.48 & 0.275 \\
\hline 03267900 & $\mathrm{OH}-41$ & 4.76 & 168 & 26.87 & .000 \\
\hline 03353637 & IN-42 & .27 & 9.42 & -2.79 & .364 \\
\hline 04186500 & $\mathrm{OH}-43$ & 2.37 & 83.9 & -.34 & .928 \\
\hline 04193500 & OH-44 & 59.7 & 2,110 & .57 & .847 \\
\hline 0422026250 & NY-45 & .20 & 7.00 & 5.90 & .031 \\
\hline 04232034 & NY-46 & .83 & 29.4 & -.91 & .464 \\
\hline 0423204920 & NY-47 & .15 & 5.28 & -1.99 & .274 \\
\hline 0423205025 & NY-48 & 3.04 & 108 & -2.04 & .153 \\
\hline 04237946 & NY-49 & .02 & .69 & .31 & .841 \\
\hline
\end{tabular}

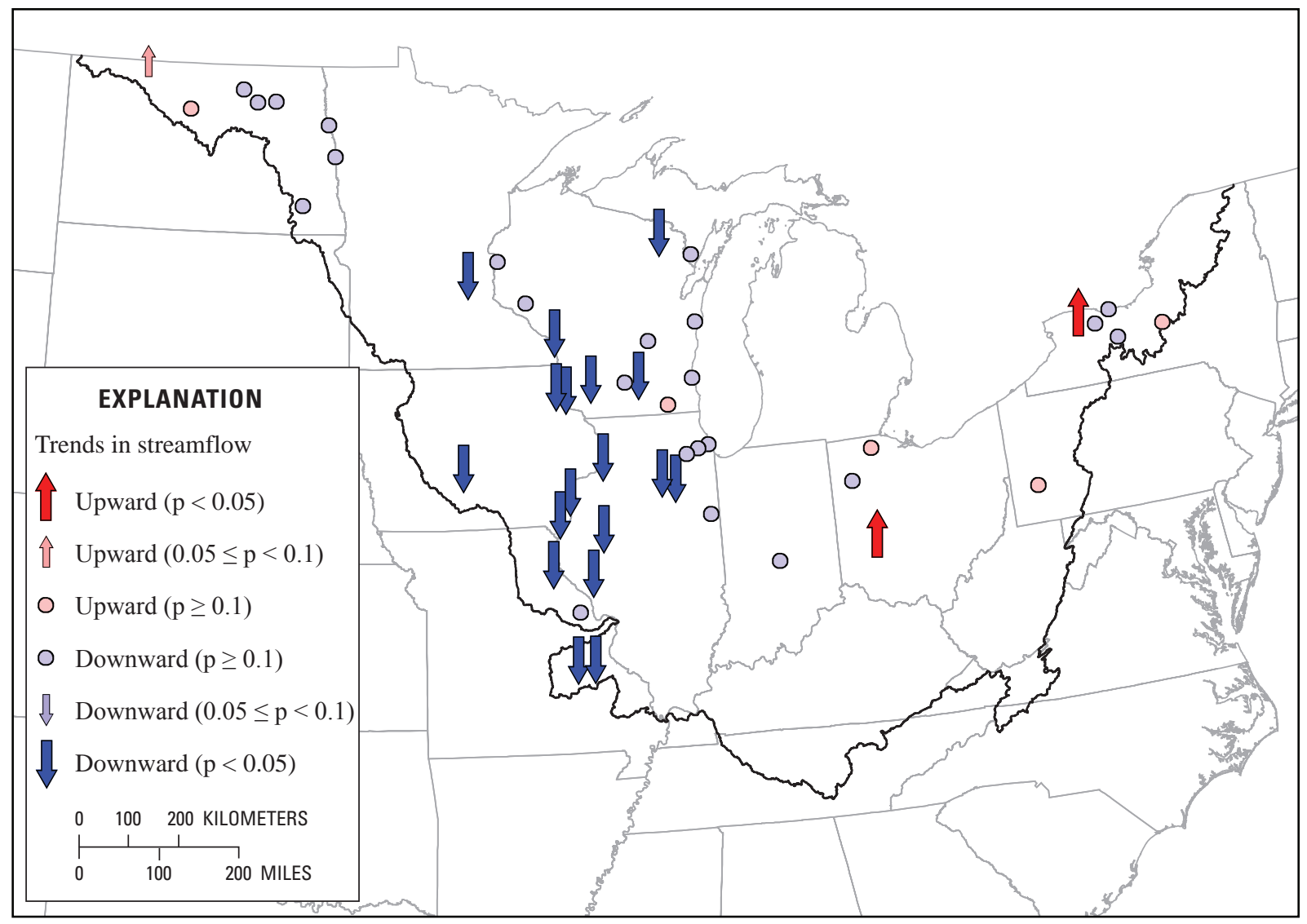

Figure 12. Trends in streamflow from 1993 to 2004 throughout the study area. 
Long-term records in streamflow from 1975 to 2003 can be used to understand trends in streamflow from 1993 to 2004. The shorter term trends can be compared to the longer term trends and variability. Long-term trends in streamflow were examined at 6 of the 49 sites (fig. 13). For each site, mean annual streamflows were computed as the average of the mean daily streamflows, and then a LOESS smoothing procedure was used to indicate the long-term trends in mean annual streamflows.

Streamflow trends from 1993 to 2004 observed at each of the six long-term sites agree with the general trend for that period as shown in figure 13. For all sites except the Souris River, the range and variability of streamflow during the shortterm period matched the range and variability of streamflow during the long-term period. The Souris River shows a period from 1984 to 1995 when the annual mean daily streamflow never exceeded $4 \mathrm{~m}^{3} / \mathrm{s}$. There could be some effect from that period on the trends estimated at that site.

\section{Trends in Nutrient and Suspended- Sediment Concentrations and Loads}

For each constituent, the trends in concentrations and loads are summarized in a table and shown spatially in a figure. The FA and OA trends in concentrations and trends in loads represent the monotonic trend from 1993 to 2004 and are expressed as a change in percentage per year and as a change in milligrams per liter per year or kilograms per year. The $\mathrm{p}$-values in the tables indicate the significance of the trend term and are used in the figure to demonstrate the significance of the trend $(p<0.05,0.05 \leq p<0.10$, and $p \geq 0.10)$. The reference concentration and load in the tables are typical values for that site in the beginning of the period and do not represent a summary statistic such as a mean or median value.

\section{Total Nitrogen}

\section{General Patterns in Total Nitrogen Concentrations and Yields}

From 1970 to 2004, median midmonthly total nitrogen (TN) concentrations across the study area ranged from 0.102 to $206 \mathrm{mg} / \mathrm{L}$. The overall mean and median values of the median concentrations at these sites were 2.65 and $1.70 \mathrm{mg} / \mathrm{L}$, respectively. The highest concentrations were in the western, southwestern, and south-central parts of the study area (fig. 14A). The lowest concentrations were mostly in northern Wisconsin and Michigan and in the northeastern and southeastern parts of the study area. The highest concentrations were in areas with intensive agriculture, and the lowest concentrations were in forested areas (fig. 5). Median midmonthly
$\mathrm{TN}$ concentrations at the 24 trend sites, based on water-quality data from 1993 to 2004, ranged from 0.314 to $6.22 \mathrm{mg} / \mathrm{L}$. The distribution in concentrations at these sites was consistent with that in figure 14A. The mean and median values of the median concentrations at the trend sites were 2.07 and $1.41 \mathrm{mg} / \mathrm{L}$, respectively.

Median annual TN yields, expressed as loads per unit area, ranged from about 2.36 to $18,300 \mathrm{~kg} / \mathrm{km}^{2}$ based on water-quality and streamflow data from 1970 to 2004 . The overall mean and median values of the median yields at these sites were 1,280 and $771 \mathrm{~kg} / \mathrm{km}^{2}$, respectively. The highest yields were throughout the middle of the study area (fig. 14B). The lowest yields were throughout the northern part of the study area. The highest yields were in areas with intense agriculture and moderate runoff. The areas with the highest runoff had relatively low TN concentrations, such as in northern Wisconsin and southeastern parts of the study area. The major difference in the distributions between concentrations and yields was in the northwestern part of the study area, which had high concentrations but low yields. Median annual TN yields at the trend sites ranged from 12 to $3,310 \mathrm{~kg} / \mathrm{km}^{2}$ (table 5), based on water-quality and streamflow data from 1993 to 2004 . The mean and median values of the median yields from each site were 753 and $446 \mathrm{~kg} / \mathrm{km}^{2}$, respectively. The distribution in yields was consistent with yields shown in figure $14 \boldsymbol{B}$.

\section{Trends in Total Nitrogen Concentrations}

From 1993 to 2004, the FA trends in TN concentrations at 19 of the 24 sites that had sufficient data for analysis show a tendency toward increasing concentrations (table 5; fig. 15A). The 19 sites with increasing TN concentrations were distributed throughout the entire study area; however, only 9 of these sites had significant upward trends $(\mathrm{p}<0.10)$ and were all located in the central part of the study area. These upward FA trends indicate that the effects of anthropogenic activities are continuing to increase in these areas and add additional TN to the streams. Only two of the five sites that had downward trends in concentrations had significant trends; those sites were Spring Brook in northern Illinois in the central part, and Red River of the North in the western part of the study area.

When the OA trends in TN concentrations were examined for the period 1993-2004, 16 of the 24 sites showed a general tendency toward increasing concentrations (table 5; fig. 15B); however, only three of these sites had significant upward trends - two sites in southern Wisconsin in the central part of the study area and one site in North Dakota the western part of the study area. Of the eight sites with a downward trend, only two sites had significant trends - the same two sites that had downward FA trends. The sites with downward trends in concentrations were scattered throughout the study area, indicating no regional trend. 
A.

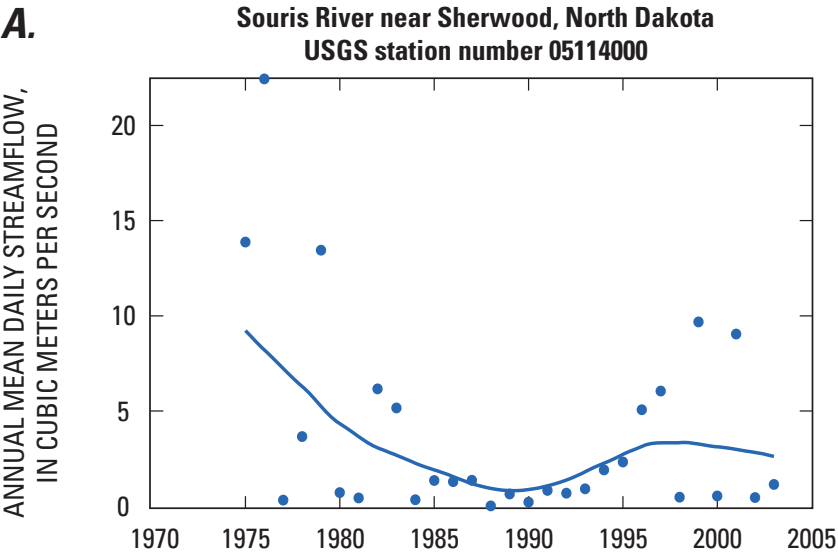

C.

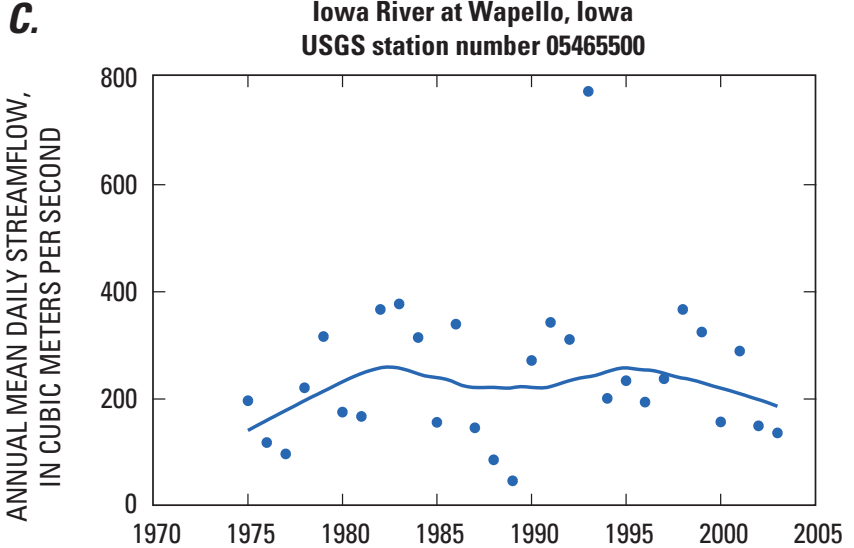

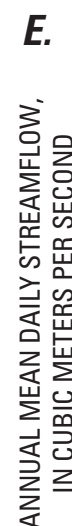

Maumee River at Waterville, Ohio USGS station number 04193500

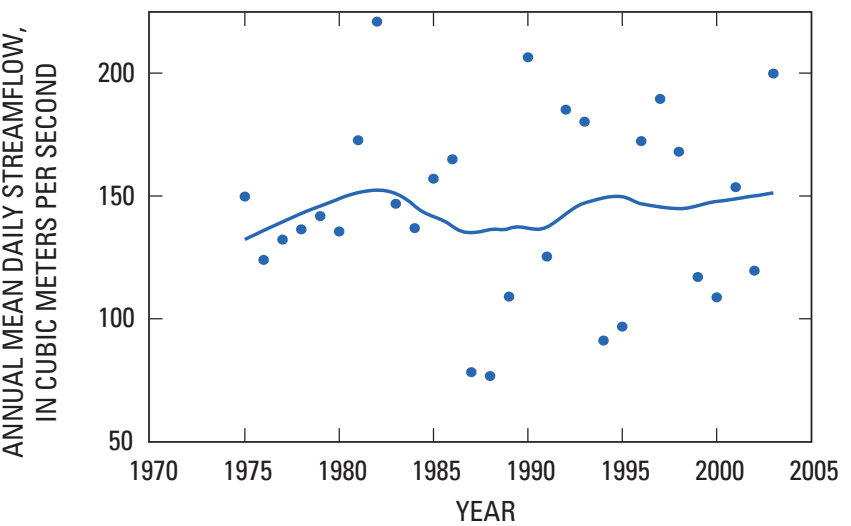

B.

Chippewa River at Durand, Wisconsin USGS station number 05369500

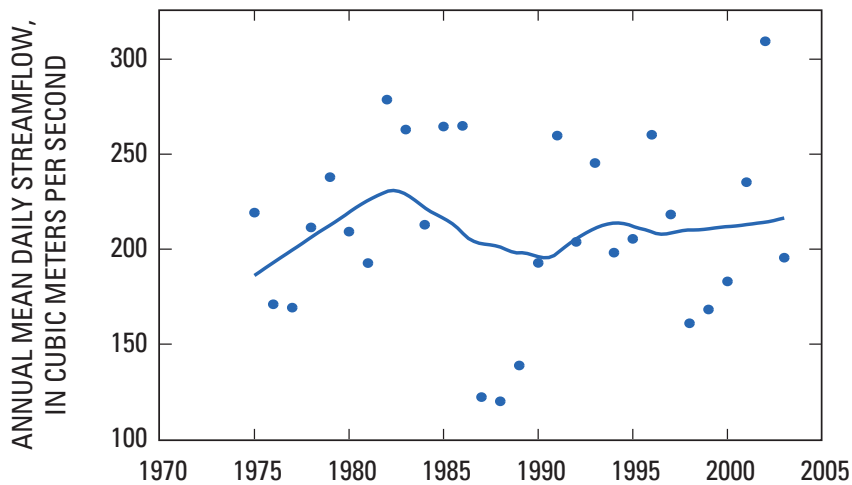

D.

Milwaukee River at Milwaukee, Wisconsin USGS station number 04087000

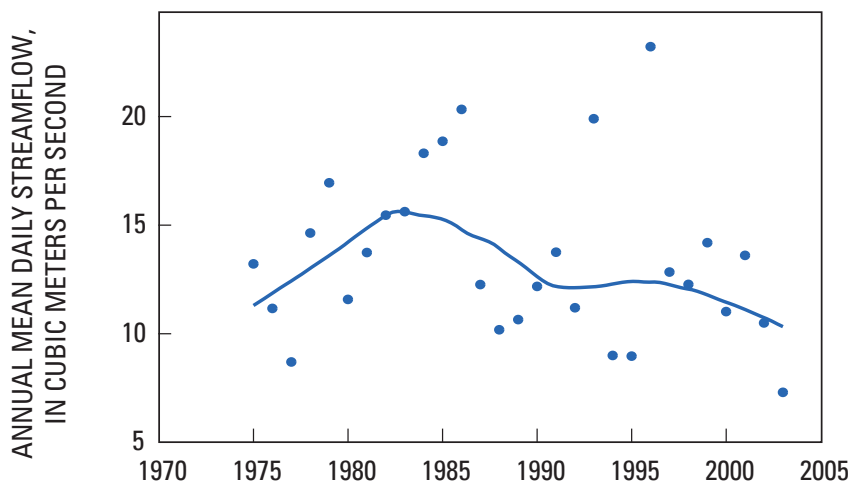

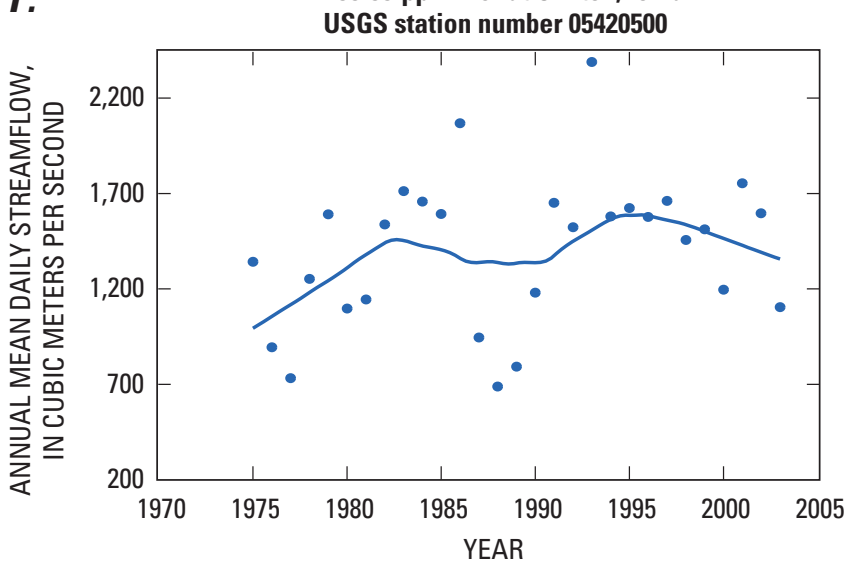

EXPLANATION

- LOESS smoothing line

- Annual flow

Figure 13. Long-term trends in streamflow from 1975 to 2003 at six selected sites in the study area. 


\section{A. Median total nitrogen concentration}

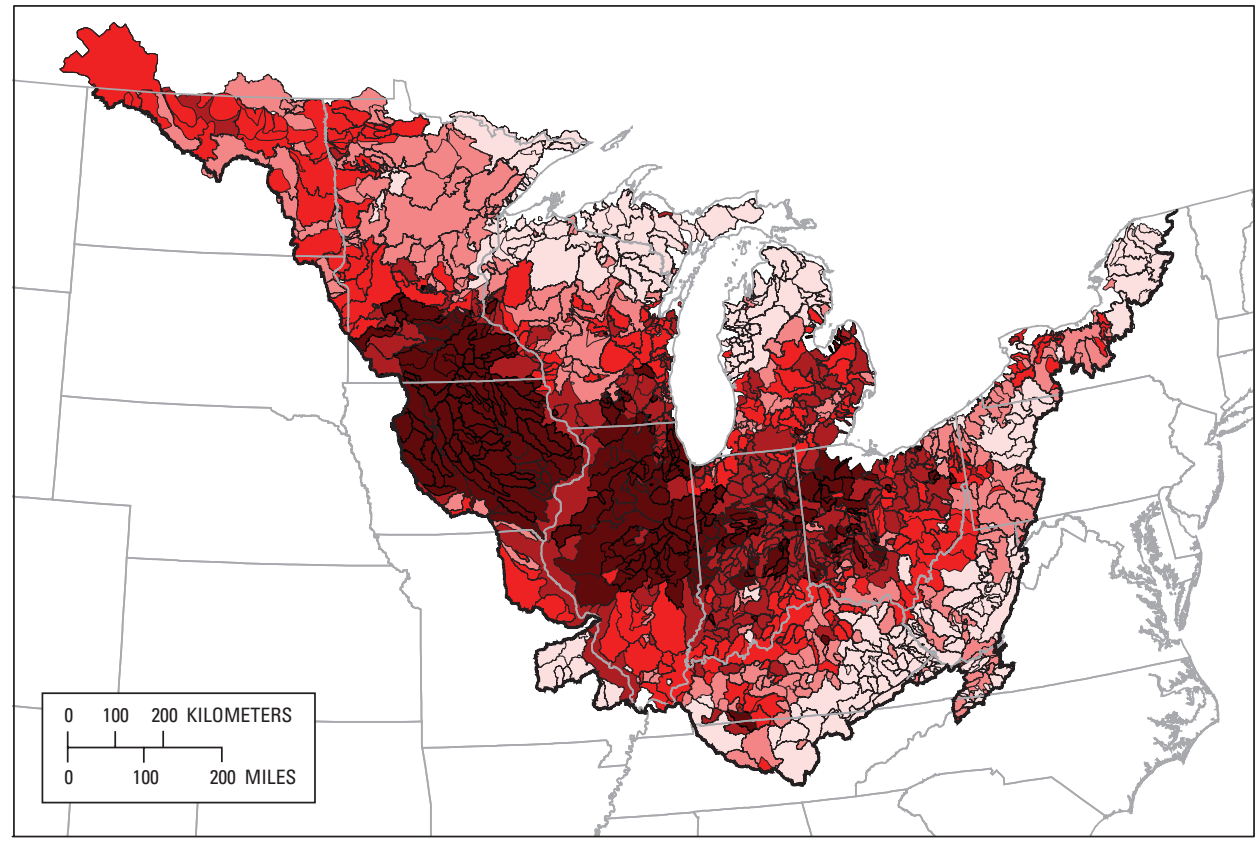

\section{EXPLANATION}

Median total nitrogen concentration, in milligrams per liter

$\square 0.102-0.774$
$\square 0.775-1.34$
$\square$
$1.35-2.20$
$2.21-4.21$
$4.22-206$

$-\quad$ Study area
$-\quad$ State boundary
$-\quad$ Basin boundary

\section{B. Median annual total nitrogen yield}

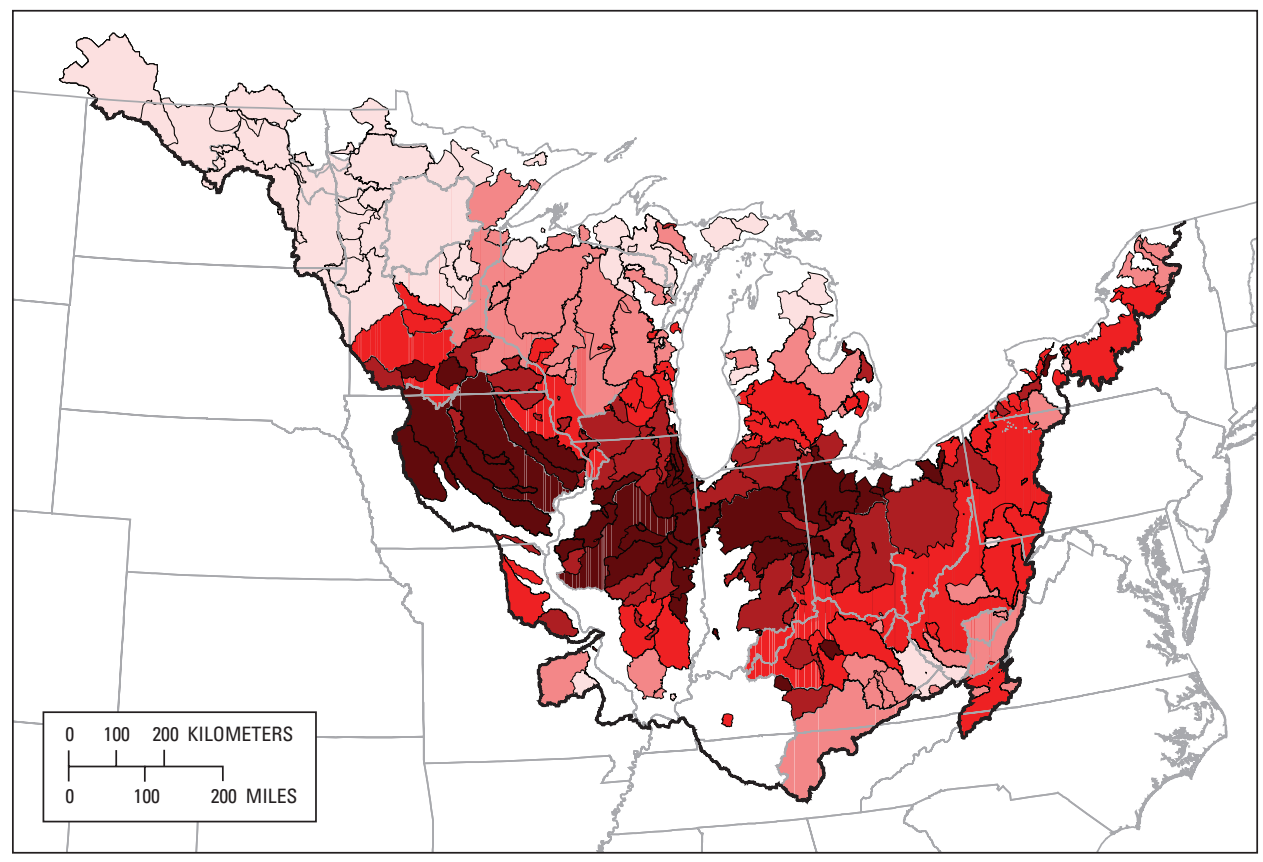

\section{EXPLANATION}

Median annual total nitrogen yield, in kilograms per square kilometer
$\square 2.36-302$
$\square 303-555$
$556-947$
$948-1,970$
- $1,971-18,300$
- Study area
- State boundary
- Basin boundary

Figure 14. Spatial patterns from 1970 to 2004 in $\boldsymbol{A}$, median total nitrogen concentrations and $\boldsymbol{B}$, median annual total nitrogen yields throughout the study area. 
Table 5. Summary of results for analyses of flow-adjusted trends, overall trends, and trends in loads for total nitrogen (TN, USGS parameter code 00600 ), 1993 to 2004.

[USGS, U.S. Geological Survey; ID, identification; mg/L, milligram per liter; mg/L/yr, milligram per liter per year; \%/yr, percent per year; kg, kilogram; kg/km², kilogram per square kilometer; $\mathrm{kg} / \mathrm{yr}$, kilogram per year; NA, not available; NC, not calculated; sites in bold indicate long-term evaluation sites]

\begin{tabular}{|c|c|c|c|c|c|c|c|c|c|c|c|c|c|c|c|}
\hline \multirow{3}{*}{$\begin{array}{l}\text { USGS } \\
\text { site } \\
\text { number }\end{array}$} & \multirow{3}{*}{$\begin{array}{c}\text { State-ID } \\
\text { number } \\
\text { (figure 1) }\end{array}$} & \multirow{3}{*}{$\begin{array}{c}\text { Water- } \\
\text { quality } \\
\text { model } \\
\text { (table 3) }\end{array}$} & \multicolumn{7}{|c|}{ Concentration } & \multirow{2}{*}{\multicolumn{6}{|c|}{ Annual loads }} \\
\hline & & & \multicolumn{4}{|c|}{ Flow-adjusted trend } & \multicolumn{3}{|c|}{ Overall trend } & & & & & & \\
\hline & & & $\begin{array}{c}\text { Reference } \\
\text { concentration } \\
\text { (mg/L) }\end{array}$ & $\begin{array}{c}\text { Trend } \\
\text { (mg/L/yr) }\end{array}$ & $\begin{array}{l}\text { Trend } \\
(\% / y r)\end{array}$ & p-value & $\begin{array}{c}\text { Trend } \\
\text { (mg/L/yr) }\end{array}$ & $\begin{array}{l}\text { Trend } \\
(\% / y r)\end{array}$ & p-value & $\begin{array}{c}\text { Median } \\
\text { annual load } \\
(\mathrm{kg})\end{array}$ & $\begin{array}{c}\text { Median } \\
\text { yield } \\
\left(\mathbf{k g} / \mathbf{k m}^{2}\right)\end{array}$ & $\begin{array}{c}\text { Reference } \\
\text { load } \\
(\mathbf{k g})\end{array}$ & $\begin{array}{c}\text { Trend } \\
(\mathrm{kg} / \mathrm{yr})\end{array}$ & $\begin{array}{l}\text { Trend } \\
\text { (\%/yr) }\end{array}$ & p-value \\
\hline \multicolumn{16}{|c|}{ Western part } \\
\hline 05056100 & ND-1 & 9 & 1.284 & 0.061 & 4.76 & 0.110 & 0.086 & 6.71 & 0.080 & NA & NA & 12,500 & -250 & -1.96 & 0.784 \\
\hline 05056200 & ND-2 & 7 & 1.727 & .037 & 2.15 & .325 & .046 & 2.66 & .223 & NA & NA & 28,800 & $-1,800$ & -6.35 & .249 \\
\hline 05056239 & ND-3 & 7 & 1.749 & .025 & 1.45 & .637 & .032 & 1.81 & .570 & NA & NA & 31,800 & $-1,900$ & -6.08 & .251 \\
\hline 05058700 & ND-4 & 3 & 1.233 & .025 & 2.05 & .499 & .015 & 1.18 & .689 & 747,000 & 116 & 281,000 & $-4,600$ & -1.65 & .714 \\
\hline 05082500 & ND-6 & 7 & 1.513 & -.062 & -4.08 & .075 & -.067 & -4.43 & .038 & $8,460,000$ & 860 & $5,940,000$ & $\mathrm{NC}$ & -5.77 & .022 \\
\hline 05114000 & ND-7 & 9 & 2.012 & -.024 & -1.20 & .298 & -.029 & -1.42 & .256 & 106,000 & 13.5 & 11,000 & 3,820 & 34.64 & .119 \\
\hline 05120000 & ND-8 & 7 & 1.474 & .007 & .45 & .742 & .011 & .72 & .623 & 136,000 & 12.0 & 55,600 & 3,590 & 6.45 & .463 \\
\hline \multicolumn{16}{|c|}{ Central part } \\
\hline 04063700 & WI-9 & 9 & 0.447 & 0.006 & 1.43 & 0.061 & 0.001 & 0.14 & 0.860 & 61,400 & 171 & 37,200 & $-1,100$ & -2.93 & 0.052 \\
\hline 04067500 & WI-10 & 3 & .428 & -.001 & -.02 & .991 & -.001 & -.03 & .986 & $1,330,000$ & 131 & $1,020,000$ & -670 & -.07 & .978 \\
\hline 04087000 & WI-13 & 7 & 1.735 & .045 & 2.61 & .000 & .043 & 2.48 & .000 & $1,030,000$ & 570 & 562,000 & 3,520 & .63 & .764 \\
\hline 05287890 & $\mathrm{MN}-14$ & 9 & 1.251 & .024 & 1.96 & .032 & -.005 & -.41 & .743 & 72,100 & 323 & 25,700 & $-1,500$ & -5.80 & .068 \\
\hline 05340500 & WI-15 & 9 & .539 & .001 & .15 & .943 & -.001 & -.28 & .893 & $3,180,000$ & 197 & $1,970,000$ & $-27,000$ & -1.37 & .566 \\
\hline 05369500 & WI-16 & 7 & 1.213 & .022 & 1.85 & .003 & .024 & 2.01 & .002 & $10,000,000$ & 428 & $7,900,000$ & 36,500 & .46 & .724 \\
\hline 05382000 & WI-17 & 7 & 1.243 & .018 & 1.43 & .061 & .013 & 1.08 & .138 & $2,400,000$ & 446 & $1,800,000$ & $-50,000$ & -2.79 & .043 \\
\hline 05407000 & WI-20 & 7 & 1.354 & .023 & 1.67 & .104 & .020 & 1.46 & .111 & $12,300,000$ & 456 & $11,300,000$ & $-140,000$ & -1.20 & .328 \\
\hline 05420500 & IA-21 & 5 & 2.096 & .054 & 2.56 & .079 & .010 & .46 & .730 & $131,000,000$ & 591 & $118,000,000$ & $-3,500,000$ & -2.98 & .058 \\
\hline 05465500 & IA-25 & 8 & 5.804 & .250 & 4.30 & .008 & .061 & 1.04 & .519 & $63,300,000$ & 1,950 & $52,700,000$ & $-2,400,000$ & -4.60 & .093 \\
\hline 05540275 & IL-33 & 7 & 1.599 & -.043 & -2.72 & .002 & -.053 & -3.32 & .000 & 20,800 & 810 & 9,200 & -500 & -5.43 & .016 \\
\hline 05586100 & IL-37 & 9 & 3.978 & .149 & 3.75 & .016 & .060 & 1.51 & .292 & $137,000,000$ & 1,970 & $89,300,000$ & $-3,800,000$ & -4.25 & .051 \\
\hline 07018100 & MO-39 & 3 & .307 & .007 & 2.42 & .609 & -.003 & -.91 & .826 & 606,000 & 318 & 125,000 & $-6,600$ & -5.30 & .147 \\
\hline
\end{tabular}


Table 5. Summary of results for analyses of flow-adjusted trends, overall trends, and trends in loads for total nitrogen (TN, USGS parameter code 00600 ), 1993 to 2004.-Continued

[USGS, U.S. Geological Survey; ID, identification; mg/L, milligram per liter; mg/L/yr, milligram per liter per year; \%/yr, percent per year; $\mathrm{kg}$, kilogram; $\mathrm{kg} / \mathrm{km}^{2}$, kilogram per square kilometer; $\mathrm{kg} / \mathrm{yr}$, kilogram per year; NA, not available; $\mathrm{NC}$, not calculated; sites in bold indicate long-term evaluation sites]

\begin{tabular}{|c|c|c|c|c|c|c|c|c|c|c|c|c|c|c|c|}
\hline \multirow{3}{*}{$\begin{array}{l}\text { USGS } \\
\text { site } \\
\text { number }\end{array}$} & \multirow{3}{*}{$\begin{array}{c}\text { State-ID } \\
\text { number } \\
\text { (figure 1) }\end{array}$} & \multirow{3}{*}{$\begin{array}{c}\text { Water- } \\
\text { quality } \\
\text { model } \\
\text { (table 3) }\end{array}$} & \multicolumn{7}{|c|}{ Concentration } & \multirow{2}{*}{\multicolumn{6}{|c|}{ Annual loads }} \\
\hline & & & \multicolumn{4}{|c|}{ Flow-adjusted trend } & \multicolumn{3}{|c|}{ Overall trend } & & & & & & \\
\hline & & & $\begin{array}{c}\text { Reference } \\
\text { concentration } \\
\text { (mg/L) }\end{array}$ & $\begin{array}{l}\text { Trend } \\
\text { (mg/L/yr) }\end{array}$ & $\begin{array}{l}\text { Trend } \\
(\% / y r)\end{array}$ & p-value & $\begin{array}{l}\text { Trend } \\
\text { (mg/L/yr) }\end{array}$ & $\begin{array}{l}\text { Trend } \\
(\% / y r)\end{array}$ & p-value & $\begin{array}{c}\text { Median } \\
\text { annual load } \\
(\mathrm{kg})\end{array}$ & $\begin{array}{c}\text { Median } \\
\text { yield } \\
\left(\mathbf{k g} / \mathbf{k m}^{2}\right)\end{array}$ & $\begin{array}{c}\text { Reference } \\
\text { load } \\
(\mathrm{kg})\end{array}$ & $\begin{array}{c}\text { Trend } \\
(\mathrm{kg} / \mathrm{yr})\end{array}$ & $\begin{array}{l}\text { Trend } \\
(\% / y r)\end{array}$ & p-value \\
\hline \multicolumn{16}{|c|}{ Eastern part } \\
\hline 03085000 & PA-40 & 5 & 0.869 & 0.028 & 3.26 & 0.118 & 0.025 & 2.86 & 0.163 & $13,000,000$ & 682 & $5,810,000$ & 356,000 & 6.13 & 0.058 \\
\hline 03353637 & $\mathrm{IN}-42$ & 7 & 1.048 & -.003 & -.27 & .749 & -.010 & -.97 & .386 & 30,200 & 686 & 8,650 & -310 & -3.53 & .342 \\
\hline 04186500 & $\mathrm{OH}-43$ & 7 & 3.390 & .080 & 2.37 & .421 & .077 & 2.26 & .470 & $2,850,000$ & 3,310 & 260,000 & 4,820 & 1.86 & .754 \\
\hline 04193500 & OH-44 & 9 & 2.908 & .087 & 2.98 & .126 & .093 & 3.20 & .145 & $38,400,000$ & 2,340 & $5,300,000$ & 210,000 & 3.96 & .419 \\
\hline
\end{tabular}




\section{A. Flow-adjusted trend in concentrations}

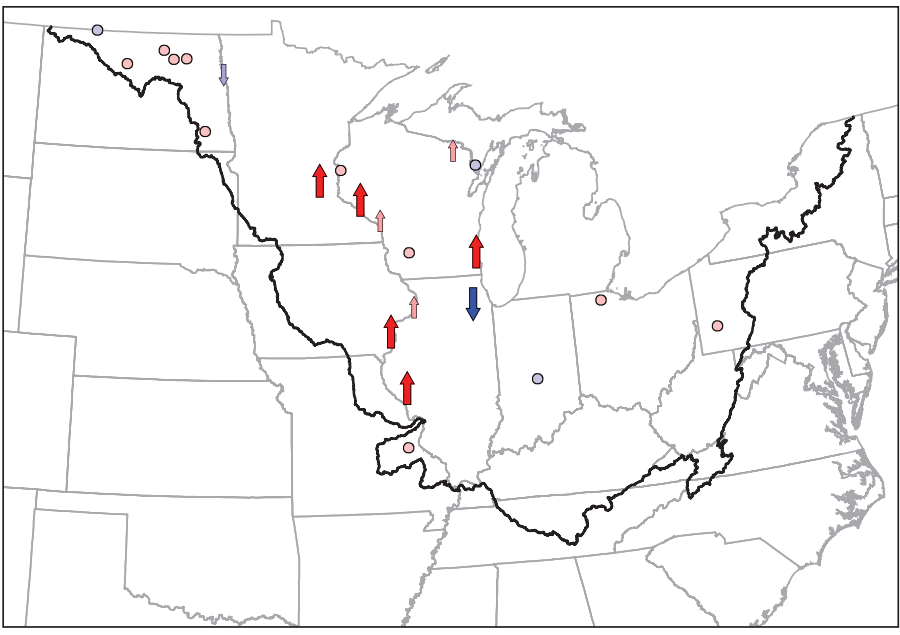

\section{B. Overall trend in concentrations}

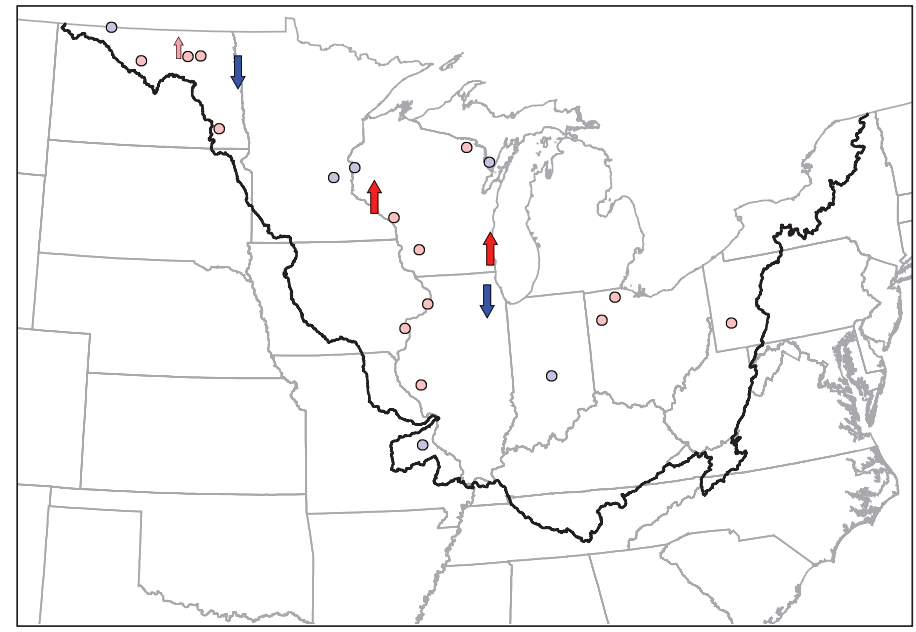

\section{Trend in annual loads}

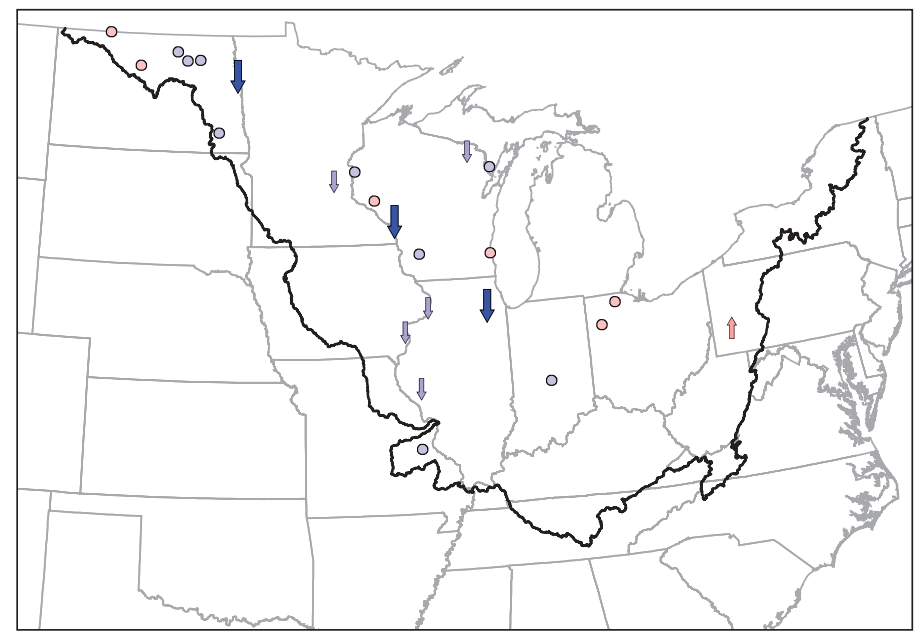

\section{TOTAL NITROGEN}

EXPLANATION

Trends

1 Upward (p < 0.05)

^ Upward $(0.05 \leq \mathrm{p}<0.1)$

○ $\operatorname{Upward}(\mathrm{p} \geq 0.1)$

○ Downward ( $\mathrm{p} \geq 0.1$ )

$\Downarrow$ Downward $(0.05 \leq \mathrm{p}<0.1)$

$\checkmark$ Downward $(\mathrm{p}<0.05)$

$$
\begin{aligned}
& 0 \quad 400 \text { KILOMETERS } \\
& \longmapsto_{0} \prod_{400 \text { MILES }}
\end{aligned}
$$

Figure 15. Trends in total nitrogen from 1993 to 2004 for $\boldsymbol{A}$, flow-adjusted concentrations, $\boldsymbol{B}$, overall concentrations, and $\boldsymbol{C}$, annual loads throughout the study area. 
The differences between FA trends and OA trends in TN concentrations are attributed to the trends in streamflow (fig. 12). The strong downward trends in streamflow in the central part of the study area moderated the upward FA trends in that area. Of the eight sites that had significant upward FA trends in the central part of the study area, six sites had significant downward trends in streamflow, which generally resulted in insignificant OA trends or trends less than about 3 percent per year for those sites where the trends were significant. Sites in the eastern part of the study area did not have significant trends in streamflow and, therefore, the FA and OA trends were similar. The OA trends at sites in the western part of the study area also were not strongly affected by trends in streamflow, except for the Red River of the North (05082500), which had a downward trend in streamflow and a downward FA trend that resulted in a strong downward OA trend in concentrations, significant at $\mathrm{p}<0.05$.

To place the 1993 to 2004 trends in concentration into a longer term context, FA trends were computed using QWTREND from 1975 to 2004 for all of the sites with sufficient data (table 6). The FA trends in TN concentrations had small deviations from average conditions for the Chippewa River (05369500) and Iowa River (05465500) sites, both in the central part of the study area (fig. 16; table 6). The other four long-term sites had larger deviations from the longterm average flow-adjusted concentrations. The Souris River (05114000) site, in the western part, had a downward shift between 1984 and 1992, when no samples were collected. The
Milwaukee River (04087000) had three distinct periods: an upward FA trend from 1975 to 1986 , followed by a downward FA trend until 1991, and an upward FA trend from 1992 to 2004. The only long-term site in the eastern part, the Maumee River (04193500), had no FA trend until 1988, after which the flow-adjusted concentration increased for 2 years, which was followed by a downward FA trend to 2004. The Mississippi River integrator site (05420500) had a significant upward FA trend from 1975 to 1983, after which the flow-adjusted concentration was nearly constant. No consistent long-term FA trends in TN concentrations were found at these sites; changes generally alternated between upward and downward trends. Those fluctuating trends imply that local factors are more important that regional factors for long-term trends.

\section{Trends in Total Nitrogen Loads}

From 1993 to 2004 , TN loads at 17 of the 24 sites that had sufficient data for analysis (table 5; fig. 15C) indicated a spatial tendency toward decreasing loads. Most of the sites with a downward trend were in the central or western parts of the study area. Eight of these sites had significant downward trends in loads $(\mathrm{p}<0.10)$; most of these sites had significant downward trends in streamflow as well (fig. 12). The only exception was the site in eastern North Dakota, which had a significant downward trend in load and no trend in streamflow. Of the seven sites with upward trends in TN loads, only one site, the site in Pennsylvania, had a significant trend.

Table 6. Summary of flow-adjusted trends in total nitrogen concentrations (TN, USGS parameter code 00600) estimated by QWTREND for long-term evaluation sites, 1975 to 2004.

[USGS, U.S. Geological Survey; mg/L, milligram per liter]

\begin{tabular}{|c|c|c|}
\hline $\begin{array}{l}\text { USGS site } \\
\text { number }\end{array}$ & Trend period & Description of flow-adjusted concentration \\
\hline \multirow[t]{3}{*}{05114000} & January 1975-August 1983 & Constant value of $1.88 \mathrm{mg} / \mathrm{L}$ \\
\hline & September 1983-February 1993 & Gap in sampling \\
\hline & March 1993-December 2004 & Upward trend from 1.30 to $1.66 \mathrm{mg} / \mathrm{L}$ \\
\hline 05369500 & January 1975-December 2004 & Upward trend from 1.14 to $1.42 \mathrm{mg} / \mathrm{L}$ \\
\hline 05465500 & January 1975-December 2004 & Downward trend from 6.93 to $6.07 \mathrm{mg} / \mathrm{L}$ \\
\hline \multirow[t]{3}{*}{04087000} & January 1975-December 1986 & Upward trend from 1.86 to $2.00 \mathrm{mg} / \mathrm{L}$ \\
\hline & January 1987-December 1991 & Downward trend from 2.00 to $1.74 \mathrm{mg} / \mathrm{L}$ \\
\hline & January 1992-Dec 2004 & Upward trend from 1.74 to $2.18 \mathrm{mg} / \mathrm{L}$ \\
\hline \multirow[t]{3}{*}{04193500} & January 1975-December 1987 & Constant value of $5.25 \mathrm{mg} / \mathrm{L}$ \\
\hline & January 1988-December 1989 & Upward trend from 5.25 to $6.35 \mathrm{mg} / \mathrm{L}$ \\
\hline & January 1990-December 2004 & Downward trend from 6.35 to $4.02 \mathrm{mg} / \mathrm{L}$ \\
\hline \multirow[t]{2}{*}{05420500} & January 1975-December 1982 & Upward trend from 1.60 to $2.38 \mathrm{mg} / \mathrm{L}$ \\
\hline & January 1983-December 2004 & $\begin{array}{l}\text { Downward trend from } 2.38 \text { to } 2.30 \mathrm{mg} / \mathrm{L} \\
\text { Gap in sampling from October } 1986 \text { to May } 1991 \\
\text { Gap in sampling from August } 1992 \text { to October } 1995\end{array}$ \\
\hline
\end{tabular}


A.

Souris River near Sherwood, North Dakota USGS station number 05114000

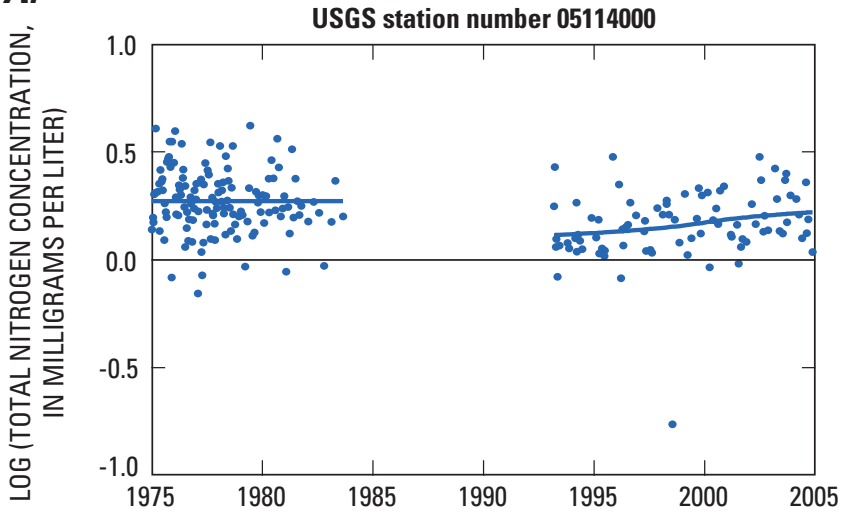

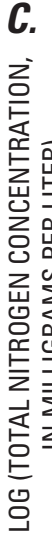

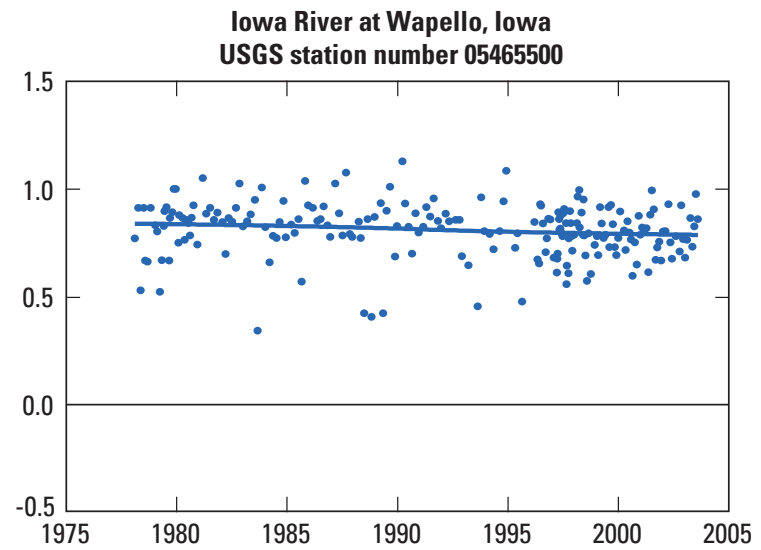

E.

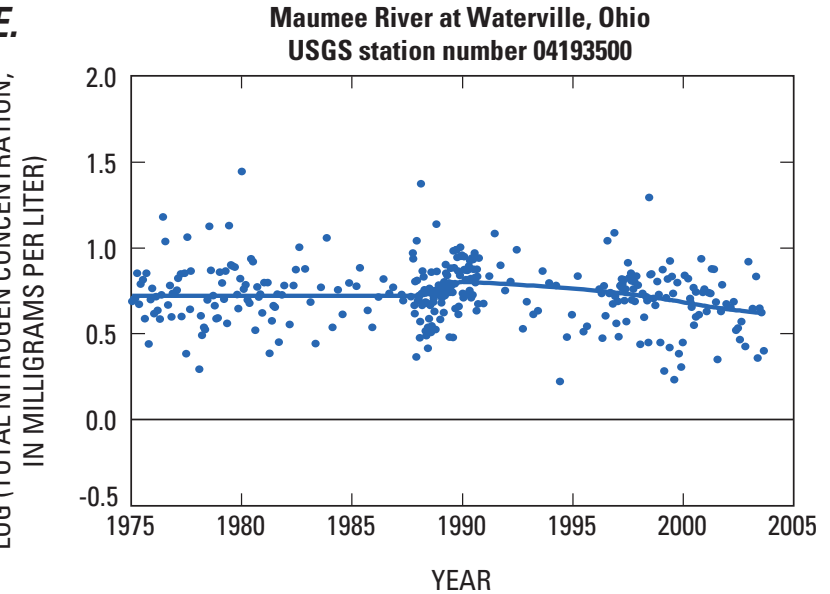

B. Chippewa River at Durand, Wisconsin USGS station number 05369500
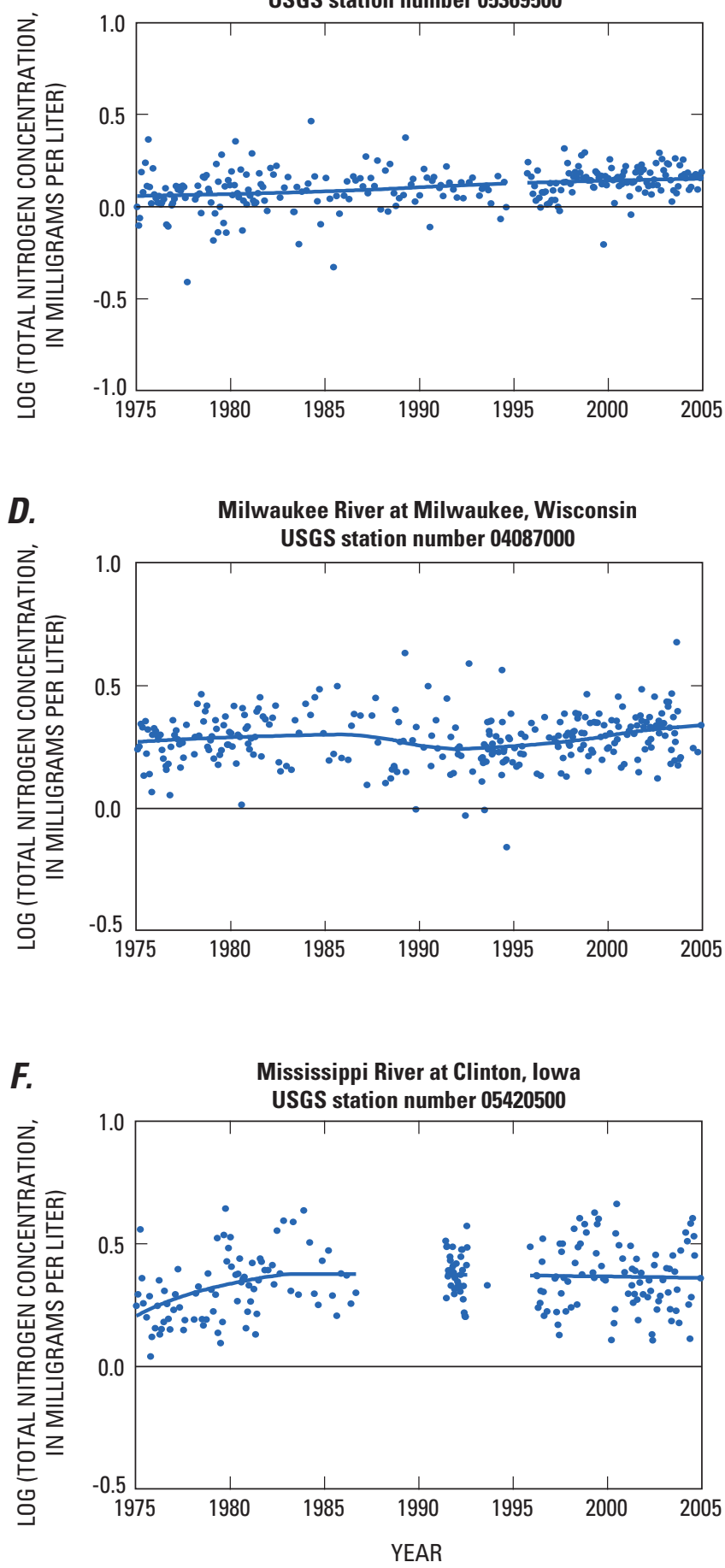

EXPLANATION

- LOESS smoothing line

- Concentration

Figure 16. Long-term flow-adjusted trends in total nitrogen concentrations from 1975 to 2004 at six selected sites in the study area. 
A comparison of the trends in loads and FA trends in concentrations indicates that the trends in loads are driven primarily by streamflow rather than changes in concentrations (fig. 15C). However, the effects of the trends in streamflow can augment the FA trends in concentration to cause a larger OA trend, such as the site in eastern North Dakota (fig. 15B).

Annual loads from 1975 to 2003 at the six long-term sites were used to place these short-term trends in load into a longer term context (fig. 17). The long-term changes at all six sites closely resembled the long-term trend in streamflow (fig. 13), which again indicates the importance of changes in streamflow in driving the trends in loads. This relation between streamflow and TN loads was consistent at all scales, from the relatively small Souris River, N. Dak., with a maximum mean annual streamflow of approximately $23.2 \mathrm{~m}^{3} / \mathrm{s}$, to the Mississippi River at Clinton, Iowa, with a maximum mean annual streamflow of $2,390 \mathrm{~m}^{3} / \mathrm{s}$.

Total nitrogen loads at the Souris River, N. Dak., decreased from the mid-1970s to approximately 1990, when loads increased slightly until 2003. That pattern in loads could have been affected by the construction of dams within the basin. Loads at the Milwaukee River, Wisconsin, generally increased from 1975 to 1985 , then decreased until 1991, and then remained relatively constant through 2004 . Loads at the Maumee River, Ohio, increased from 1975 to about 1982, then decreased slightly through 2003. Loads at the remaining four sites generally increased from 1975 to about 1982, then stayed relatively constant until about 1993, and then increased (Chippewa River) or decreased (Iowa and Mississippi Rivers) slightly until 2003.

\section{Dissolved Ammonia}

\section{General Patterns in Dissolved Ammonia Concentrations and Yields}

Median midmonthly dissolved ammonia (NH4) concentrations at 36 of the 49 trend sites that had sufficient data for analysis ranged from 0.010 to $0.150 \mathrm{mg} / \mathrm{L}$, based on data from 1993 to 2004. The mean and median values of the median NH4 concentrations at these sites were 0.044 and $0.032 \mathrm{mg} / \mathrm{L}$, respectively. The highest concentrations were measured at urban and agricultural sites in central Wisconsin and in central Illinois. Sites with high NH4 concentrations did not form regional patterns, but rather were spatially intermixed with sites with substantially lower concentrations. Although the lowest concentrations were irregularly distributed through the study area, the forested eastern sites in New York had the lowest concentrations.
Median annual NH4 yields at the trend sites ranged from 1.41 to $118 \mathrm{~kg} / \mathrm{km}^{2}$ (table 7), based on data from 1993 to 2004 . The mean and median values from the median yields at these sites were 25.4 and $18.5 \mathrm{~kg} / \mathrm{km}^{2}$, respectively. The highest ammonia yields were at Salt Creek, Ill.; Des Plaines River, Ill.; and Northrup Creek, N.Y. The lowest yields were at the Souris River near Sherwood, N. Dak., the Souris River near Verendrye, N. Dak., and at Irondequoit Creek, N.Y.

\section{Trends in Dissolved Ammonia Concentrations}

The FA trends in NH4 concentrations from 1993 to 2004 showed a widespread spatial tendency toward decreasing concentrations (table 7; fig. 18A). Of the 36 sites with sufficient streamflow and NH4 concentration data for trend analysis, 32 sites had downward trends in concentrations. Of these 32 sites, 24 sites had significant downward trends $(\mathrm{p}<0.10)$. Only four sites had upward FA trends, and only one site, Northrup Creek, N.Y. (0422026250), had a significant upward FA trend in concentrations; however, the magnitude of this upward trend was only $0.002 \mathrm{mg} / \mathrm{L} / \mathrm{yr}$.

When the OA trends in NH4 concentrations from 1993 to 2004 were examined, the results were similar to those of the FA trends. Concentrations at 32 of the 36 sites with sufficient data indicated a tendency toward decreasing concentrations (table 7; fig. 18B), and at 23 of these sites the downward trends were statistically significant $(\mathrm{p}<0.10)$. Of the four sites with upward OA trends in concentrations, the only site with a significant trend was again Northrup Creek, N.Y.

Unlike trends for TN, almost no differences between FA and OA trends in NH4 concentrations were attributed to trends in streamflow. In general, streamflow was not important in determining the significance in the OA trend at most sites; however, the significance level between the FA and OA trends did change at three sites with downward trends in NH4 concentrations.

\section{Trends in Dissolved Ammonia Loads}

From 1993 to 2004, 32 of the 36 sites with sufficient data for analysis showed a tendency toward decreasing NH4 loads (table 7; fig. 18C). These sites with a downward trend were distributed across all three parts of study area. Twenty-six of these sites had significant downward trends in loads $(\mathrm{p}<0.10)$. Most of these sites had significant downward FA trends in both concentration (table 7) and streamflow (table 4). 
A.

Souris River near Sherwood, North Dakota USGS station number 05114000

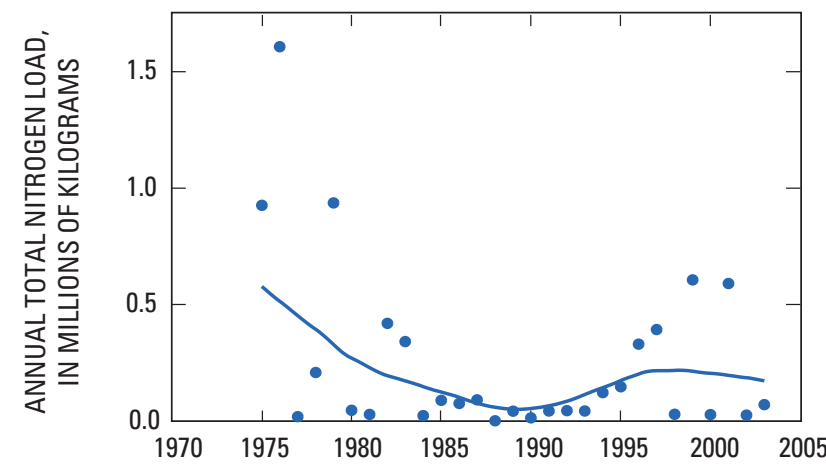

C. lowa River at Wapello, lowa USGS station number 05465500

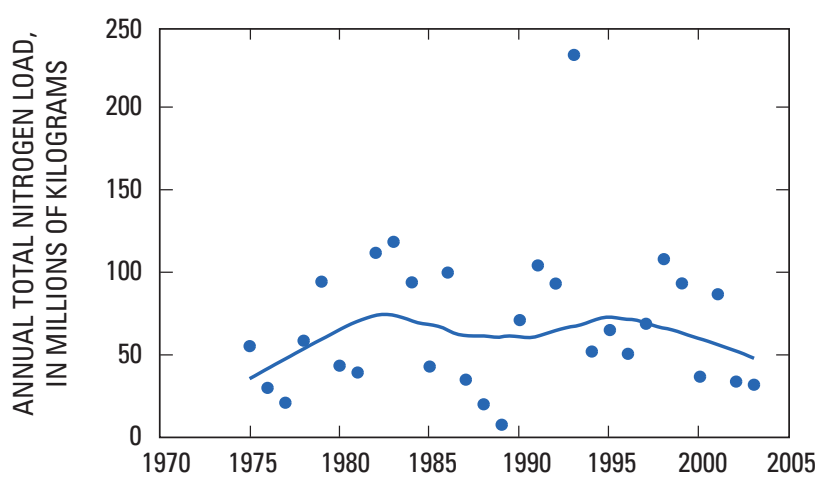

E.

Maumee River at Waterville, Ohio USGS station number 04193500
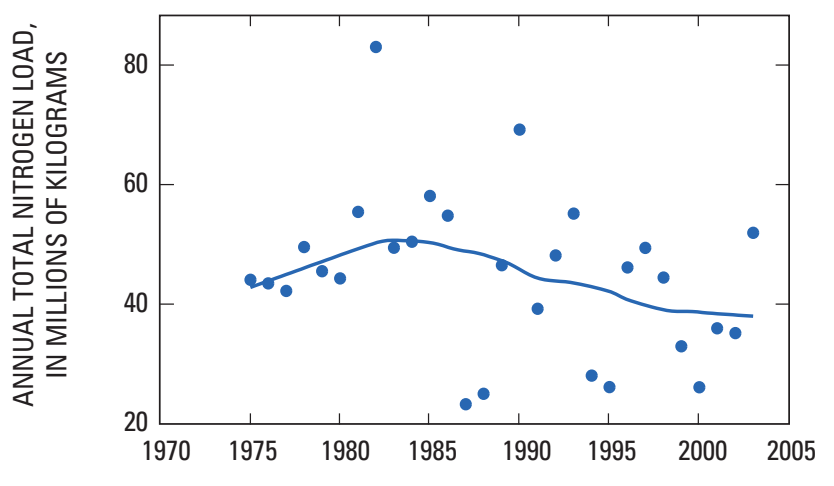

B.

Chippewa River at Durand, Wisconsin USGS station number 05369500

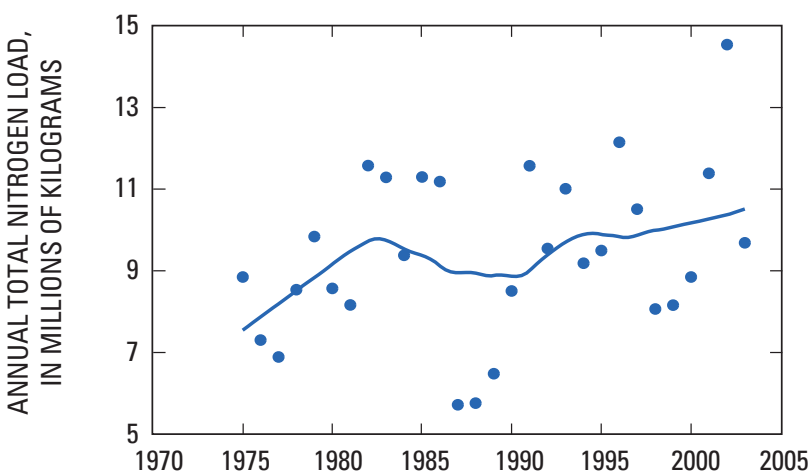

D.

Milwaukee River at Milwaukee, Wisconsin USGS station number 04087000
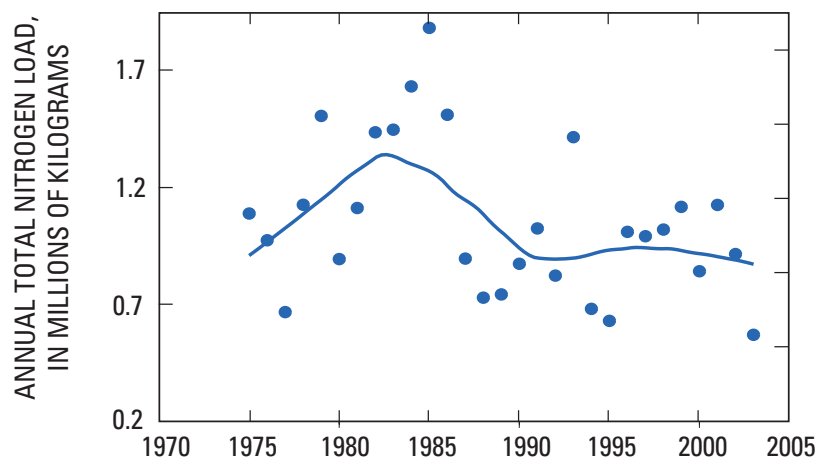

$\boldsymbol{F}$.

Mississippi River at Clinton, lowa USGS station number 05420500

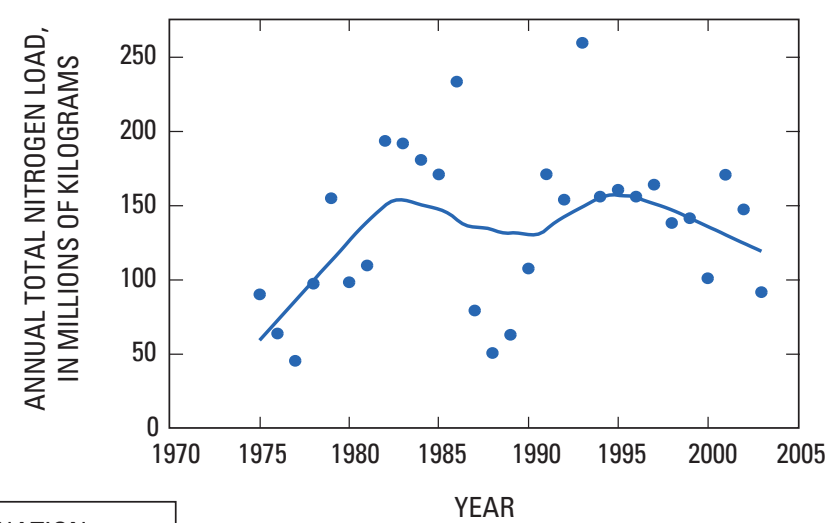

EXPLANATION

LOESS smoothing line

Annual load

Figure 17. Long-term trends in total nitrogen loads from 1975 to 2003 at six selected sites in the study area. 
Table 7. Summary of results for analyses of flow-adjusted trends, overall trends, and trends in loads for dissolved ammonia (NH4, USGS parameter code 00608 ), 1933 to 2004.

[USGS, U.S. Geological Survey; ID, identification; mg/L, milligram per liter; mg/L/yr, milligram per liter per year; \%/yr, percent per year; kg, kilogram; kg/km², kilogram per square kilometer; $\mathrm{NA}$, not available; $\mathrm{NC}$, not calculated; sites in bold indicate long-term evaluation sites]

\begin{tabular}{|c|c|c|c|c|c|c|c|c|c|c|c|c|c|c|c|}
\hline \multirow{3}{*}{$\begin{array}{l}\text { USGS } \\
\text { site } \\
\text { number }\end{array}$} & \multirow{3}{*}{$\begin{array}{c}\text { State-ID } \\
\text { number } \\
\text { (figure 1) }\end{array}$} & \multirow{3}{*}{$\begin{array}{c}\text { Water- } \\
\text { quality } \\
\text { model } \\
\text { (table 3) }\end{array}$} & \multicolumn{7}{|c|}{ Concentration } & \multirow{2}{*}{\multicolumn{6}{|c|}{ Annual loads }} \\
\hline & & & \multicolumn{4}{|c|}{ Flow-adjusted trend } & \multicolumn{3}{|c|}{ Overall trend } & & & & & & \\
\hline & & & $\begin{array}{c}\text { Reference } \\
\text { concentration } \\
\text { (mg/L) }\end{array}$ & $\begin{array}{c}\text { Trend } \\
\text { (mg/L/yr) }\end{array}$ & $\begin{array}{l}\text { Trend } \\
\text { (\%/yr) }\end{array}$ & p-value & $\begin{array}{c}\text { Trend } \\
\text { (mg/L/yr) }\end{array}$ & $\begin{array}{l}\text { Trend } \\
(\% / y r)\end{array}$ & p-value & $\begin{array}{c}\text { Median } \\
\text { annual } \\
\text { load } \\
(\mathrm{kg})\end{array}$ & $\begin{array}{c}\text { Median } \\
\text { yield } \\
\left(\mathbf{k g} / \mathbf{k m}^{2}\right)\end{array}$ & $\begin{array}{c}\text { Reference } \\
\text { load } \\
(\mathbf{k g})\end{array}$ & $\begin{array}{l}\text { Trend } \\
(\mathrm{kg} / \mathrm{yr})\end{array}$ & $\begin{array}{l}\text { Trend } \\
\text { (\%/yr) }\end{array}$ & p-value \\
\hline \multicolumn{16}{|c|}{ Western part } \\
\hline 05056100 & ND-1 & 7 & 0.067 & -0.004 & -5.68 & 0.082 & -0.004 & -5.24 & 0.141 & NA & NA & 662 & -48.0 & -7.23 & 0.103 \\
\hline 05056200 & ND-2 & 7 & .040 & -.002 & -4.48 & .197 & -.002 & -4.84 & .140 & NA & NA & 654 & -52.0 & -7.97 & .072 \\
\hline 05056239 & ND-3 & 7 & .044 & -.003 & -6.75 & .019 & -.003 & -7.07 & .009 & NA & NA & 780 & -66.0 & -8.47 & .018 \\
\hline 05058700 & ND-4 & 7 & .066 & -.003 & -3.92 & .324 & -.003 & -4.47 & .229 & 58,400 & 9.05 & 15,100 & -860 & -5.71 & .179 \\
\hline 05082500 & ND-6 & 7 & .092 & -.008 & -8.20 & .000 & -.008 & -8.29 & .000 & 301,000 & 30.6 & 362,000 & $-31,000$ & -8.47 & .000 \\
\hline 05114000 & ND-7 & 8 & .093 & -.004 & -4.27 & .197 & -.006 & -6.50 & .053 & 11,100 & 1.41 & 587 & 25.8 & 4.40 & .634 \\
\hline 05120000 & ND-8 & 8 & .090 & -.004 & -4.56 & .166 & -.005 & -5.06 & .124 & 16,200 & 1.42 & 3,550 & -100 & -2.87 & .587 \\
\hline \multicolumn{16}{|c|}{ Central part } \\
\hline 04063700 & WI-9 & 9 & 0.038 & -0.002 & -4.66 & 0.000 & -0.001 & -3.68 & 0.003 & 2,660 & 7.38 & 3,160 & -170 & -5.42 & 0.000 \\
\hline 04067500 & WI-10 & 9 & .036 & -.001 & -.43 & .855 & -.001 & -.43 & .856 & 58,700 & 5.76 & 85,100 & -390 & -.46 & .856 \\
\hline 04085427 & WI-12 & 7 & .071 & -.004 & -5.19 & .098 & -.003 & -4.58 & .144 & 16,900 & 12.4 & 9,440 & -560 & -5.89 & .033 \\
\hline 04087000 & WI-13 & 8 & .037 & -.001 & -3.17 & .051 & -.001 & -3.17 & .046 & 30,000 & 16.6 & 11,900 & -490 & -4.08 & .040 \\
\hline 05287890 & $\mathrm{MN}-14$ & 8 & .183 & -.012 & -6.32 & .000 & -.012 & -6.30 & .000 & 4,350 & 19.5 & 3,980 & -320 & -7.96 & .000 \\
\hline 05340500 & WI-15 & 7 & .028 & .001 & .29 & .931 & .001 & .20 & .952 & 188,000 & 11.6 & 107,000 & -990 & -.93 & .781 \\
\hline 05369500 & WI-16 & 9 & .052 & .001 & -.64 & .746 & -.001 & -1.19 & .543 & 507,000 & 21.7 & 338,000 & $-7,700$ & -2.27 & .336 \\
\hline 05382000 & WI-17 & 9 & .063 & -.001 & -.23 & .932 & -.002 & -2.59 & .278 & 132,000 & 24.6 & 91,500 & $-4,600$ & -5.00 & .036 \\
\hline 05407000 & WI-20 & 7 & .046 & -.001 & -2.79 & .366 & -.002 & -3.46 & .207 & 498,000 & 18.5 & 384,000 & $-19,000$ & -4.84 & .058 \\
\hline 05420500 & IA-21 & 3 & .106 & -.008 & -7.66 & .000 & -.008 & -7.52 & .000 & $4,120,000$ & 18.6 & $6,250,000$ & $-500,000$ & -7.94 & .000 \\
\hline 054310157 & WI-24 & 9 & .215 & -.066 & -30.70 & .000 & -.066 & -30.7 & .000 & NA & NA & 236 & $\mathrm{NC}$ & -3.66 & .000 \\
\hline 05465500 & IA-25 & 9 & .024 & -.002 & -7.35 & .003 & -.002 & -7.59 & .000 & 859,000 & 26.5 & 221,000 & $-18,000$ & -8.26 & .000 \\
\hline 05474000 & IA-26 & 7 & .067 & -.005 & -6.71 & .021 & -.005 & -7.38 & .003 & 254,000 & 22.8 & 138,000 & $-11,000$ & -8.28 & .000 \\
\hline 05500000 & MO-28 & 8 & .069 & -.004 & -5.90 & .000 & -.005 & -6.89 & .000 & 40,100 & 24.9 & 9,130 & -740 & -8.13 & .000 \\
\hline 05525500 & IL-30 & 9 & .033 & -.002 & -6.94 & .000 & -.002 & -7.09 & .000 & 42,000 & 36.3 & 4,800 & -370 & -7.62 & .007 \\
\hline
\end{tabular}


Table 7. Summary of results for analyses of flow-adjusted trends, overall trends, and trends in loads for dissolved ammonia (NH4, USGS parameter code 00608), 1933 to 2004.-Continued

[USGS, U.S. Geological Survey; ID, identification; mg/L, milligram per liter; mg/L/yr, milligram per liter per year; \%/yr, percent per year; kg, kilogram; kg/km², kilogram per square kilometer; $\mathrm{NA}$, not available; NC, not calculated; sites in bold indicate long-term evaluation sites]

\begin{tabular}{|c|c|c|c|c|c|c|c|c|c|c|c|c|c|c|c|}
\hline \multirow{3}{*}{$\begin{array}{l}\text { USGS } \\
\text { site } \\
\text { number }\end{array}$} & \multirow{3}{*}{$\begin{array}{c}\text { State-ID } \\
\text { number } \\
\text { (figure 1) }\end{array}$} & \multirow{3}{*}{$\begin{array}{c}\text { Water- } \\
\text { quality } \\
\text { model } \\
\text { (table 3) }\end{array}$} & \multicolumn{7}{|c|}{ Concentration } & \multirow{2}{*}{\multicolumn{6}{|c|}{ Annual loads }} \\
\hline & & & \multicolumn{4}{|c|}{ Flow-adjusted trend } & \multicolumn{3}{|c|}{ Overall trend } & & & & & & \\
\hline & & & $\begin{array}{c}\text { Reference } \\
\text { concentration } \\
\text { (mg/L) }\end{array}$ & $\begin{array}{c}\text { Trend } \\
\text { (mg/L/yr) }\end{array}$ & $\begin{array}{l}\text { Trend } \\
(\% / y r)\end{array}$ & p-value & $\begin{array}{c}\text { Trend } \\
\text { (mg/L/yr) }\end{array}$ & $\begin{array}{l}\text { Trend } \\
(\% / y r)\end{array}$ & p-value & $\begin{array}{c}\text { Median } \\
\text { annual } \\
\text { load } \\
(\mathbf{k g})\end{array}$ & $\begin{array}{l}\text { Median } \\
\text { yield } \\
\left(\mathbf{k g} / \mathbf{k m}^{2}\right)\end{array}$ & $\begin{array}{c}\text { Reference } \\
\text { load } \\
(\mathrm{kg})\end{array}$ & $\begin{array}{l}\text { Trend } \\
(\mathbf{k g} / \mathrm{yr})\end{array}$ & $\begin{array}{l}\text { Trend } \\
\text { (\%/yr) }\end{array}$ & p-value \\
\hline \multicolumn{16}{|c|}{ Central part-continued } \\
\hline 05531500 & IL-31 & 7 & 0.192 & -0.011 & -5.76 & 0.000 & -0.011 & -5.75 & 0.000 & 35,000 & 118 & 23,400 & $-1,400$ & -5.91 & 0.000 \\
\hline 05532500 & IL-32 & 8 & .167 & -.012 & -6.91 & .000 & -.012 & -6.93 & .000 & 157,000 & 96.3 & 86,400 & $-6,200$ & -7.24 & .000 \\
\hline 05540275 & IL-33 & 3 & .080 & -.004 & -5.24 & .000 & -.004 & -5.41 & .000 & 772 & 30.1 & 461 & -31 & -6.68 & .000 \\
\hline 05586100 & IL-37 & 7 & .112 & -.008 & -6.76 & .000 & -.007 & -6.48 & .000 & $2,020,000$ & 29.1 & $2,780,000$ & $-210,000$ & -7.68 & .000 \\
\hline 07014500 & MO-38 & 9 & .018 & -.001 & -7.63 & .003 & -.001 & -7.83 & .001 & 24,300 & 6.36 & 20,700 & $-1,700$ & -8.28 & .000 \\
\hline 07018100 & MO-39 & 9 & .016 & -.001 & -5.49 & .018 & -.001 & -5.81 & .006 & 20,600 & 10.8 & 7,290 & -530 & -7.31 & .000 \\
\hline \multicolumn{16}{|c|}{ Eastern part } \\
\hline 03085000 & PA-40 & 7 & 0.103 & -0.004 & -3.44 & 0.054 & -0.004 & -3.67 & 0.036 & 332,000 & 17.5 & 688,000 & $-15,000$ & -2.24 & 0.349 \\
\hline 03353637 & $\mathrm{IN}-42$ & 9 & .028 & -.002 & -7.44 & .000 & -.002 & -7.49 & .000 & 769 & 17.5 & 247 & -19.0 & -7.85 & .000 \\
\hline 04186500 & $\mathrm{OH}-43$ & 7 & .058 & -.005 & -8.53 & .000 & -.005 & -8.55 & .000 & 35,400 & 41.1 & 4,160 & -360 & -8.58 & .004 \\
\hline 04193500 & OH-44 & 7 & .056 & -.004 & -6.69 & .001 & -.004 & -6.63 & .002 & 618,000 & 37.7 & 106,000 & $-6,900$ & -6.50 & .031 \\
\hline 0422026250 & NY-45 & 7 & .032 & .002 & 7.75 & .000 & .002 & 7.48 & .000 & 1,810 & 69.3 & 202 & $\mathrm{NC}$ & 18.46 & .000 \\
\hline 04232034 & NY-46 & 7 & .003 & .001 & 1.82 & .687 & .001 & 1.48 & .738 & 249 & 2.45 & 83 & .34 & .40 & .929 \\
\hline 0423204920 & NY-47 & 8 & .019 & .001 & 2.52 & .167 & .001 & 2.87 & .128 & 285 & 15.8 & 89 & .27 & .30 & .902 \\
\hline 0423205025 & NY-48 & 9 & .022 & -.001 & -5.95 & .000 & -.001 & -5.94 & .000 & 4,260 & 11.5 & 2,110 & -14 & -6.77 & .000 \\
\hline
\end{tabular}




\section{A. Flow-adjusted trend in concentrations}

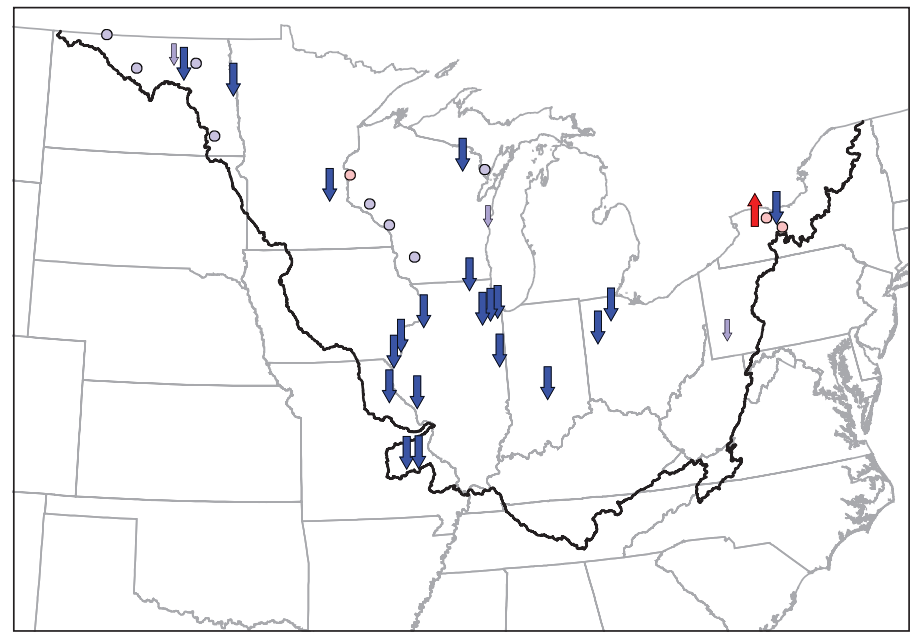

\section{B. Overall trend in concentrations}

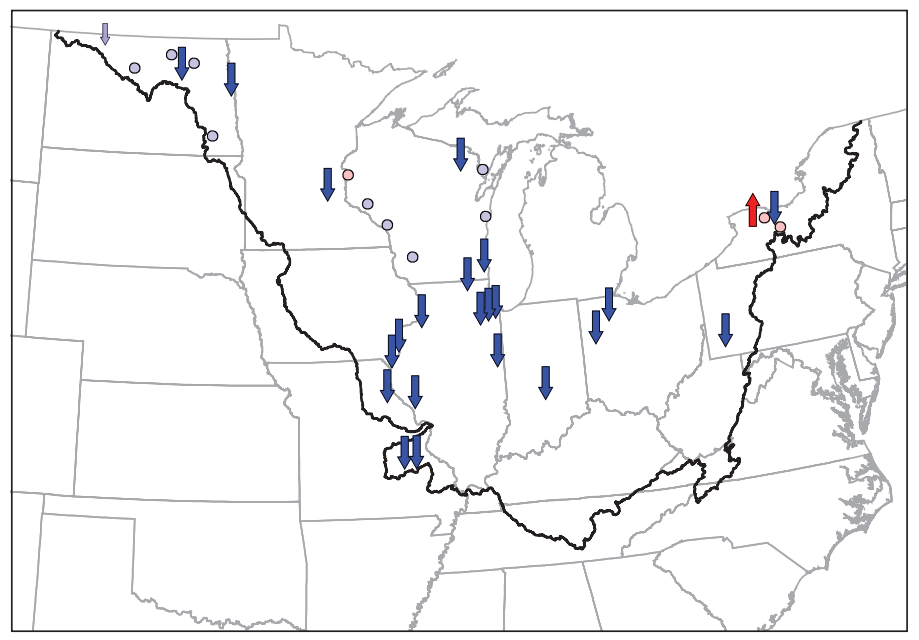

DISSOLVED AMMONIA

\begin{tabular}{|l|}
\hline \multicolumn{1}{|c|}{ EXPLANATION } \\
Trends \\
U Upward $(\mathrm{p}<0.05)$ \\
$\Uparrow$ Upward $(0.05 \leq \mathrm{p}<0.1)$ \\
$\circ$ Upward $(\mathrm{p} \geq 0.1)$ \\
$\circ$ Downward $(\mathrm{p} \geq 0.1)$ \\
$\rrbracket$ Downward $(0.05 \leq \mathrm{p}<0.1)$ \\
$\downarrow$ Downward $(\mathrm{p}<0.05)$
\end{tabular}

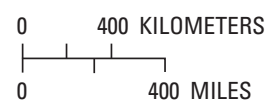

\section{Trend in annual loads}

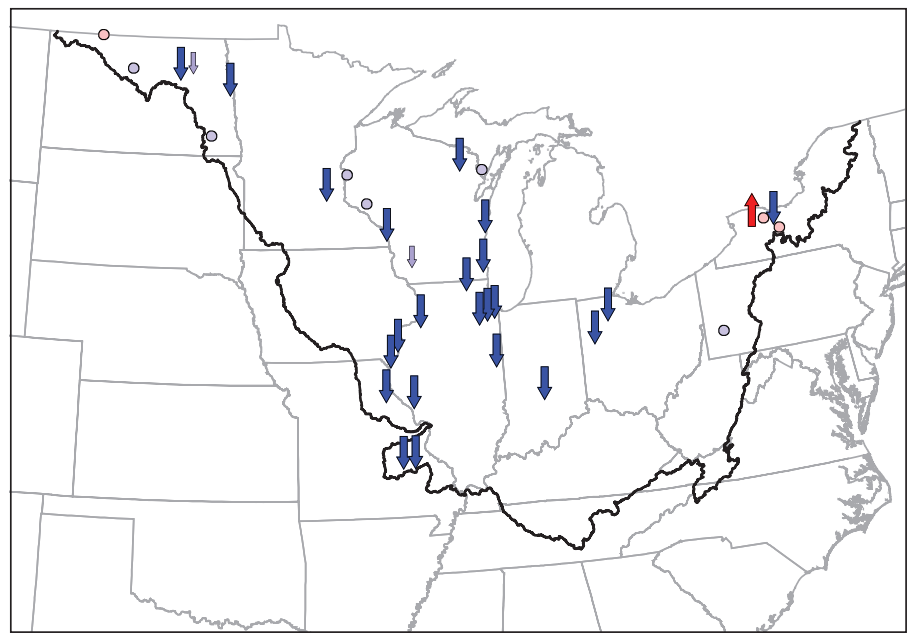

Figure 18. Trends in dissolved ammonia from 1993 to 2004 for $\boldsymbol{A}$, flow-adjusted concentrations, $\boldsymbol{B}$, overall concentrations, and $\boldsymbol{C}$, annual loads throughout the study area. 


\section{Total Kjeldahl Nitrogen}

\section{General Patterns in Total Kjeldahl Nitrogen Concentrations and Yields}

Median midmonthly Kjeldahl nitrogen (KJN) concentrations at 36 of 49 trend sites that had sufficient data for analysis, based on data from 1993 to 2004, ranged from 0.200 to $1.50 \mathrm{mg} / \mathrm{L}$. The mean and median values of the median $\mathrm{KJN}$ concentrations at these sites were $0.88 \mathrm{mg} / \mathrm{L}$. Concentrations were uniformly high throughout the western parts of the study area and sporadically high at isolated sites throughout the rest of the study area. The lowest concentrations were at sites in eastern Ohio and eastern Pennsylvania. The highest concentrations were in areas with intensive agriculture, and the lowest concentrations were in forested areas.

Median annual KJN yields at the trend sites ranged from 9.13 to $796 \mathrm{~kg} / \mathrm{km}^{2}$ (table 8), based on data from 1993 to 2004. The mean and median values from the median yields at these sites were 313 and $261 \mathrm{~kg} / \mathrm{km}^{2}$, respectively. The highest yields were from two sites in Illinois and one site in Missouri. The lowest yields were throughout the northwestern part of the study area, including three sites in North Dakota and three sites in northern Wisconsin.

\section{Trends in Total Kjeldahl Nitrogen Concentrations}

The FA trends in KJN concentrations from 1993 to 2004 showed no distinct spatial pattern. Of the 36 sites that had sufficient streamflow and KJN concentration data for trend analysis (table 8; fig. 19A), 17 sites had tendency toward decreasing concentrations, and 19 sites had a tendency toward increasing concentrations. Seven sites had significant downward trends, and six sites had significant upward trends $(\mathrm{p}<0.10)$.

Of the 36 sites that had sufficient streamflow and KJN concentration data from 1993 to 2004 for analysis (table 8; fig. 19B), 18 sites had downward OA trends in concentrations, and 18 sites had upward trends. Of these, nine sites had significant downward trends, and six sites had significant upward trends $(\mathrm{p}<0.10)$. When the OA trends in KJN concentrations were examined no distinct spatial patterns were evident; however, the tendencies and statistical results were slightly different than those of the FA trends. The differences in the results of the FA and OA trend analyses were attributable to differences in the trends in streamflow (fig. 12).

\section{Trends in Total Kjeldahl Nitrogen Loads}

From 1993 to 2004, KJN loads at the 36 trend sites that had sufficient data for analysis showed a tendency toward decreasing loads at 30 sites and a tendency toward increasing loads at 6 sites (table 8; fig. 19C). The sites with downward trends in KJN loads were distributed across all three parts of study area, and three of the six sites with upward trends were in the eastern part of the study area. Thirteen of the sites with downward trends in loads had significant trends, whereas only one of the six sites with upward trends in loads had a significant trend $(\mathrm{p}<0.10)$.

\section{Dissolved Nitrite plus Nitrate Nitrogen}

\section{General Patterns in Dissolved Nitrite plus Nitrate Nitrogen Concentrations and Yields}

Median midmonthly dissolved nitrite plus nitrate nitrogen (NO2NO3) concentrations at 29 of the 49 trend sites ranged from 0.05 to $8.11 \mathrm{mg} / \mathrm{L}$, based on data from 1993 to 2004 . The mean and median values from the median NO2NO3 concentrations at these sites were 2.21 and $0.65 \mathrm{mg} / \mathrm{L}$, respectively. The highest concentrations were in the central and eastern parts of the study area, and the lowest concentrations were in the north-central and western parts of the study area. The highest concentrations were in areas with intensive agriculture, and the lowest concentrations were in forested areas.

Median annual NO2NO3 yields at the trend sites ranged from 1.80 to $4,190 \mathrm{~kg} / \mathrm{km}^{2}$, based on data from 1993 to 2004 (table 9). The mean and median values of the median yields at these trend sites were 774 and $364 \mathrm{~kg} / \mathrm{km}^{2}$, respectively. The highest yields were at two sites in Ohio and one site each in Illinois and Iowa. The lowest yields were from six sites from throughout the northwest and north-central parts of the study area, three sites in North Dakota and three sites in northern Wisconsin.

\section{Trends in Dissolved Nitrite plus Nitrate Nitrogen Concentrations}

The FA trends in NO2NO3 concentrations from 1993 to 2004 showed no distinct spatial pattern (fig. 20A). Of the 29 sites that had sufficient streamflow and NO2NO3 concentration data for analysis (table 9 and fig. 20A), 12 sites had downward trends, and 17 sites had upward trends. Of these sites, three sites (one in North Dakota, one in Illinois, and one in Indiana) had significant downward trends, and four sites (one in Iowa, one in Illinois, and two in Wisconsin) had significant upward trends $(\mathrm{p}<0.10)$.

When the OA trends in $\mathrm{NO} 2 \mathrm{NO} 3$ concentrations from 1993 to 2004 were examined, no distinct spatial patterns were evident; however, tendencies and trend results were somewhat different than those of the FA trends. These differences in the results of the FA and OA trend analyses are attributed to differences in streamflow trends (fig. 12). Of the 29 sites that had sufficient streamflow and NO2NO3 concentration data for analysis (table 9; fig. 20B), 13 sites had downward OA trends, and 16 sites had upward OA trends. Of these sites, four sites had significant downward trends, and three sites had significant upward trends $(\mathrm{p}<0.10)$. 


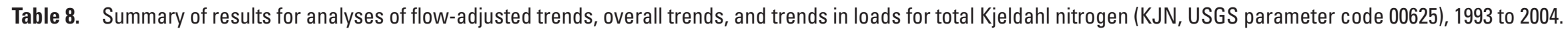

[USGS, U.S. Geological Survey; ID, identification; mg/L, milligram per liter; mg/L/yr, milligram per liter per year; \%/yr, percent per year; kg, kilogram; kg/km², kilogram per square kilometer; kg/yr, kilogram per year; NA, not available; NC, not calculated; sites in bold indicate long-term evaluation sites]

\begin{tabular}{|c|c|c|c|c|c|c|c|c|c|c|c|c|c|c|c|}
\hline \multirow{3}{*}{$\begin{array}{c}\text { USGS } \\
\text { site } \\
\text { number }\end{array}$} & \multirow{3}{*}{$\begin{array}{c}\text { State-ID } \\
\text { number } \\
\text { (figure 1) }\end{array}$} & \multirow{3}{*}{$\begin{array}{c}\text { Water- } \\
\text { quality } \\
\text { model } \\
\text { (table 3) }\end{array}$} & \multicolumn{7}{|c|}{ Concentration } & \multirow{2}{*}{\multicolumn{6}{|c|}{ Annual loads }} \\
\hline & & & \multicolumn{4}{|c|}{ Flow-adjusted trend } & \multicolumn{3}{|c|}{ Overall trend } & & & & & & \\
\hline & & & $\begin{array}{c}\text { Reference } \\
\text { concentration } \\
\text { (mg/L) }\end{array}$ & $\begin{array}{c}\text { Trend } \\
\text { (mg/L/yr) }\end{array}$ & $\begin{array}{l}\text { Trend } \\
(\% / y r)\end{array}$ & p-value & $\begin{array}{c}\text { Trend } \\
\text { (mg/L/yr) }\end{array}$ & $\begin{array}{l}\text { Trend } \\
\text { (\%/yr) }\end{array}$ & p-value & $\begin{array}{c}\text { Median } \\
\text { annual } \\
\text { load } \\
(\mathrm{kg})\end{array}$ & $\begin{array}{c}\text { Median } \\
\text { yield } \\
\left(\mathbf{k g} / \mathbf{k m}^{2}\right)\end{array}$ & $\begin{array}{c}\text { Reference } \\
\text { load } \\
(\mathbf{k g})\end{array}$ & $\begin{array}{c}\text { Trend } \\
(\mathrm{kg} / \mathrm{yr})\end{array}$ & $\begin{array}{l}\text { Trend } \\
(\% / y r)\end{array}$ & p-value \\
\hline \multicolumn{16}{|c|}{ Western part } \\
\hline 05056100 & ND-1 & 9 & 1.266 & 0.017 & 1.37 & 0.525 & 0.036 & 2.84 & 0.328 & NA & NA & 12,400 & -450 & -3.66 & 0.552 \\
\hline 05056200 & ND-2 & 7 & 1.497 & .039 & 2.61 & .031 & .066 & 4.44 & .009 & NA & NA & 25,400 & $-1,500$ & -5.96 & .266 \\
\hline 05056239 & ND-3 & 9 & 1.126 & -.009 & -.79 & .767 & .005 & .44 & .881 & NA & NA & 20,900 & $-1,300$ & -6.45 & .163 \\
\hline 05058700 & ND-4 & 3 & 1.017 & -.002 & -.19 & .936 & -.006 & -.60 & .795 & 511,000 & 79.3 & 233,000 & $-6,800$ & -2.93 & .433 \\
\hline 05064500 & $\mathrm{MN}-5$ & 3 & 1.170 & -.058 & -4.97 & .004 & -.060 & -5.09 & .001 & $3,400,000$ & 345 & $2,330,000$ & $-140,000$ & -5.82 & .006 \\
\hline 05082500 & ND-6 & 3 & 1.029 & -.033 & -3.24 & .011 & -.036 & -3.49 & .003 & $5,470,000$ & 555 & $4,050,000$ & $-210,000$ & -5.10 & .011 \\
\hline 05114000 & ND-7 & 9 & 1.955 & -.024 & -1.25 & .276 & -.034 & -1.72 & .185 & 92,300 & 11.7 & 10,800 & NC & 32.9 & .122 \\
\hline 05120000 & ND-8 & 5 & 1.092 & .017 & 1.55 & .244 & .016 & 1.46 & .266 & 104,000 & 9.13 & 41,700 & 3,190 & 7.65 & .367 \\
\hline \multicolumn{16}{|c|}{ Central part } \\
\hline 04063700 & WI-9 & 9 & 0.411 & 0.004 & 1.04 & 0.228 & -0.002 & -0.47 & 0.619 & 55,200 & 153 & 34,200 & $-1,100$ & -3.32 & 0.035 \\
\hline 04067500 & WI-10 & 9 & .323 & -.003 & -.87 & .510 & -.003 & -.88 & .516 & $1,060,000$ & 104 & 769,000 & $-7,000$ & -.90 & .636 \\
\hline 04085427 & WI-12 & 3 & 1.421 & .020 & 1.40 & .460 & .016 & 1.14 & .530 & 337,000 & 248 & 187,000 & $-3,700$ & -1.96 & .530 \\
\hline 04087000 & WI-13 & 8 & .821 & .004 & .52 & .424 & .005 & .62 & .340 & 406,000 & 225 & 267,000 & $-2,500$ & -.92 & .591 \\
\hline 05287890 & $\mathrm{MN}-14$ & 9 & 1.071 & .023 & 2.17 & .001 & .003 & .33 & .728 & 104,000 & 467 & 24,400 & $-1,300$ & -5.38 & .075 \\
\hline 05340500 & WI-15 & 9 & .387 & .009 & 2.25 & .293 & .006 & 1.51 & .481 & $2,410,000$ & 149 & $1,410,000$ & 3,510 & .25 & .923 \\
\hline 05369500 & WI-16 & 9 & .544 & .006 & 1.03 & .222 & .005 & .96 & .244 & $5,130,000$ & 220 & $3,540,000$ & $-15,000$ & -.43 & .775 \\
\hline 05382000 & WI-17 & 8 & .657 & .010 & 1.54 & .241 & -.001 & -.09 & .940 & $1,400,000$ & 261 & 952,000 & $-33,000$ & -3.50 & .046 \\
\hline 05407000 & WI-20 & 7 & .673 & .020 & 2.99 & .046 & .016 & 2.43 & .064 & $6,610,000$ & 245 & $5,610,000$ & $-27,000$ & -.48 & .756 \\
\hline 05420500 & IA-21 & 9 & 1.625 & -.030 & -1.83 & .075 & -.035 & -2.17 & .025 & $53,500,000$ & 241 & $95,700,000$ & $-4,400,000$ & -4.60 & .000 \\
\hline 05465500 & IA-25 & 7 & 1.076 & .024 & 2.19 & .278 & .041 & 3.82 & .066 & $11,800,000$ & 366 & $9,860,000$ & $-320,000$ & -3.29 & .141 \\
\hline 05500000 & MO-28 & 8 & .859 & -.001 & -.04 & .965 & -.015 & -1.75 & .099 & 900,000 & 560 & 115,000 & $-7,800$ & -6.81 & .021 \\
\hline 05514500 & MO-29 & 7 & .942 & -.039 & -4.17 & .011 & -.040 & -4.25 & .019 & $1,000,000$ & 427 & 106,000 & $-4,900$ & -4.59 & .412 \\
\hline 05525500 & IL-30 & 8 & .538 & -.002 & -.42 & .929 & -.005 & -1.00 & .833 & 527,000 & 456 & 62,800 & $-2,600$ & -4.13 & .524 \\
\hline 05531500 & IL-31 & 9 & 1.458 & -.030 & -2.08 & .036 & -.030 & -2.05 & .038 & 237,000 & 796 & 178,000 & $-4,300$ & -2.43 & .074 \\
\hline 05532500 & IL-32 & 9 & 1.586 & -.036 & -2.29 & .049 & -.035 & -2.21 & .058 & 946,000 & 580 & 814,000 & $-28,000$ & -3.42 & .030 \\
\hline
\end{tabular}


Table 8. Summary of results for analyses of flow-adjusted trends, overall trends, and trends in loads for total Kjeldahl nitrogen (KJN, USGS parameter code 00625), 1993 to 2004.-Continued

[USGS, U.S. Geological Survey; ID, identification; mg/L, milligram per liter; mg/L/yr, milligram per liter per year; \%/yr, percent per year; $\mathrm{kg}$, kilogram; $\mathrm{kg} / \mathrm{km}^{2}$, kilogram per square kilometer; $\mathrm{kg} / \mathrm{yr}$, kilogram per year; NA, not available; $\mathrm{NC}$, not calculated; sites in bold indicate long-term evaluation sites]

\begin{tabular}{|c|c|c|c|c|c|c|c|c|c|c|c|c|c|c|c|}
\hline \multirow{3}{*}{$\begin{array}{c}\text { USGS } \\
\text { site } \\
\text { number }\end{array}$} & \multirow{3}{*}{$\begin{array}{c}\text { State-ID } \\
\text { number } \\
\text { (figure 1) }\end{array}$} & \multirow{3}{*}{$\begin{array}{c}\text { Water- } \\
\text { quality } \\
\text { model } \\
\text { (table 3) }\end{array}$} & \multicolumn{7}{|c|}{ Concentration } & \multirow{2}{*}{\multicolumn{6}{|c|}{ Annual loads }} \\
\hline & & & \multicolumn{4}{|c|}{ Flow-adjusted trend } & \multicolumn{3}{|c|}{ Overall trend } & & & & & & \\
\hline & & & $\begin{array}{c}\text { Reference } \\
\text { concentration } \\
\text { (mg/L) }\end{array}$ & $\begin{array}{c}\text { Trend } \\
\text { (mg/L/yr) }\end{array}$ & $\begin{array}{l}\text { Trend } \\
(\% / y r)\end{array}$ & p-value & $\begin{array}{c}\text { Trend } \\
\text { (mg/L/yr) }\end{array}$ & $\begin{array}{l}\text { Trend } \\
(\% / y r)\end{array}$ & $p$-value & $\begin{array}{l}\text { Median } \\
\text { annual } \\
\text { load } \\
(\mathrm{kg})\end{array}$ & $\begin{array}{c}\text { Median } \\
\text { yield } \\
\left(\mathbf{k g} / \mathbf{k m}^{2}\right)\end{array}$ & $\begin{array}{c}\text { Reference } \\
\text { load } \\
(\mathrm{kg})\end{array}$ & $\begin{array}{c}\text { Trend } \\
(\mathrm{kg} / \mathrm{yr})\end{array}$ & $\begin{array}{l}\text { Trend } \\
(\% / y r)\end{array}$ & p-value \\
\hline \multicolumn{16}{|c|}{ Central part-continued } \\
\hline 05540275 & IL-33 & 3 & 0.589 & 0.011 & 1.81 & 0.155 & 0.007 & 1.24 & 0.322 & 7,980 & 311 & 3,400 & -92.0 & -2.71 & 0.329 \\
\hline 05586100 & IL-37 & 8 & 1.150 & .013 & 1.13 & .345 & .012 & 1.06 & .346 & $25,300,000$ & 365 & $28,000,000$ & $-1,200,000$ & -4.41 & .010 \\
\hline 07014500 & MO-38 & 8 & .172 & -.002 & -1.14 & .695 & -.005 & -2.72 & .251 & 599,000 & 157 & 193,000 & $-12,000$ & -6.11 & .004 \\
\hline 07018100 & MO-39 & 8 & .203 & -.001 & -.67 & .833 & -.004 & -1.78 & .562 & 485,000 & 255 & 95,100 & $-5,200$ & -5.47 & .043 \\
\hline \multicolumn{16}{|c|}{ Eastern part } \\
\hline 03085000 & PA-40 & 8 & 0.228 & 0.004 & 1.96 & 0.690 & 0.004 & 1.83 & 0.709 & $3,810,000$ & 200 & $1,510,000$ & 68,500 & 4.52 & 0.435 \\
\hline 03353637 & IN-42 & 9 & .223 & .011 & 4.92 & .003 & .008 & 3.67 & .057 & 14,100 & 319 & 1,840 & -5.30 & -.29 & .952 \\
\hline 04186500 & $\mathrm{OH}-43$ & 8 & .773 & -.007 & -.90 & .602 & -.007 & -.94 & .597 & 355,000 & 413 & 59,400 & -750 & -1.25 & .777 \\
\hline 04193500 & OH-44 & 8 & 1.065 & .022 & 2.03 & .093 & .022 & 2.09 & .090 & $8,560,000$ & 522 & $1,950,000$ & 54,200 & 2.78 & .457 \\
\hline 0422026250 & NY-45 & 9 & 1.111 & .027 & 2.46 & .001 & .029 & 2.60 & .000 & 12,700 & 484 & 6,990 & $\mathrm{NC}$ & 10.24 & .002 \\
\hline 04232034 & NY-46 & 9 & .621 & .009 & 1.50 & .260 & .005 & .87 & .568 & 22,200 & 218 & 16,300 & -23.0 & -.14 & .953 \\
\hline 0423204920 & NY-47 & 9 & .781 & -.010 & -1.27 & .129 & -.011 & -1.45 & .090 & 6,590 & 365 & 3,690 & -120 & -3.16 & .115 \\
\hline 0423205025 & NY-48 & 9 & .831 & -.018 & -2.19 & .000 & -.020 & -2.40 & .000 & 84,200 & 227 & 80,600 & $-3,200$ & -3.96 & .007 \\
\hline
\end{tabular}




\section{A. Flow-adjusted trend in concentrations}

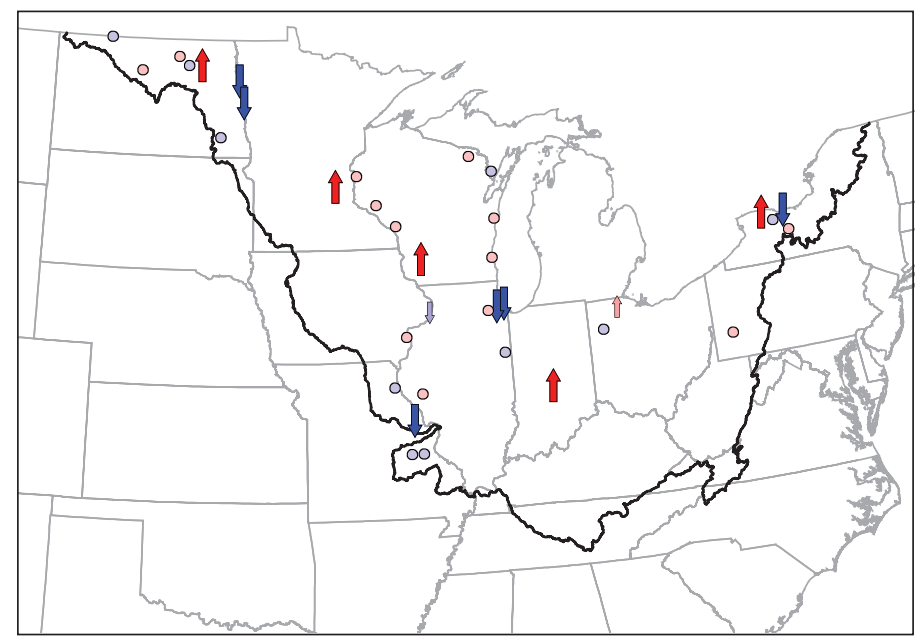

\section{KJELDAHL NITROGEN}

EXPLANATION
Trends
Upward $(\mathrm{p}<0.05)$

B. Overall trend in concentrations

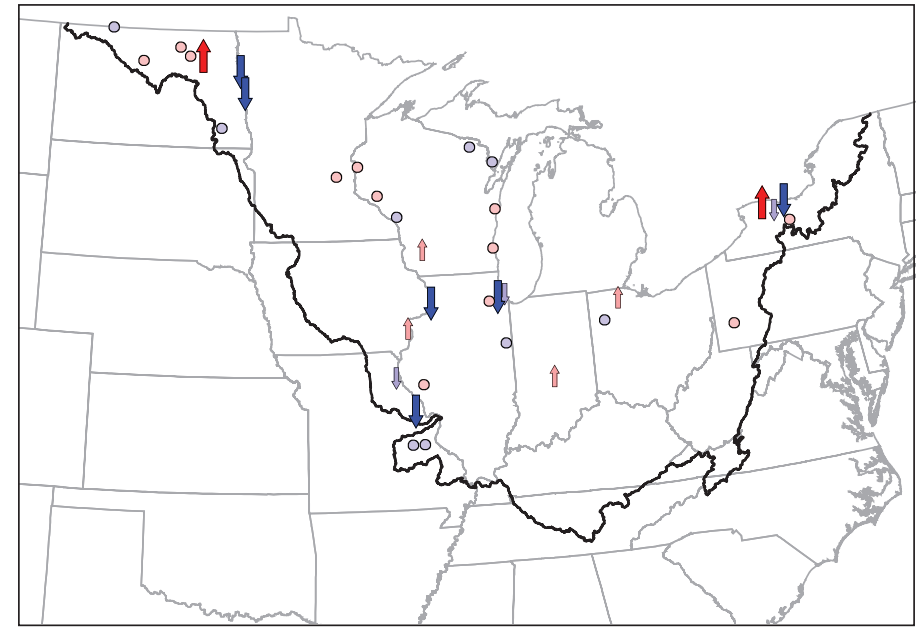

î Upward $(0.05 \leq \mathrm{p}<0.1)$

○ Upward $(\mathrm{p} \geq 0.1)$

- Downward $(\mathrm{p} \geq 0.1)$

$\Downarrow$ Downward $(0.05 \leq \mathrm{p}<0.1)$

$\checkmark$ Downward $(\mathrm{p}<0.05)$

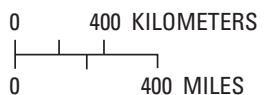

\section{Trend in annual loads}

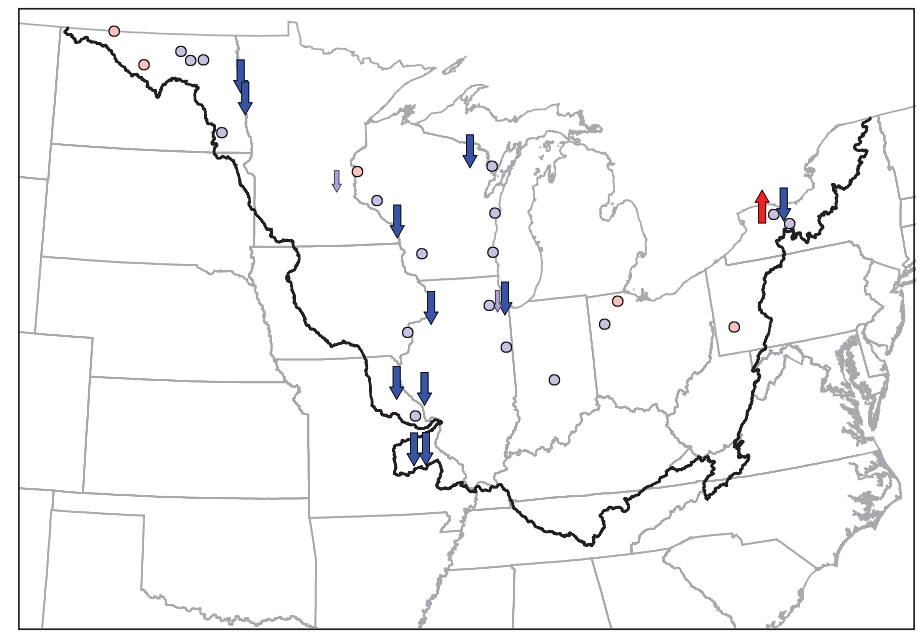

Figure 19. Trends in total Kjeldahl nitrogen from 1993 to 2004 for $\boldsymbol{A}$, flow-adjusted concentrations, $\boldsymbol{B}$, overall concentrations, and $\boldsymbol{C}$, annual loads throughout the study area. 
Table 9. Summary of results for analyses of flow-adjusted trends, overall trends, and trends in loads for dissolved nitrite plus nitrate nitrogen (NO3, USGS parameter code 00631), 1993 to 2004 .-

[USGS, U.S. Geological Survey; ID, identification; mg/L, milligram per liter; mg/L/yr, milligram per liter per year; \%/yr, percent per year; $\mathrm{kg}$, kilogram; $\mathrm{kg} / \mathrm{km}{ }^{2}$, kilogram per square kilometer; $\mathrm{kg} / \mathrm{yr}$, kilogram per year; NA, not available; NC, not calculated; sites in bold indicate long-term evaluation sites]

\begin{tabular}{|c|c|c|c|c|c|c|c|c|c|c|c|c|c|c|c|}
\hline \multirow{3}{*}{$\begin{array}{l}\text { USGS } \\
\text { site } \\
\text { number }\end{array}$} & \multirow{3}{*}{$\begin{array}{c}\text { State-ID } \\
\text { number } \\
\text { (figure 1) }\end{array}$} & \multirow{3}{*}{$\begin{array}{c}\text { Water- } \\
\text { quality } \\
\text { model } \\
\text { (table 3) }\end{array}$} & \multicolumn{7}{|c|}{ Concentration } & \multirow{2}{*}{\multicolumn{6}{|c|}{ Annual loads }} \\
\hline & & & \multicolumn{4}{|c|}{ Flow-adjusted trend } & \multicolumn{3}{|c|}{ Overall trend } & & & & & & \\
\hline & & & $\begin{array}{c}\text { Reference } \\
\text { concentration } \\
\text { (mg/L) }\end{array}$ & $\begin{array}{c}\text { Trend } \\
\text { (mg/L/yr) }\end{array}$ & $\begin{array}{l}\text { Trend } \\
\text { (\%/yr) }\end{array}$ & p-value & $\begin{array}{c}\text { Trend } \\
\text { (mg/L/yr) }\end{array}$ & $\begin{array}{l}\text { Trend } \\
(\% / y r)\end{array}$ & p-value & $\begin{array}{c}\text { Median } \\
\text { annual } \\
\text { load } \\
(\mathbf{k g})\end{array}$ & $\begin{array}{c}\text { Median } \\
\text { yield } \\
\left(\mathrm{kg} / \mathrm{km}^{2}\right)\end{array}$ & $\begin{array}{c}\text { Reference } \\
\text { load } \\
(\mathrm{kg})\end{array}$ & $\begin{array}{c}\text { Trend } \\
(\mathrm{kg} / \mathrm{yr})\end{array}$ & $\begin{array}{l}\text { Trend } \\
(\% / y r)\end{array}$ & p-value \\
\hline \multicolumn{16}{|c|}{ Western part } \\
\hline 05056100 & ND-1 & 8 & 0.018 & 0.003 & 15.00 & 0.272 & 0.003 & 16.76 & 0.251 & NA & NA & 173 & 4.3 & 2.47 & 0.852 \\
\hline 05056200 & ND-2 & 8 & .036 & -.001 & -4.00 & .553 & -.002 & -5.39 & .354 & NA & NA & 537 & -43.0 & -8.08 & .140 \\
\hline 05056239 & ND-3 & 7 & .043 & -.002 & -5.67 & .249 & -.003 & -7.37 & .103 & NA & NA & 704 & -60.0 & -8.55 & .081 \\
\hline 05058700 & ND-4 & 7 & .151 & .012 & 7.65 & .456 & .007 & 4.51 & .623 & 279,000 & 43.2 & 34,000 & 254 & .75 & .936 \\
\hline 05064500 & $\mathrm{MN}-5$ & 7 & .436 & .046 & 10.60 & .208 & .043 & 9.93 & .203 & $3,380,000$ & 344 & 866,000 & 54,600 & 6.31 & .416 \\
\hline 05082500 & ND-6 & 8 & .421 & -.014 & -3.26 & .474 & -.018 & -4.25 & .293 & $3,990,000$ & 405 & $1,640,000$ & $-93,000$ & -5.64 & .165 \\
\hline 05114000 & ND-7 & 7 & .046 & -.001 & -.76 & .834 & .001 & 3.12 & .561 & 14,100 & 1.80 & 237 & NC & 61.71 & .122 \\
\hline 05120000 & ND-8 & 7 & .153 & -.009 & -6.10 & .062 & -.009 & -5.86 & .089 & 58,300 & 5.11 & 5,690 & -240 & -4.16 & .535 \\
\hline \multicolumn{16}{|c|}{ Central part } \\
\hline 04063700 & WI-9 & 7 & 0.044 & 0.001 & 1.57 & 0.447 & 0.001 & 1.54 & 0.439 & 7,330 & 20.4 & 3,680 & -74.0 & -2.01 & 0.310 \\
\hline 04067500 & WI-10 & 7 & .088 & -.002 & -2.58 & .172 & -.002 & -2.59 & .170 & 397,000 & 39.0 & 210,000 & $-5,500$ & -2.61 & .247 \\
\hline 04085427 & WI-12 & 7 & .231 & .027 & 11.51 & .304 & .024 & 10.24 & .330 & 518,000 & 380 & 30,300 & 1,310 & 4.32 & .650 \\
\hline 04087000 & WI-13 & 8 & .669 & .056 & 8.40 & .000 & .043 & 6.37 & .019 & 827,000 & 458 & 215,000 & 8,360 & 3.88 & .356 \\
\hline 05287890 & $\mathrm{MN}-14$ & 7 & .181 & .004 & 2.39 & .351 & -.003 & -1.56 & .536 & 24,100 & 108 & 3,840 & -240 & -6.19 & .086 \\
\hline 05340500 & WI-15 & 7 & .155 & .006 & 3.57 & .144 & .006 & 3.60 & .135 & 919,000 & 56.9 & 598,000 & 12,500 & 2.08 & .414 \\
\hline 05369500 & WI-16 & 7 & .554 & .013 & 2.32 & .053 & .015 & 2.78 & .028 & $4,700,000$ & 201 & $3,610,000$ & 40,500 & 1.12 & .452 \\
\hline 05382000 & WI-17 & 7 & .528 & .009 & 1.61 & .223 & .012 & 2.26 & .090 & 969,000 & 180 & 767,000 & $-16,000$ & -2.08 & .166 \\
\hline 05407000 & WI-20 & 7 & .645 & -.015 & -2.26 & .461 & -.013 & -2.04 & .483 & $7,470,000$ & 277 & $5,370,000$ & $-200,000$ & -3.79 & .147 \\
\hline 05420500 & IA-21 & 8 & 2.052 & -.049 & -2.41 & .253 & -.106 & -5.16 & .003 & $111,000,000$ & 502 & $117,000,000$ & $-7,700,000$ & -6.56 & .000 \\
\hline 05465500 & IA-25 & 8 & 3.982 & .481 & 12.07 & .006 & .040 & 1.00 & .786 & $71,400,000$ & 2,210 & $35,900,000$ & $-1,600,000$ & -4.50 & .261 \\
\hline 05474000 & IA-26 & 5 & 5.885 & .360 & 6.11 & .195 & -.328 & -5.57 & .174 & $18,600,000$ & 1,660 & $11,900,000$ & $-920,000$ & -7.72 & .059 \\
\hline 05514500 & MO-29 & 7 & .293 & .007 & 2.37 & .752 & .006 & 2.06 & .794 & $3,510,000$ & 1,500 & 32,600 & 478 & 1.47 & .896 \\
\hline 05540275 & IL-33 & 7 & .883 & -.046 & -5.24 & .000 & -.051 & -5.74 & .000 & 12,600 & 490 & 5,070 & -350 & -6.88 & .001 \\
\hline 05586100 & IL-37 & 9 & 3.364 & .077 & 2.28 & .038 & -.009 & -.27 & .802 & $119,000,000$ & 1,720 & $78,100,000$ & $-3,900,000$ & -4.97 & .011 \\
\hline 07018100 & MO-39 & 9 & .013 & .006 & 43.56 & .060 & .002 & 13.46 & .317 & 195,000 & 102 & 5,140 & 96.7 & 1.88 & .854 \\
\hline
\end{tabular}


Table 9. Summary of results for analyses of flow-adjusted trends, overall trends, and trends in loads for dissolved nitrite plus nitrate nitrogen (NO3, USGS parameter code 00631), 1993 to 2004.-Continued

[USGS, U.S. Geological Survey; ID, identification; mg/L, milligram per liter; mg/L/yr, milligram per liter per year; \%/yr, percent per year; kg, kilogram; kg/km², kilogram per square kilometer; $\mathrm{kg} / \mathrm{yr}$, kilogram per year; NA, not available; NC, not calculated; sites in bold indicate long-term evaluation sites]

\begin{tabular}{|c|c|c|c|c|c|c|c|c|c|c|c|c|c|c|c|}
\hline \multirow{3}{*}{$\begin{array}{c}\text { USGS } \\
\text { site } \\
\text { number }\end{array}$} & \multirow{3}{*}{$\begin{array}{c}\text { State-ID } \\
\text { number } \\
\text { (figure 1) }\end{array}$} & \multirow{3}{*}{$\begin{array}{c}\text { Water- } \\
\text { quality } \\
\text { model } \\
\text { (table 3) }\end{array}$} & \multicolumn{7}{|c|}{ Concentration } & \multirow{2}{*}{\multicolumn{6}{|c|}{ Annual loads }} \\
\hline & & & \multicolumn{4}{|c|}{ Flow-adjusted trend } & \multicolumn{3}{|c|}{ Overall trend } & & & & & & \\
\hline & & & $\begin{array}{c}\text { Reference } \\
\text { concentration } \\
\text { (mg/L) }\end{array}$ & $\begin{array}{c}\text { Trend } \\
\text { (mg/L/yr) }\end{array}$ & $\begin{array}{l}\text { Trend } \\
(\% / y r)\end{array}$ & p-value & $\begin{array}{c}\text { Trend } \\
\text { (mg/L/yr) }\end{array}$ & $\begin{array}{l}\text { Trend } \\
\text { (\%/yr) }\end{array}$ & p-value & $\begin{array}{c}\text { Median } \\
\text { annual } \\
\text { load } \\
(\mathbf{k g})\end{array}$ & $\begin{array}{c}\text { Median } \\
\text { yield } \\
\left(\mathbf{k g} / \mathbf{k m}^{2}\right)\end{array}$ & $\begin{array}{c}\text { Reference } \\
\text { load } \\
(\mathbf{k g})\end{array}$ & $\begin{array}{c}\text { Trend } \\
(\mathrm{kg} / \mathrm{yr})\end{array}$ & $\begin{array}{l}\text { Trend } \\
(\% / y r)\end{array}$ & p-value \\
\hline \multicolumn{16}{|c|}{ Eastern Part } \\
\hline 03085000 & PA-40 & 5 & 0.672 & 0.016 & 2.45 & 0.282 & 0.013 & 1.97 & 0.380 & $9,320,000$ & 490 & $4,500,000$ & 224,000 & 4.99 & 0.125 \\
\hline 03267900 & $\mathrm{OH}-41$ & 5 & 3.893 & -.032 & -.81 & .354 & .056 & 1.43 & .146 & $1,290,000$ & 1,610 & 585,000 & $\mathrm{NC}$ & 30.26 & .000 \\
\hline 03353637 & $\mathrm{IN}-42$ & 8 & .857 & -.030 & -3.50 & .000 & -.032 & -3.77 & .000 & 13,900 & 315 & 7,460 & -400 & -5.34 & .056 \\
\hline 04186500 & $\mathrm{OH}-43$ & 8 & 1.973 & .020 & 1.04 & .799 & .016 & .81 & .863 & $3,600,000$ & 4,190 & 141,000 & 623 & .44 & .952 \\
\hline 04193500 & OH-44 & 8 & 3.085 & -.077 & -2.48 & .405 & -.066 & -2.15 & .557 & $46,100,000$ & 2,810 & $5,760,000$ & $-99,000$ & -1.72 & .760 \\
\hline
\end{tabular}




\section{A. Flow-adjusted trend in concentrations}

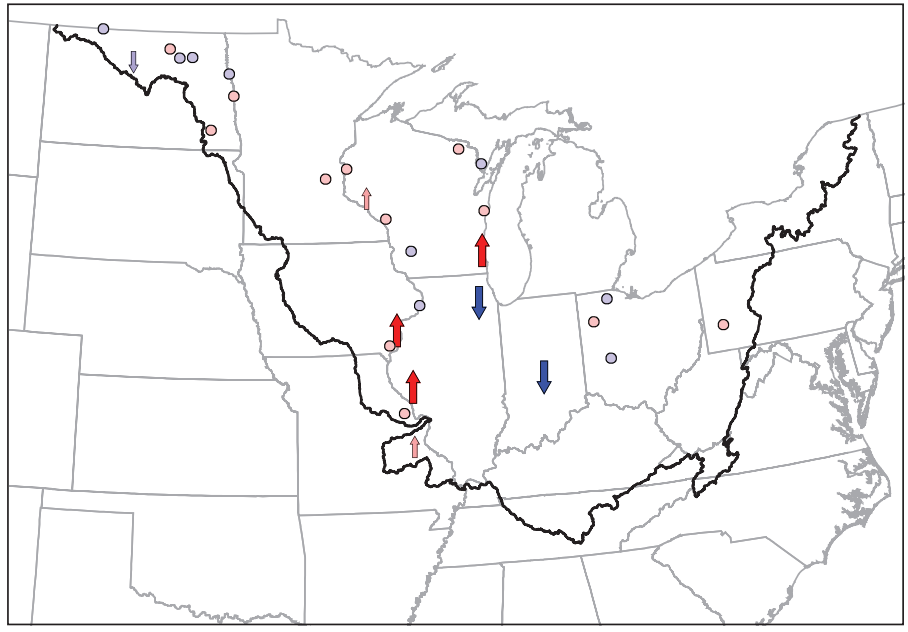

\section{DISSOLVED}

NITRITE PLUS NITRATE

\begin{tabular}{|l|}
\hline \multicolumn{1}{|c|}{ EXPLANATION } \\
Trends \\
$\uparrow$ Upward $(\mathrm{p}<0.05)$ \\
$\Uparrow$ Upward $(0.05 \leq \mathrm{p}<0.1)$ \\
$\circ$ Upward $(\mathrm{p} \geq 0.1)$ \\
$\circ$ Downward $(\mathrm{p} \geq 0.1)$ \\
$\Downarrow$ Downward $(0.05 \leq \mathrm{p}<0.1)$ \\
$\downarrow$ Downward $(\mathrm{p}<0.05)$
\end{tabular}

\section{B. Overall trend in concentrations}
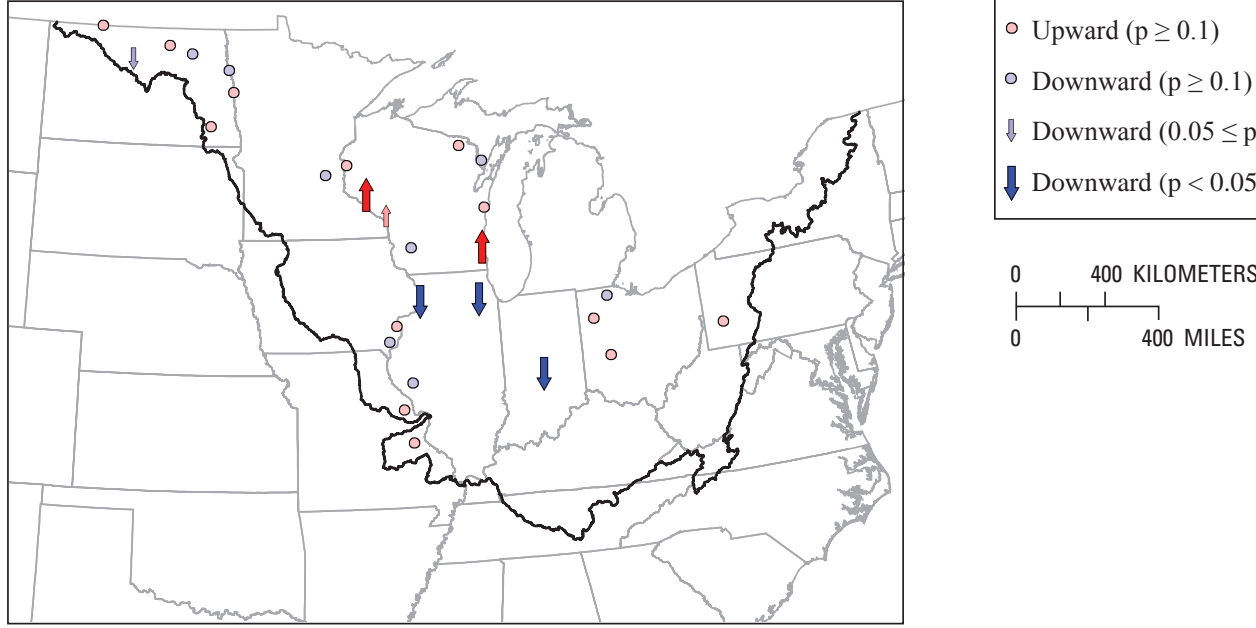

\section{Trend in annual loads}

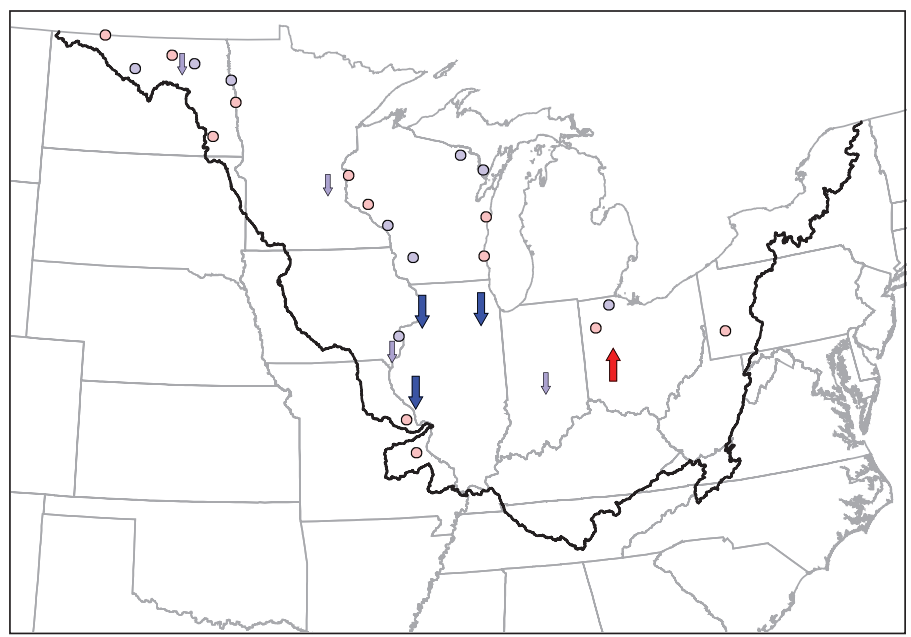

Figure 20. Trends in dissolved nitrite plus nitrate from 1993 to 2004 for $\boldsymbol{A}$, flow-adjusted concentrations, $\boldsymbol{B}$, overall concentrations, and $\boldsymbol{C}$, annual loads throughout the study area. 


\section{Trends in Dissolved Nitrite plus Nitrate Loads}

Of the 29 sites that had sufficient data from 1993 to 2004 for analysis, 16 sites had a tendency toward decreasing NO2NO3 loads, and 13 sites had a tendency toward increasing loads (table 9; fig. 20C). Seven of the sites with downward trends in loads had significant downward trends, whereas only one of the 12 sites with upward trends had a significant upward trend $(\mathrm{p}<0.10)$.

\section{Total Phosphorus}

\section{General Patterns in Total Phosphorus Concentrations and Yields}

Median midmonthly total phosphorus (TP) concentrations ranged from 0.005 to $4.45 \mathrm{mg} / \mathrm{L}$, based on water-quality data from all sites from 1970 to 2004 . The overall mean and median of the median TP concentrations were 0.17 and $0.11 \mathrm{mg} / \mathrm{L}$, respectively. High concentrations occurred throughout the study area, but especially at sites along a belt that spans North Dakota, southern Minnesota, Iowa, Illinois, Indiana, and Ohio (fig. 21A). The lowest concentrations occurred in forested areas of northern Wisconsin, Michigan, and Minnesota and along the eastern edge of the study area (figs. 5 and 21). The highest concentrations generally occurred in areas with large amounts of agriculture and urban land use. The spatial pattern in TP concentrations was similar to that for TN; however, sporadically high and low concentrations were found throughout the study area. Median midmonthly TP concentrations ranged from 0.028 to $1.49 \mathrm{mg} / \mathrm{L}$ at the 41 trend sites that had sufficient data for analysis from 1993 to 2004. The mean and median values of the median concentrations at these sites were 0.22 and $0.16 \mathrm{mg} / \mathrm{L}$, respectively. The distribution in concentrations of these sites was consistent with that in fig. $21 \mathrm{~A}$.

Median annual TP yields ranged from 0.421 to $1,950 \mathrm{~kg} / \mathrm{km}^{2}$, based on water-quality and streamflow data from all sites from 1970 to 2004 . The mean and median values of the median TP yields at these sites were 82.2 and $48.8 \mathrm{~kg} / \mathrm{km}^{2}$, respectively. The highest yields were throughout the southern one-half of the study area, especially through the middle of the study area (fig. $21 \boldsymbol{B}$ ). The lowest yields were throughout the northern one-half of the study area. Similar to $\mathrm{TN}$, the highest TP yields were in areas with intense row crop agriculture and moderate runoff. The areas with the highest runoff (fig. 3) had relatively low TP concentrations, such as in northern Wisconsin and southeastern parts of the study area. The major difference in the distributions in TP concentrations and yields was in the northwestern part of the study area, which had high concentrations but low yields, which can be attributed to lower runoff than other agricultural areas. Based on 1993 to 2003 data, median annual TP yields at the trend sites ranged from 2.65 to $649 \mathrm{~kg} / \mathrm{km}^{2}$ (table 10), which is within the range found for the entire data set. The distribution in yields was consistent with that in fig. $21 \boldsymbol{B}$. The mean and median values of the median yields at these trend sites were 86.3 and $44.8 \mathrm{~kg} / \mathrm{km}^{2}$, respectively.

\section{Trends in Total Phosphorus Concentrations}

From 1993 to 2004, FA trends in TP concentrations at 24 of the 40 sites that had sufficient data for analysis indicated a tendency toward increasing concentrations (table 10; fig. 22A). The 24 sites with increasing TP concentrations were distributed throughout the entire study area; however, most of these sites were in the central part and the eastern side of the western part of the study area. Twelve of the 24 sites had significant upward trends $(\mathrm{p}<0.10)$. These upward FA trends indicate that the effects of anthropogenic activities continue to increase in these areas and add additional TP to the streams. Concentrations at 7 of the 16 sites with downward trends were significant $(\mathrm{p}<0.10)$, indicating that the effects of anthropogenic activities were decreasing.

The OA trends in TP concentrations from 1993 to 2004 showed a general tendency toward increasing concentrations at 21 of the 41 sites (table 10; fig. 22B); however, the upward trends were significant at only 7 of these sites $(p<0.10)$. Of the 20 sites with downward trends, only 7 sites had significant trends. The sites with significant upward or downward trends were scattered throughout the study area.

The differences between FA trends and OA trends in TP concentrations are attributed to the trends in streamflow. The major difference was in the central part of the study areaseveral sites in Minnesota, Wisconsin, Illinois, Iowa, and Missouri had significant downward trends in streamflow (fig. 12). In this area, only four of the nine sites that had statistically significant FA trends in TP concentrations had statistically significant OA trends in concentrations. Very few changes occurred in the other parts of the study area.

To place the 1993 to 2004 trends in TP concentrations into a longer term context, FACs were computed from 1975 to 2004 for the six sites with sufficient data and examined for trends with QWTREND (table 11; fig. 23). Three sites had little or no trend from 1975 to 2004; the Iowa River (05465500) and Mississippi River (05420500) showed no trend, and the Chippewa River (05369500) had a downward trend from 1975 to 1985 and no trend after that. The Souris River (05114000) site had no trend from 1975 to 1979 , then a downward trend until 1988 and an upward trend through 2004. The Milwaukee River (04087000) had a downward trend from 1975 through 1995 and then an upward trend though 2004. The Maumee River (04193500) had a very strong downward trend from 1975 through 1982, followed by an upward trend until 1989, and another downward trend through 2004. The flow-adjusted concentration in the Maumee River in 2004 was less than onehalf of the flow-adjusted concentration in 1975 (table 11). 


\section{A. Median total phosphorus concentrations}

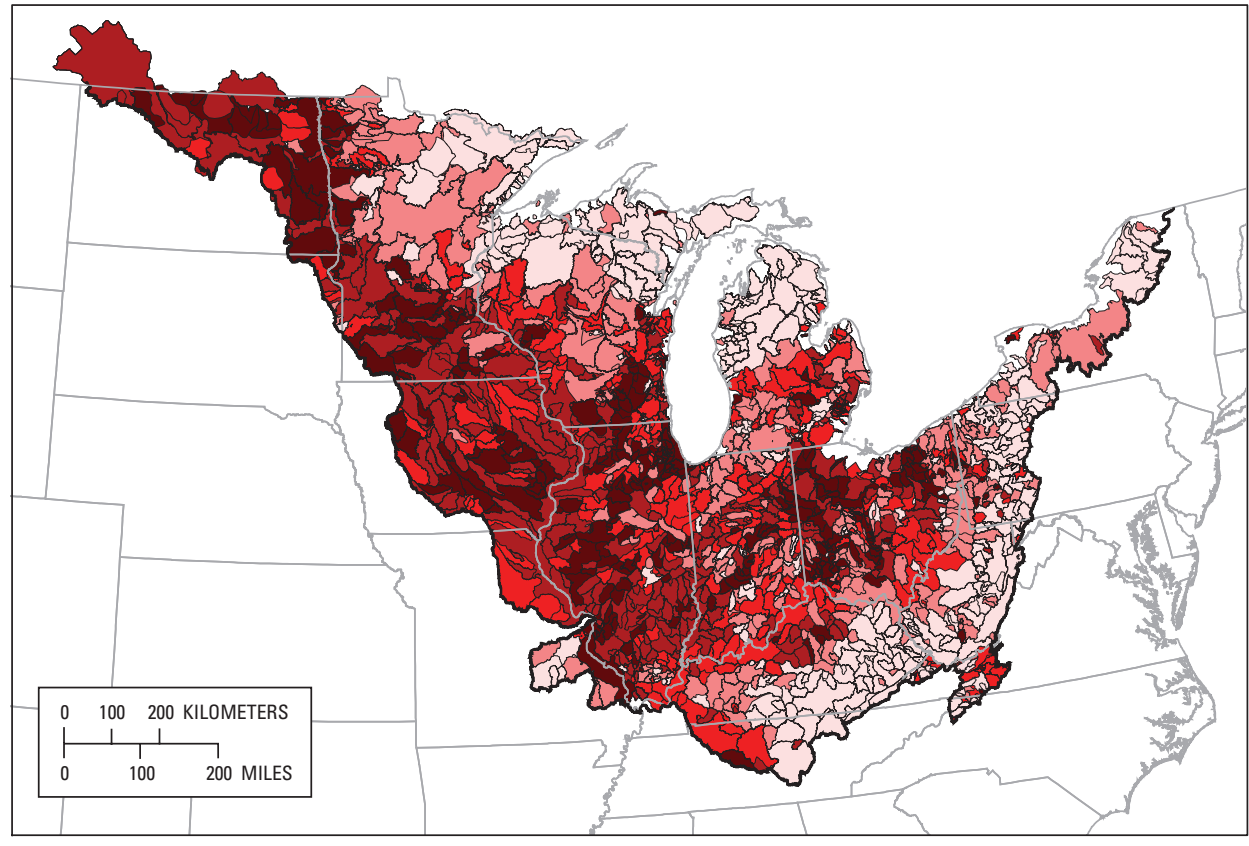

\section{B. Median annual total phosphorus yields}

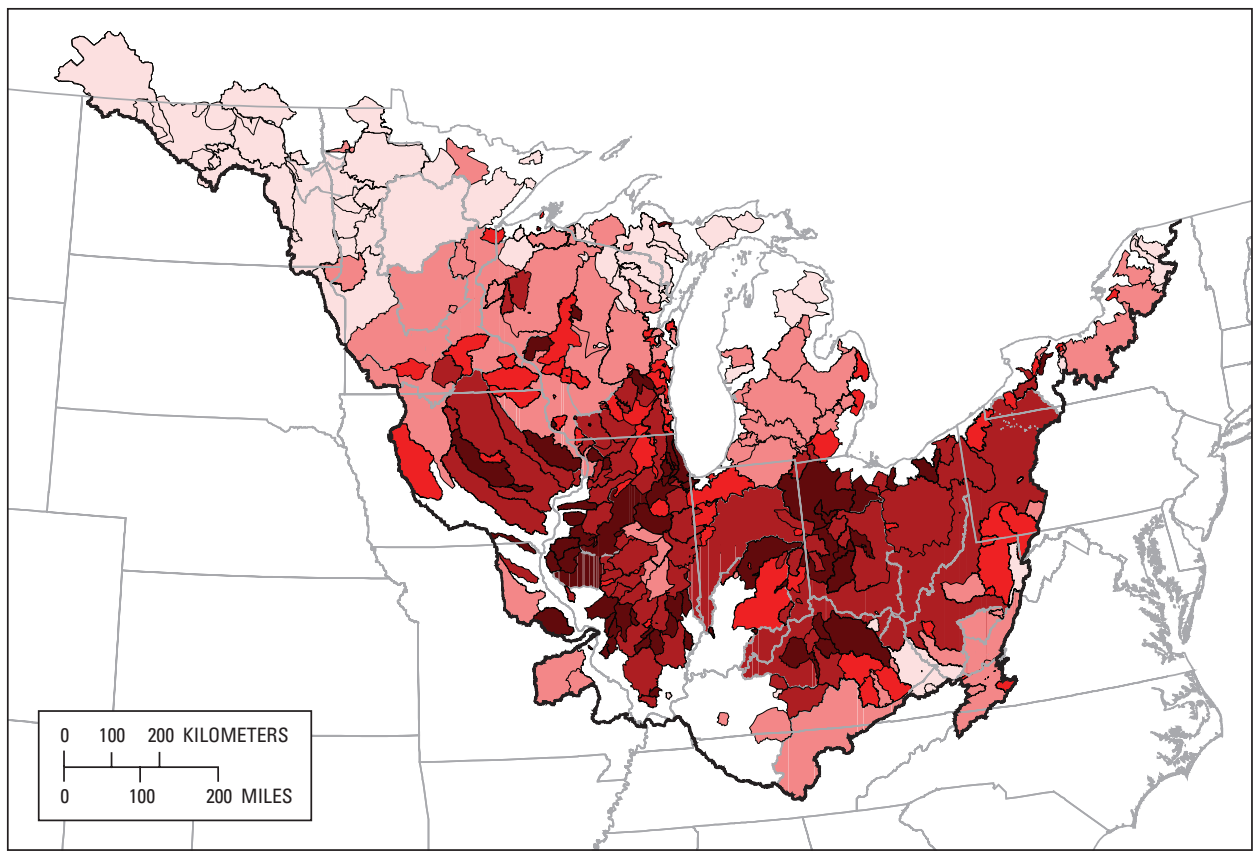

\section{EXPLANATION}

Median total phosphorus concentration, in millgrams per liter

$\square .005-0.040$
$\square .041-0.080$
$0.081-0.145$
$0.146-0.230$
$0.231-4.450$

- Study area
$-\quad$ State boundary
- Basin boundary

\section{EXPLANATION}

Median annual total phosphorus yield, in kilograms per square kilometer

$\square$
$\square .421-15.0$
$15.1-35.6$
$35.7-58.9$
$59.0-105$
$106-1,950$

$-\quad$ Study area
$-\quad$ State boundary
$-\quad$ Basin boundary

Figure 21. Spatial patterns from 1970 to 2004 in $\boldsymbol{A}$, median total phosphorus concentrations and $\boldsymbol{B}$, median annual total phosphorus yields throughout the study area. 
Table 10. Summary of results for analyses of flow-adjusted trends, overall trends, and trends in loads for total phosphorus (TP, USGS parameter code 00665), 1993 to 2004.

[USGS, U.S. Geological Survey; ID, identification; mg/L, milligram per liter; mg/L/yr, milligram per liter per year; \%/yr, percent per year; kg, kilogram; kg/km², kilogram per square kilometer; $\mathrm{kg} / \mathrm{yr}$, kilogram per year; NA, not available; $\mathrm{NC}$, not calculated; sites in bold indicate long-term evaluation sites]

\begin{tabular}{|c|c|c|c|c|c|c|c|c|c|c|c|c|c|c|c|}
\hline \multirow{3}{*}{$\begin{array}{l}\text { USGS } \\
\text { site } \\
\text { number }\end{array}$} & \multirow{3}{*}{$\begin{array}{l}\text { State-ID } \\
\text { number } \\
\text { (figure 1) }\end{array}$} & \multirow{3}{*}{$\begin{array}{l}\text { Water- } \\
\text { quality } \\
\text { model } \\
\text { (table 3) }\end{array}$} & \multicolumn{7}{|c|}{ Concentration } & \multirow{2}{*}{\multicolumn{6}{|c|}{ Annual loads }} \\
\hline & & & \multicolumn{4}{|c|}{ Flow-adjusted trend } & \multicolumn{3}{|c|}{ Overall trend } & & & & & & \\
\hline & & & $\begin{array}{c}\text { Reference } \\
\text { concentration } \\
\text { (mg/L) }\end{array}$ & $\begin{array}{c}\text { Trend } \\
\text { (mg/L/yr) }\end{array}$ & $\begin{array}{l}\text { Trend } \\
\text { (\%/yr) }\end{array}$ & p-value & $\begin{array}{c}\text { Trend } \\
\text { (mg/L/yr) }\end{array}$ & $\begin{array}{l}\text { Trend } \\
\text { (\%/yr) }\end{array}$ & p-value & $\begin{array}{c}\text { Median } \\
\text { annual } \\
\text { load } \\
(\mathrm{kg})\end{array}$ & $\begin{array}{l}\text { Median } \\
\text { yield } \\
\left(\mathbf{k g} / \mathbf{k m}^{2}\right)\end{array}$ & $\begin{array}{c}\text { Reference } \\
\text { load } \\
(\mathrm{kg})\end{array}$ & $\begin{array}{l}\text { Trend } \\
(\mathrm{kg} / \mathrm{yr})\end{array}$ & $\begin{array}{l}\text { Trend } \\
\text { (\%/yr) }\end{array}$ & p-value \\
\hline \multicolumn{16}{|c|}{ Western part } \\
\hline 05056100 & ND-1 & 7 & 0.362 & 0.001 & 0.11 & 0.960 & 0.001 & 0.28 & 0.898 & NA & NA & 3,430 & -160 & -4.79 & 0.455 \\
\hline 05056200 & ND-2 & 5 & .302 & .011 & 3.66 & .183 & .015 & 4.83 & .095 & NA & NA & 5,040 & -300 & -5.88 & .309 \\
\hline 05056239 & ND-3 & 3 & .231 & .008 & 3.39 & .370 & .005 & 2.05 & .581 & NA & NA & 4,100 & -250 & -6.01 & .314 \\
\hline 05058700 & ND-4 & 3 & .187 & .002 & .89 & .854 & -.001 & -.11 & .980 & 141,000 & 21.8 & 42,600 & $-1,100$ & -2.58 & .632 \\
\hline 05064500 & MN-5 & 7 & .186 & .019 & 10.14 & .033 & .017 & 9.15 & .032 & $1,200,000$ & 122 & 369,000 & 21,000 & 5.67 & .279 \\
\hline 05082500 & ND-6 & 5 & .151 & .012 & 7.83 & .062 & .008 & 5.42 & .159 & $1,510,000$ & 153 & 590,000 & 6,710 & 1.14 & .807 \\
\hline 05114000 & ND-7 & 9 & .385 & -.010 & -2.70 & .061 & -.011 & -2.91 & .059 & 20,800 & 2.65 & 2,130 & NC & 25.80 & .185 \\
\hline 05120000 & ND-8 & 9 & .263 & -.003 & -1.09 & .483 & -.002 & -.93 & .550 & 30,400 & 2.67 & 9,980 & 379 & 3.80 & .630 \\
\hline \multicolumn{16}{|c|}{ Central part } \\
\hline 04063700 & WI-9 & 3 & 0.025 & -0.001 & -2.00 & 0.374 & -0.001 & -2.83 & 0.220 & 2,410 & 6.70 & 2,090 & -100 & -4.87 & 0.028 \\
\hline 04067500 & WI-10 & 1 & .027 & NA & NA & NA & -.001 & -.01 & .977 & 79,100 & 7.76 & 64,800 & -25.0 & -.04 & .977 \\
\hline 04073468 & WI-11 & 8 & .131 & -.003 & -2.00 & .000 & -.003 & -2.13 & .000 & 4,050 & 29.2 & 3,480 & -130 & -3.86 & .079 \\
\hline 04085427 & WI-12 & 7 & .184 & -.002 & -.85 & .739 & -.002 & -1.25 & .609 & 40,700 & 29.9 & 24,100 & -870 & -3.60 & .269 \\
\hline 04087000 & WI-13 & 8 & .091 & .001 & .63 & .463 & .001 & .55 & .519 & 49,500 & 27.5 & 29,400 & -290 & -.98 & .617 \\
\hline 05287890 & MN-14 & 9 & .135 & .004 & 2.68 & .016 & .001 & .47 & .713 & 8,420 & 37.8 & 3,080 & -160 & -5.33 & .091 \\
\hline 05340500 & WI-15 & 5 & .028 & .003 & 11.71 & .003 & .003 & 9.71 & .011 & 225,000 & 13.9 & 101,000 & 7,800 & 7.69 & .076 \\
\hline 05369500 & WI-16 & 7 & .084 & .001 & .57 & .510 & .001 & .24 & .792 & 737,000 & 31.6 & 545,000 & $-5,700$ & -1.05 & .528 \\
\hline 05382000 & WI-17 & 9 & .124 & .003 & 2.34 & .013 & .001 & 1.17 & .198 & 259,000 & 48.0 & 180,000 & $-4,900$ & -2.73 & .086 \\
\hline 05407000 & WI-20 & 7 & .086 & -.001 & -.75 & .635 & -.001 & -1.18 & .397 & 709,000 & 26.3 & 713,000 & $-22,000$ & -3.15 & .036 \\
\hline 05420500 & IA-21 & 9 & .183 & -.001 & -.07 & .952 & -.002 & -.99 & .361 & $9,230,000$ & 41.6 & $10,800,000$ & $-420,000$ & -3.86 & .002 \\
\hline 05427718 & WI-22 & 9 & .143 & .001 & .02 & .974 & -.005 & -3.34 & .003 & 7,280 & 38.2 & 3,290 & -160 & -5.01 & .001 \\
\hline 05427948 & WI-23 & 5 & .377 & -.020 & -5.32 & .000 & -.021 & -5.44 & .000 & 3,700 & 83.5 & 1,070 & -60.0 & -5.62 & .000 \\
\hline 054310157 & WI-24 & 8 & .130 & -.002 & -1.69 & .054 & -.002 & -1.60 & .228 & 1,000 & 89.3 & 159 & -2.20 & -1.39 & .677 \\
\hline 05465500 & IA-25 & 3 & .227 & .014 & 6.22 & .002 & .009 & 4.11 & .022 & $2,570,000$ & 79.4 & $2,070,000$ & $-65,000$ & -3.14 & .251 \\
\hline 05474000 & IA-26 & 9 & .142 & .013 & 9.26 & .008 & .005 & 3.53 & .281 & $1,160,000$ & 104 & 293,000 & $-14,000$ & -4.92 & .218 \\
\hline
\end{tabular}


Table 10. Summary of results for analyses of flow-adjusted trends, overall trends, and trends in loads for total phosphorus (TP, USGS parameter code 00665), 1993 to 2004.-Continued

[USGS, U.S. Geological Survey; ID, identification; mg/L, milligram per liter; mg/L/yr, milligram per liter per year; \%/yr, percent per year; kg, kilogram; kg/km², kilogram per square kilometer; $\mathrm{kg} / \mathrm{yr}$, kilogram per year; NA, not available; NC, not calculated; sites in bold indicate long-term evaluation sites]

\begin{tabular}{|c|c|c|c|c|c|c|c|c|c|c|c|c|c|c|c|}
\hline \multirow{3}{*}{$\begin{array}{l}\text { USGS } \\
\text { site } \\
\text { number }\end{array}$} & \multirow{3}{*}{$\begin{array}{c}\text { State-ID } \\
\text { number } \\
\text { (figure 1) }\end{array}$} & \multirow{3}{*}{$\begin{array}{c}\text { Water- } \\
\text { quality } \\
\text { model } \\
\text { (table 3) }\end{array}$} & \multicolumn{7}{|c|}{ Concentration } & \multirow{2}{*}{\multicolumn{6}{|c|}{ Annual loads }} \\
\hline & & & \multicolumn{4}{|c|}{ Flow-adjusted trend } & \multicolumn{3}{|c|}{ Overall trend } & & & & & & \\
\hline & & & $\begin{array}{c}\text { Reference } \\
\text { concentration } \\
\text { (mg/L) }\end{array}$ & $\begin{array}{c}\text { Trend } \\
\text { (mg/L/yr) }\end{array}$ & $\begin{array}{l}\text { Trend } \\
(\% / y r)\end{array}$ & p-value & $\begin{array}{c}\text { Trend } \\
\text { (mg/L/yr) }\end{array}$ & $\begin{array}{l}\text { Trend } \\
(\% / y r)\end{array}$ & p-value & $\begin{array}{c}\text { Median } \\
\text { annual } \\
\text { load } \\
(\mathrm{kg})\end{array}$ & $\begin{array}{c}\text { Median } \\
\text { yield } \\
\left(\mathbf{k g} / \mathbf{k m}^{2}\right)\end{array}$ & $\begin{array}{c}\text { Reference } \\
\text { load } \\
(\mathrm{kg})\end{array}$ & $\begin{array}{l}\text { Trend } \\
(\mathrm{kg} / \mathrm{yr})\end{array}$ & $\begin{array}{l}\text { Trend } \\
(\% / y r)\end{array}$ & p-value \\
\hline \multicolumn{16}{|c|}{ Central part-continued } \\
\hline 05500000 & MO-28 & 8 & 0.098 & 0.004 & 4.43 & 0.011 & -0.001 & -0.56 & 0.794 & 243,000 & 151 & 12,900 & -840 & -6.51 & 0.078 \\
\hline 05514500 & MO-29 & 7 & .121 & -.001 & -.11 & .972 & -.001 & -.34 & .930 & 385,000 & 164 & 13,500 & -110 & -.84 & .919 \\
\hline 05525500 & IL-30 & 8 & .057 & .003 & 5.11 & .024 & .002 & 3.11 & .283 & 209,000 & 181 & 8,160 & -75.0 & -.91 & .885 \\
\hline 05531500 & IL-31 & 9 & .887 & .009 & 1.00 & .448 & .012 & 1.39 & .387 & 193,000 & 649 & 108,000 & 898 & .83 & .544 \\
\hline 05532500 & IL-32 & 9 & .458 & .012 & 2.68 & .040 & .019 & 4.08 & .020 & 439,000 & 269 & 238,000 & 4,210 & 1.77 & .215 \\
\hline 05540275 & IL-33 & 9 & .076 & -.001 & -.21 & .891 & -.001 & -1.07 & .488 & 990 & 38.6 & 435 & -18.0 & -4.09 & .139 \\
\hline 05552500 & IL-35 & 5 & .214 & .006 & 3.00 & .641 & .007 & 3.37 & .599 & 555,000 & 84.3 & 399,000 & $-6,400$ & -1.60 & .791 \\
\hline 05586100 & IL-37 & 9 & .258 & .022 & 8.38 & .000 & .022 & 8.66 & .000 & $8,580,000$ & 124 & $6,410,000$ & $-57,000$ & -.89 & .676 \\
\hline 07018100 & MO-39 & 5 & .031 & -.001 & -.43 & .805 & -.001 & -1.52 & .340 & 71,100 & 37.4 & 14,600 & -780 & -5.35 & .007 \\
\hline \multicolumn{16}{|c|}{ Eastern part } \\
\hline 03085000 & PA-40 & 5 & 0.018 & 0.002 & 9.08 & 0.134 & 0.002 & 9.66 & 0.113 & 578,000 & 30.4 & 121,000 & $\mathrm{NC}$ & 14.85 & 0.063 \\
\hline 03353637 & IN-42 & 9 & .024 & .001 & 1.83 & .236 & .001 & .26 & .901 & 3,420 & 77.5 & 207 & -5.40 & -2.63 & .566 \\
\hline 04186500 & $\mathrm{OH}-43$ & 8 & .132 & -.002 & -1.71 & .383 & -.002 & -1.78 & .398 & 81,900 & 95.3 & 10,100 & -210 & -2.07 & .657 \\
\hline 04193500 & OH-44 & 8 & .135 & .001 & .03 & .985 & .001 & .26 & .903 & $1,930,000$ & 118 & 255,000 & 2,160 & .85 & .854 \\
\hline 0422026250 & NY-45 & 9 & .390 & -.011 & -2.69 & .000 & -.013 & -3.30 & .000 & 3,240 & 124 & 2,470 & 7.48 & .30 & .870 \\
\hline 04232034 & NY-46 & 7 & .070 & -.002 & -2.35 & .046 & -.002 & -2.71 & .033 & 3,530 & 34.8 & 1,850 & -62.0 & -3.33 & .083 \\
\hline 0423204920 & NY-47 & 8 & .090 & -.001 & -1.56 & .052 & -.002 & -1.93 & .027 & 1,210 & 67.1 & 425 & -15.0 & -3.54 & .093 \\
\hline 0423205025 & NY-48 & 8 & .068 & .004 & 5.27 & .000 & .003 & 4.17 & .000 & 14,200 & 38.2 & 6,570 & 83.3 & 1.27 & .585 \\
\hline
\end{tabular}




\section{A. Flow-adjusted trend in concentrations}

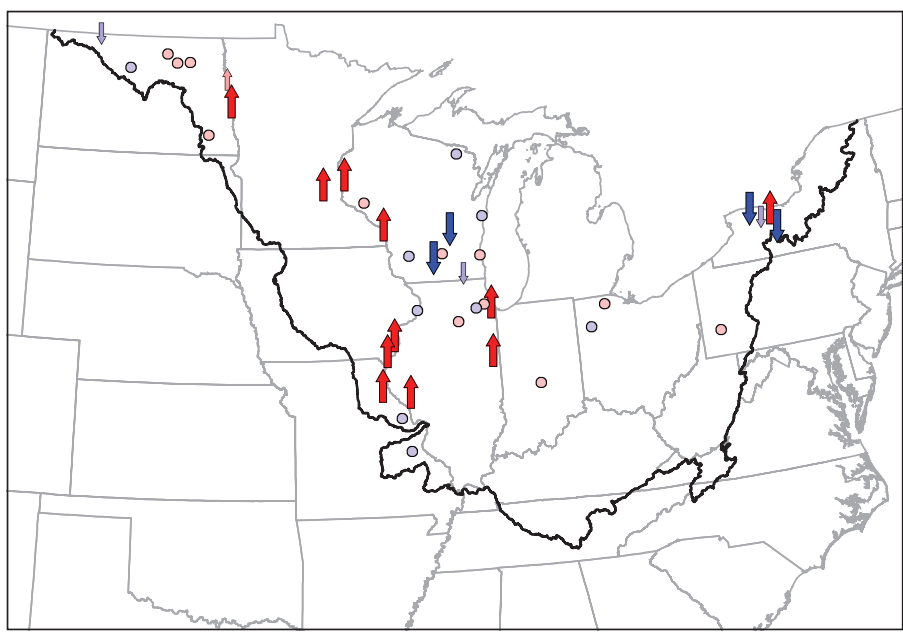

\section{B. Overall trend in concentrations}

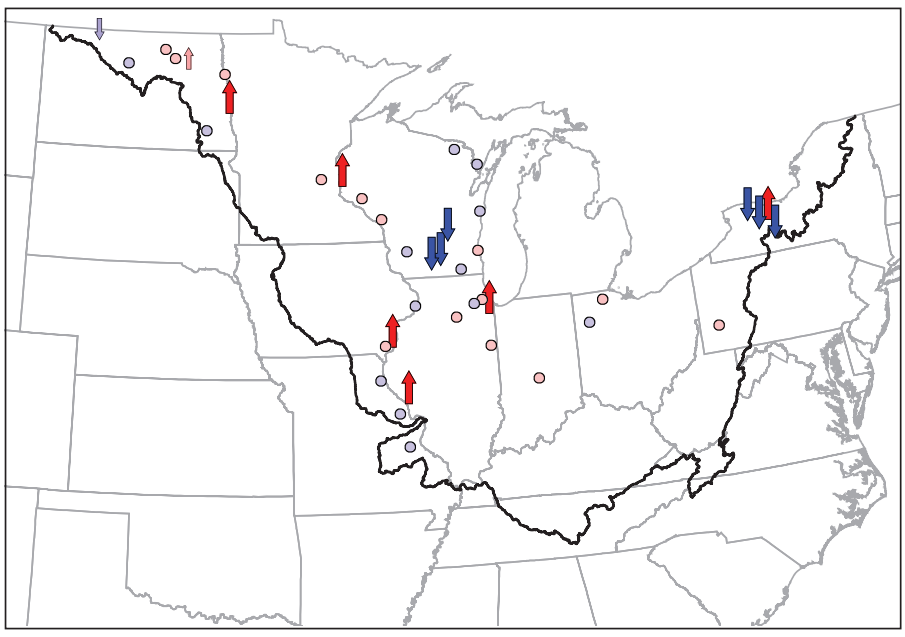

\section{Trend in annual loads}

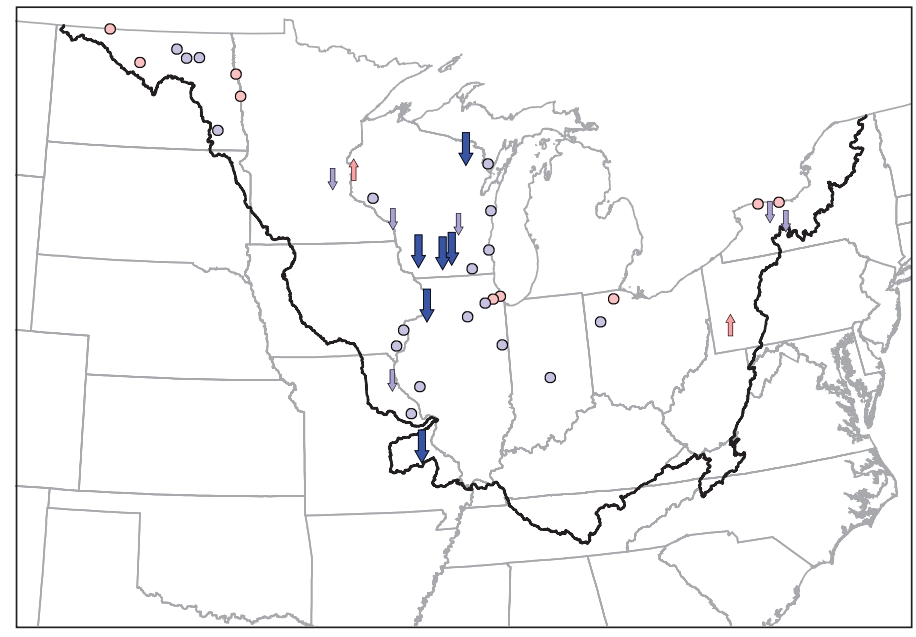

TOTAL PHOSPHORUS

EXPLANATION

Trends

Upward $(\mathrm{p}<0.05)$

iิ Upward $(0.05 \leq \mathrm{p}<0.1)$

○ $\operatorname{Upward}(\mathrm{p} \geq 0.1)$

○ Downward $(\mathrm{p} \geq 0.1)$

ป Downward $(0.05 \leq \mathrm{p}<0.1)$

$\checkmark$ Downward $(\mathrm{p}<0.05)$

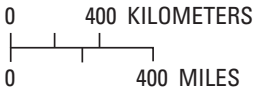

Figure 22. Trends in total phosphorus from 1993 to 2004 for $\boldsymbol{A}$, flow-adjusted concentrations, $\boldsymbol{B}$, overall concentrations, and $\boldsymbol{C}$, annual loads throughout the study area. 
A.
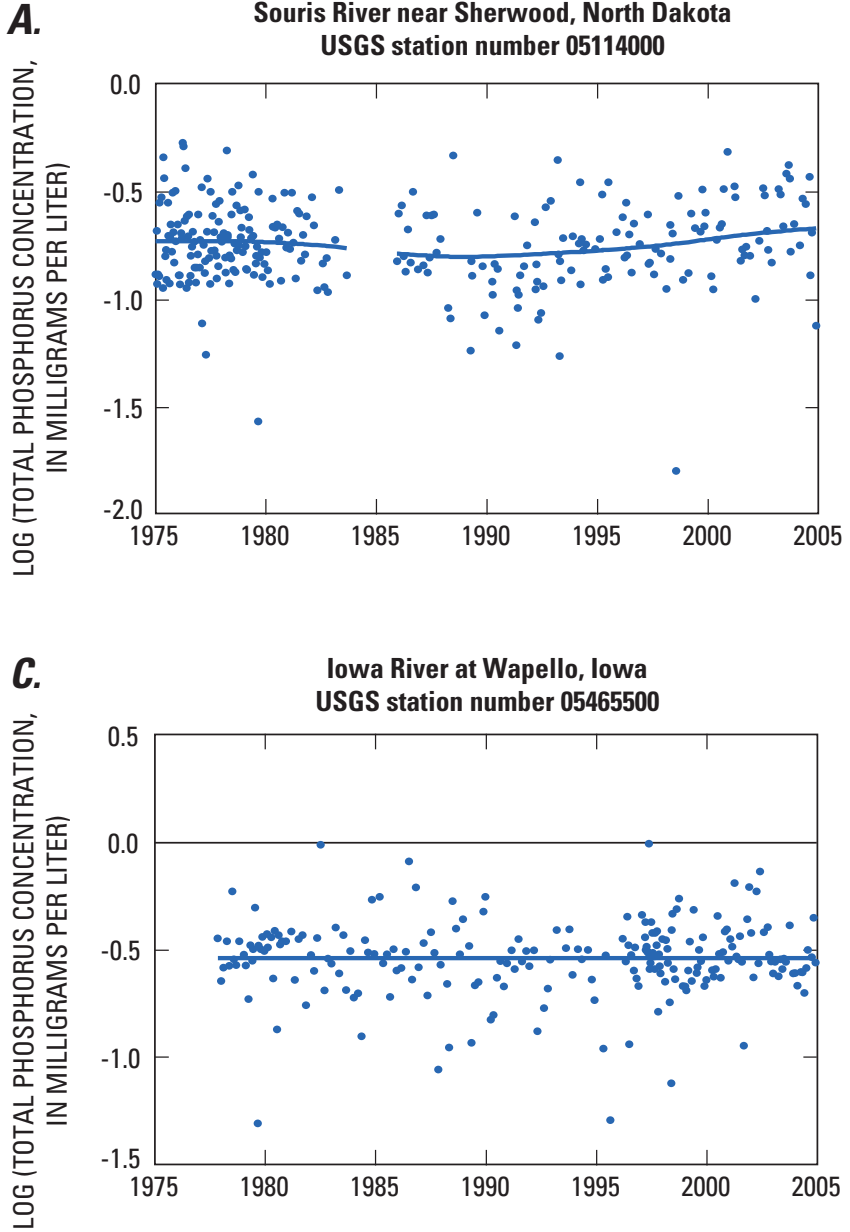

E.

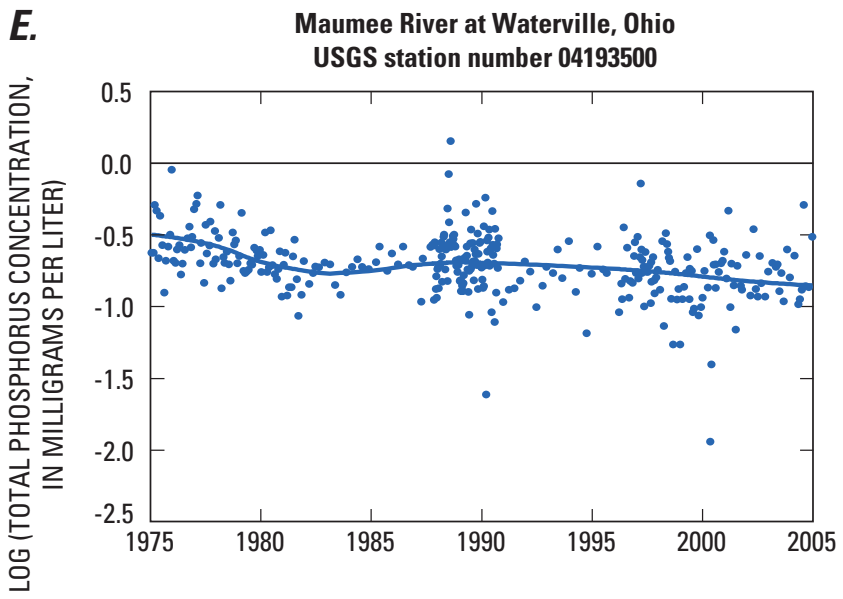

B.

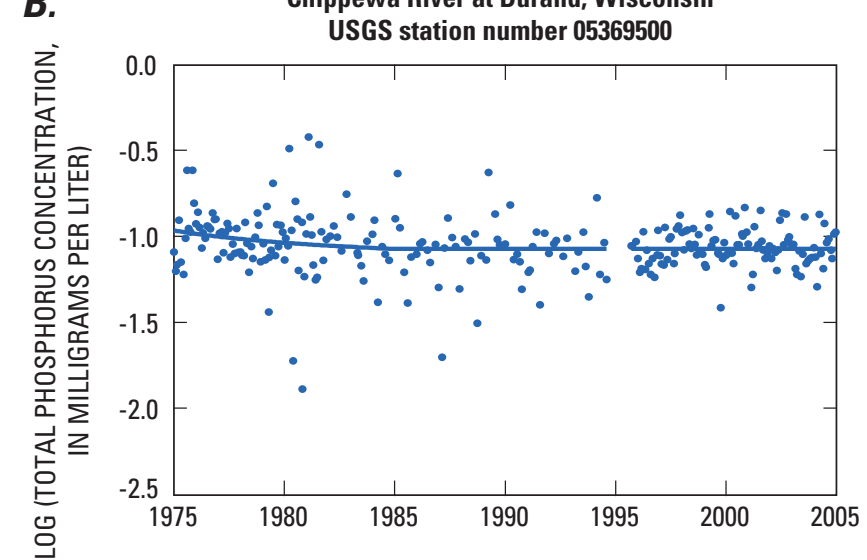

D.

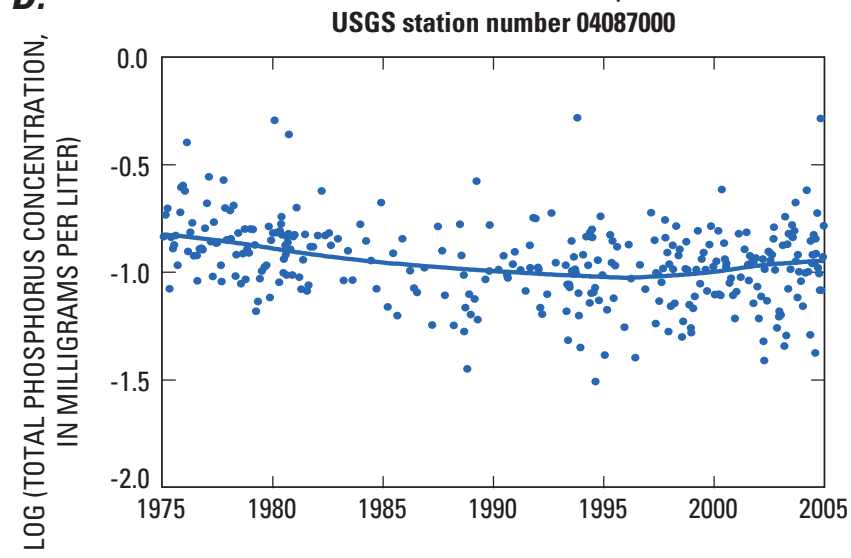

F. Mississippi River at Clinton, lowa

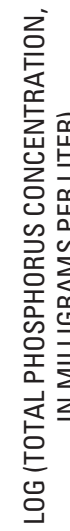

USGS station number 05420500

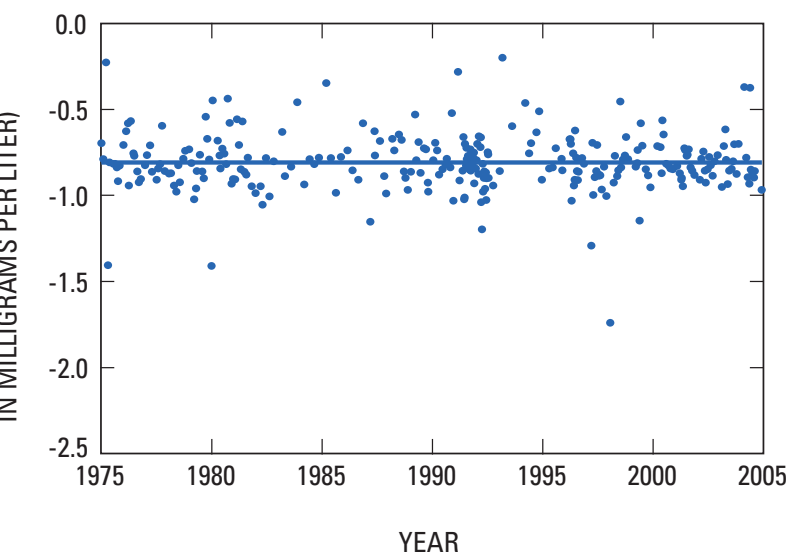

EXPLANATION

- LOESS smoothing line

- Concentration

Figure 23. Long-term flow-adjusted trends in total phosphorus concentrations from 1975 to 2004 at six selected sites in the study area. 
Table 11. Summary of flow-adjusted trends in total phosphorus concentrations (TP, USGS parameter code 00665) estimated by QWTREND for long-term evaluation sites, 1975 to 2004.

[USGS, U.S. Geological Survey; mg/L, milligram per liter]

\begin{tabular}{|c|c|c|}
\hline $\begin{array}{l}\text { USGS site } \\
\text { number }\end{array}$ & Trend period & Description of flow-adjusted concentration \\
\hline \multirow[t]{3}{*}{05114000} & January 1975-December 1978 & Constant value of $0.19 \mathrm{mg} / \mathrm{L}$ \\
\hline & January 1979-December 1988 & Downward trend from 0.19 to $0.16 \mathrm{mg} / \mathrm{L}$ \\
\hline & January 1989-December 2004 & Upward trend from 0.16 to $0.22 \mathrm{mg} / \mathrm{L}$ \\
\hline \multirow[t]{2}{*}{05369500} & January 1975-December 1984 & Downward trend from 0.11 to $0.09 \mathrm{mg} / \mathrm{L}$ \\
\hline & January 1985-December 2004 & Constant value of $0.09 \mathrm{mg} / \mathrm{L}$ \\
\hline 05465500 & November 1977-December 2004 & Constant value of $0.29 \mathrm{mg} / \mathrm{L}$ \\
\hline \multirow[t]{2}{*}{04087000} & January 1975-December 1995 & Downward trend from 0.15 to $0.09 \mathrm{mg} / \mathrm{L}$ \\
\hline & January 1996-December 2004 & Upward trend from 0.09 to $0.11 \mathrm{mg} / \mathrm{L}$ \\
\hline \multirow[t]{3}{*}{04193500} & January 1975-December 1982 & Downward trend from 0.32 to $0.17 \mathrm{mg} / \mathrm{L}$ \\
\hline & January 1983-December 1988 & Upward trend from 0.17 to $0.21 \mathrm{mg} / \mathrm{L}$ \\
\hline & January 1989-December 2004 & Downward trend from 0.21 to $0.14 \mathrm{mg} / \mathrm{L}$ \\
\hline 05420500 & January 1975-December 2004 & Constant value of $0.16 \mathrm{mg} / \mathrm{L}$ \\
\hline
\end{tabular}

\section{Trends in Total Phosphorus Loads}

From 1993 to 2004 , TP loads at 30 of the 41 sites that had sufficient data for analysis indicated a tendency toward decreasing loads (table 10; fig. 22C). Twelve of these sites, all within the central and eastern parts of the study area, had significant $(p<0.10)$ downward trends in loads. Most of these sites had significant downward trends in streamflow. The trends at only 2 of the 11 sites that had upward trends were statistically significant $(\mathrm{p}<0.10)$. A comparison of the trends in loads and FA trends in concentrations indicates that most of the trends in loads were driven primarily by streamflow rather than by changes in concentrations, except in southern Wisconsin where trends in both streamflow and concentration were significantly downward.

Annual loads at the six long-term sites from 1975 to 2003 were used to put the short-term trends in TP loads into a longer term context (fig. 24). The long-term changes at all six sites resembled the long-term trend in streamflow (fig. 13), which again indicates the importance of changes in streamflow in driving the trends in loads. Total phosphorus loads at the Souris River, N. Dak., probably were affected by the construction of dams within the basin during the 1990s. Loads at the Souris River, N. Dak., were more variable from 1975 to 1983 and from 1996 to 2004, producing larger average loads during those periods than from 1984 to 1995 . Loads at the Milwaukee River, Wis., showed a decrease between 1982 and 1990. Loads at the remaining four sites varied slightly and showed no sustained trends.

\section{Dissolved Phosphorus}

\section{General Patterns in Dissolved Phosphorus Concentrations and Yields}

Median midmonthly dissolved phosphorus (DP) concentrations at the 35 trend sites that had sufficient data for analysis ranged from 0.020 to $1.29 \mathrm{mg} / \mathrm{L}$, based on data from 1993 to 2004 . The mean and median values of the median DP concentrations at these trend sites were 0.149 and $0.075 \mathrm{mg} / \mathrm{L}$, respectively. The highest DP concentrations were in central Illinois and eastern North Dakota; whereas the lowest concentrations $(<0.1 \mathrm{mg} / \mathrm{L})$ were in all three parts of the study area. The highest concentrations were in areas with intensive agriculture, and the lowest concentrations were in forested areas.

Median annual DP yields ranged from 2.39 to $496 \mathrm{~kg} / \mathrm{km}^{2}$, based on data from 1993 to 2003 (table 12). The mean and median values of the median DP yields at these trend sites were 48.3 and $19.0 \mathrm{~kg} / \mathrm{km}^{2}$, respectively. Five of the six sites with the highest yields were in Illinois, and the remaining high-yield site was in North Dakota. The lowest yields were from sites throughout the north-central and eastern parts of the study area; especially low yields were from two sites in northern Wisconsin and one site in New York. 
A

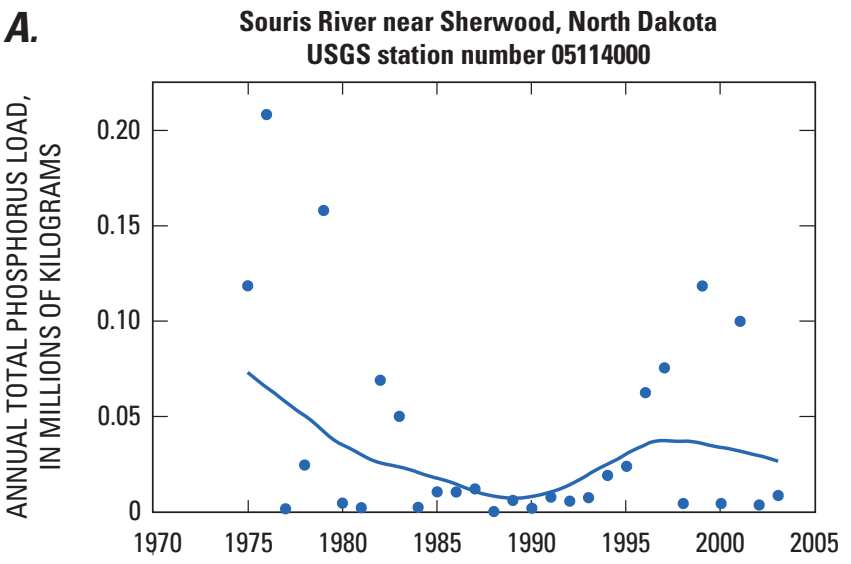

C.

lowa River at Wapello, lowa USGS station number 05465500

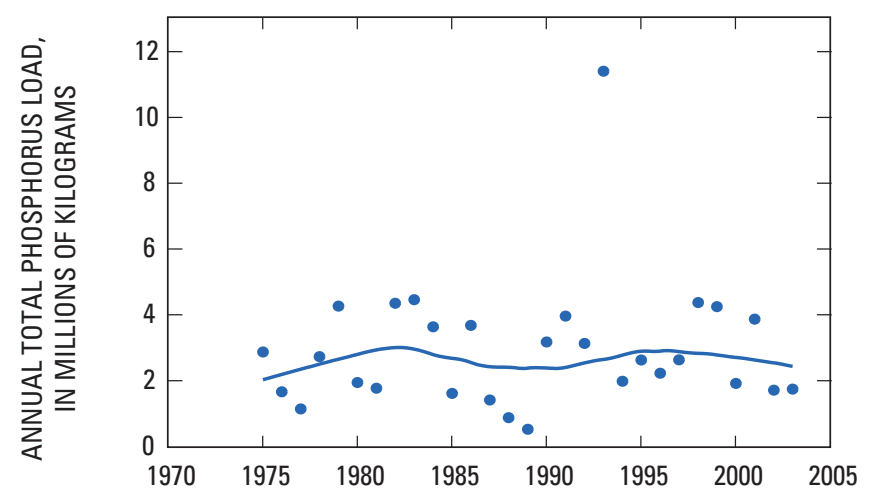

E.
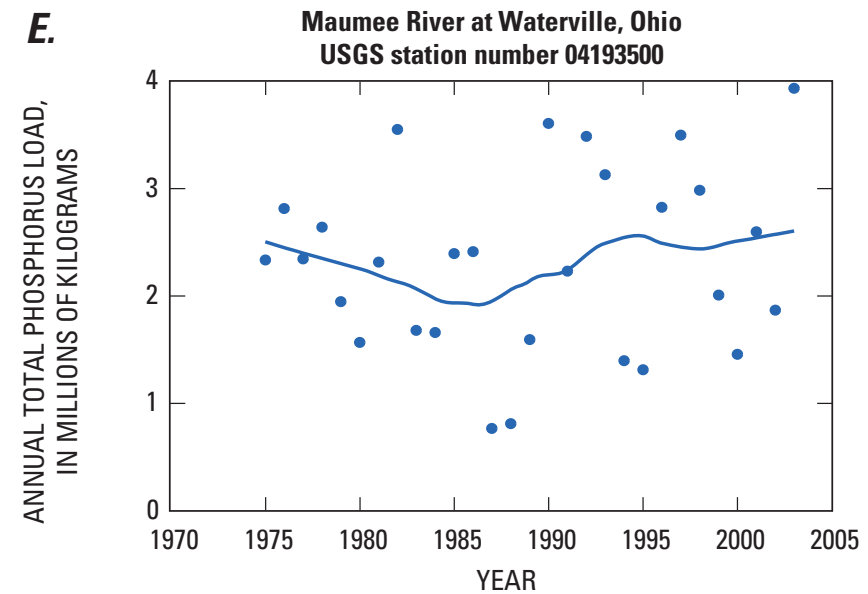

B.

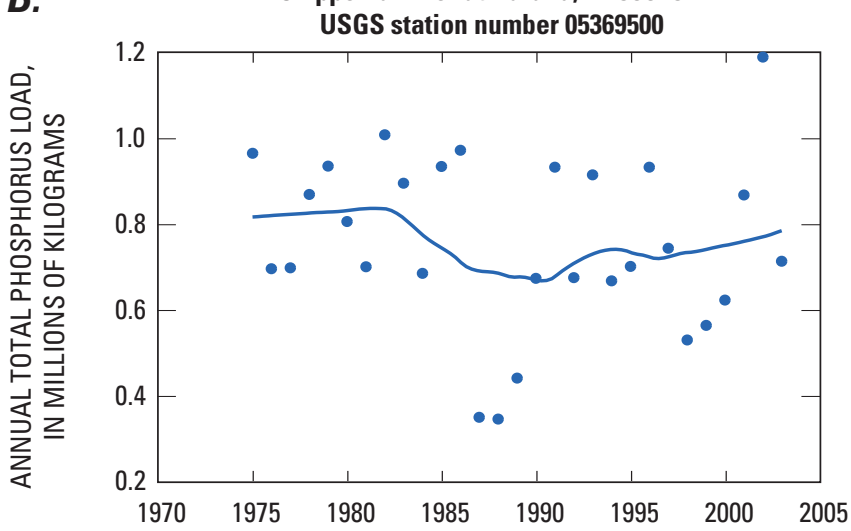

D.

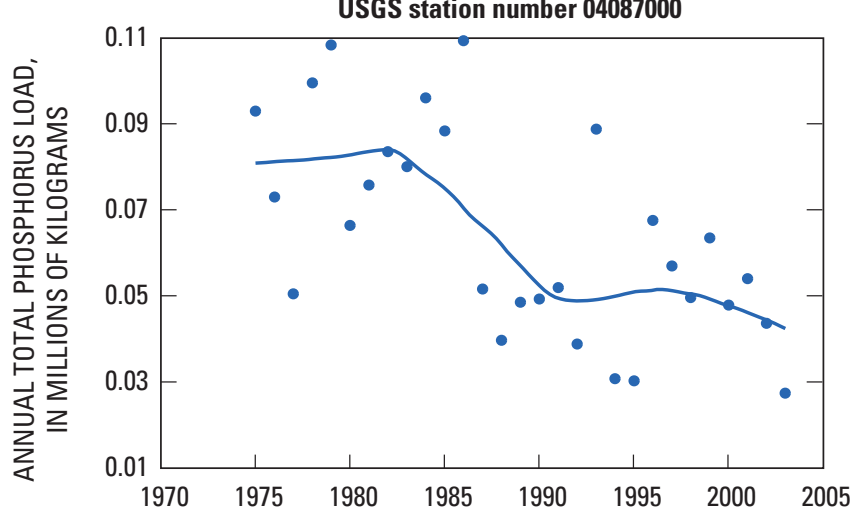

$\boldsymbol{F}$.

Mississippi River at Clinton, lowa

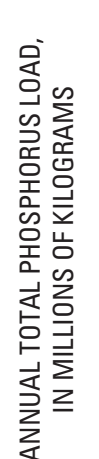

USGS station number 05420500

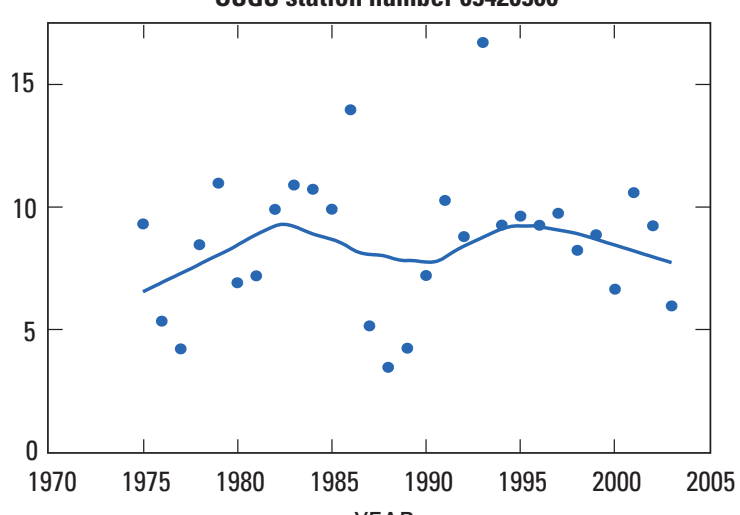

EXPLANATION

YEAR

LOESS smoothing line

- Annual load

Figure 24. Long-term trends in total phosphorus loads from 1975 to 2003 at six selected sites in the study area. 
Table 12. Summary of results for analyses of flow-adjusted trends, overall trends, and trends in loads for dissolved phosphorus (DP, USGS parameter code 00666), 1993 to 2004.

[USGS, U.S. Geological Survey; ID, identification; mg/L, milligram per liter; mg/L/yr, milligram per liter per year; \%/yr, percent per year; kg, kilogram; kg/km², kilogram per square kilometer; kg/yr, kilogram per year; NC, not calculated; sites in bold indicate long-term evaluation sites]

\begin{tabular}{|c|c|c|c|c|c|c|c|c|c|c|c|c|c|c|c|}
\hline \multirow{3}{*}{$\begin{array}{c}\text { USGS } \\
\text { site } \\
\text { number }\end{array}$} & \multirow{3}{*}{$\begin{array}{c}\text { State-ID } \\
\text { number } \\
\text { (figure 1) }\end{array}$} & \multirow{3}{*}{$\begin{array}{c}\text { Water- } \\
\text { quality } \\
\text { model } \\
\text { (table 3) }\end{array}$} & \multicolumn{7}{|c|}{ Concentration } & \multirow{2}{*}{\multicolumn{6}{|c|}{ Annual loads }} \\
\hline & & & \multicolumn{4}{|c|}{ Flow-adjusted trend } & \multicolumn{3}{|c|}{ Overall trend } & & & & & & \\
\hline & & & $\begin{array}{c}\text { Reference } \\
\text { concentration } \\
\text { (mg/L) }\end{array}$ & $\begin{array}{c}\text { Trend } \\
\text { (mg/L/yr) }\end{array}$ & $\begin{array}{l}\text { Trend } \\
(\% / y r)\end{array}$ & p-value & $\begin{array}{c}\text { Trend } \\
\text { (mg/L/yr) }\end{array}$ & $\begin{array}{l}\text { Trend } \\
(\% / y r)\end{array}$ & p-value & $\begin{array}{c}\text { Median } \\
\text { annual load } \\
(\mathrm{kg})\end{array}$ & $\begin{array}{c}\text { Median } \\
\text { yield } \\
\left(\mathbf{k g} / \mathbf{k m}^{2}\right)\end{array}$ & $\begin{array}{c}\text { Reference } \\
\text { load } \\
(\mathrm{kg})\end{array}$ & $\begin{array}{c}\text { Trend } \\
(\mathrm{kg} / \mathrm{yr})\end{array}$ & $\begin{array}{l}\text { Trend } \\
(\% / y r)\end{array}$ & p-value \\
\hline \multicolumn{16}{|c|}{ Western part } \\
\hline 05056100 & ND-1 & 7 & 0.276 & -0.007 & -2.54 & 0.345 & -0.007 & -2.69 & 0.313 & NA & NA & 2,580 & -157 & -6.10 & 0.299 \\
\hline 05056200 & ND-2 & 3 & .283 & .003 & 1.09 & .743 & .004 & 1.40 & .675 & NA & NA & 4,710 & -312 & -6.62 & .226 \\
\hline 05056239 & ND-3 & 3 & .146 & -.003 & -1.75 & .699 & -.005 & -3.63 & .394 & NA & NA & 2,520 & -190 & -7.54 & .160 \\
\hline 05058700 & ND-4 & 8 & .130 & .007 & 5.33 & .375 & .004 & 3.20 & .563 & 60,000 & 9.30 & 29,500 & -58.1 & -.20 & .976 \\
\hline 05082500 & ND-6 & 3 & .097 & -.002 & -2.14 & .453 & -.003 & -2.90 & .291 & 734,000 & 74.5 & 379,000 & $-17,800$ & -4.69 & .136 \\
\hline \multicolumn{16}{|c|}{ Central part } \\
\hline 04063700 & WI-9 & 7 & 0.026 & -0.002 & -7.70 & 0.000 & -0.002 & -7.73 & 0.000 & 860 & 2.39 & 2,170 & -175 & -8.06 & 0.000 \\
\hline 04067500 & WI-10 & 13 & .002 & .001 & .00 & .977 & .001 & .00 & .977 & 30,400 & 2.99 & 4,750 & -1.18 & -.02 & .977 \\
\hline 04085427 & WI-12 & 3 & .077 & -.001 & -1.77 & .605 & -.002 & -2.19 & .498 & 23,200 & 17.0 & 10,100 & -428 & -4.25 & .245 \\
\hline 04087000 & WI-13 & 7 & .043 & -.001 & -1.36 & .402 & -.001 & -1.62 & .317 & 25,300 & 14.0 & 13,900 & -387 & -2.79 & .228 \\
\hline 05287890 & $\mathrm{MN}-14$ & 9 & .056 & .002 & 3.52 & .025 & .001 & .96 & .568 & 5,270 & 23.6 & 1,280 & -65.9 & -5.15 & .121 \\
\hline 05340500 & WI-15 & 5 & .016 & -.001 & -.14 & .980 & .001 & -1.18 & .830 & 116,000 & 7.15 & 62,500 & $-1,340$ & -2.15 & .693 \\
\hline 05369500 & WI-16 & 8 & .039 & -.001 & -3.02 & .142 & -.001 & -3.43 & .091 & 293,000 & 12.6 & 250,000 & $-10,500$ & -4.19 & .068 \\
\hline 05382000 & WI-17 & 8 & .074 & -.001 & -.77 & .419 & -.001 & -1.99 & .035 & 106,000 & 19.7 & 107,000 & $-4,940$ & -4.63 & .002 \\
\hline 05407000 & WI-20 & 3 & .038 & -.002 & -6.35 & .036 & -.003 & -6.78 & .008 & 229,000 & 8.51 & 314,000 & $-22,900$ & -7.30 & .002 \\
\hline 05420500 & IA-21 & 7 & .077 & -.003 & -3.29 & .025 & -.003 & -3.76 & .003 & $4,050,000$ & 18.3 & $4,500,000$ & $-254,000$ & -5.59 & .000 \\
\hline 05427718 & WI-22 & 8 & .097 & -.001 & -.28 & .836 & -.003 & -2.81 & .048 & 3,190 & 16.7 & 2,220 & -104 & -4.69 & .005 \\
\hline 05427948 & WI-23 & 7 & .183 & -.013 & -7.25 & .000 & -.013 & -7.29 & .000 & 1,400 & 31.6 & 520 & -38.3 & -7.38 & .000 \\
\hline 05465500 & IA-25 & 9 & .055 & .001 & 1.04 & .726 & -.002 & -2.97 & .226 & 944,000 & 29.2 & 498,000 & $-31,000$ & -6.23 & .027 \\
\hline 05474000 & IA-26 & 9 & .100 & -.003 & -2.51 & .248 & -.006 & -5.85 & .012 & 324,000 & 29.0 & 205,000 & $-16,000$ & -7.81 & .006 \\
\hline 05500000 & MO-28 & 7 & .053 & -.001 & -.36 & .914 & -.001 & -2.76 & .375 & 52,200 & 32.5 & 4,080 & -376 & -9.23 & .035 \\
\hline 05514500 & MO-29 & 5 & .071 & -.003 & -4.80 & .095 & -.004 & -5.00 & .195 & 73,700 & 31.5 & 7,870 & -418 & -5.31 & .472 \\
\hline 05525500 & IL-30 & 9 & .026 & .001 & .58 & .817 & -.001 & -1.15 & .712 & 75,700 & 65.5 & 3,630 & -135 & -3.71 & .512 \\
\hline 05531500 & IL-31 & 9 & .785 & .025 & 3.19 & .006 & .029 & 3.70 & .018 & 148,000 & 496 & 95,600 & 2,870 & 3.00 & .012 \\
\hline 05532500 & IL-32 & 3 & .490 & .016 & 3.29 & .011 & .025 & 5.03 & .009 & 323,000 & 198 & 255,000 & 6,490 & 2.55 & .060 \\
\hline
\end{tabular}


Table 12. Summary of results for analyses of flow-adjusted trends, overall trends, and trends in loads for dissolved phosphorus (DP, USGS parameter code 00666), 1993 to 2004.-Continued

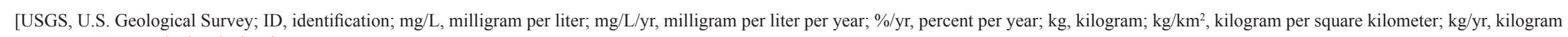
per year; NC, not calculated; sites in bold indicate long-term evaluation sites]

\begin{tabular}{|c|c|c|c|c|c|c|c|c|c|c|c|c|c|c|c|}
\hline \multirow{3}{*}{$\begin{array}{c}\text { USGS } \\
\text { site } \\
\text { number }\end{array}$} & \multirow{3}{*}{$\begin{array}{c}\text { State-ID } \\
\text { number } \\
\text { (figure 1) }\end{array}$} & \multirow{3}{*}{$\begin{array}{c}\text { Water- } \\
\text { quality } \\
\text { model } \\
\text { (table 3) }\end{array}$} & \multicolumn{7}{|c|}{ Concentration } & \multirow{2}{*}{\multicolumn{6}{|c|}{ Annual loads }} \\
\hline & & & \multicolumn{4}{|c|}{ Flow-adjusted trend } & \multicolumn{3}{|c|}{ Overall trend } & & & & & & \\
\hline & & & $\begin{array}{c}\text { Reference } \\
\text { concentration } \\
\text { (mg/L) }\end{array}$ & $\begin{array}{c}\text { Trend } \\
\text { (mg/L/yr) }\end{array}$ & $\begin{array}{l}\text { Trend } \\
\text { (\%/yr) }\end{array}$ & p-value & $\begin{array}{c}\text { Trend } \\
\text { (mg/L/yr) }\end{array}$ & $\begin{array}{l}\text { Trend } \\
(\% / y r)\end{array}$ & p-value & $\begin{array}{c}\text { Median } \\
\text { annual load } \\
(\mathbf{k g})\end{array}$ & $\begin{array}{c}\text { Median } \\
\text { yield } \\
\left(\mathbf{k g} / \mathbf{k m}^{2}\right)\end{array}$ & $\begin{array}{c}\text { Reference } \\
\text { load } \\
(\mathrm{kg})\end{array}$ & $\begin{array}{c}\text { Trend } \\
\text { (kg/yr) }\end{array}$ & $\begin{array}{l}\text { Trend } \\
(\% / y r)\end{array}$ & p-value \\
\hline \multicolumn{16}{|c|}{ Central part-continued } \\
\hline 05540275 & IL-33 & 9 & 0.039 & 0.001 & 0.98 & 0.706 & 0.001 & 0.69 & 0.786 & 411 & 16.0 & 227 & -6.90 & -3.04 & 0.331 \\
\hline 05543500 & IL-34 & 8 & .238 & .018 & 7.59 & .084 & .031 & 12.98 & .009 & $3,970,000$ & 186 & $2,450,000$ & 130,000 & 5.30 & .201 \\
\hline 05586100 & IL-37 & 7 & .158 & .005 & 3.00 & .002 & .008 & 5.11 & .000 & $4,110,000$ & 59.3 & $3,930,000$ & $-97,400$ & -2.48 & .101 \\
\hline \multicolumn{16}{|c|}{ Eastern part } \\
\hline 03085000 & PA-40 & 5 & 0.013 & -0.001 & -1.46 & 0.073 & -0.001 & -1.61 & 0.059 & 110,000 & 5.77 & 89,500 & $\mathrm{NC}$ & -10.14 & 0.091 \\
\hline 03353637 & $\mathrm{IN}-42$ & 9 & .023 & -.002 & -6.65 & .000 & -.002 & -6.78 & .000 & 634 & 14.4 & 202 & -15.0 & -7.37 & .001 \\
\hline 04186500 & $\mathrm{OH}-43$ & 7 & .074 & -.003 & -3.61 & .056 & -.003 & -3.66 & .062 & 26,900 & 31.3 & 5,360 & -210 & -3.87 & .338 \\
\hline 04193500 & OH-44 & 7 & .057 & -.002 & -4.23 & .022 & -.002 & -4.10 & .048 & 486,000 & 29.6 & 108,000 & $-4,100$ & -3.79 & .302 \\
\hline 0422026250 & NY-45 & 9 & .268 & -.012 & -4.34 & .000 & -.014 & -5.18 & .000 & 1,090 & 41.6 & 1,700 & -49.0 & -2.86 & .021 \\
\hline 04232034 & NY-46 & 7 & .008 & -.001 & .00 & .464 & -.001 & .00 & .464 & 345 & 3.40 & 208 & -1.90 & -.92 & .464 \\
\hline 0423204920 & NY-47 & 8 & .022 & -.001 & -4.62 & .002 & -.001 & -4.82 & .001 & 228 & 12.6 & 106 & -6.20 & -5.86 & .004 \\
\hline 0423205025 & NY-48 & 9 & .018 & -.001 & -2.21 & .027 & -.001 & -2.41 & .015 & 2,440 & 6.59 & 1,740 & -69.0 & -3.96 & .017 \\
\hline
\end{tabular}




\section{Trends in Dissolved Phosphorus Concentrations}

The FA trends in DP concentrations from 1993 to 2004 showed mixed regional tendencies; however, DP concentrations consistently decreased at all of the sites in the eastern part of the study area (table 12; fig. 25A). Of the 35 sites that had sufficient streamflow and DP concentration data for analysis, 23 sites had downward trends in concentrations. Twelve of these sites had significant downward trends $(\mathrm{p}<0.10)$. Seven sites in the eastern part of the study area had downward trends. Five sites, all in the central part of the study area, had significant upward trends $(\mathrm{p}<0.10)$. Two sites had almost no FA trends.

When the OA trends in DP concentrations from 1993 to 2004 were examined, spatial trends followed the same general decreasing concentration pattern in the eastern areas with mixed tendencies in the central and western parts of the study area. Several differences between the FA and OA trend analyses occurred at specific sites in the central area, where many more sites had significantly downward OA trends than downward FA trends. These differences in the results of the FA and $\mathrm{OA}$ trend analyses are attributable to the significant trends in streamflow. Of the 35 sites that had sufficient streamflow and DP data for analysis (table 12; fig. 25B), 25 sites had downward trends, 8 sites had upward trends, and 2 sites had almost no trend in concentrations. Of these sites, 15 sites had significant downward trends, and 4 sites (all in Illinois) had significant upward trends $(\mathrm{p}<0.10)$.

\section{Trends in Dissolved Phosphorus Loads}

From 1993 to 2004, dissolved phosphorus loads at 32 of the 35 sites that had sufficient data for analysis indicated a tendency toward decreasing loads (table 12; fig. 25C); trends at 15 of these sites were significant $(p<0.10)$. Two of the three sites, all located in northern Illinois, with upward trends in loads had significant upward trends.

\section{Total Suspended Materials}

\section{General Patterns in Concentrations and Yields of Total Suspended Materials}

Median midmonthly total SMAT concentrations in the study area ranged from 0.7 to $5,240 \mathrm{mg} / \mathrm{L}$, based on data for all of the sites from 1970 to 2004 (fig. 26A). The overall median and mean SMAT concentrations were 24.0 and $112 \mathrm{mg} / \mathrm{L}$, respectively. The highest concentrations were in the western, southwestern, and south-central parts of the study area. The lowest concentrations were mostly in northern areas of Wisconsin and Michigan and in the northeastern part of the study area. The highest concentrations were in areas with intensive row-crop agriculture, and the lowest concentrations were in forested areas. Median midmonthly SMAT concentrations ranged from 4.0 to $424 \mathrm{mg} / \mathrm{L}$ at the 42 trend sites that had sufficient data for analysis, based on data from 1993 to 2004. The mean and median values of the median SMAT concentrations at these sites were 59.1 and $37.5 \mathrm{mg} / \mathrm{L}$, respectively. The distribution in concentrations of these trend sites was consistent with that shown in fig. 26A.

Median annual SMAT yields from 1970 to 2004 ranged from 22.0 to $3,370,000 \mathrm{~kg} / \mathrm{km}^{2}$. The overall mean and median yields based on all of the data in the study area from 1970 to 2004 were 85,100 and 35,400 and $\mathrm{kg} / \mathrm{km}^{2}$, respectively. The highest yields were from basins throughout the southern one-half of the study area, and the lowest yields were from basins throughout the northern one-half of the study area (fig. 26B). Similar to TP and TN, the major difference in the distributions in SMAT between concentrations and yields was in the northwestern part of the study area, which had high concentrations but low yields, primarily because of low mean annual runoff (fig. 3). Median annual SMAT yields at trend sites, based on data from 1993 to 2004, ranged from 188 to $939,000 \mathrm{~kg} / \mathrm{km}^{2}$ (table 13). The distribution in yields was consistent with that in fig. 26B. The mean and median yields based only on data from the trend sites were 60,100 and $25,300 \mathrm{~kg} / \mathrm{km}^{2}$, respectively.

\section{Trends in Total Suspended-Material Concentrations}

The FA trends in SMAT concentrations from 1993 to 2004 showed distinct spatial patterns of tendencies toward increasing concentrations in Illinois, and tendencies toward decreasing concentrations throughout most of Wisconsin, Iowa, and the eastern part of the study area (fig. 27A). Of the 42 sites that had sufficient streamflow and SMAT concentration data for analysis (table 13), 25 sites had downward trends, and 17 sites had upward trends in concentrations. Of these sites, 12 sites had significant downward trends, and 5 sites had significant upward trends $(\mathrm{p}<0.10)$.

The spatial pattern in the OA trends in SMAT concentrations generally was the same as that for the FA trends (fig. 27B); however, several of the sites with nonsignificant downward trends, especially in Iowa, had significant downward OA trends $(\mathrm{p}<0.10)$. Of the 42 sites that had sufficient streamflow and SMAT concentration data for analysis (table 13), 30 sites had downward trends, and 12 sites had upward trends in concentrations. Of these sites, 18 sites had significant downward trends, and 5 sites had significant upward trends. The sites with significant increases in concentrations were in Illinois and North Dakota. 


\section{A. Flow-adjusted trend in concentrations}

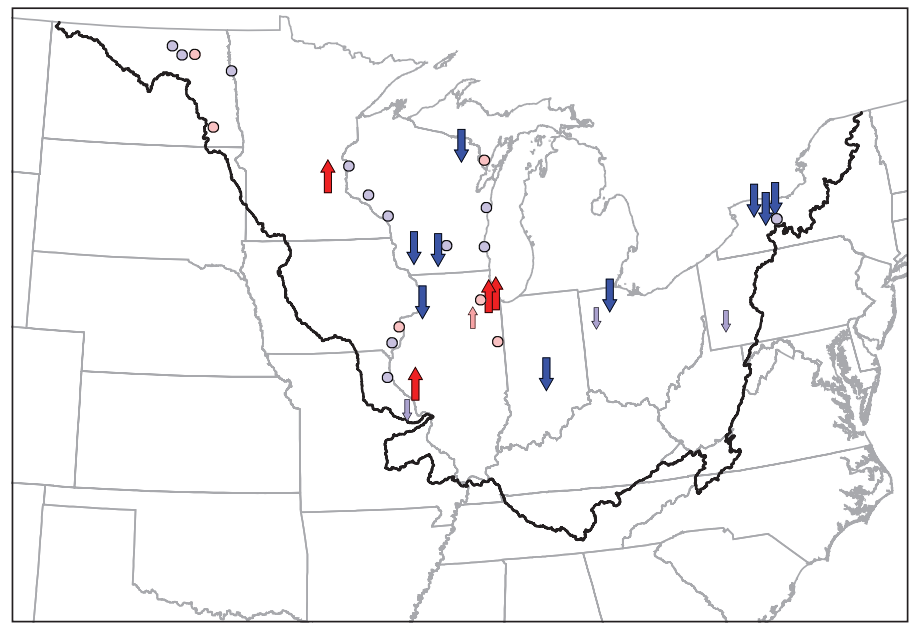

\section{B. Overall trend in concentrations}

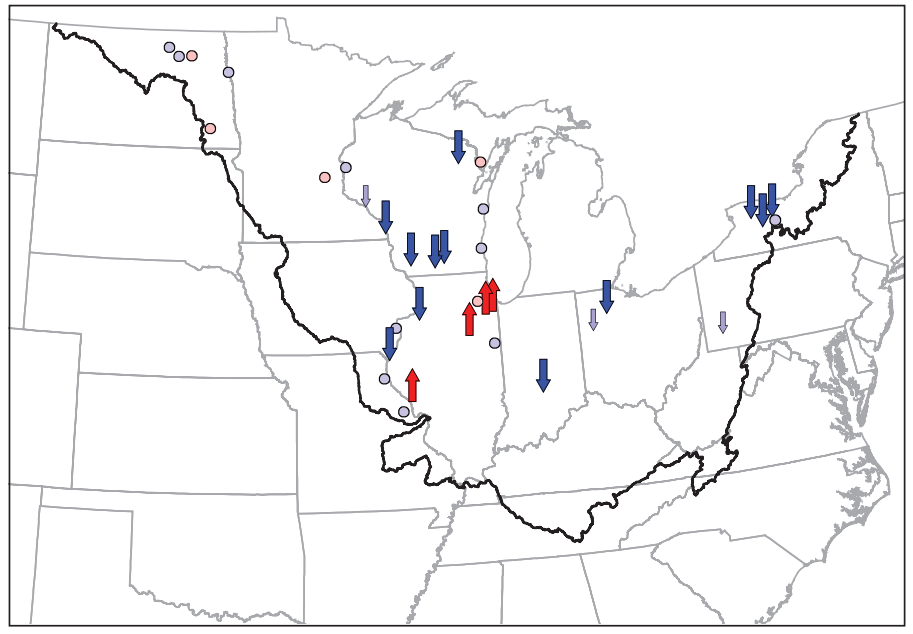

DISSOLVED

PHOSPHORUS

\begin{tabular}{|l|}
\hline \multicolumn{1}{|c|}{ EXPLANATION } \\
Trends \\
$\hat{i}$ Upward $(\mathrm{p}<0.05)$ \\
$\Uparrow$ Upward $(0.05 \leq \mathrm{p}<0.1)$ \\
$\circ$ Upward $(\mathrm{p} \geq 0.1)$ \\
$\circ$ Downward $(\mathrm{p} \geq 0.1)$ \\
$\Downarrow$ Downward $(0.05 \leq \mathrm{p}<0.1)$ \\
$\Downarrow$ Downward $(\mathrm{p}<0.05)$ \\
\hline
\end{tabular}

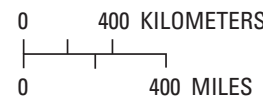

\section{Trend in annual loads}

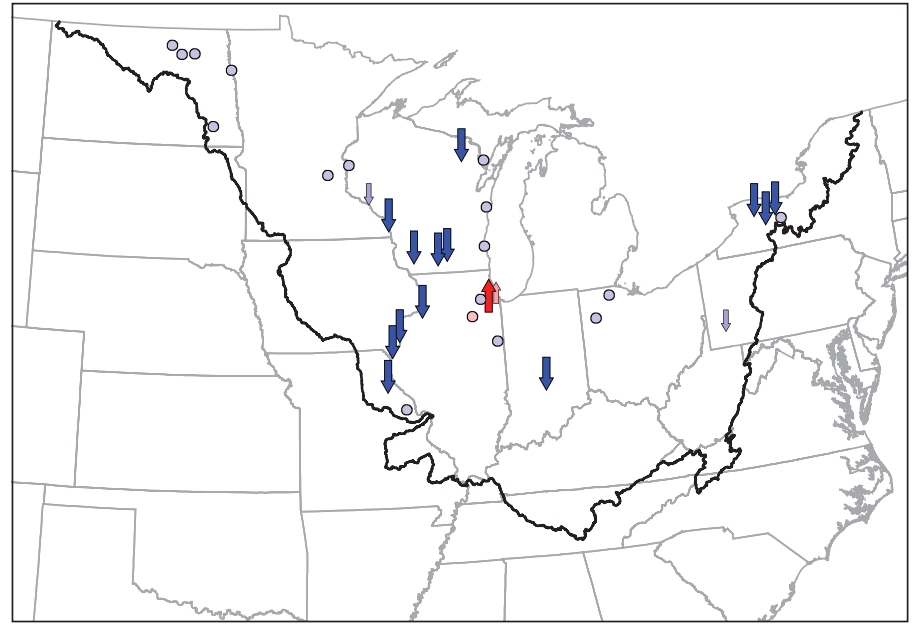

Figure 25. Trends in dissolved phosphorus from 1993 to 2004 for $\boldsymbol{A}$, flow-adjusted concentrations, $\boldsymbol{B}$, overall concentrations, and $\boldsymbol{C}$, annual loads throughout the study area. 


\section{A. Median total suspended-material concentrations}

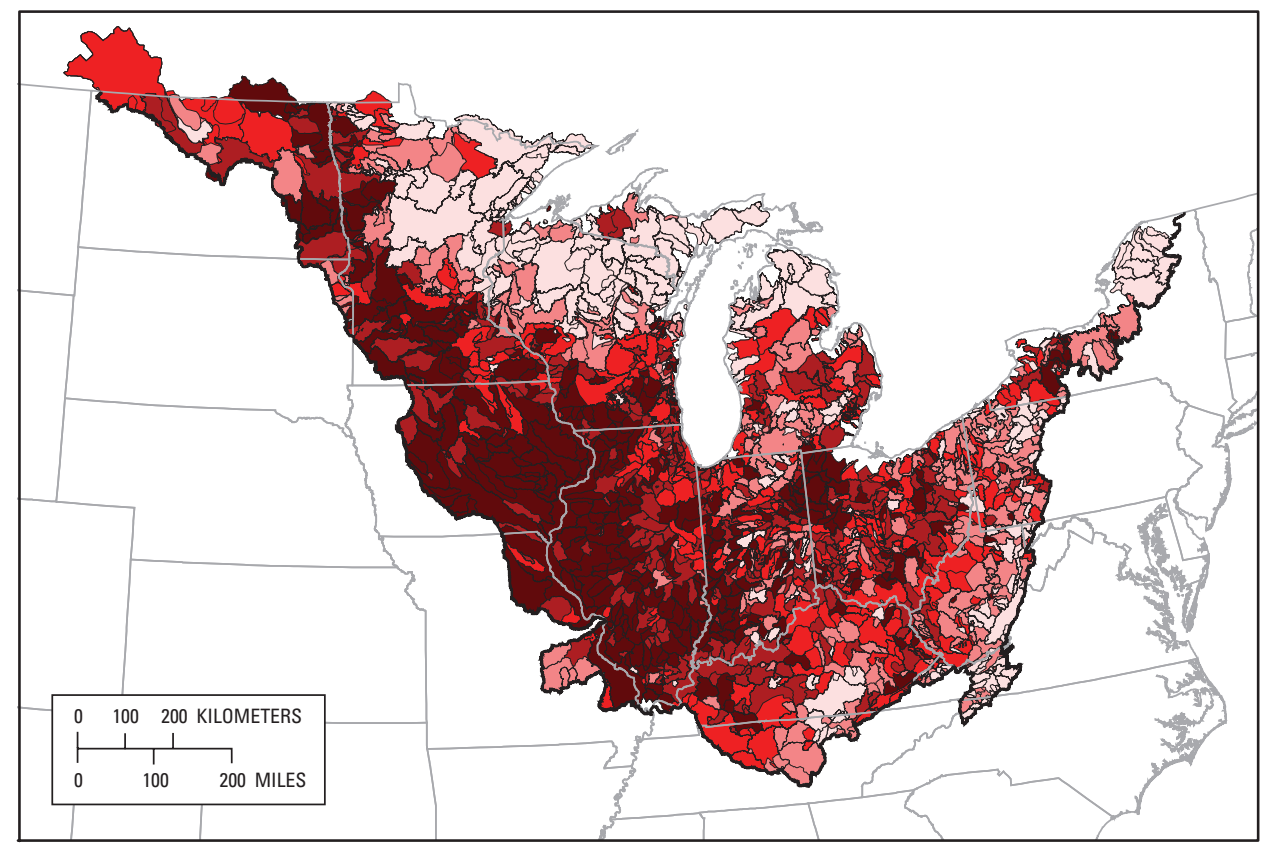

EXPLANATION

Median concentration, in milligrams per liter

$\square 0.7-7.0$

$\square 7.1-13$

$14-23$

$24-41$

$42-5,240$

- Study area

- State boundary

- Basin boundary

\section{B. Median annual total suspended-material yields}

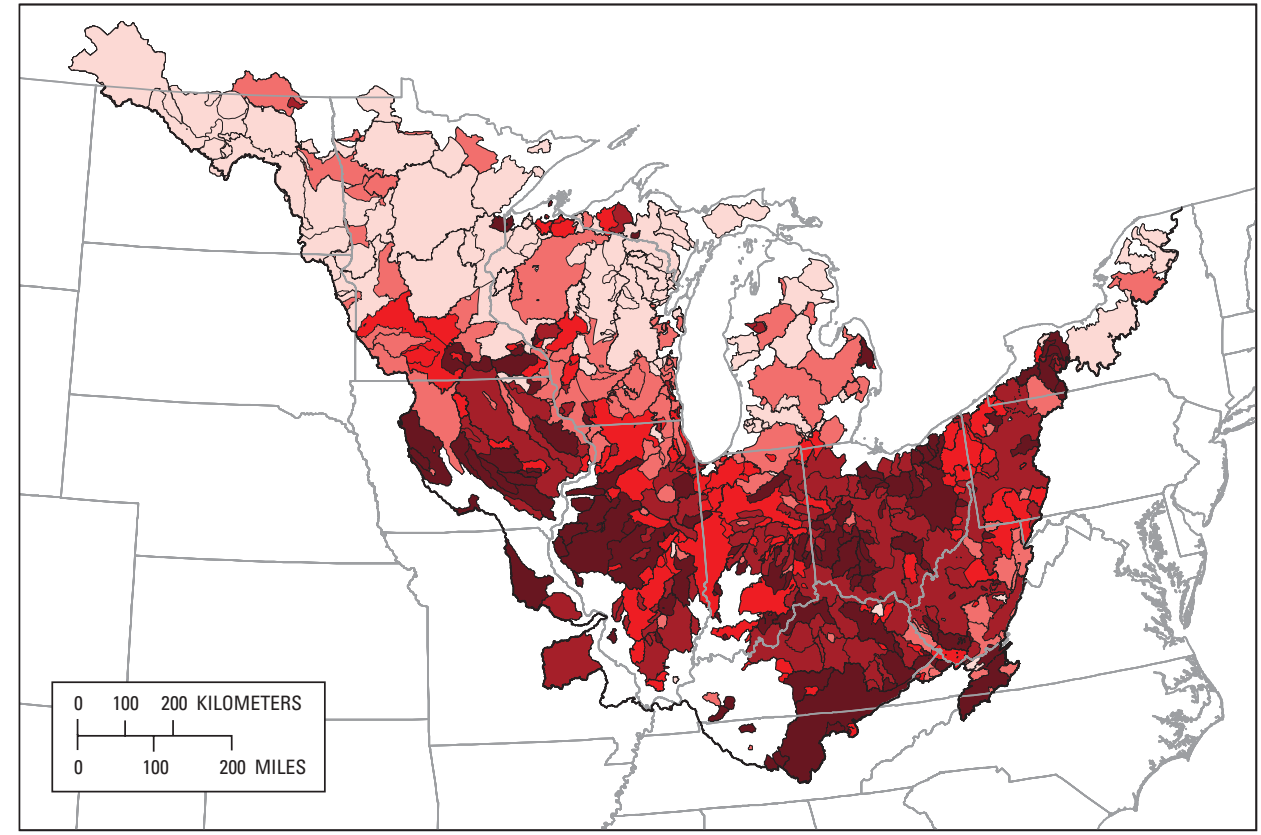

EXPLANATION

Median annual yield, in kilograms per square kilometer

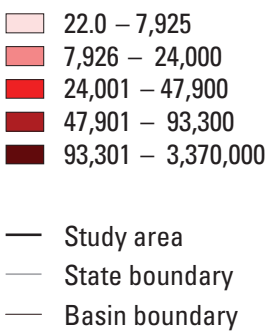

Figure 26. Spatial patterns from 1970 to 2004 in $\boldsymbol{A}$, median total suspended-material concentrations and $\boldsymbol{B}$, median annual total suspended-material yields throughout the study area. 


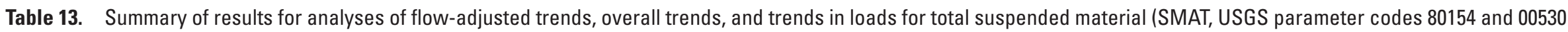
combined), 1993 to 2004.

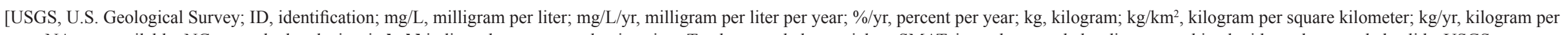

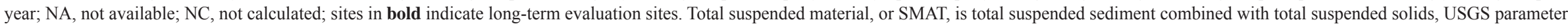
codes 80154 and 00530 , respectively.]

\begin{tabular}{|c|c|c|c|c|c|c|c|c|c|c|c|c|c|c|c|}
\hline \multirow{3}{*}{$\begin{array}{l}\text { USGS } \\
\text { site } \\
\text { number }\end{array}$} & \multirow{3}{*}{$\begin{array}{c}\text { State-ID } \\
\text { number } \\
\text { (figure 1) }\end{array}$} & \multirow{3}{*}{$\begin{array}{c}\text { Water- } \\
\text { quality } \\
\text { model } \\
\text { (table 3) }\end{array}$} & \multicolumn{7}{|c|}{ Concentration } & \multirow{2}{*}{\multicolumn{6}{|c|}{ Annual loads }} \\
\hline & & & \multicolumn{4}{|c|}{ Flow-adjusted trend } & \multicolumn{3}{|c|}{ Overall trend } & & & & & & \\
\hline & & & $\begin{array}{c}\text { Reference } \\
\text { concentration } \\
\text { (mg/L) }\end{array}$ & $\begin{array}{c}\text { Trend } \\
\text { (mg/L/yr) }\end{array}$ & $\begin{array}{l}\text { Trend } \\
(\% / y r)\end{array}$ & p-value & $\begin{array}{c}\text { Trend } \\
\text { (mg/L/yr) }\end{array}$ & $\begin{array}{l}\text { Trend } \\
(\% / y r)\end{array}$ & p-value & $\begin{array}{c}\text { Median } \\
\text { annual } \\
\text { load } \\
(\mathbf{k g})\end{array}$ & $\begin{array}{l}\text { Median } \\
\text { yield } \\
\left(\mathbf{k g} / \mathbf{k m}^{2}\right)\end{array}$ & $\begin{array}{c}\text { Reference } \\
\text { load } \\
(\mathrm{kg})\end{array}$ & $\begin{array}{l}\text { Trend } \\
(\mathrm{kg} / \mathrm{yr})\end{array}$ & $\begin{array}{l}\text { Trend } \\
(\% / y r)\end{array}$ & p-value \\
\hline \multicolumn{16}{|c|}{ Western part } \\
\hline 05082500 & ND-6 & 5 & 70.3 & 7.148 & 10.17 & 0.675 & 2.750 & 3.91 & 0.857 & NA & NA & $267,000,000$ & $1,280,000$ & 0.48 & 0.982 \\
\hline 05114000 & ND-7 & 9 & 5.0 & .187 & 3.75 & .223 & .427 & 8.56 & .077 & $1,480,000$ & 188 & 26,200 & NC & 94.14 & .052 \\
\hline 05120000 & ND-8 & 9 & 5.6 & .092 & 1.65 & .593 & .172 & 3.07 & .420 & $2,770,000$ & 243 & 207,000 & $\mathrm{NC}$ & 10.25 & .410 \\
\hline \multicolumn{16}{|c|}{ Central part } \\
\hline 04063700 & WI-9 & 7 & 3.8 & 0.208 & 5.48 & 0.132 & 0.156 & 4.12 & 0.221 & 956,000 & 2,660 & 316,000 & $-1,100$ & -0.33 & 0.915 \\
\hline 04067500 & WI-10 & 8 & 5.0 & -.149 & -2.97 & .164 & -.150 & -2.98 & .182 & $15,800,000$ & 1,560 & $12,000,000$ & $-360,000$ & -3.01 & .266 \\
\hline 04073468 & WI-11 & 9 & 21.9 & .414 & 1.89 & .081 & .369 & 1.68 & .128 & 897,000 & 6,470 & 586,000 & $-6,200$ & -1.07 & .708 \\
\hline 04085427 & WI-12 & 3 & 33.7 & -2.134 & -6.32 & .080 & -2.085 & -6.18 & .078 & $5,100,000$ & 3,740 & $4,460,000$ & $-310,000$ & -7.00 & .032 \\
\hline 04087000 & WI-13 & 7 & 30.3 & .205 & .68 & .667 & .057 & .19 & .907 & $22,400,000$ & 12,400 & $9,790,000$ & $-130,000$ & -1.28 & .619 \\
\hline 05287890 & $\mathrm{MN}-14$ & 7 & 6.9 & .035 & .50 & .812 & -.172 & -2.49 & .240 & $1,010,000$ & 4,540 & 156,000 & $-9,900$ & -6.39 & .046 \\
\hline 05340500 & WI-15 & 8 & 5.3 & .028 & .53 & .901 & -.020 & -.38 & .927 & $56,400,000$ & 3,490 & $19,400,000$ & $-280,000$ & -1.46 & .731 \\
\hline 05369500 & WI-16 & 7 & 8.8 & -.256 & -2.91 & .072 & -.285 & -3.24 & .042 & $90,700,000$ & 3,880 & $57,000,000$ & $-2,300,000$ & -4.03 & .038 \\
\hline 05382000 & WI-17 & 9 & 26.3 & -1.221 & -4.64 & .001 & -1.396 & -5.31 & .000 & $41,000,000$ & 7,600 & $38,100,000$ & $-2,500,000$ & -6.63 & .000 \\
\hline 05389400 & IA-18 & 9 & 83.9 & -.074 & -.09 & .977 & -1.581 & -1.88 & .410 & $1,100,000$ & 12,500 & $2,080,000$ & $-110,000$ & -5.35 & .007 \\
\hline 05389500 & IA-19 & 3 & 36.2 & -1.051 & -2.90 & .179 & -1.311 & -3.62 & .063 & $2,140,000,000$ & 12,200 & $1,510,000,000$ & $-82,000,000$ & -5.42 & .004 \\
\hline 05407000 & WI-20 & 7 & 24.5 & -1.067 & -4.35 & .005 & -1.110 & -4.53 & .001 & $175,000,000$ & 6,490 & $204,000,000$ & $-12,000,000$ & -5.63 & .000 \\
\hline 05420500 & IA-21 & 8 & 54.3 & -1.534 & -2.83 & .109 & -2.478 & -4.57 & .003 & $3,950,000,000$ & 17,800 & $3,190,000,000$ & $-190,000,000$ & -6.10 & .000 \\
\hline 05427718 & WI-22 & 9 & 40.4 & -1.257 & -3.11 & .000 & -1.942 & -4.80 & .000 & $2,210,000$ & 11,600 & 929,000 & $-56,000$ & -6.00 & .000 \\
\hline 05427948 & WI-23 & 8 & 33.7 & -1.006 & -2.98 & .000 & -1.046 & -3.10 & .000 & $1,410,000$ & 31,900 & 95,800 & $-3,300$ & -3.43 & .024 \\
\hline 054310157 & WI-24 & 8 & 48.1 & -1.422 & -2.95 & .007 & -1.410 & -2.93 & .010 & 447,000 & 39,800 & 59,400 & $-1,600$ & -2.76 & .280 \\
\hline 05465500 & IA-25 & 8 & 181.0 & -2.893 & -1.60 & .401 & -9.416 & -5.20 & .008 & $1,860,000,000$ & 57,300 & $1,640,000,000$ & $-120,000,000$ & -7.21 & .004 \\
\hline 05474000 & IA-26 & 7 & 207.0 & -4.453 & -2.15 & .267 & -12.022 & -5.81 & .007 & $1,420,000,000$ & 127,000 & $417,000,000$ & $-33,000,000$ & -7.80 & .006 \\
\hline 05481650 & IA-27 & 3 & 52.9 & -1.361 & -2.57 & .232 & -2.444 & -4.62 & .007 & $213,000,000$ & 14,100 & $166,000,000$ & $-13,000,000$ & -7.83 & .000 \\
\hline 05500000 & MO-28 & 8 & 28.8 & -.893 & -3.10 & .368 & -1.794 & -6.22 & .030 & $388,000,000$ & 242,000 & $3,680,000$ & $-290,000$ & -7.96 & .012 \\
\hline
\end{tabular}


Table 13. Summary of results for analyses of flow-adjusted trends, overall trends, and trends in loads for total suspended material (SMAT, USGS parameter codes 80154 and 00530 combined), 1993 to 2004.-Continued

[USGS, U.S. Geological Survey; ID, identification; mg/L, milligram per liter; mg/L/yr, milligram per liter per year; \%/yr, percent per year; kg, kilogram; kg/km², kilogram per square kilometer; kg/yr, kilogram per year; NA, not available; NC, not calculated; sites in bold indicate long-term evaluation sites. Total suspended material, or SMAT, is total suspended sediment combined with total suspended solids, USGS parameter codes 80154 and 00530 , respectively.]

\begin{tabular}{|c|c|c|c|c|c|c|c|c|c|c|c|c|c|c|c|}
\hline \multirow{3}{*}{$\begin{array}{c}\text { USGS } \\
\text { site } \\
\text { number }\end{array}$} & \multirow{3}{*}{$\begin{array}{c}\text { State-ID } \\
\text { number } \\
\text { (figure 1) }\end{array}$} & \multirow{3}{*}{$\begin{array}{c}\text { Water- } \\
\text { quality } \\
\text { model } \\
\text { (table 3) }\end{array}$} & \multicolumn{7}{|c|}{ Concentration } & \multirow{2}{*}{\multicolumn{6}{|c|}{ Annual loads }} \\
\hline & & & \multicolumn{4}{|c|}{ Flow-adjusted trend } & \multicolumn{3}{|c|}{ Overall trend } & & & & & & \\
\hline & & & $\begin{array}{c}\text { Reference } \\
\text { concentration } \\
\text { (mg/L) }\end{array}$ & $\begin{array}{c}\text { Trend } \\
\text { (mg/L/yr) }\end{array}$ & $\begin{array}{l}\text { Trend } \\
(\% / y r)\end{array}$ & p-value & $\begin{array}{c}\text { Trend } \\
\text { (mg/L/yr) }\end{array}$ & $\begin{array}{l}\text { Trend } \\
(\% / y r)\end{array}$ & p-value & $\begin{array}{c}\text { Median } \\
\text { annual } \\
\text { load } \\
(\mathrm{kg})\end{array}$ & $\begin{array}{l}\text { Median } \\
\text { yield } \\
\left(\mathrm{kg} / \mathrm{km}^{2}\right)\end{array}$ & $\begin{array}{c}\text { Reference } \\
\text { load } \\
(\mathbf{k g})\end{array}$ & $\begin{array}{c}\text { Trend } \\
(\mathrm{kg} / \mathrm{yr})\end{array}$ & $\begin{array}{l}\text { Trend } \\
(\% / y r)\end{array}$ & p-value \\
\hline \multicolumn{16}{|c|}{ Central part-continued } \\
\hline 05525500 & IL-30 & 9 & 17.4 & 6.025 & 34.60 & 0.000 & 5.417 & 31.11 & 0.000 & $100,000,000$ & 87,000 & $2,510,000$ & 438,000 & 17.49 & 0.111 \\
\hline 05531500 & IL-31 & 9 & 16.6 & 6.202 & 37.39 & .000 & 6.071 & 36.60 & .000 & $22,300,000$ & 74,800 & $2,010,000$ & $\mathrm{NC}$ & 34.07 & .000 \\
\hline 05532500 & IL-32 & 9 & 16.4 & 5.681 & 34.62 & .000 & 4.932 & 30.06 & .000 & $83,500,000$ & 51,100 & $8,450,000$ & $\mathrm{NC}$ & 23.02 & .001 \\
\hline 05540275 & IL-33 & 7 & 10.5 & .328 & 3.13 & .260 & .063 & .61 & .827 & 328,000 & 12,800 & 59,700 & $-1,800$ & -3.09 & .422 \\
\hline 05543500 & IL-34 & 8 & 31.0 & .783 & 2.52 & .320 & -.199 & -.64 & .785 & $542,000,000$ & 25,300 & $296,000,000$ & $-13,000,000$ & -4.34 & .081 \\
\hline 05552500 & IL-35 & 7 & 37.9 & .214 & .56 & .872 & -.960 & -2.53 & .406 & $164,000,000$ & 24,900 & $71,800,000$ & $-3,800,000$ & -5.29 & .087 \\
\hline 05570000 & IL-36 & 7 & 85.0 & 10.015 & 11.78 & .250 & 2.602 & 3.06 & .696 & $489,000,000$ & 115,000 & $80,600,000$ & $-4,000,000$ & -4.91 & .419 \\
\hline 05586100 & IL-37 & 9 & 81.5 & 12.415 & 15.23 & .000 & 8.016 & 9.83 & .000 & $3,490,000,000$ & 50,300 & $2,020,000,000$ & $-7,300,000$ & -.36 & .908 \\
\hline 07014500 & MO-38 & 7 & 6.5 & .016 & .25 & .959 & -.307 & -4.71 & .159 & $46,900,000$ & 12,300 & $7,280,000$ & $-510,000$ & -6.95 & .015 \\
\hline 07018100 & MO-39 & 5 & 4.1 & -.120 & -2.96 & .558 & -.190 & -4.68 & .248 & $52,200,000$ & 27,400 & $1,890,000$ & $-130,000$ & -6.79 & .041 \\
\hline \multicolumn{16}{|c|}{ Eastern part } \\
\hline 03085000 & PA-40 & 9 & 10.7 & -0.655 & -6.14 & 0.005 & -0.601 & -5.63 & 0.022 & $609,000,000$ & 32,000 & $70,700,000$ & $-3,400,000$ & -4.75 & 0.173 \\
\hline 03353637 & $\mathrm{IN}-42$ & 8 & 21.2 & -.371 & -1.75 & .361 & -.581 & -2.74 & .206 & $3,780,000$ & 85,800 & 178,000 & $-8,300$ & -4.67 & .236 \\
\hline 04186500 & $\mathrm{OH}-43$ & 7 & 47.4 & -3.272 & -6.90 & .001 & -3.301 & -6.96 & .002 & $32,500,000$ & 37,700 & $3,550,000$ & $-250,000$ & -7.10 & .081 \\
\hline 04193500 & OH-44 & 9 & 32.9 & -1.322 & -4.02 & .008 & -1.268 & -3.86 & .043 & $1,040,000,000$ & 63,600 & $61,900,000$ & $-2,200,000$ & -3.54 & .347 \\
\hline 0422026250 & NY-45 & 7 & 91.4 & -5.705 & -6.24 & .000 & -5.109 & -5.59 & .000 & $1,600,000$ & 61,100 & 572,000 & $-20,000$ & -3.56 & .212 \\
\hline 04232034 & NY-46 & 7 & 132.1 & -7.685 & -5.82 & .000 & -7.818 & -5.92 & .000 & $6,020,000$ & 59,300 & $3,470,000$ & $-220,000$ & -6.20 & .000 \\
\hline 0423204920 & NY-47 & 7 & 72.4 & -.850 & -1.17 & .603 & -1.178 & -1.63 & .472 & 978,000 & 54,200 & 341,000 & $-11,000$ & -3.30 & .252 \\
\hline 0423205025 & NY-48 & 9 & 45.6 & -.585 & -1.28 & .429 & -.791 & -1.73 & .285 & $11,900,000$ & 32,000 & $4,380,000$ & $-150,000$ & -3.43 & .111 \\
\hline 04237946 & NY-49 & 9 & 984.6 & -13.718 & -1.39 & .288 & -14.079 & -1.43 & .280 & 778,000 & 939,000 & 608,000 & $-7,100$ & -1.17 & .518 \\
\hline
\end{tabular}




\section{A. Flow-adjusted trend in concentrations}

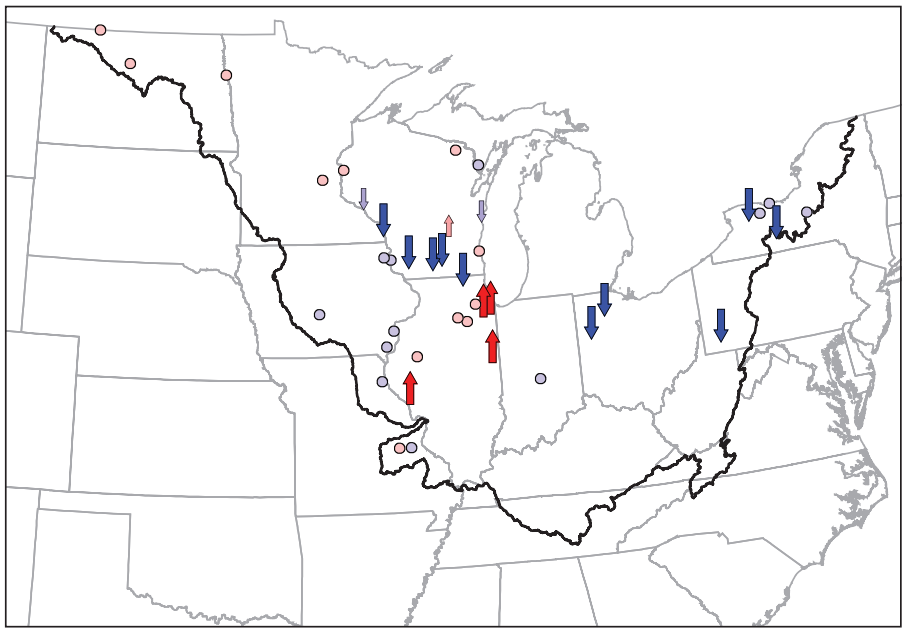

\section{B. Overall trend in concentrations}

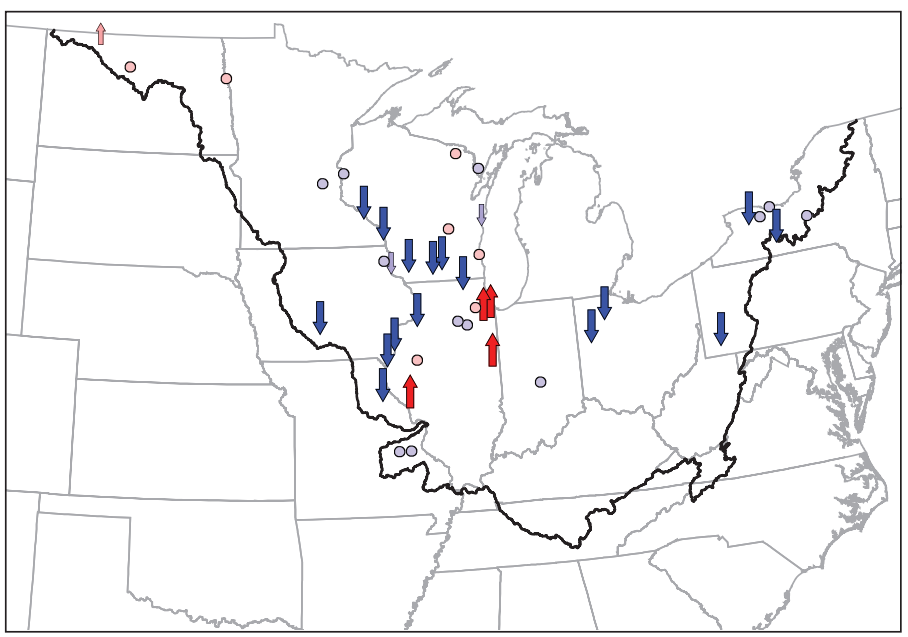

\section{Trend in annual loads}

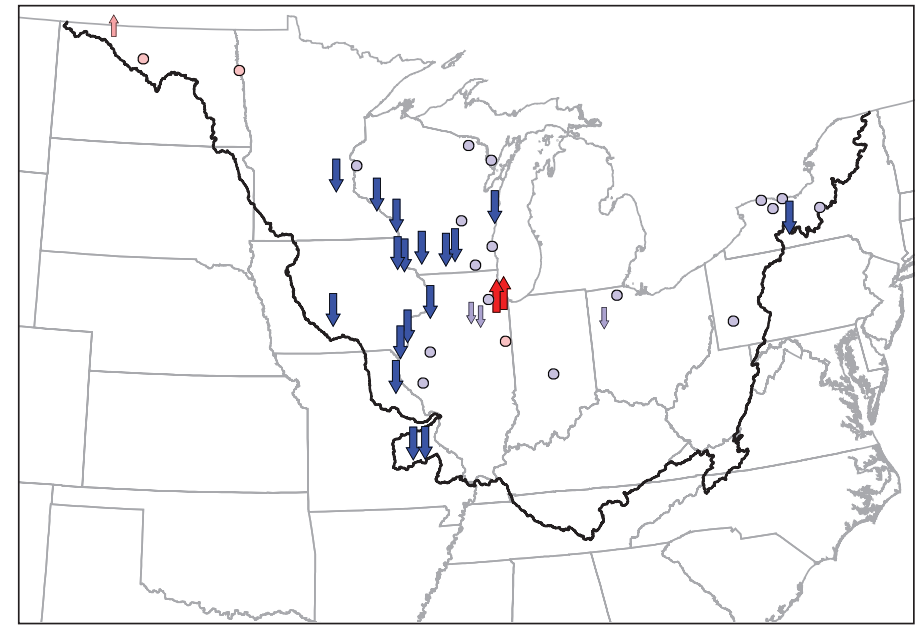

\section{SUSPENDED MATERIAL}

EXPLANATION

Trends

1. Upward (p < 0.05)

if Upward $(0.05 \leq \mathrm{p}<0.1)$

- $\operatorname{Upward}(\mathrm{p} \geq 0.1)$

- Downward ( $\mathrm{p} \geq 0.1$ )

ป Downward $(0.05 \leq \mathrm{p}<0.1)$

$\checkmark$ Downward $(\mathrm{p}<0.05)$

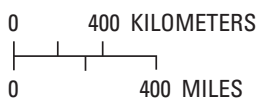

Figure 27. Trends in total suspended materials from 1993 to 2004 for $\boldsymbol{A}$, flow-adjusted concentrations, $\boldsymbol{B}$, overall concentrations, and $\boldsymbol{C}$, annual loads throughout the study area. 
To place the 1993-2004 trends in SMAT concentrations into a longer term context, FACs were computed from 1975 to 2004 for the six sites that had sufficient data and examined for trends with QWTREND (table 14; fig. 28). Only one site, the Milwaukee River (04087000), had an upward trend over the entire period from 1975 through 2004. The Chippewa River had an upward trend from 1975 through 1981, a downward trend from 1982 through 2001, and no trend from 2002 through 2004. The Souris (05114000) and Maumee (05420500) Rivers had no trend through the early part of the period and downward trends in the later part, beginning in 1996. Myers and others (2000) reported a relatively small, but significant, downward trend in FACs from 1970 to 1998. The Iowa River (05465500) had a downward trend from 1982 through 2004, and the Mississippi River (05420500) showed downward trends throughout the period from 1975 though 2004. Three sites $(05465500,04193500$, and 05420500$)$ had FACs in 2004 that were less than one-half of the FACs in 1975 (table 14).

\section{Trends in Total Suspended-Material Loads}

From 1993 to 2004, SMAT loads indicated a tendency toward decreasing loads at 36 sites and a tendency toward increasing loads at 6 sites (table 13; fig. 27C). Downward trends in loads at 20 of the sites, throughout most of the study area, were significant, and upward trends at 3 sites in northern Illinois and North Dakota were significant $(\mathrm{p}<0.10)$. Once again the pattern in the trends in loads resembles that for streamflow (fig. 12).

Annual SMAT loads at the six long-term sites from 1975 to 2003 can be used to put the short-term trends in loads into a longer term context (fig. 29). The long-term changes at all six sites resembled the long-term trend in streamflow (fig. 12), which again indicates the importance of changes in streamflow in driving the trends in loads. A combination of total suspended sediment (SS) and total suspended solid data was used to estimate changes in the long-term loads at all of the sites except the Iowa and Maumee Rivers, which were estimated on the basis of only SS data. This combination of data from two different types of analysis could in itself induce long-term trends in the loads; however, for these sites, the major changes appear to be associated with changes in streamflow.

The SMAT loads at the Souris River, N.Dak., decreased after a very high streamflow period (fig. 13) in the mid-1970s until approximately 1987 , when loads remained relatively constant until 2003; however, very few SMAT samples were collected during the early years of the record, so the apparent large downward trend in loads may be partially attributable to sampling bias. For example, only two suspended-material samples were collected in 1975, and only five samples were collected in 1976 - the two highest loading years (fig. 29).

Loads at the Chippewa River at Durand, Wisc., increased from 1975 to 1982 and then decreased at a fairly constant rate until 2003. Loads at the Milwaukee, Iowa, and Mississippi Rivers generally increased from 1975 to about 1982, then generally decreased until about 1990, and then remained approximately constant during a period of irregular wet or dry years until 2003. It is probable that both streamflow and the associated transport of suspended materials in these rivers were affected by the presence of the many dams upstream from the sampling sites. The SMAT loads at the Maumee River at Waterville, Ohio, decreased from 1975 to about 1987, and then generally increased through 1994, then decreased again during a period of wet and dry years until 2003.

Table 14. Summary of flow-adjusted trends in total suspended-material concentrations estimated by OWTREND for longterm evaluation sites, 1975 to 2004.

[USGS, U.S. Geological Survey; mg/L, milligram per liter. Total suspended material, or SMAT, is total suspended sediment combined with total suspended solids, USGS parameter codes 80154 and 00530, respectively]

\begin{tabular}{|c|c|c|}
\hline USGS site number & Trend period & Description of flow-adjusted concentration \\
\hline \multirow[t]{2}{*}{05114000} & January 1975-December 1995 & Constant value of $13.3 \mathrm{mg} / \mathrm{L}$ \\
\hline & January 1996-December 2004 & Downward trend from 13.3 to $7.0 \mathrm{mg} / \mathrm{L}$ \\
\hline \multirow[t]{3}{*}{05369500} & January 1975-December 1981 & Upward trend from 8.3 to $22.5 \mathrm{mg} / \mathrm{L}$ \\
\hline & January 1982-December 2001 & Downward trend from 22.5 to $7.1 \mathrm{mg} / \mathrm{L}$ \\
\hline & January 2002-December 2004 & Constant value of $7.1 \mathrm{mg} / \mathrm{L}$ \\
\hline \multirow[t]{2}{*}{05465500} & February 1978-December 1981 & Constant value of $149 \mathrm{mg} / \mathrm{L}$ \\
\hline & January 1982-December 2004 & Downward trend from 149 to $67 \mathrm{mg} / \mathrm{L}$ \\
\hline 04087000 & January 1975-December 2004 & Upward trend from 19.8 to $28.9 \mathrm{mg} / \mathrm{L}$ \\
\hline \multirow[t]{2}{*}{04193500} & January 1975-December 1995 & Constant value of $57.0 \mathrm{mg} / \mathrm{L}$ \\
\hline & January 1996-December 2004 & Downward trend from 57.0 to $21.7 \mathrm{mg} / \mathrm{L}$ \\
\hline 05420500 & January 1975-December 2004 & Downward trend from 56.1 to $24.3 \mathrm{mg} / \mathrm{L}$ \\
\hline
\end{tabular}




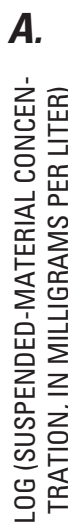

Souris River near Sherwood, North Dakota USGS station number 05114000

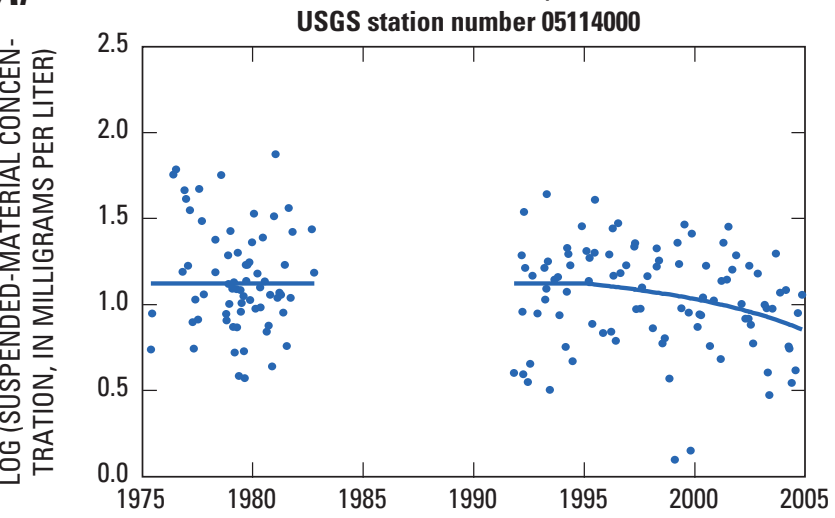

C.

lowa River at Wapello, lowa USGS station number 05465500

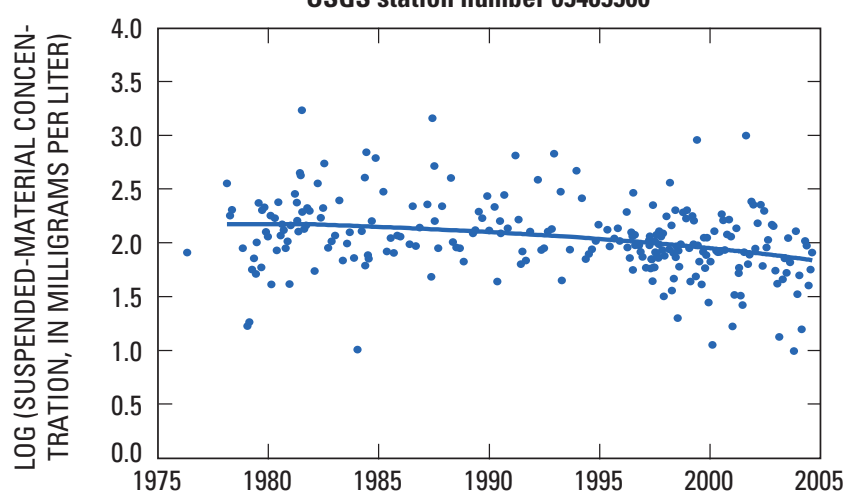

$\boldsymbol{E}$

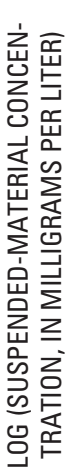

Maumee River at Waterville, Ohio USGS station number 04193500

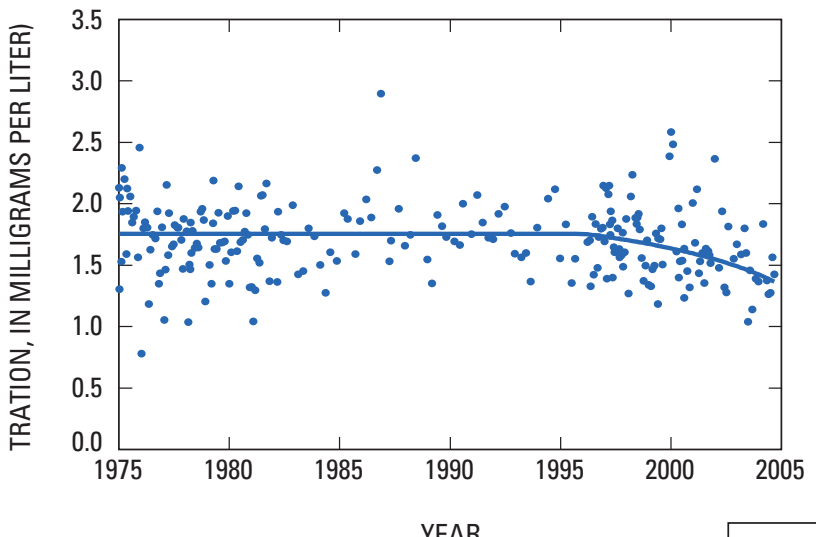

B. Chippewa River at Durand, Wisconsin USGS station number 05369500

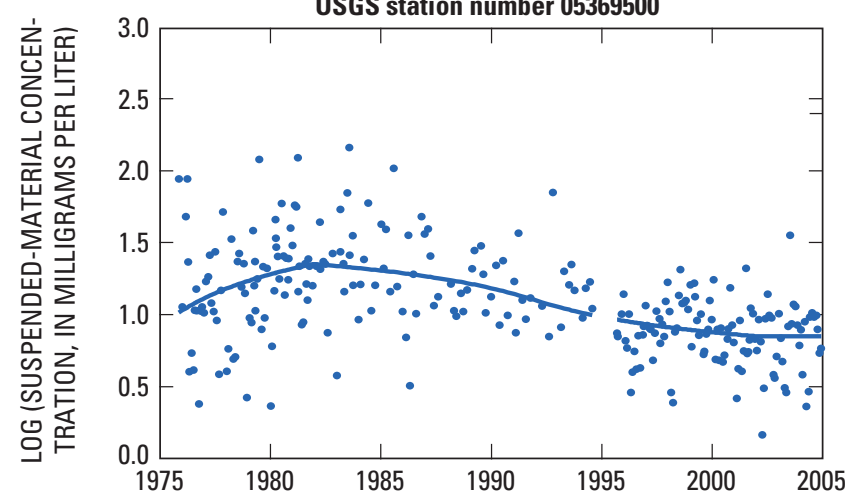

D.

Milwaukee River at Milwaukee, Wisconsin USGS station number 04087000

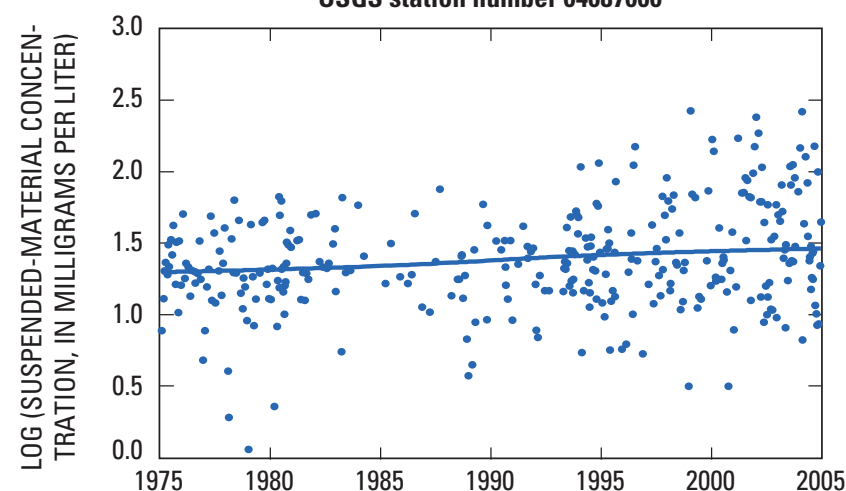

F. Mississippi River at Clinton, lowa

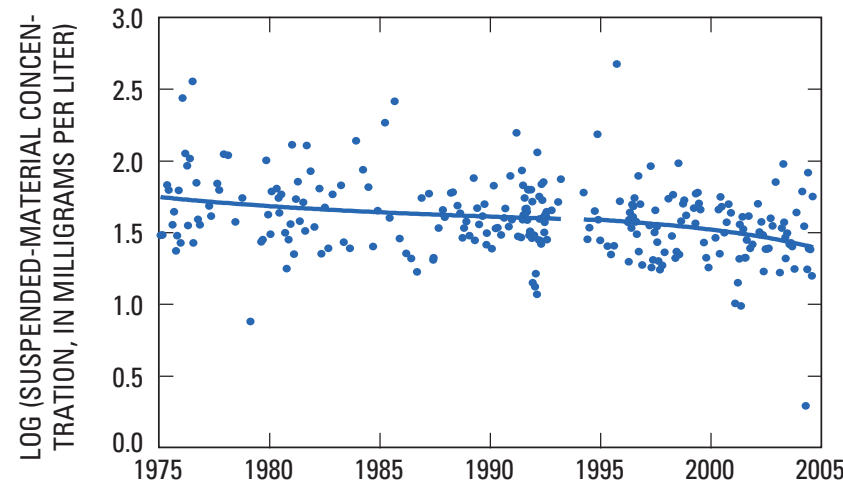

EXPLANATION

YEAR

LOESS smoothing line

Concentration

Figure 28. Long-term flow-adjusted trends in total suspended-material concentrations from 1975 to 2004 at six selected long-term sites. 


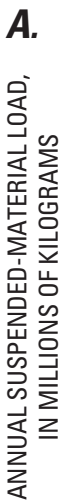

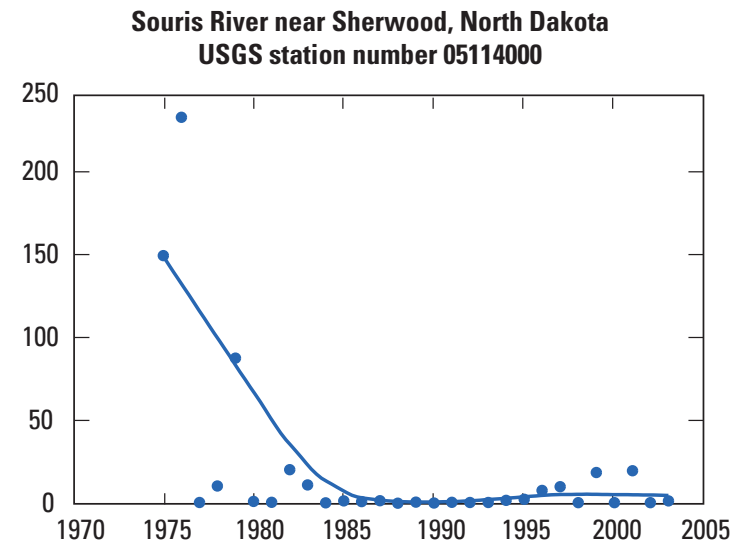

C.

lowa River at Wapello, lowa USGS station number 05465500

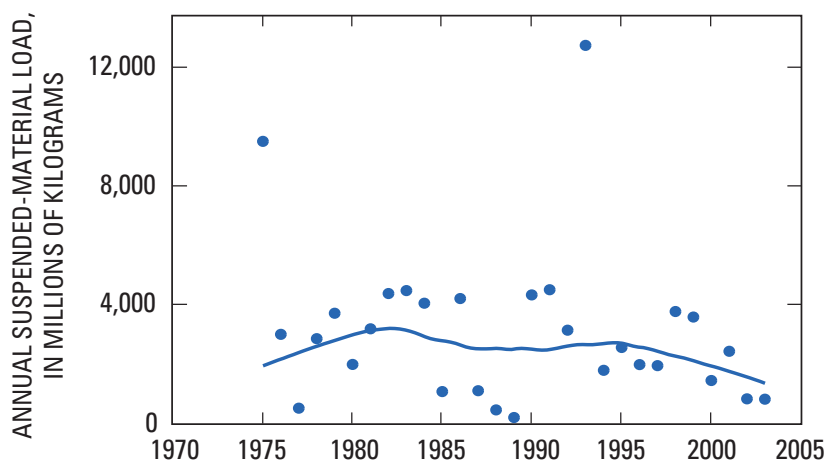

E.

Maumee River at Waterville, Ohio USGS station number 04193500

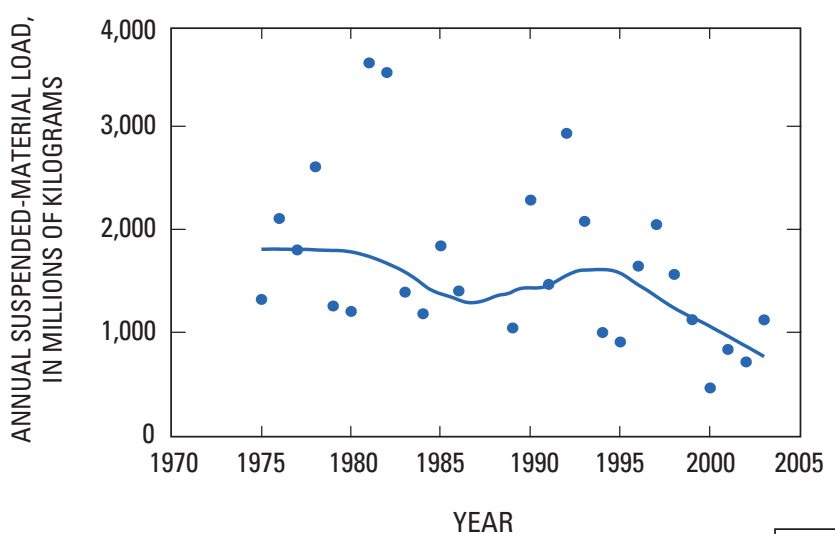

YEAR

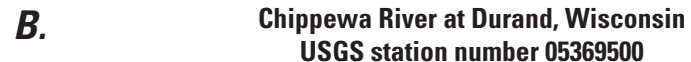

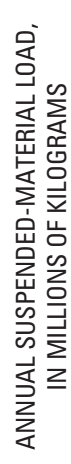
USGS station number 05369500

D.

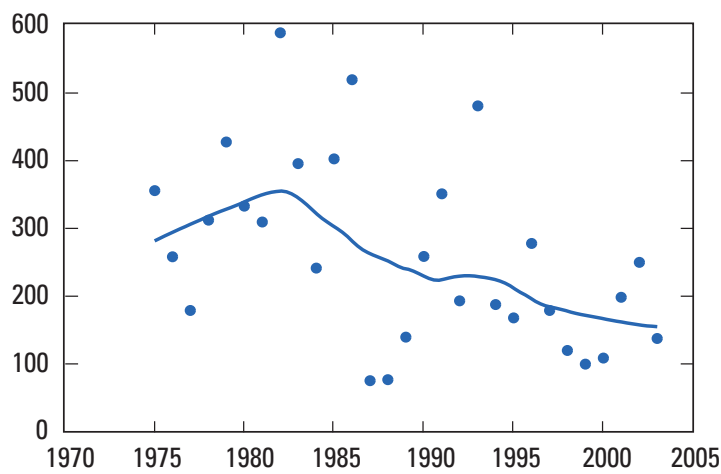

Milwaukee River at Milwaukee, Wisconsin USGS station number 04087000

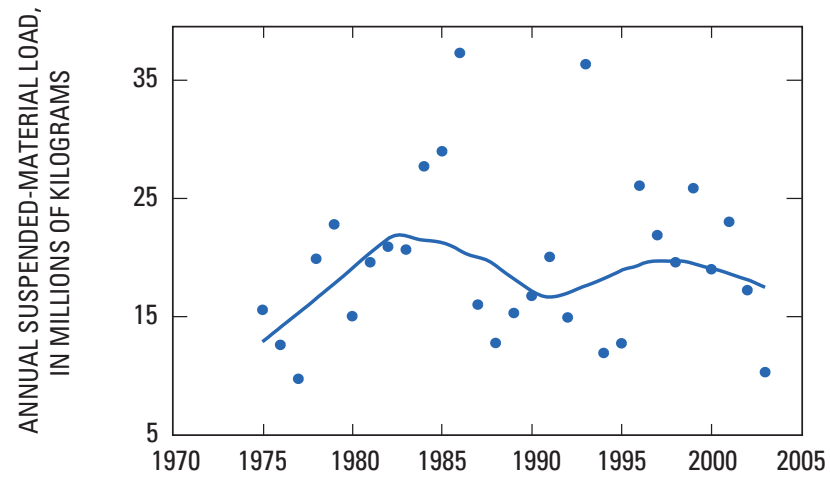

F.

Mississippi River at Clinton, lowa USGS station number 05420500

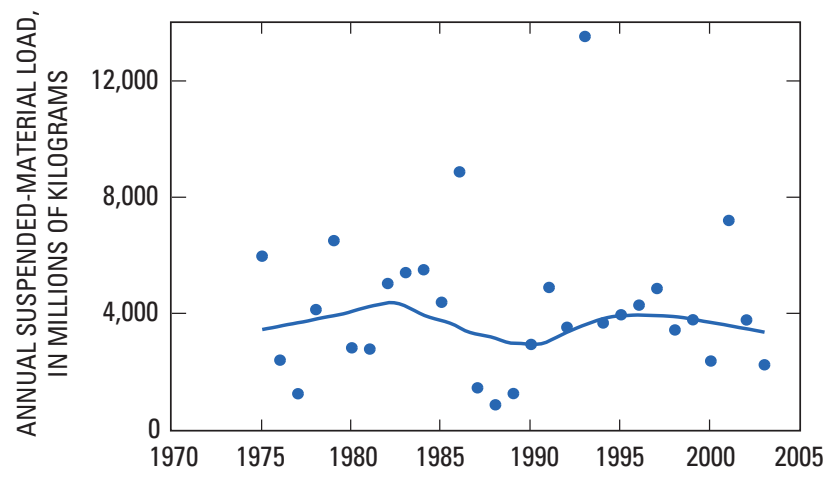

YEAR

EXPLANATION

LOESS smoothing line

Annual load

Figure 29. Long-term trends in total suspended-material loads from 1975 to 2003 at six sites in the study area. 


\section{Total Suspended Sediment}

The USGS generally analyzes water samples for total suspended sediment (SS, USGS parameter code 80154), whereas most State agencies analyze their samples for total suspended solids (USGS parameter code 00530). Gray and others (2000) found that total suspended solid concentrations generally were less than SS concentrations by about 25 to 34 percent because the analytical procedure for total suspended solids inadequately accounts for the amount of sandsized particles in the sample. This difference often is considered to be small compared to spatial differences that exist throughout large areas (Robertson and others, 2006); however, this bias may be significant when examining long-term trends. Therefore, SS data were analyzed separately to note potential bias in SMAT trends.

Median midmonthly SS concentrations from 22 trend sites ranged from 5.50 to $424 \mathrm{mg} / \mathrm{L}$, based on data from 1993 to 2004. The mean and median values of the median SS concentrations at these trend sites were 65.2 and $40.5 \mathrm{mg} / \mathrm{L}$, respectively. The highest concentrations again were in the western, southwestern, and south-central parts of the study area. The lowest concentrations were mostly in northern parts of Wisconsin and Michigan and in the northeastern part of the study area. The mean and median values based only on the SS data were slightly higher than those for SMAT when all of the sites that had only total suspended solids data were removed. This again indicates that SMAT concentrations may be biased slightly low compared to SS concentrations.

Median annual SS yields ranged from 1,620 to $939,000 \mathrm{~kg} / \mathrm{km}^{2}$ (table 15). The mean and median values of the median SS yields at these sites were 75,500 and $25,200 \mathrm{~kg} / \mathrm{km}^{2}$, respectively. Similar to SMAT yields, the highest SS yields were throughout the southern and eastern parts of the study area. The lowest SS yields were throughout the northern part of the study area.

\section{Trends in Total Suspended-Sediment Concentrations}

The spatial tendencies in the FA trends in SS concentrations from 1993 to 2004 resembled those for SMAT, but with several differences (table 15; fig. 30). The main difference was that some of the downward trends observed for the SMAT data in Wisconsin and New York and upward trends in Illinois were not observed for SS data because most of these sites only had total suspended-solids data. In addition, when the total suspended-solids data were removed from the Popple River data in northern Wisconsin, the upward trend in SS became significant. Of the 22 sites that had sufficient streamflow and SS concentration data for analysis (table 15), 15 sites had downward trends, of which 7 trends were statistically significant at $\mathrm{p}<0.10$, and 7 sites had upward trends, of which 3 trends were statistically significant.

When the OA trends in SS concentrations from 1993 to 2004 were examined, a few of the downward FA trends in Iowa and Illinois became statistically significant $(\mathrm{p}<0.10$; fig. 30). The differences between FA and OA trends in SS concentrations are again attributed to the trends in streamflow (fig. 12). Of the 22 trend sites, 16 sites had downward trends, of which 10 trends were significant, and 6 sites had upward trends, of which 1 trend was significant.

\section{Trends in Total Suspended-Sediment Loads}

From 1993 to 2004, most of the SS data showed a tendency toward decreasing loads. Nineteen of the 22 sites had a downward trend in SS loads (table 15; fig. 30C). Trends at 11 of the 19 sites with downward trends in loads were significant, but the trend at only one site with an upward trend was significant $(\mathrm{p}<0.10)$. The only site with a significant increase in loads was in northern Wisconsin. The slight upward trend in SMAT loads in the western part of the study area could not be confirmed because the western part of the study area could not be analyzed for SS trends.

\section{Understanding Water-Quality Trends in the Context of Human Activity}

Water-quality studies that summarize and analyze concentration or load data from many monitoring sites provide valuable insights into statewide, regional, or in some cases national trends. A monitoring site may have a downward trend in, for example TN concentrations, that is not statistically significant; however, when that trend is analyzed in a regional context where proximate sites have similar environmental characteristics, especially for the same type of land use, and significantly decreasing TN concentrations, then the downward trend at the original site becomes a candidate for inclusion as part of the broad regional downward trend. In this report, no statistical test was applied to the regional trend. Additional information is thus obtained by analyzing data in a regional context. 
Table 15. Summary of results for analyses of flow-adjusted trends, overall trends, and trends in loads for total suspended sediment (SS, USGS parameter code 80154),

1993 to 2004.

[USGS, U.S. Geological Survey; ID, identification; mg/L, milligram per liter; mg/L/yr, milligram per liter per year; \%/yr, percent per year; $\mathrm{kg}$, kilogram; $\mathrm{kg} / \mathrm{km}{ }^{2}$, kilogram per square kilometer; $\mathrm{kg} / \mathrm{yr}$, kilogram per year; NA, not available; $\mathrm{NC}$, not calculated; sites in bold indicate long-term evaluation sites]

\begin{tabular}{|c|c|c|c|c|c|c|c|c|c|c|c|c|c|c|c|}
\hline \multirow{3}{*}{$\begin{array}{l}\text { USGS } \\
\text { site } \\
\text { number }\end{array}$} & \multirow{3}{*}{$\begin{array}{c}\text { State-ID } \\
\text { number } \\
\text { (figure 1) }\end{array}$} & \multirow{3}{*}{$\begin{array}{c}\text { Water- } \\
\text { quality } \\
\text { model } \\
\text { (table 3) }\end{array}$} & \multicolumn{7}{|c|}{ Concentration } & \multirow{2}{*}{\multicolumn{6}{|c|}{ Annual loads }} \\
\hline & & & \multicolumn{4}{|c|}{ Flow-adjusted trend } & \multicolumn{3}{|c|}{ Overall trend } & & & & & & \\
\hline & & & $\begin{array}{c}\text { Reference } \\
\text { concentration } \\
\text { (mg/L) }\end{array}$ & $\begin{array}{c}\text { Trend } \\
\text { (mg/L/ } \\
\text { yr) }\end{array}$ & $\begin{array}{l}\text { Trend } \\
(\% / y r)\end{array}$ & p-value & $\begin{array}{c}\text { Trend } \\
\text { (mg/L/yr) }\end{array}$ & $\begin{array}{l}\text { Trend } \\
(\% / y r)\end{array}$ & p-value & $\begin{array}{c}\text { Median } \\
\text { annual } \\
\text { load } \\
(\mathrm{kg})\end{array}$ & $\begin{array}{c}\text { Median } \\
\text { yield } \\
\left(\mathbf{k g} / \mathbf{k m}^{2}\right)\end{array}$ & $\begin{array}{c}\text { Reference } \\
\text { load } \\
\text { (kg) }\end{array}$ & $\begin{array}{c}\text { Trend } \\
(\mathbf{k g} / \mathbf{y r})\end{array}$ & $\begin{array}{c}\text { Trend } \\
\text { (\%/ } \\
\text { yr) }\end{array}$ & p-value \\
\hline \multicolumn{16}{|c|}{ Central part } \\
\hline 04063700 & WI-9 & 3 & 4.0 & 0.823 & 2.78 & 0.000 & 0.727 & 18.35 & 0.000 & $1,130,000$ & 3,130 & 330,000 & 29,500 & 8.95 & 0.026 \\
\hline 04067500 & WI-10 & 5 & 4.6 & .033 & .72 & .721 & .031 & .67 & .789 & $16,500,000$ & 1,620 & $10,900,000$ & 69,000 & .64 & .849 \\
\hline 04073468 & WI-11 & 9 & 21.9 & .414 & 1.89 & .081 & .369 & 1.68 & .128 & 897,000 & 6,470 & 586,000 & $-6,200$ & -1.07 & .708 \\
\hline 04087000 & WI-13 & 7 & 32.5 & .549 & 1.69 & .308 & .403 & 1.24 & .464 & $23,800,000$ & 13,200 & $10,500,000$ & $-43,000$ & -.41 & .879 \\
\hline 05340500 & WI-15 & 3 & 5.6 & .159 & 2.83 & .369 & .086 & 1.54 & .631 & $59,400,000$ & 3,680 & $20,400,000$ & 57,800 & .28 & .937 \\
\hline 05389400 & IA-18 & 9 & 83.9 & -.074 & -.09 & .977 & -1.581 & -1.88 & .410 & $1,100,000$ & 12,500 & $2,080,000$ & $-110,000$ & -5.35 & .007 \\
\hline 05389500 & IA-19 & 3 & 30.9 & -.445 & -1.44 & .602 & -.706 & -2.28 & .364 & $2,140,000,000$ & 12,200 & $1,290,000,000$ & $-58,000,000$ & -4.53 & .049 \\
\hline 05420500 & IA-21 & 8 & 51.8 & -2.075 & -4.00 & .067 & -2.829 & -5.46 & .005 & $4,280,000,000$ & 19,300 & $2,790,000,000$ & $-200,000,000$ & -7.03 & .000 \\
\hline 05427718 & WI-22 & 9 & 40.4 & -1.257 & -3.11 & .000 & -1.942 & -4.80 & .000 & $2,210,000$ & 11,600 & 929,000 & $-56,000$ & -6.00 & .000 \\
\hline 05427948 & WI-23 & 8 & 33.7 & -1.006 & -2.98 & .000 & -1.046 & -3.10 & .000 & $1,410,000$ & 31,900 & 95,800 & $-3,300$ & -3.43 & .024 \\
\hline 054310157 & WI-24 & 8 & 48.1 & -1.422 & -2.95 & .007 & -1.410 & -2.93 & .010 & 447,000 & 39,800 & 59,400 & $-1,600$ & -2.76 & .280 \\
\hline 05465500 & IA-25 & 8 & 181.0 & -2.893 & -1.60 & .401 & -9.416 & -5.20 & .008 & $1,860,000,000$ & 57,300 & $1,640,000,000$ & $-120,000,000$ & -7.21 & .004 \\
\hline 05474000 & IA-26 & 7 & 207.0 & -4.453 & -2.15 & .267 & -12.022 & -5.81 & .007 & $1,420,000,000$ & 127,000 & $417,000,000$ & $-33,000,000$ & -7.80 & .006 \\
\hline 05481650 & IA-27 & 3 & 52.9 & -1.361 & -2.57 & .232 & -2.444 & -4.62 & .007 & $213,000,000$ & 14,100 & $166,000,000$ & $-13,000,000$ & -7.83 & .000 \\
\hline 05532500 & IL-32 & 3 & 129.0 & -11.148 & -8.64 & .038 & -11.653 & -9.03 & .025 & $178,000,000$ & 109,000 & $61,900,000$ & $-6,100,000$ & -9.87 & .017 \\
\hline 05543500 & IL-34 & 8 & 30.1 & .124 & .41 & .876 & -.501 & -1.66 & .505 & $540,000,000$ & 25,200 & $283,000,000$ & $-14,000,000$ & -4.95 & .045 \\
\hline 05586100 & IL-37 & 9 & 140.9 & 7.302 & 5.18 & .068 & 2.130 & 1.51 & .552 & $3,260,000,000$ & 47,000 & $2,830,000,000$ & $-130,000,000$ & -4.43 & .131 \\
\hline \multicolumn{16}{|c|}{ Eastern part } \\
\hline 03085000 & PA-40 & 8 & 12.6 & -0.485 & -3.86 & 0.331 & -0.351 & -2.79 & 0.517 & $630,000,000$ & 33,100 & $83,000,000$ & $-770,000$ & -0.93 & 0.865 \\
\hline 03353637 & IN-42 & 8 & 20.1 & -.267 & -1.32 & .531 & -.471 & -2.34 & .309 & $3,780,000$ & 85,800 & 170,000 & $-7,500$ & -4.39 & .278 \\
\hline 04186500 & $\mathrm{OH}-43$ & 7 & 47.4 & -3.272 & -6.90 & .001 & -3.301 & -6.96 & .002 & $32,500,000$ & 37,700 & $3,550,000$ & $-250,000$ & -7.10 & .081 \\
\hline 04193500 & OH-44 & 9 & 32.9 & -1.322 & -4.02 & .008 & -1.268 & -3.86 & .043 & $1,040,000,000$ & 63,600 & $61,900,000$ & $-2,200,000$ & -3.54 & .347 \\
\hline 04237946 & NY-49 & 9 & 984.6 & -13.718 & -1.39 & .288 & -14.079 & -1.43 & .280 & 778,000 & 939,000 & 608,000 & $-7,100$ & -1.17 & .518 \\
\hline
\end{tabular}




\section{A. Flow-adjusted trend in concentrations}

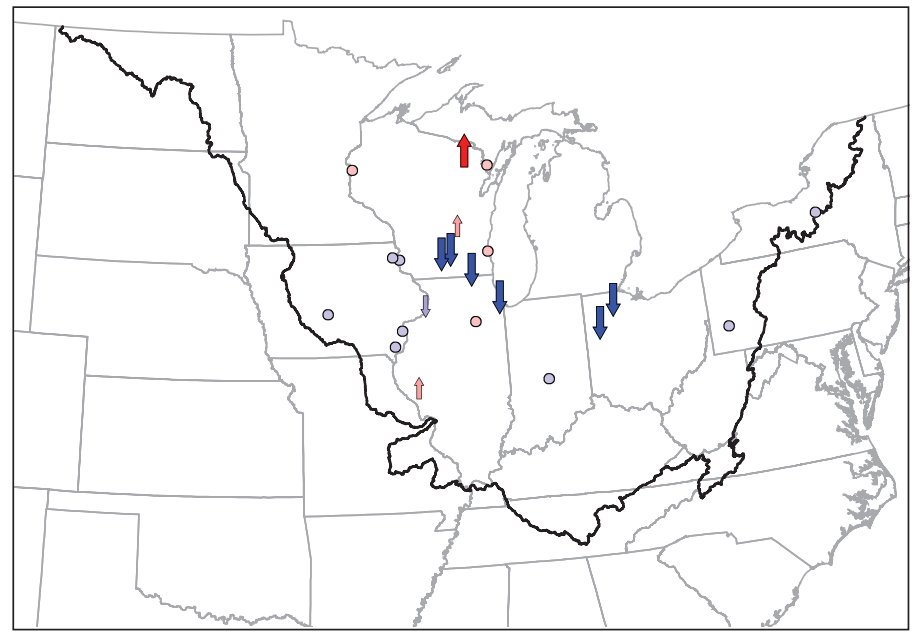

\section{Total}

Suspended Sediment

\begin{tabular}{|l|}
\hline \multicolumn{1}{|c|}{ EXPLANATION } \\
Trends \\
i Upward $(\mathrm{p}<0.05)$ \\
î Upward $(0.05 \leq \mathrm{p}<0.1)$ \\
$\circ$ Upward $(\mathrm{p} \geq 0.1)$ \\
$\circ$ Downward $(\mathrm{p} \geq 0.1)$ \\
$\Downarrow$ Downward $(0.05 \leq \mathrm{p}<0.1)$ \\
$\Downarrow$ Downward $(\mathrm{p}<0.05)$ \\
\hline
\end{tabular}

\section{B. Overall trend in concentrations}
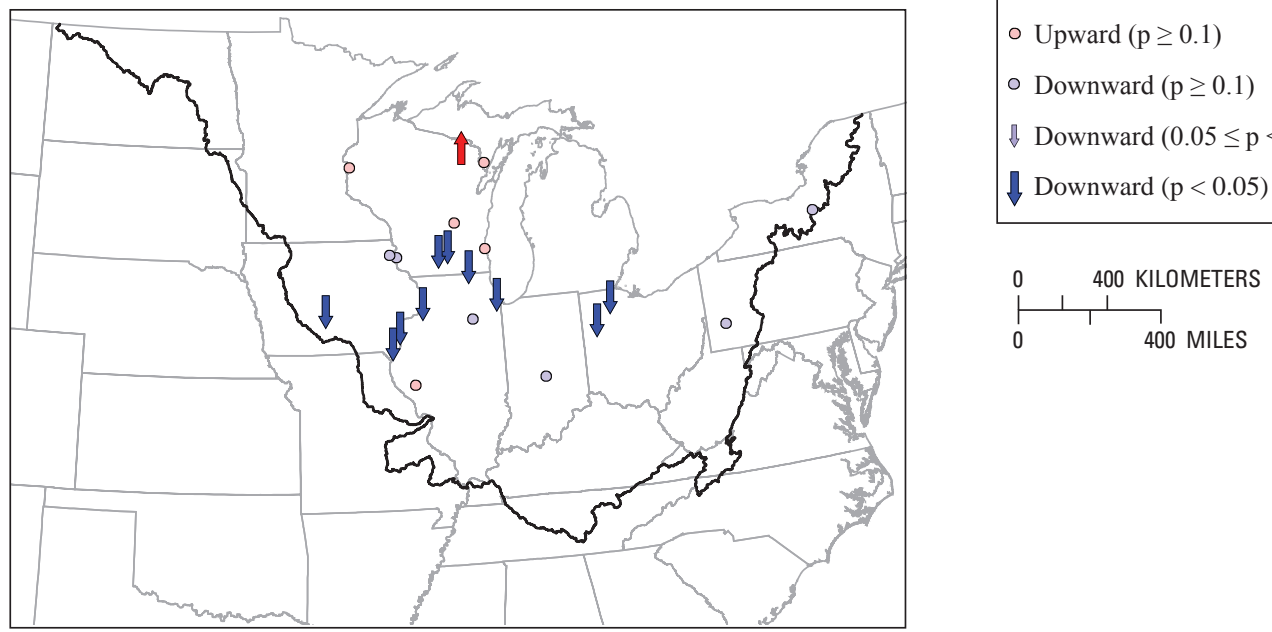

\section{Trend in annual loads}

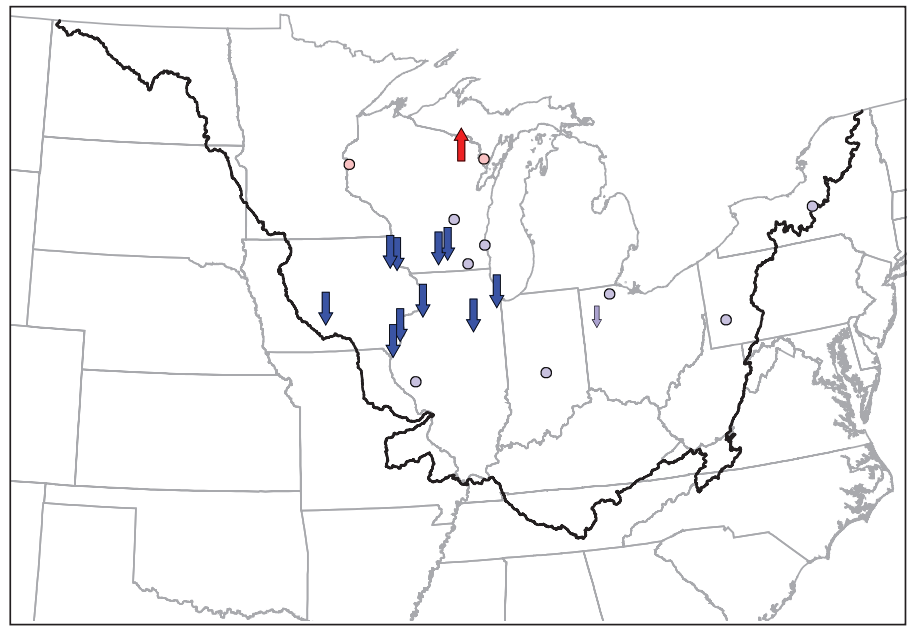

Figure 30. Trends in total suspended sediment from 1993 to 2004 for $\boldsymbol{A}$, flow-adjusted concentrations, $\boldsymbol{B}$, overall concentrations, and $\boldsymbol{C}$, annual loads throughout the study area. 
Ideally, any regional trends in concentrations or loads would be linked to changes in sources in a cause-and-effect relation. Mosteller and Tukey (1977) proposed that four conditions should be satisfied to define a cause-and-effect relation: (1) an association, such as a statistically significant correlation between the source variable and the response variable; (2) responsiveness, such as both proportional increases and decreases in response to the correlated changes in the source variable; (3) a mechanism to explain the relation; and (4) consistency, which requires that the relation should be repeatable at more than one location. Defining or proving cause-andeffect relations can be time-consuming, data-intensive, and costly. Few programs or studies have sufficient resources to establish such relations at statewide, regional, or national levels. One type of analysis used in this report to indicate causeand-effect relations is the consistency in the patterns in the trends in nutrient inputs and the patterns in the trends of the water-quality data. These spatial associations are qualitative, but they are strengthened by the consistency of a large number of sites. A second type of analysis used to derive possible cause-and-effect relations is a regression approach between the changes in concentrations and yields at selected sites and the changes in land use and the amount of a specific source of nutrients or sediment. Flow-adjusted trends in concentrations, being independent of streamflow conditions, are best used to evaluate changes in water quality arising from changes in management activities within a basin. Flow-adjusted trends are therefore examined in this section to try to describe potential cause-and-effect relations in the context of human activities.

\section{Total Nitrogen}

Of the 24 sites examined for FA trends in TN concentrations, 19 sites had upward trends, and 5 sites had downward trends (fig. 15A). The FA trend patterns for TN are similar to the trends in fertilizer nitrogen applications (fig. 7B). The similarity in the patterns of these trends indicates a broad regional association between $\mathrm{FA}$ trends in $\mathrm{TN}$ and fertilizer applications.

The FA trends in TN concentrations at 10 of these sites had significant $(p<0.10)$ trends, most of which were in the central part of the study area (fig. 15A). Six of these sites (05082500, 04087000, 05287890, 05420500, 05465500, and 05586100) were classed as agricultural, and FA trends were upward at all these sites except 05082500 . Three sites with significant upward trends (04063700, 05369500, and $05382000)$ were classed as forested. One site with a significant downward trend (05540275) was classed as mixed. The forested sites in northern Wisconsin and the Upper Peninsula of Michigan also may be affected by the increase in atmospheric deposition of nitrogen (fig. 9B). Because nitrogen input from fertilizers is the dominant source of nitrogen in agricultural areas, the annual value in each basin was analyzed in a regression analysis to put the trend into the context of human activity. Atmospheric deposition was used as an ancillary variable in the analysis of trends at the forested sites because that is the major source of nitrogen in those basins. Nitrogen from fertilizer applications was not significant at $\mathrm{p}<0.10$ for any agricultural site. The lack of significance indicates that many factors affect TN in streams, such as agricultural practices including artificial drainage, land-retirement plans, tillage practices, and animal husbandry. The use of nitrogenous fertilizers has remained relatively stable over the 12-year period, increasing in some areas and decreasing in others (fig. 7B). The significant upward trends in TN concentrations at the five agricultural sites and upward trends at several of the other sites indicate that efforts to reduce runoff from agricultural lands have not been universally successful. At least two reasons account for that lack of success - the first is that local benefits do not necessarily translate to basinwide benefits, and the second is that unregulated activities such as tile drainage may counteract any benefit from efforts to reduce agricultural runoff. Nitrogen as nitrate moves easily through the soils to tile drains and into streams. In tile-drained areas, nitrate makes up most of the TN in the streams (Baker and others, 2006). Because much of the row cropland in the study area is heavily tiled (Strock and others, 2007), much of the nitrate enters streams by bypassing best management practices such as filter strips (Baker and others, 2007; Strock and others, 2007). Another confounding factor is the growth of confined animal feeding operations (CAFOs) in the study area (Horne, 2000). These CAFOs are highly regulated - the Clean Water Act (U.S. Environmental Protection Agency, 2006a) requires operators to carry a national pollutant discharge elimination system permit; the concentration of animal waste requires proper disposal.

Annual atmospheric deposition inputs were significant at $\mathrm{p}<0.10$ for two of the three forested sites, and fertilizer input was significant at one site (04063700). The results for the atmospheric deposition analysis indicate that the atmospheric deposition of nitrogen may have some effect on TN concentrations in streams.

The mixed site had a downward trend, which indicates that urban controls on nitrogen could have been effective in reducing total nitrogen in that stream. Unfortunately, no ancillary data pertaining to urban controls are available to test that conclusion.

\section{Dissolved Ammonia}

One of the goals of the Clean Water Act (U.S. Environmental Protection Agency, 2006a) is to reduce ammonia concentrations in streams through management of both animal and human wastes. The widespread, downward trends in NH4 concentrations for the 36 trend sites indicate that those goals are being met; 24 of the 36 trend sites had significant downward trends $(\mathrm{p}<0.10)$. Regionally, good agreement exists between FA trends in NH4 concentrations (fig. 18A) and change in manure nitrogen application rates (fig. $8 \boldsymbol{B}$ ), except in the farthest western part of the study area.

The strength of the relation between FA trends in NH4 concentrations and the percent change in manure nitrogen was 
evaluated for agricultural sites. The p-value of the Spearman rank correlation estimate was 0.13 , which indicates that the relation is not statistically significant at $\mathrm{p}<0.10$. This finding implies that although reduction in manure input may partially account for the reduction in FACs for NH4, other efforts, such as improved wastewater treatment, have contributed to the observed downward trends.

The median values of the reference concentrations were about $0.05 \mathrm{mg} / \mathrm{L}$ for sites with no significant trends and about $0.06 \mathrm{mg} / \mathrm{L}$ for sites with significant trends. Those two medians are not substantially different. However, the range in concentrations was smaller for those sites that did not have significant trends than those that did, which indicates for sites without significant trends that either NH4 was never an issue or that controls on waste had been effective earlier. The site that had a significant upward trend, Northrup Creek, N.Y. (0422026250), had a reference concentration of $0.032 \mathrm{mg} / \mathrm{L}$. Land use at that site was classified as mixed, and the site has a relatively small drainage area of $26 \mathrm{~km}^{2}$, which implies that a very small, possibly local, source may be responsible for the trend observed at that site.

\section{Total Kjeldahl Nitrogen}

The FA trends in KJN concentrations from 1993 to 2004 showed no distinct spatial pattern. Of the 36 sites that had sufficient streamflow and KJN concentration data for analysis (table 8; fig. 19A), 17 sites had downward trends, and 19 sites had upward trends in concentrations. Seven sites had significant downward trends, and six sites had significant upward FA trends $(\mathrm{p}<0.10)$. In general, human activities that affect KJN are the processing of human and animal waste, which can affect both NH4 and organic nitrogen in streams. A comparison between the change in TN from manure from 1992 to 2002 (fig. 8B) and the FA trends in KJN concentrations (fig. 19) indicates that less manure was produced in all of the basins in 2002 than in 1992, except for the Maumee River, Ohio (04193500), which had a slight increase in manure production and a significant upward trend in FA concentrations. The broad decrease in manure production in most basins does not explain the significant upward trends in KJN at the remaining five sites. The p-value of the Spearman rank correlation test was 0.49 . Human population was constant or increased in all but three basins from 1990 to 2000. The p-value of the Spearman rank correlation between KJN trends and changes in human population was 0.56 . The increase in human population and apparent decrease in animal manure production are competing factors that confound the interpretation of trend in KJN concentrations. Other confounding factors are the changes in treatments of those human and animal wastes.

\section{Dissolved Nitrite Plus Nitrate}

The FA trends in NO2NO3 concentrations from 1993 to 2004 showed no distinct spatial pattern (fig. 20A). Of the 29 sites that had sufficient data for analysis, 12 sites had downward trends, and 17 sites had upward trends in concentrations. Some general agreement exists between the FA trends in $\mathrm{NO} 2 \mathrm{NO} 3$ concentrations (fig. 20A) and the change in nitrogen fertilizer application (fig. 7B). The small changes in the forested sites in northern Wisconsin are consistent with the changes in atmospheric deposition of nitrogen (fig. 9).

Only two sites-Milwaukee River, Wis. (04087000) and Chippewa River, Wis. (05369500) — had significant $(\mathrm{p}<0.10)$ positive relations between FA trends in $\mathrm{NO} 2 \mathrm{NO} 3$ concentrations and the logarithm of nitrogen fertilizer application as an ancillary variable for trend. Another site, Little Buck Creek, Ind. (03353637), had a significant negative relation between FA trends in $\mathrm{NO} 2 \mathrm{NO} 3$ concentrations and the logarithm of nitrogen fertilizer application; that is, increasing fertilizer application resulted in a decrease in concentrations, which contradicts a reasonable mechanism, although the substantial decrease in manure applications, about 80 percent decrease, could explain the downward trend.

An issue related to downward trends in $\mathrm{NH} 4$ concentrations often is an associated upward trend in $\mathrm{NO} 2 \mathrm{NO} 3$ concentrations, which could be a product of the microbiologically mediated oxidation of NH4. Three sites-Milwaukee River, Wis. (04087000), Iowa River, Iowa (05465500), and Illinois River, Ill. (05586100) — had significant upward FA trends in $\mathrm{NO} 2 \mathrm{NO} 3$ concentrations; however, none of these sites had significant downward FA trends in NH4 concentrations. Two sites-Little Buck Creek, Ind. (03353637) and Spring Brook, Ill. (05540275) - had significant downward FA trends in NO2NO3 concentrations. Both of these sites had significant downward FA trends in NH4 concentrations, and both sites are very urbanized and have 45 and 27 percent urban land cover, respectively.

\section{Total Phosphorus}

From 1993 to 2004, FA trends in TP concentrations were upward at 24 of the 40 sites (fig. 22A). The 24 sites with upward trends were distributed throughout the entire study area; however, most of these sites were in the central part and the eastern side of the western part of the study area. Twelve of these sites, mostly in the central part of the study area, had significant upward trends $(\mathrm{p}<0.10)$. Downward trends were significant at 7 of the 16 sites, mostly in Wisconsin and the eastern part of the study area. A weak agreement exists between these trends and the trends in phosphorus fertilizer application (fig. 7C). Both trends indicate increases west of the Mississippi River and decreases in Wisconsin and eastern part of the study area. However, several sites in central and northern Illinois and in western Wisconsin are not consistent with this relation and had significant upward trends in TP concentrations $(p<0.05)$. These concentration increases may be associated with increases from local point sources. 
Changes in the amount of phosphorus fertilizer use are consistent with the trend in FA trend in TP concentrations at four sites - Green Lake Inlet, Wis. (04073468), Pheasant Branch, Wis. (05427948), Jackson Creek Tributary, Wis. (054310157), and Northrup Creek, N.Y. (0422026250)_all of which had significant downward trends. However, phosphorus fertilizer use was negatively associated with the FA trend in TP concentrations at six sites $(\mathrm{p}<0.05)$, which contradicts its use in explaining the observed trend at these sites. The lack of a strong association between phosphorus fertilizer use and FA trends in TP concentrations indicates that other factors are important in determining TP concentrations in streams.

\section{Dissolved Phosphorus}

The FA trends in DP concentrations from 1993 to 2004 showed mixed regional tendencies; however, DP concentrations consistently decreased at all of the sites in the eastern part of the study area (fig. 25A). Many of the sites with significantly decreasing TP concentrations had little change in DP concentrations. Of the 35 sites analyzed, 23 sites had downward trends in DP concentrations; most of these sites were east of the Mississippi River, and they included 10 of the 12 sites with significant $(\mathrm{p}<0.10)$ downward trends. A comparison of these patterns with those of nonpoint phosphorus inputs (fig. 10C) and those for fertilizers and manure indicate fairly good regional agreement indicating that reduction in fertilizers and manure east of the Mississippi River could explain most of the observed trends in DP concentrations. Some discrepancies occur in Illinois, but those could be caused by nonagricultural influences.
Excluding the sites classified as urban in part of the study area east of the Mississippi River, 7 of the remaining 11 sites have a significant positive relation between the FA trends in DP concentrations and the logarithm of phosphorus fertilizer application rates as an ancillary variable in a regression analysis. No sites west of the Mississippi River had a significant relation between the FA trends in DP concentrations and phosphorus fertilizer application rates. This again indicates that the reductions in phosphorus fertilizer application rates possibly have had some effect on the concentration of phosphorus in the streams.

With the exception of one site, Spring Brook, Ill. (05540275), the correlation between trends in phosphorus fertilizer use and FA trends in DP concentrations was significant (fig. 31; Spearman correlation coefficient p-value was less than 0.05). Although most sites had downward trends in farm phosphorus use and FACs for DP — two sites Salt Creek, Ill. (05531500), and Des Plaines River, Ill. (05532500)— - had the opposite relation. Land use at both of these sites was classified as predominantly urban. The urban and mixed sites had no significant relation between trends in phosphorus fertilizer use and FA trends in DP concentrations (fig. 31). All of the urban and mixed sites were well above the $1: 1$ reference line in figure 31, indicating that sources other than farm fertilizers affect the FA trends at those sites. In addition, all urban and mixed sites, except 05531500 , had upward trends in nonfarm phosphorus fertilizer use, but FA trends in DP concentrations were mixed-four sites had downward trends and four sites had upward trends.

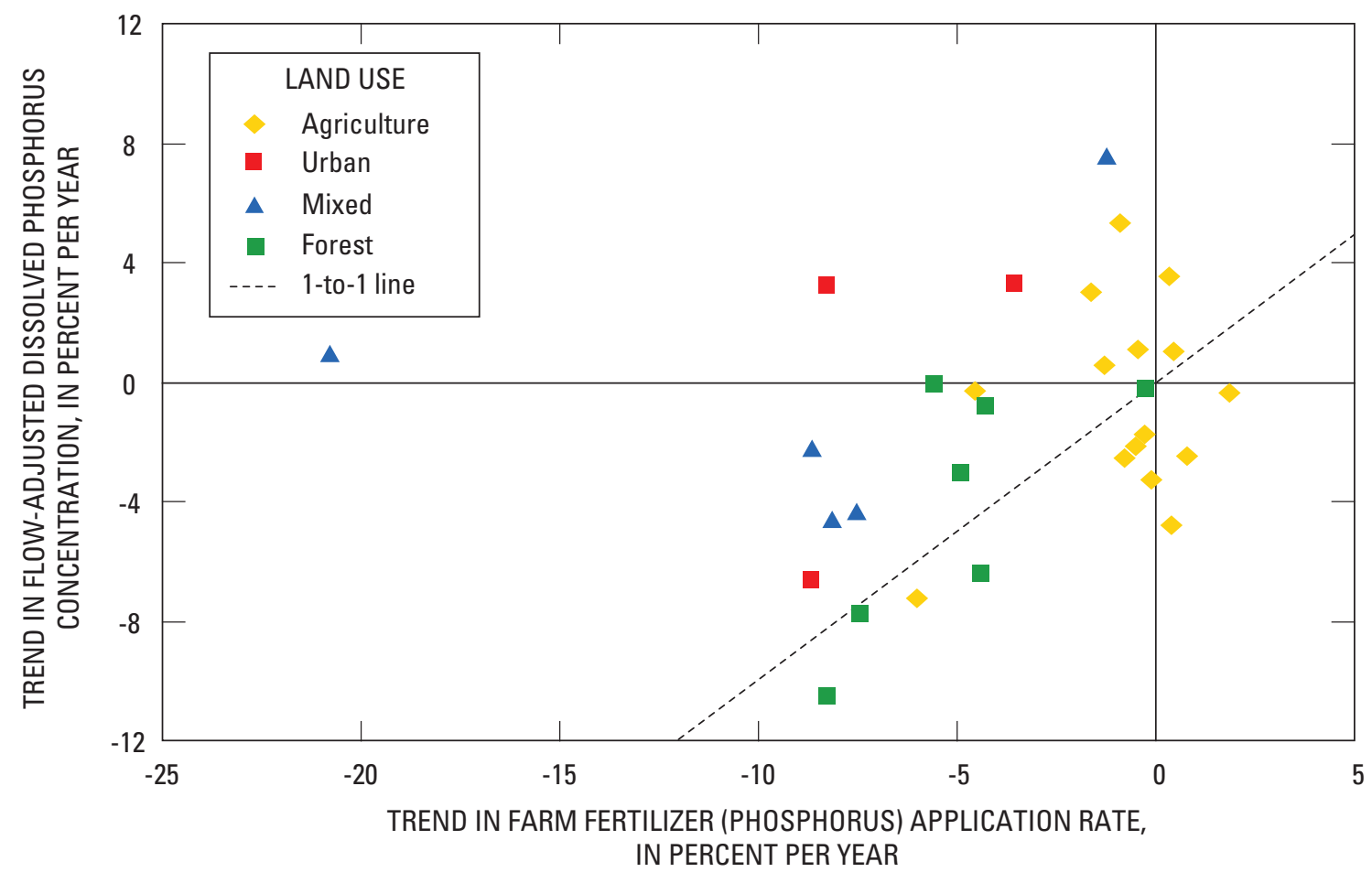

Figure 31. Relation between trends in flow-adjusted dissolved phosphorus concentrations and trends in phosphorus inputs from farm fertilizers for sites with varying types of land use in the basin, 1993 to 2004. 


\section{Total Suspended Materials}

The FA trends in SMAT concentrations from 1993 to 2004 showed distinct spatial patterns (fig. 27), with significant upward trends in Illinois, and downward trends throughout most of Wisconsin, Iowa, and in the eastern part of the study area (fig. 27A). Of the 42 sites, 12 sites, mostly east of the Mississippi but not in Illinois, had significant $(p<0.10)$ downward trends. All but one of the five sites with statistically significant increases in SMAT were in Illinois. A comparison of these patterns with those of FA trends in TP concentrations (fig. 22A) indicates fairly good regional agreement.

To better determine if the FA trends in SMAT concentrations (fig. 27A) were related to the FA trends in TP concentrations (fig. 22A), the log-transform of FACs for SMAT was included as an ancillary variable in the regression models that showed significant FA trends in TP concentrations. The log-transform of SMAT was significant $(p<0.10)$ at 16 of the 19 sites. The log-transform of SMAT concentrations was not significant at one site (05114000), and data for two Red River of the North sites - 05064500 in Minnesota and 05082500 in North Dakota - were insufficient to evaluate the relation. This indicates that the FA trends in TP concentrations are strongly related to the FA trends in SMAT concentrations, which is very reasonable because TP includes phosphorus bound to suspended material.

FA trends in SMAT can be related to agricultural practices, urbanization, and forest management. The widespread downward FA trends in SMAT concentrations indicate that best management practices may have had some effect on reducing suspended material in many of the streams. The upward trends in Illinois are in urban and heavily agricultural areas and indicate that there may be confounding factors in the Illinois River Basin. Many types of human activity in streams, such as construction or removal of dams or bridges, can affect suspended material in streams. Natural changes, such as degradation or aggradation of the stream bed, also can affect suspended material. Ancillary data about these activities and changes are not broadly available and complicate the interpretation of trends in suspended material.

\section{Changes in Loads from 1993 to 2004 in a Longer Term Context}

Changes in TN, TP, and SMAT loads were examined from 1975 to 2003 at six sites (figs. 17, 24, and 29). These changes were examined to provide a longer term perspective on the data examined for the 1993 to 2004 period. The longterm, nonmonotonic trends, which were shown as curves on the 1975-2003 graphs, were generated by LOESS smoothing, a type of moving average function. The statistical significance of those trends over the 1975-2003 period cannot be determined; however, the long-term changes for annual streamflow and load data indicate that the monotonic trends from 1993 to 2004 should not be extrapolated backward in time.

Examination of the longer term (1975-2003) mean annual streamflow data (fig. 13) and associated loads of TN (fig. 17), TP (fig. 24), and SMAT (fig. 29) at the six long-term sites indicates that the trends in streamflow and associated loads from 1993 to 2004 are not, in most cases, simple continuations of longer term linear trends; rather, the changes consist of a series of increases and decreases in streamflow and the associated loads. Most of the changes in long-term loads are directly caused by changes in streamflow rather than changes in nutrient or sediment concentrations resulting in longterm changes in loads resembling the long-term changes in streamflow. The most prominent example of this is in data for streamflow, and TN, TP, and SMAT loads at the Souris River, N. Dak., from 1975 to 2003. During this time, both streamflow and the associated loads, although trending downward, were all substantially larger during the 1970s and early 1980s than during 1993-2004 (figs. 13A, 17A, 24A, and 29A). Streamflow and associated TN, TP, and SMAT loads in the Souris River are to some extent artificially controlled by the large Canadian dams located upstream, especially in the 1993-2004 period when two of the dams were constructed.

In addition, a few of the sites are in the same basin and, therefore, trends should resemble one another. For example, the Chippewa River (site 16 in fig. 11) is in the UM Basin upstream from the Mississippi River at Clinton, Iowa (site 21 in fig. 11), which partially accounts for the similarities in trends in the streamflow and loads at these two sites (figs. 13B,F; 17B,F; 24B,F; and 29B,F). The largest exception to the general bimodal similarity, which was caused by similarities in climate over the UM region, is a local wet year recorded at the Chippewa Basin during 2002 that was not representative of conditions in the larger UM Basin upstream from Clinton. This difference resulted in the LOESS curves for streamflow, TN, and TP at the Chippewa River site trending upward during 2000-2003, whereas those for the Mississippi River at Clinton trended downward.

Annual precipitation across the study area (fig. 4) and associated streamflow and loading at the Iowa River at Wapello, Iowa, and at the Maumee River, Ohio, varied substantially during 1975-2003 (figs. 13C,E; 17C,E; 24C,E; and $29 \boldsymbol{C}, \boldsymbol{E}$ ). The wet years generally averaged out with the dry years because the LOESS procedure at these two sites do not show any substantial or sustained upward or downward trends during this period. With the exceptions of the unusually dry year in 1989 and the unusually wet year in 1993 for the Iowa River at Wapello, Iowa, the short-term trends in streamflow, TP, TN, and SMAT during 1993-2004 generally were representative of conditions during the longer term period 1974-2003.

Unlike streamflow and TP loads, SMAT loads in the Maumee River decreased during 1996-2003 relative to 1975-1995 (fig. 29). Such a decrease in SMAT loads relative to streamflow is of interest in the Maumee River Basin, 
because the Maumee River has been identified as being the single greatest contributor of sediment to Lake Erie and is an official USEPA "Area of Concern" for this and other waterquality problems (U.S. Environmental Protection Agency, 2007). Because the FA trend in SMAT concentrations during 1993-2004 is significantly downward (fig. 27, table 13) and although the trend in streamflow is slightly upward (fig. 12, table 4), the decrease in SMAT loads could be attributed to implementation of sediment control practices in the Maumee River Basin, which began in 1987 (U.S. Environmental Protection Agency, 2007).

The Milwaukee River at Milwaukee, Wis., drains to Lake Michigan and has the smallest drainage area of the six sites selected for the long-term analysis. Annual TN and TP loads for the Milwaukee River during 1975-1989 (figs. 17D; 24D) were larger than those measured during 1993-2004 because of trends in annual precipitation (fig. 4) and associated streamflow (fig. 13D). The SMAT loads during 1975-1984 showed an upward trend, but not substantially different in magnitude than during 1985-2004 (fig. 29D).

\section{Understanding Trends in Loads in the Context of Climatic Variability}

The insights provided by data in figures $13,17,24$, and 29 from sites that have a long history of streamflow and waterquality monitoring demonstrate the value of establishing and maintaining a long-term streamflow and water-quality monitoring network for planning purposes in the United States, especially as current thought (Solomon and others, 2007) indicates that global warming could lead to large-scale changes in the climate of North America during the 21st century. In general, such large-scale regional changes in climate and associated hydrology could necessitate modifications to urban infrastructure if changes occur in lake levels, flood crests, or flood frequency, or if lesser rainfall in some areas places unanticipated strains on water use and sewerages.

The nutrient and sediment loads described in this report primarily are controlled by changes in streamflow rather than changes in concentration, as governed by the substantially larger magnitude of the streamflow coefficients in all load computations relative to the much smaller concentration coefficients. In almost all cases for both the short-term loads (1993-2004) and the long-term loads (1975-2003), changes in loading closely mirror changes in streamflow because of dominance of streamflow coefficients. Sources of nitrogen, phosphorus, and sediment were relatively steady over the study period. Therefore, changes and trends in annual loading primarily were attributed to long-term trends and the regional distribution of precipitation (fig. 4) or water use, such as dam management or irrigation, and associated streamflow rather than the magnitude of trends in TP, TN, and SMAT concentrations. The implication of streamflow dominance in the load computations is that the 12-year loads presented in this report could be at least crudely estimated backward to the mid-1970s if a streamflow record exists for the period of interest and an assumption is made that nutrient and sediment sources did not change substantially in the basin during the period of interest.

The strong influence of streamflow on nutrient and sediment loads implies that long-term trends in loads can be more sensitive to changes in climate rather than anthropogenic changes. For example, SMAT data for the Souris River, N. Dak., shown on figure 29A, might indicate that the substantial reduction in loads during the period 1975-1983 is attributed to some widespread implementation of an effective agricultural best-management practice for sediment control or improvements in industrial or sewage treatment plant processes; however, further consideration is required to understand the loads. As previously described, the streamflow in the Souris River decreased dramatically through time and, in addition, the Souris River is downstream from major dams in Canada, so streamflow in the Souris River is artificially controlled. Therefore, examination of FA trends in concentrations provides much more information regarding the effects of anthropogenic practices.

\section{Comparison between Nutrient Loads from This Study and Loads Contributing to the Gulf of Mexico Hypoxic Zone}

In addition to degrading the local quality of the streams, the nutrients and sediments transported in the streams can cause problems in downstream reservoirs, lakes, and coastal ecosystems. An increasing supply of nutrients, primarily nitrogen, from the Mississippi River Basin has been implicated as one of the main causes for the expanding hypoxic zone in the Gulf of Mexico (Rabalais and others, 2002; Goolsby and Battaglin, 2000). The Mississippi River and its distributary, the Atchafalaya River, drain an area of about 3,200,000 $\mathrm{km}^{2}$, or about 41 percent of the conterminous United States. In an average year, the Mississippi-Atchafalaya River (MAR) Basin contributes about 1,568,000,000 kg of TN to the Gulf of Mexico (Goolsby and others, 1999).

Relative loading (yields) of nitrogen from the individual tributaries of the Mississippi River are not uniform. To better define where these nutrients originate, Goolsby and Battaglin (2000) quantified the TN loading from 42 large drainages within the Mississippi River Basin, including the Mississippi River at Clinton, Iowa, by use of a multiple regression approach, which is a method similar to that used in this study to compute loads. They then related these data to various nitrogen sources to estimate yields from similar sized drainages throughout the entire basin. They found that the highest $\mathrm{TN}$ yields were from areas with the highest streamflow, precipitation, and nitrogen inputs, primarily fertilizers; the highest yields were from drainages in the Ohio and middle part of the Mississippi River Basins. For 
the period from 1980 to 1996, they found that the UM Basin contributed 9.6 percent or $149,800,000 \mathrm{~kg}$ of the TN load of $1,568,000,000 \mathrm{~kg}$ to the Gulf of Mexico from the MAR Basin, whereas the UM Basin represented only about 6.9 percent of the entire area. The load computed at the Mississippi River by Goolsby and Battaglin (2000) at Clinton, Iowa, is similar to that computed in this study of $149,300,000 \mathrm{~kg}$ for the same years. Only the Ohio River Basin and middle part of the Mississippi River Basins contributed a relatively higher percentage of the total load than the UM Basin. Goolsby and Battaglin (2000) found that streams draining Iowa and Illinois contribute as much as 35 percent of the TN flux during years with average and high rainfall, although they represent only 9 percent of the total area. The UM Basin contributed about 6 percent or $8,000,000 \mathrm{~kg}$ of the TP load of $136,500,000 \mathrm{~kg}$ from the MAR Basin, which is similar to the percentage of the area it represents. The TP load computed by Goolsby and Battaglin (2000) at the Mississippi River at Clinton, Iowa, is slightly less than that computed in this study of $9,030,000 \mathrm{~kg}$ for the same years.

The size of the hypoxic zone in the Gulf has been shown to be directly related to the TN flux from the MAR Basin (Scavia and others, 2003). Rabalais and others (2002) concluded that almost a three-fold increase in TN load to the Gulf has driven the long-term increase in hypoxia since the middle of the last century. To determine how the changes in the annual loads of TN and TP computed from the study area are related to changes in annual loads entering the Gulf, the long-term annual loadings at the Mississippi River at Clinton, Iowa, from this study were compared to total load estimated from the MAR Basin by the Aulenbach and others (2007).

The long-term annual TN and TP loads at the Mississippi River at Clinton, Iowa, are compared with those estimated from the MAR Basin in figure 32. Data from Aulenbach and others (2007) demonstrate a slight decrease in TN loads from the MAR Basin from 1980 to 2004. Although the TN load at Clinton, Iowa, represents only about 10 percent of the total load from the MAR Basin, the loads at Clinton, Iowa, are strongly correlated to those estimated from the MAR Basin. Annual variability in the TN loads at Clinton, Iowa, describe about 57 percent of the variance in the loads estimated by simple correlation analysis (Aulenbach and others, 2007). The loads estimated at Clinton, Iowa, indicate that the decrease in TN loads from 1980 to 2004 in the data from Aulenbach and others (2007) is not a long-term trend but rather a short-term decline after increasing from 1975 to about 1985.

Data from Aulenbach and others (2007) demonstrate no trends in TP loads from the MAR Basin from 1980 to 2004. The TP loads from Clinton, Iowa, represent a smaller proportion of the loads from the MAR Basin than for TN and result in poorer correlation between TP loads than between TN loads. Annual variability in the TP loads at Clinton, Iowa, describe only about 10 percent of the variance in the loads estimated by Aulenbach and others (2007), estimated by simple correlation analysis. The loads estimated at Clinton, Iowa, also indicate no long-term trend in TP loads. 


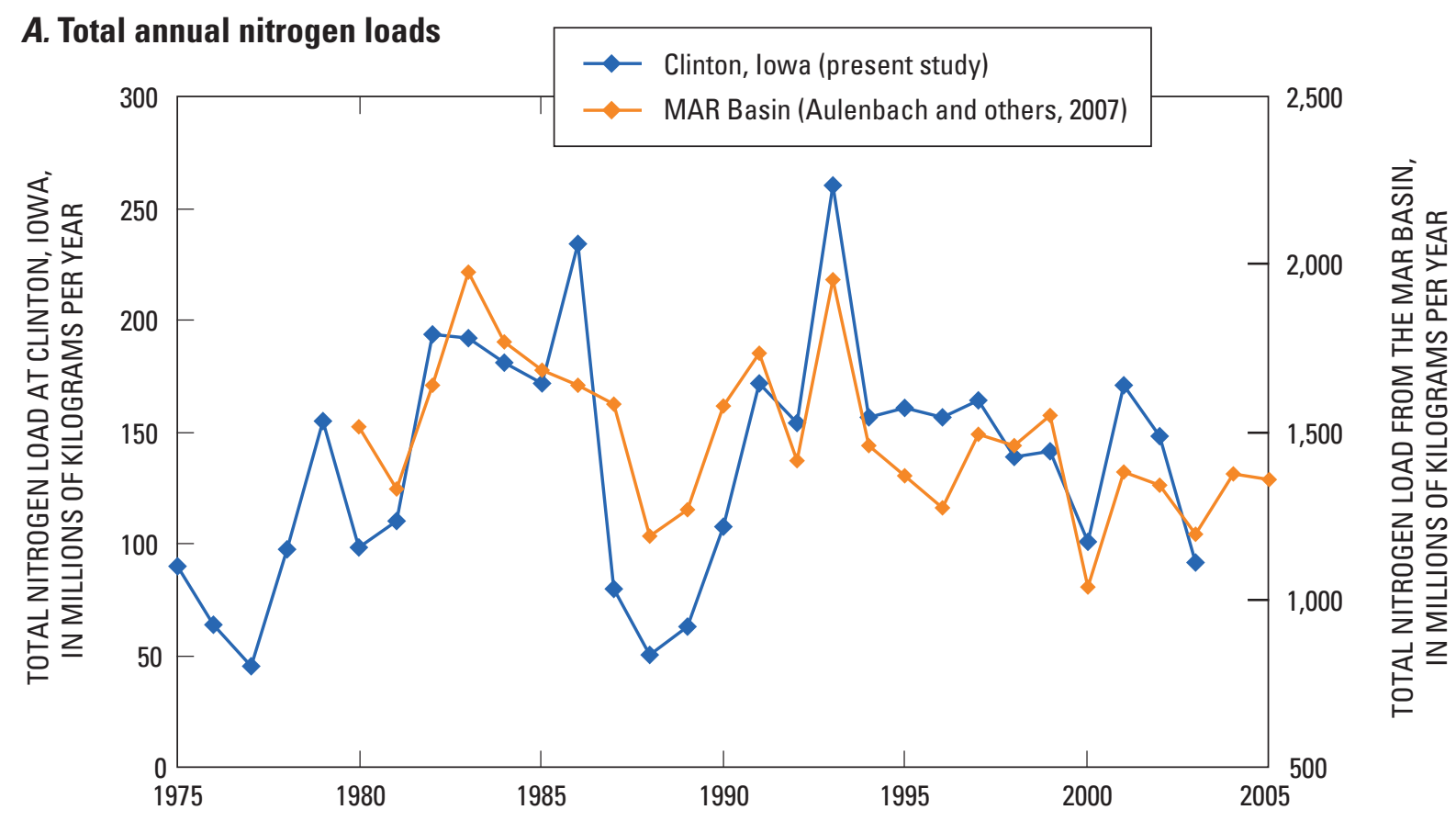

\section{B. Total annual phosphorus loads}

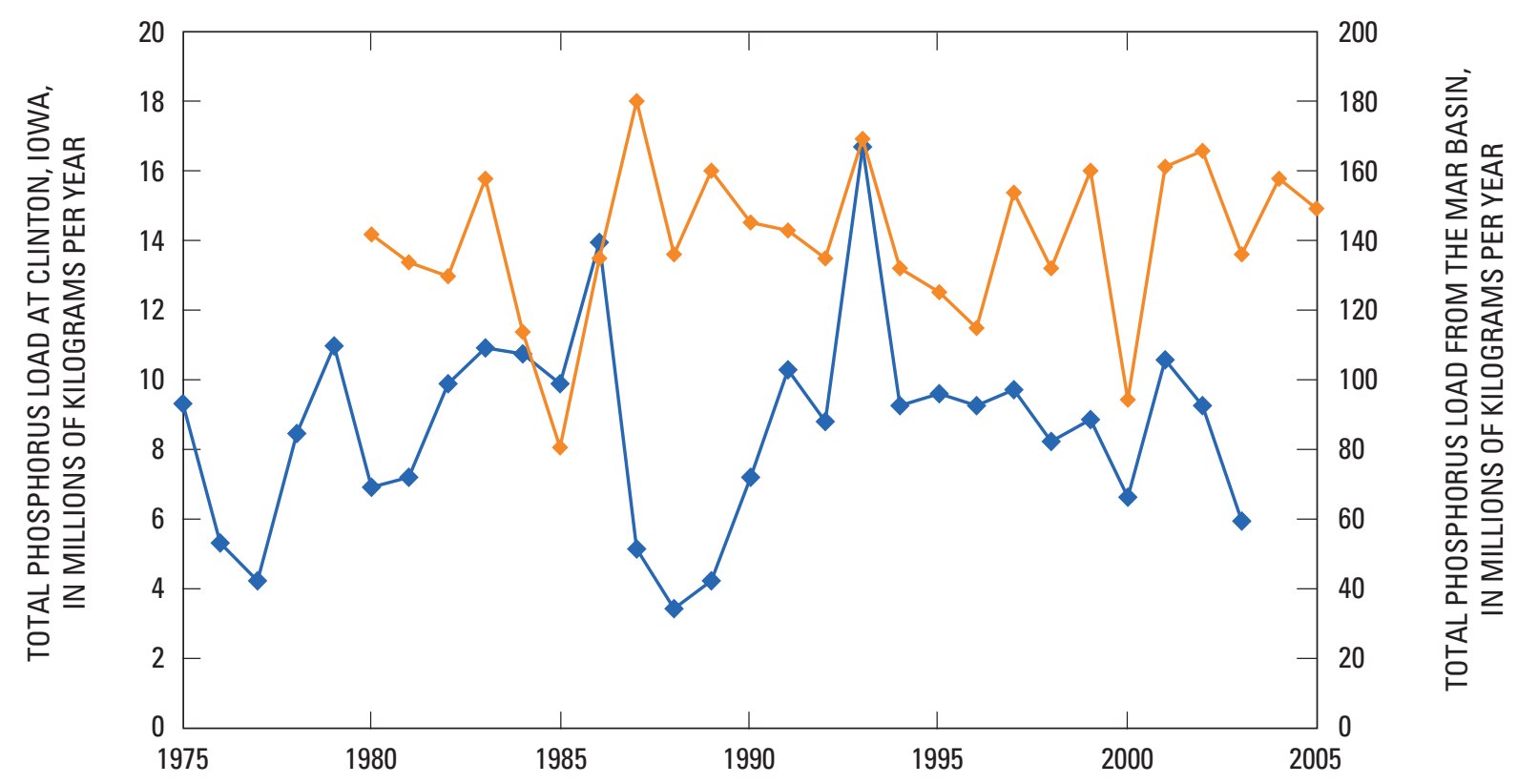

Figure 32. Total annual $\boldsymbol{A}$, nitrogen and $\boldsymbol{B}$, phosphorus loads at the Mississippi River at Clinton, lowa (site with the largest drainage area in this study) and from the entire Mississippi/Atchafalaya River (MAR) Basin from 1975 to 2005 as estimated in this study and by Aulenbach and others (2007). 


\section{Summary}

Elevated nutrient and suspended-sediment concentrations are two of the most common stressors or contaminants affecting streams throughout the United States. The elevated concentrations in rivers and streams can result in the overgrowth of benthic algae in shallow areas and areas with fast current and in an overabundance of phytoplankton and macrophytes in deep areas with slow current. High algal and macrophyte biomass, in turn, can cause severe diurnal fluctuations in dissolved oxygen and $\mathrm{pH}$ because of biotic production and respiration and can generate harmful organic materials when they die. Excessive transport of nutrients also has been linked to eutrophication of downstream lakes and impoundments, outbreaks of Pfiesteria in bays and estuaries in various Gulf and Mid-Atlantic States, and hypoxia in the Gulf of Mexico. Suspended sediment reduces clarity in streams and affects sight-feeding fish. Suspended sediment also interferes with water-treatment processes and recreational uses of streams. Excessive siltation can bury and suffocate fish eggs and bottom-dwelling organisms. In addition to instream effects, excessive sediment loading causes sedimentation problems in many downstream lakes and harbors and water-clarity problems in nearshore areas.

As a result of the Clean Water Act and subsequent regulations, many actions have been taken to reduce nutrient and suspended-sediment concentrations and the amount of nutrients and sediment transported in streams. It is important to assess how nutrient and suspended-sediment concentrations and loads in streams have changed in recent years to determine if these actions have been successful. A focus of this study was on flow-adjusted trends in concentrations, which reflect anthropogenic changes in the basin and are not the result of changes in climatic factors.

The study area comprises four major river basins: Upper Mississippi, Ohio, Red, and Great Lakes River Basins. The Upper Mississippi River Basin is defined as the Mississippi River and its tributaries upstream from the confluence with the Ohio River, excluding the Missouri River. The Ohio River Basin includes the Allegheny and Monongahela Rivers, and the Ohio River and its tributaries except the Tennessee River. The Red River Basin includes all rivers in the United States that drain northward to Lake Winnipeg and Hudson Bay, including the Red River of the North, the Souris River, and the Rainy River. The Great Lakes Basin includes all streams in the United States draining into the Great Lakes upstream from Montreal, Canada. Lake Michigan was joined with the Illinois River (Upper Mississippi River Basin) through construction of the Chicago Sanitary and Ship Canal in 1900, a project engineered to reverse the streamflow of the Chicago River in order to divert Chicago wastewaters into the Upper Illinois River and away from the historic receiving water of Lake Michigan.

Flow-adjusted (FA) and overall (OA) trends in concentrations and trends in loads were computed for total nitrogen (TN), dissolved ammonia (NH4), total organic plus ammonia
(Kjeldahl; KJN), dissolved nitrite plus nitrate (NO2NO3), total phosphorus (TP), dissolved phosphorus (DP), total suspended material (SMAT), and total suspended sediment (SS) at selected sites in the study area. Only sites that had at least 10 years of data for at least one constituent from 1993 to 2004, at least 60 samples, and streamflow data from a gage or a nearby gage with a drainage-area ratio ranging from 0.9 to 1.1 were selected for trend analyses. The base period from 1993 to 2004 was selected because it is relevant to current conditions and represents the period since the beginning of the National Water-Quality Assessment Program of the U.S. Geological Survey. For the final trend analysis in the base period, only 49 sites met the criteria. The sites are divided among the three different climatic parts of the study area, the western, central, and eastern parts. Eight of the sites were in the western part, 31 sites were in the central part, and 10 sites were in the eastern part of the study area.

From 1993 to 2004, FA trends in TN at 19 of the 24 sites that had sufficient data for analysis showed a tendency toward increasing concentrations. The 19 sites with increasing TN concentrations were distributed throughout the entire study area; however, only 8 of these sites had significant upward trends, and they were in the central part of the study area. These upward FA trends indicate that the effects of anthropogenic activities are continuing to increase in these areas and are contributing additional TN to the streams. Only two of the five sites with a downward tendency in concentrations had significant trends. The patterns in these FA trends in TN concentrations are similar to the changes in fertilizer nitrogen applications. The similarity in the patterns of these changes indicates a broad regional association between FA trends in $\mathrm{TN}$ concentrations and fertilizer applications. However, the significant upward FA trends in TN concentrations at five agricultural sites and upward trends at several of the others indicate that efforts to reduce runoff from agricultural lands have not been universally successful. At least two reasons account for that lack of success - the first is that local benefits do not necessarily translate to basinwide benefits, and the second is that unregulated activities such as tile drainage may counteract any benefit from efforts to reduce agricultural runoff.

The OA trends in TN concentrations from 1993 to 2004 indicated a general tendency toward increasing concentrations at 16 of the 24 sites; however, only 3 of these sites had significant upward trends; 2 sites were in southern Wisconsin in the central part of the study area, and 1 site was in the western part of the study area. Of the eight sites with a tendency toward decreasing concentrations, only two sites had significant downward trends and they are the same two sites that had downward FA trends. The sites with downward trends in concentrations were scattered throughout the study area.

From 1993 to 2004, TN loads at 17 of the 24 sites that had sufficient data for analysis indicated a tendency toward decreasing loads. Most of the sites with a downward trend were in the central or western parts of the study area. Eight of these sites had significant downward trends in loads; most of those sites had significant downward trends in streamflow. 
The only exception was the site in the eastern North Dakota, which had a significant downward trend in loads and no trend in streamflow. Only one of the seven sites with an upward trend in TN loads had a significant trend.

The FA trends in NH4 concentrations had a widespread downward tendency from 1993 to 2004. Of the 36 sites that had sufficient streamflow and NH4 concentration data for trend analysis, 32 sites had a downward trend in concentrations. Of these 32 sites, 24 sites had significant downward trends (at $\mathrm{p}<0.10$ ). Only four sites had an upward FA trend in NH4 concentrations, of which only one site, Northrup Creek, N.Y. (0422026250), had a significant upward FA trend in concentrations; however, the magnitude of this upward trend was only $0.002 \mathrm{mg} / \mathrm{L} / \mathrm{yr}$. The widespread, downward trends in NH4 concentrations for the trend sites indicate that some of the goals of the Clean Water Act are being met. There is, regionally, good agreement between FA trends in NH4 concentrations and changes in manure nitrogen, except in the farthest western part of the study area.

The OA trends in NH4 concentrations from 1993 to 2004 were similar to those of the FA trends. The OA trends in NH4 concentrations at 32 of the 36 sites that had sufficient data showed a general tendency toward decreasing concentrations, and the downward trends were statistically significant $(p<0.10)$ at 23 of these sites. Of the remaining four sites with upward OA trends in concentrations, the only site with a significant trend was again Northrup Creek, N.Y.

From 1993 to 2004, NH4 loads at 32 of the 36 sites that had sufficient data for analysis indicated a tendency toward decreasing loads. These sites were distributed across all three parts of study area. Twenty-six of these sites had significant downward trends in loads $(\mathrm{p}<0.10)$, and most of these sites had significant downward trends in both FA concentrations and streamflow.

The FA trends in KJN concentrations from 1993 to 2004 showed no distinct spatial pattern. Of the 36 sites that had sufficient streamflow and KJN concentration data for analysis, 17 sites had downward trends, and 19 sites had upward trends in FA concentrations. Seven sites had significant downward trends, and six sites had significant upward FA trends. The increase in human population and apparent decrease in animal manure production are competing factors that confound the interpretation of trend in KJN. Other confounding factors are the changes in treatments of those human and animal wastes.

When the OA trends in KJN concentrations from 1993 to 2004 were examined, no distinct spatial patterns were evident; however, the tendencies and statistical results were somewhat different than those of the FA trends. The differences in the results of the FA and OA trend analyses were attributable to differences in the trends in streamflow. Of the 36 sites that had sufficient streamflow and KJN concentration data for analysis, 18 sites had downward trends, and 18 sites had upward trends in KJN concentrations. Of these, nine sites had significant downward trends and six sites had significant upward trends $(\mathrm{p}<0.10)$.
The KJN loads from 1993 to 2004 had a downward trend at 30 sites and an upward trend at 6 sites, of the 36 sites that had sufficient data for analysis. The sites with downward trends in KJN loads were distributed across all three parts of study area; three of the six sites with upward trends were in the eastern part of the study area. Thirteen of the sites with downward trends in loads had significant trends, whereas only one of the six sites with upward trends in loads had a significant trend $(\mathrm{p}<0.10)$.

The FA trends in NO2NO3 concentrations from 1993 to 2004 showed no distinct spatial pattern. Of the 29 sites that had sufficient streamflow and $\mathrm{NO} 2 \mathrm{NO} 3$ concentration data for analysis, 12 sites had downward trends, and 17 sites had upward trends in concentrations. Of these sites, three sitesone in North Dakota, one in Illinois, and one in Indiana-had significant downward trends, and four sites - one in Iowa, one in Illinois, and two in Wisconsin - had significant upward trends $(\mathrm{p}<0.10)$. Some general agreement exists between the FA trends in NO2NO3 concentrations and the change in nitrogen fertilizer application. The small changes in the forested sites in northern Wisconsin are consistent with the changes in atmospheric deposition of nitrogen.

When the $\mathrm{OA}$ trends in $\mathrm{NO} 2 \mathrm{NO} 3$ concentrations from 1993 to 2004 were examined, no distinct spatial patterns were evident; however, tendencies and trend results were somewhat different than those of the FA trends. These differences in the results of the FA and OA trend analyses are attributable to differences in streamflow trends. Of the 29 sites that had sufficient streamflow and $\mathrm{NO} 2 \mathrm{NO} 3$ concentration data for analysis, 13 sites had downward trends, and 16 sites had upward trends in concentrations. Of these sites, four sites had significant downward trends, and three sites had significant upward trends $(\mathrm{p}<0.10)$.

Of the 29 sites that had sufficient data from 1993 to 2004 for analysis, 16 sites had downward trends, and 13 sites had upward trends in NO2NO3 loads. Seven of the sites with downward trends in loads had significant trends, whereas only one of the 12 sites with upward trends in loads had a significant trend $(\mathrm{p}<0.10)$.

From 1993 to 2004, FA trends in TP concentrations at 24 of the 40 sites that had sufficient data for analysis were upward. The 24 sites that had increasing TP concentrations were distributed throughout the entire study area; however, most of these sites were in the central part of the study area and the eastern side of the western part. Twelve of these 24 sites had significant upward trends $(\mathrm{p}<0.10)$. These upward FA trends indicate that the effects of anthropogenic activities are continuing to increase in these areas and are contributing additional TP to the streams. Downward FA trends in concentrations at 7 of the 16 sites were significant $(p<0.10)$ and indicate that the effects of anthropogenic activities are decreasing. Changes in the amount of phosphorus fertilizer use are consistent with FA trends in TP concentrations at four sites (04073468, 05427948, 054310157, and 0422026250), all of which had downward trends. However, phosphorus fertilizer use was negatively associated with the FA trends in 
TP concentrations at six sites $(\mathrm{p}<0.05)$, which contradicts its use in explaining the observed trend at these sites. The lack of a strong association between phosphorus fertilizer use and FA trends in TP concentrations indicates that other factors are important in determining TP concentrations in streams.

The OA trends in TP concentrations from 1993 to 2004 showed a general tendency toward increasing concentrations at 21 of the 41 sites; however, the upward trends were significant at only 7 of these sites $(\mathrm{p}<0.10)$. Of the 20 sites with a downward trend, only 7 sites had significant trends. The sites with upward or downward trends were scattered throughout the study area.

From 1993 to 2004, trends in TP loads at 30 of the 41 sites that had sufficient data for analysis were downward. Twelve of these sites, all within the central and eastern parts of the study area, had significant $(\mathrm{p}<0.10)$ downward trends in loads. Most of these sites had significant downward trends in streamflow. The upward trends were statistically significant $(\mathrm{p}<0.10)$ at only 2 of the 11 sites. A comparison of the trends in loads and FA trends in concentrations indicates that most of the trends in loads were driven primarily by streamflow rather than changes in concentration, except in southern Wisconsin where trends in both streamflow and concentrations were significantly downward.

The FA trends in DP concentrations from 1993 to 2004 showed mixed regional tendencies; however, DP concentrations consistently decreased at all of sites in the eastern part of the study area. Of the 35 sites that had sufficient streamflow and DP concentration data for analysis, 23 sites had downward trends in concentrations. Of these sites, 12 sites had significant downward trends, and the trends at all 7 of the sites in the eastern part of the study area were significant. Five sites, all in the central part of the study area, had significant upward trends $(p<0.10)$. A comparison of the patterns of FA trends in DP concentrations with those of nonpoint phosphorus inputs indicates fairly good regional agreement indicating that the reduction in fertilizers and manure east of the Mississippi River influences observed trends in DP concentrations. Some discrepancies exist in Illinois, but those probably are caused by nonagricultural influences.

When the OA trends in DP concentrations from 1993 to 2004 were examined, spatial trends followed the same general pattern of decreasing concentrations in the eastern areas and increasing and decreasing concentrations in the central and western parts of the study area. Several differences between the FA and OA trend analyses were found for specific sites in the central part of the study area, where many more sites had significant downward OA trends than downward FA trends. These differences in the results of the FA and OA trend analyses are attributable to the significant trends in streamflow. Of the 35 sites that had sufficient streamflow and DP data for analysis, 26 sites had downward trends, and 8 sites had upward trends in concentrations. Of these sites, 15 sites had significantly downward trends, and 4 sites in Illinois had significant upward trends $(\mathrm{p}<0.10)$.
From 1993 to 2004, trends in DP loads at 32 of the 35 sites that had sufficient data for analysis were downward; trends at 15 of these sites were significant $(\mathrm{p}<0.10)$. Upward trends in DP loads at two of the three sites, all located in northern Illinois, were significant.

The FA trends in SMAT and SS concentrations from 1993 to 2004 showed distinct spatial patterns; concentrations tended to increase in Illinois and to decrease throughout most of Wisconsin, Iowa, and the eastern part of the study area. The main difference was that some of the downward trends observed for the SMAT data in Wisconsin and New York and upward trends in Illinois were not observed for SS data because most of these sites only had total suspended solids data. In addition, when the total suspended solids data were removed from the data from the Popple River in northern Wisconsin, the upward trend in SS became significant. Of the 42 sites that had sufficient streamflow and SMAT concentration data for analysis, 25 sites had downward trends, and 17 sites had upward trends in concentrations. Of these sites, 12 sites had significant downward trends and 5 sites had significant upward trends $(\mathrm{p}<0.10)$. Of the 22 sites that had sufficient streamflow and SS concentration data for analysis, 15 sites had downward trends, of which 7 trends were statistically significant, and 7 sites had upward trends in concentrations, of which 3 trends were statistically significant $(\mathrm{p}<0.10)$.

The spatial pattern in the OA trends in SMAT and SS concentrations generally was the same as that for the FA trends; however, several of the sites with non-significant trends, especially in Iowa, had significant downward OA trends $(\mathrm{p}<0.10)$. Of the 42 sites that had sufficient streamflow and SMAT concentration data for trend analysis, 30 sites had downward trends, and 12 sites had upward trends in concentrations. Of these sites, 18 sites had significant downward trends, and 5 sites had significant upward trends. The sites with significant upward trends in concentrations were in Illinois and North Dakota.

From 1993 to 2004, SMAT and SS loads indicated a tendency toward decreasing loads. SMAT loads had downward trends at 36 sites and upward trends at 6 sites. Nineteen of the 22 sites had a downward trend in SS loads. Twenty of the sites, throughout most of the study area, with a downward trend in SMAT loads had significant trends, and three sites in northern Illinois and North Dakota had a significant upward trend in loads. Once again the pattern in the load trends resembles that for streamflow.

Changes in TN, TP, and SMAT loads were examined from 1975 to 2003 at six sites. These changes were examined to provide a longer term perspective on the data examined from 1993 to 2004. The long-term, nonmonotonic trends were described by LOESS smoothing. The statistical significance of those trends cannot be determined; however, the long-term changes for annual streamflow and load data indicate that the monotonic trends from 1993 to 2004 should not be extrapolated backward in time. 
Most of the changes in long-term loads are directly caused by the change in streamflow rather than a change in nutrient or sediment concentrations. The long-term changes in concentrations were much smaller than the long-term changes in streamflow. This results in the long-term changes in loads directly resembling the long-term changes in streamflow. The most prominent example of this is in data for streamflow and TN, TP, and SMAT loads at the Souris River, N. Dak., from 1975 to 2003.

The insights provided by examining trends at sites that have a long history of streamflow and water-quality monitoring demonstrate the value of establishing and maintaining a long-term streamflow and water-quality monitoring network for planning purposes in the United States, especially because current thought (2007) is that global warming could lead to large-scale changes in the climate of North America during the 21 st century. The strong influence of streamflow on nutrient and sediment loads can result in long-term trends caused by changes in climate rather than changes caused by anthropogenic changes. In general, such large-scale regional changes in climate and associated hydrology could necessitate modifications to infrastructure if changes occur in lake levels, flood crests, and flood frequency, or if lesser future rainfall in some areas places unanticipated strains on water use and sewerages.

\section{References Cited}

Akaike, H., 1974, A new look at statistical model identification: IEEE Transactions on Automatic Control AU-19, p. 716-722.

Aulenbach, B.T., Buxton, H.T., Battaglin, W.A., and Coupe, R.H., 2007, Streamflow and nutrient fluxes of the Mississippi-Atchafalaya River Basin and subbasins for the period of record through 2005: U.S. Geological Survey Open-File Report 2007-1080, accessed February 10, 2009, at http://pubs.usgs.gov/of/2007/1080/.

Baker, N.T., Stone, W.W., Frey, J.W., and Wilson, J.T., 2007, Water and agricultural-chemical transport in a Midwestern, tile-drained watershed-Implications for conservation practices: U.S. Geological Survey Fact Sheet 2007-3084, 4 p.

Baker, N.T., Stone, W.W., Wilson, J.T., and Meyer, M,T., 2006, Occurrence and transport of agricultural chemicals in Leary Weber Ditch Basin, Hancock County, Indiana, 2003-04: U.S. Geological Survey Scientific Investigations Report 2006-5251, 44 p.

Clifford, John, Dulaney, R.A., and Olsen, M.V., 1993, Using the EPA RF3 database to facilitate mandated water quality reporting: U.S. Environmental Protection Agency, Office of Research and Development, November 1993.
Cohn, T.A., 2005, Estimating contaminant loads in rivers-An application of adjusted maximum likelihood to type 1 censored data: Water Resources Research, v. 41, no. 7, 13 p., W07003, doi:10.1029/2004WR003833.

Cohn, T.A., Caulder, D.L., Gilroy, E.J., Zynjuk, L.D., and Summers, R.M., 1989, The validity of a simple statistical model for estimating fluvial constituent loads - An empirical study involving nutrient loads entering Chesapeake Bay: Water Resources Research, v. 28, no. 9, p 2,353-2,363.

Corsi, S.R., Walker, J.F., Wang, L., Horwatich, J.A., and Bannerman, R.T., 2005, Effects of best-management practices in Otter Creek in the Sheboygan River Priority Watershed, Wisconsin, 1990-2002: U.S. Geological Survey Scientific Investigations Report 2005-5009, 26 p.

Dodds, W.K., and Welch, E.B., 2000, Establishing nutrient criteria in streams: Journal of North American Benthological Society, v. 19, p. 186-196.

Farnsworth, R.K., Thompson, E.S., and Peck, E.L., 1982, Evaporation atlas for the contiguous 48 United States: Washington, D.C., National Weather Service, National Oceanographic and Atmospheric Administration Technical Report NWS 33, 26 p.

Gebert, W.A., Graczyk, D.J., and Krug, W.R., 1987, Average annual runoff in the United States, 1951-80: U.S. Geological Survey Hydrologic Atlas 710, 1 sheet, scale 1:2,000,000.

Geolytics, 2006, Online data, accessed November 21, 2007, at http://www.geolytics.com/census2000.htm

Goolsby, D.A., and Battaglin, W.A., 2000, Nitrogen in the Mississippi Basin-Estimating sources and predicting flux to the Gulf of Mexico: U.S. Geological Survey Fact Sheet $135-00,6 \mathrm{p}$.

Goolsby, D.A., Battaglin, W.A., Lawrence, G.B., Artz, R.S., Aulenbach, B.T., Hooper, R.P., Keeney, D.R., and Stensland, G.J., 1999, Flux and sources of nutrients in the Mississippi-Atchafalaya River Basin-Topic 3 report for the integrated assessment on hypoxia in the Gulf of Mexico: Silver Spring, Md., National Oceanographic and Atmospheric Administration Coastal Ocean Office, NOAA Coastal Ocean Program Decision Analysis Series no. 17, $130 \mathrm{p}$.

Gray, J.R., Glysson, G.D., Turcios, L.M., and Schwarz, G.E., 2000, Comparability of suspended-sediment concentration and total suspended solids data: U.S. Geological Survey Water-Resources Investigations Report 00-4191, 14 p.

Hall, D.W., 2006, Surface water quantity and quality of the northern Milwaukee River, Cedar Creek, and Root River basins, Wisconsin, 2004: U.S. Geological Survey Open-File Report 2006-1121, 52 p. 
Helsel, D.R., 2005, Insider censoring-Distortion of data with nondetects: Human and Ecological Risk Assessment, v. 11, p. 1,127-1,137.

Helsel, D.R., and Hirsch, R.M., 2002, Statistical methods in water resources: U.S. Geological Survey Techniques of Water-Resources Investigations 04-A3, 523 p.

Hodgkins, G.A., Dudley, R.W., and Aichele, S.S., 2007, Historical changes in precipitation and streamflow in the U.S. Great Lakes Basin, 1915-2004: U.S. Geological Survey Scientific Investigations Report 2007-5118, 31 p.

Horne, J.E., 2000, Rural communities and CAFOs-New ideas for resolving conflict: Poteau, Okla., Kerr Center for Sustainable Agriculture, accessed February 22, 2008, at http://www.kerrcenter.com/publications/CAFO.pdf

Insightful, 2005, S-PLUS 7 for Windows User's Guide: Seattle, Wash., Insightful Corporation, 664 p.

Langland, M.J., 1992, Atmospheric deposition of ammonia from open manure-storage lagoons in south central Pennsylvania: The Environmental Professional, v. 14, p. 28-37.

Lins, H.F., 2005, Streamflow trends in the United States...from the National Streamflow Information Program: U.S. Geological Survey Fact Sheet 2005-3017, 4 p.

Matson, Pamela, Lohse, K.A., and Hall, S.J., 2002, The globalization of nitrogen deposition-Consequences for terrestrial ecosystems: AMBIO, A Journal of the Human Environment, v. 31, p. 88-96.

Midwestern Regional Climate Center, 2006, Online data, accessed June 1, 2006, at http://mcc.sws/uius.edu/.

Miltner, R.J., and Rankin, E.T., 1998, Primary nutrients and the biotic integrity of rivers and streams: Freshwater Ecology, v. 40, p. 145-158.

Mosteller, Frederick, and Tukey, J.W., 1977, Data analysis and regression-A second course in statistics: Reading, Mass., Addison Wesley, 588 p.

Myers, D.N., Metzker, K.D., and Davis, S., 2000, Status and trends in suspended-sediment discharges, soil erosion, and conservation tillage in the Maumee River Basin-Ohio, Michigan, and Indiana: U.S. Geological Survey WaterResources Investigations Report 00-4091, 38 p.

National Climatic Data Center, 2002, Climatology of the United States No. 81-Monthly normals of temperature, precipitation, and heating and cooling degree days, 1971-2000: Asheville, N.C., National Climatic Data Center, accessed November 21, 2007, at http://www.ncdc.noaa.gov/ oa/climate/normals/usnormals.html
Rabalais, N.N., Turner, R.E., and Scavia, D., 2002, Beyond science into policy - Gulf of Mexico hypoxia and the Mississippi River: BioScience, v. 52, p. 129-142.

Robertson, D.M., Saad, D.A., and Heisey, D.M., 2006, Present and reference concentrations and yields of suspended sediment in streams in the Great Lakes region and adjacent areas: U.S. Geological Survey Scientific Investigations Report 2006-5066, 35 p.

Ruddy, B.C., Lorenz, D.L., and Mueller, D.K., 2006, Countylevel estimates of nutrient inputs to the land surface of the conterminous United States, 1982-2001: U.S. Geological Survey Scientific Investigations Report 2006-5012, 17 p.

Runkel, R.L., Crawford, C.G., and Cohn, T.A., 2004, Load estimator (LOADEST) - A FORTRAN program for estimating constituent loads in streams and rivers: U.S. Geological Survey Techniques and Methods 4-A5, 75 p.

Ruppel, James, Sullivan, John, Schreiber, Ken, and Galarneau, Steve, 2006, Wisconsin's long term trend water quality monitoring program for rivers: Wisconsin Department of Natural Resources, Bureau of Watershed Management, River Long Term Trends Work Group, November 2006, 47 p., accessed July 13, 2007, at http://dnr.wi.gov/org/water/ monitoring/reports/LTT_AnnualReport_11-30-06.pdf

Scavia, Donald, Rabalais, N.N., Turner, R.E., Justic, D., and Wiseman, W., Jr., 2003, Predicting the response of Gulf of Mexico hypoxia to variations in Mississippi River nitrogen load: Limnology and Oceanography, v. 48, p. 951-956.

Schneider, M.A., Lutz, M.A., and others, 2004, Waterresources-related information for the Milwaukee Metropolitan Sewerage District Planning Area, Wisconsin, 1970-2002: U.S. Geological Survey Water-Resources Investigations Report 03-4240, 288 p.

Schwarz, G.E., Hoos, A.B., Alexander, R.B., and Smith, R.A., 2006, SPARROW-MOD_-User documentation for the SPARROW surface water-quality model: U.S. Geological Survey Techniques and Methods, book 6, section B, Surface water, chapter 3 (6-B3), 248 p.

Seaber, P.R., Kapinos, E.P., and Knapp. G.L., 1984, State hydrologic unit maps: U.S. Geological Survey Open-File Report 84-708, 198 p.

Solomon, S., Qin, D., Manning, M., Marquis, M., Averyt, K., Tignor, M.M.B., Miller, H.L., Jr., and Chen, Z., eds., 2007, Climate change 2007-The physical science basis - Contribution of Working Group I to the Fourth Assessment Report of the Intergovernmental Panel on Climate Change: IPCC WG1 AR4 Report, accessed July 7, 2008, at http://ipcc-wg1.ucar.edu/wg1/wgl-report.html 
Sousounis, P.J., and Bisanz, J.M., eds., 2000, Preparing for a changing climate-The potential consequences of climate variability and change-Great Lakes overview: Ann Arbor, Mich., University of Michigan, 106 p., accessed August 1, 2007, at http://www.geo.msu.edu/glra/assessment/ assessment.html

Sprague, L.A., Clark, M.L., Rus, D.L., Zelt, R.B., Flynn, J.F., and Davis, J.V., 2006, Nutrient and suspended-sediment trends in the Missouri River Basin, 1993-2003: U.S. Geological Survey Scientific Investigations Report 2006-5231, $89 \mathrm{p}$.

Stoddard, J.L, Kahl, J.S., Deviney, F.A., DeWalle, D.R., Driscoll, C.T., Herlihy, A.T., Kellogg, J.H., Murdoch, P.S., Webb, J.R., and Webster, K.E., 2003, Response of surface water chemistry to the Clean Air Act Amendments of 1990: U.S. Environmental Protection Agency, EPA 620/R-03/001, $78 \mathrm{p}$.

Strock, J.S., Dell, C.J., and Schmidt, J.P., 2007, Managing natural processes in drainage ditches for nonpoint source nitrogen control: Journal of Soil and Water Conservation, v. 62 , p. $188-196$.

Sullivan, J., Stoltenberg, D., Manoyan, S., Huang, J., Zdanowicz, R., and Redmon, W., 2002, Upper Mississippi River water quality assessment report: USEPA Upper Mississippi River Conservation Committee, Water Quality Technical Section, 198 p., accessed October 1, 2006, at http://www.epa.gov/r5water/pdf/umr_wqa_full.pdf

The Encyclopedia of Saskatchewan, 2008, Souris River, accessed March 7, 2008, at http://esask.uregina.ca/entry/ souris_river.html

U.S. Army Corps of Engineers, 2004, Iowa Cedar River Basin, accessed October 1, 2006, at http://www.mvr.usace.army. mil/PublicAffairsOffice/iowawrb04/iowacedarriverbasin. html

U.S. Environmental Protection Agency, 1996, National water quality inventory - 1996 Report to Congress: Office of Water, EPA-R-97-008, 527 p.

U.S. Environmental Protection Agency, 1998, National strategy for the development of regional nutrient criteria: Office of Water, EPA-822-R-98-002, 47 p.

U.S. Environmental Protection Agency, 2000, Ambient water quality criteria recommendations - Rivers and streams in nutrient ecoregion VII: Office of Water, EPA822-B-00-018 [variously paged].

U.S. Environmental Protection Agency, 2002, Nitrogen-Multiple and regional impacts: Clean Air Market Programs, EPA-430-R-01-006, 42 p., accessed February 1, 2008, at http://www.epa.gov/airmarket/resource/docs/nitrogen.pdf
U.S. Environmental Protection Agency, 2005, Protecting water quality from agricultural runoff, EPA-841-F-05-001, 2 p.,

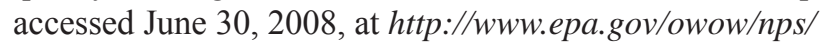
Ag_Runoff_Fact_Sheet.pdf

U.S. Environmental Protection Agency, 2006a, Laws and regulations, accessed October 1, 2006, at http://www.epa.gov/r5water/cwa.htm

U.S. Environmental Protection Agency, 2006b, Milwaukee Estuary Area of Concern, accessed October 1, 2006, at http://www.epa.gov/glnpo/aoc/milwaukee.html

U.S. Environmental Protection Agency, 2006c, Maumee River Area of Concern, accessed October 1, 2006, at http://www.glc.org/demo/aoc/maumee.html

U.S. Environmental Protection Agency, 2007, Maumee River Area of Concern: U.S. Environmental Protection Agency Great Lakes National Program Office, accessed January 8, 2007, at http://www.epa.gov/glnpo/aoc/maumee.html

U.S. Geological Survey, 1998, National Water Information System (NWIS): U.S. Geological Survey Fact Sheet FS-027-98, 2 p.

U.S. Geological Survey, 2000, National Land Cover Dataset: U.S. Geological Survey Fact Sheet 1008-00, accessed December 29, 2005, at http://erg.usgs.gov/isb/pubs/ factsheets/fs10800.html

U.S. Geological Survey, 2006a, Nutrient fluxes for the Mississippi River Basin and sub-basins, accessed September 1, 2006, at http://toxics.usgs.gov/hypoxia/mississippi/nutrient_ flux_yield_est.html

U.S. Geological Survey, 2006b, Souris River bibliography, accessed October 1, 2006, at http://nd.water.usgs.gov/pubs/ key/sourisriver.html

Vecchia, A.V., 2000, Water-quality trend analysis and sampling design for the Souris River, Saskatchewan, North Dakota, and Manitoba: U.S. Geological Survey WaterResources Investigations Report 00-4019, 77 p., accessed August 15, 2007, at http://nd.water.usgs.gov/pubs/wri/ wri004019/index.html

Vecchia, A.V., 2003a, Relation between climate variability and stream water quality in the continental United States: Hydrological Science and Technology, v. 19, no. 1-4, p. 77-98.

Vecchia, A.V., 2003b, Water-quality trend analysis and sampling design for streams in North Dakota, 1971-2000: U.S. Geological Survey Water-Resources Investigations Report 03-4094, 73 p., accessed August 15, 2007, at http://nd.water.usgs.gov/pubs/wri/wri034094/index.html 
Vecchia, A.V., 2005, Water-quality trend analysis and sampling design for streams in the Red River of the North Basin, Minnesota, North Dakota, and South Dakota, 1970-2001: U.S. Geological Survey Scientific Investigations Report 2005-5224, 54 p., accessed August 15, 2007 , at http://pubs.water.usgs.gov/sir2005-5224/.

Voss, Karen, and Beaster, Sarah, 2001, The state of Lower Chippewa Basin: Wisconsin Department of Natural Resources Publication WT-554-00, 115 p.

Welch, E.B., Quinn, J.M., and Hickey, C.W., 1992, Periphyton biomass related to point-source nutrient enrichment in seven New Zealand streams: Water Research, v. 26, p. 669-675.
Winterstein, T.A., and Lorenz, D.L., 2007, Relation between precipitation and the 25 th percentile of June and September flows in streams in the Great Lakes, Ohio, and Upper Mississippi River Basins: U.S. Geological Survey Scientific Investigations Report 2007-5129, 22 p.

Wisconsin Department of Natural Resources, 2006, The Milwaukee River Basin, accessed October 1, 2006, at http:// www.dnr.wisconsin.gov/org/gmu/milw/milwflyer_801.pdf

Zipper, C.A., Holtzman, G., Darken, P., Thomas, P., Glidea, J., and Younos, T., 1998, Long-term trends in Virginia's waterways: Blacksburg, Va., Virginia Polytechnical Institute and State University, VWRRC Special Report No. SR11-1998 [variously paged]. 
82 Trends in the Upper Mississippi, Ohio, Red, and Great Lakes River Basins, 1975-2004

This page is intentionally blank. 

